\title{
Religie in een technologische cultuur
}

\author{
Citation for published version (APA):
}

van Well, M. D. J. (2021). Religie in een technologische cultuur: over de rol van het sacrale in de ontwikkeling van het gezondheidsportaal PAZIO. [, Maastricht University]. Maastricht University. https://doi.org/10.26481/dis.20211015mw

Document status and date:

Published: 01/01/2021

DOI:

10.26481/dis.20211015mw

Document Version:

Publisher's PDF, also known as Version of record

\section{Please check the document version of this publication:}

- A submitted manuscript is the version of the article upon submission and before peer-review. There can be important differences between the submitted version and the official published version of record.

People interested in the research are advised to contact the author for the final version of the publication, or visit the DOI to the publisher's website.

- The final author version and the galley proof are versions of the publication after peer review.

- The final published version features the final layout of the paper including the volume, issue and page numbers.

Link to publication

\footnotetext{
General rights rights.

- You may freely distribute the URL identifying the publication in the public portal. please follow below link for the End User Agreement:

www.umlib.nl/taverne-license

Take down policy

If you believe that this document breaches copyright please contact us at:

repository@maastrichtuniversity.nl

providing details and we will investigate your claim.
}

Copyright and moral rights for the publications made accessible in the public portal are retained by the authors and/or other copyright owners and it is a condition of accessing publications that users recognise and abide by the legal requirements associated with these

- Users may download and print one copy of any publication from the public portal for the purpose of private study or research.

- You may not further distribute the material or use it for any profit-making activity or commercial gain

If the publication is distributed under the terms of Article $25 \mathrm{fa}$ of the Dutch Copyright Act, indicated by the "Taverne" license above, 


\title{
RELIGIE IN EEN \\ TECHNOLOGISCHE CULTUUR
}

\author{
Over de rol van het sacrale in de ontwikkeling \\ van het gezondheidsportaal PAZIO
}

\section{PROEFSCHRIFT}

ter verkrijging van de graad van doctor aan de Universiteit Maastricht, op gezag van de Rector Magnificus, Prof. dr. Rianne M. Letschert volgens het besluit van het College van Decanen,

in het openbaar te verdedigen

op vrijdag 15 oktober 2021 om 14.00 uur 


\section{Promotores}

Prof. dr. ir. W. E. Bijker

Prof. dr. M. J. Verkerk

\section{Beoordelingscommissie}

Prof. dr. R. de Wilde (voorzitter)

Prof. dr. J. Hoogland (Universiteit Twente)

Prof. dr. B. Meyer (Universiteit Utrecht)

Prof. dr. T. E. Swierstra

Prof. dr. S.M.E. Wyatt

Dit proefschrift is mede mogelijk

gemaakt dankzij een financiële bijdrage van de Noaber Foundation. 


\section{President Joe once had a dream,}

The world held his hand, gave their pledge,

So he told them his scheme for a Saviour Machine.

They called it the Prayer, its answer was law,

Its logic stopped war, gave them food,

How they adored till it cried in its boredom:

'Please don't believe in me, please disagree with me,

Life is too easy, a plague seems quite feasible now,

Or maybe a war, or I may kill you all.

Don't let me stay, don't let me stay,

My logic says burn, so send me away,

Your minds are too green, I despise all I've seen,

You can't stake your lives on a Saviour Machine.' 
Toen sprak de HEERE tot Mozes:

'En zij moeten voor Mij een heiligdom maken, zodat Ik in hun midden kan wonen.

Volgens alles wat Ik u zal tonen,

een ontwerp van de tabernakel

en een ontwerp van al zijn voorwerpen,

zó moet u het maken.' 


\section{Inhoud}

INLEIDING

1.1 DE BLINDE VLEK IN DE TECHNOLOGISCHE CULTUUR: RELIGIE

1.2 SECUlarisatiE of tRANSFormatiE VAN RELIGIE?

1.3 TECHNOLOGISCHE CULTUUR

1.4 CASUS PAZIO

1.4.1 Periode 1: ontwikkelen concept en organisatie 
2.2.1 De invloed van technologie op religie

2.2.2 Noble over de invloed van religie op technologie

2.2.3 De grondmotieven van Dooyeweerd

2.2.4 Het sacrale bij Szerszynski

2.2.5 Het sublieme in een technologische cultuur

\subsection{PERSPECTIEVEN VOOR ONDERZOEK IN EEN}

TECHNOLOGISCHE CULTUUR

58

2.4 TRIPLE I MODEL - EEN PERSPECTIEF OP DE MODALITEITEN

VAN TECHNOLOGISCHE PRAKTIJKEN

58

2.4.1 Aspecten en individualiteitsstructuren

60

2.4.3 Identiteit, Interests en Idealen

2.5 SOCIAL CONSTRUCTION OF TECHNOLOGY - EEN PERSPECTIEF OP SOCIO-TECHNISCHE VERANDERING

2.5.1 Onderzoeksaanpak en theorie

2.5.2 Relevante sociale groepen en betekenisflexibiliteit

2.5.3 Stabilisatie

66

2.5.4 Technologisch frame

66

2.5.5 Promising technology

2.6 HET SACRALE - EEN CONSTRUCTIVISTISCH PERSPECTIEF

OP RELIGIE EN SAMENLEVING

2.6.1 Het fundamentele onderscheid: sacraal - profaan 
3.4.1 Een Patiëntgeoriënteerde Virtuele Zorginfrastructuur voor particuliere belangen

3.4.2 Subsidieaanvraag M\&ICT: PAZIO als doorbraakmachine voor systeemfalen 


\section{HET RITUALISEREN VAN DE}

4.1 INLEIDING

4.2 DE DEMONSTRATIE VAN PAZIO - EEN OOGGETUIGENVERSLAG

4.7 TWEEDE PAZIO-IMPLEMENTATIE POGING BIJ 
4.8.1 De keuze tussen twee scenario's: HIS- of Portaal-integratie

\section{DE DYNAMIEK VAN SOCIALE}

5.2 PERIODE 1: EEN GEMEENSCHAPPELIJK PLAN VOOR

HET PROJECT PAZIO

5.2.1 Verandering 1: de ideale richting vinden vanuit particuliere perspectieven

5.2.2 Stabilisatie 1: een ontluikende sacrale vorm rond de naam 
5.3 PERIODE 2: STEUN VOOR EEN OMNIPOTENT PORTAAL

EN DE ICONISCHE PATIËNT

214

5.3.1 Verandering 2: een missionaire gemeeschap op zoek naar

morele en materiele steun

214

5.3.2 Stabilisatie 2: mevrouw De Wolf en PAZIO vormen

de sacrale vorm

220

5. 4 PERIODE 3: HET PORTAAL IN DE PRAKTIJK

225

5.4.1 Verandering 3: profane strijd over sacrale zaken in de praktijk

225

5.4.2 Stabilisatie 3: rituelen voor de digitale behandelrelatie

231

5.5 MEER VERANDERING EN STABILISATIE

232

5.6 CONCLUSIES

233

5.6.1 De dynamiek van de veranderfase

234

5.6.2 De dynamiek van de verbindingsfase

235

5.6.3 De meerwaarde van de sacrale vorm

235

6.1 INLEIDING

6.2 DE TECHNOLOGISCHE CULTUUR IS EEN RELIGIEUZE CULTUUR

242

6.3 DE RICHTINGGEVENDE ROL VAN HET SACRALE IN DE

TECHNOLOGISCHE CULTUUR

243 
6.4 THEORIE VAN HET SACRALE IN EEN TECHNOLOGISCHE CULTUUR

6.4.1 SCOT en het sacrale

6.4.2 Sociale verbanden, narratieven en activiteiten

6.4.3 Sacrale vormen en dynamiek

254

6.5 HANDVATTEN VOOR ONDERZOEK VAN HET SACRALE IN EEN TECHNOLOGISCHE CULTUUR

6. 6 DE DRAAI NAAR HET SACRALE: INZICHTEN VOOR ONDERZOEK, INNOVATIE, RELIGIE EN DEBAT 
AFKORTINGEN

FIGUREN EN TABELLEN

DANKWOORD

327

CURRICULUM VITAE

331 



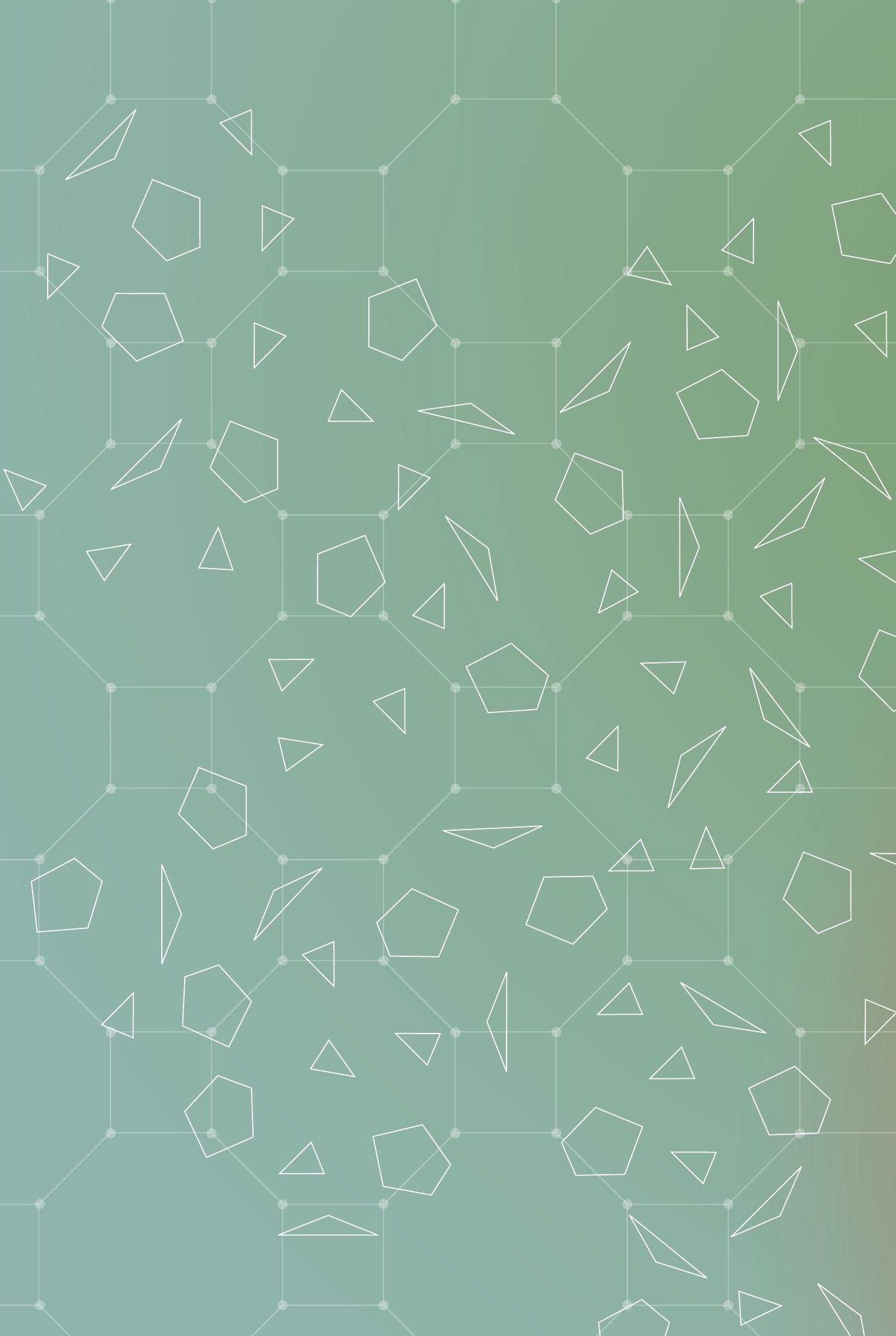





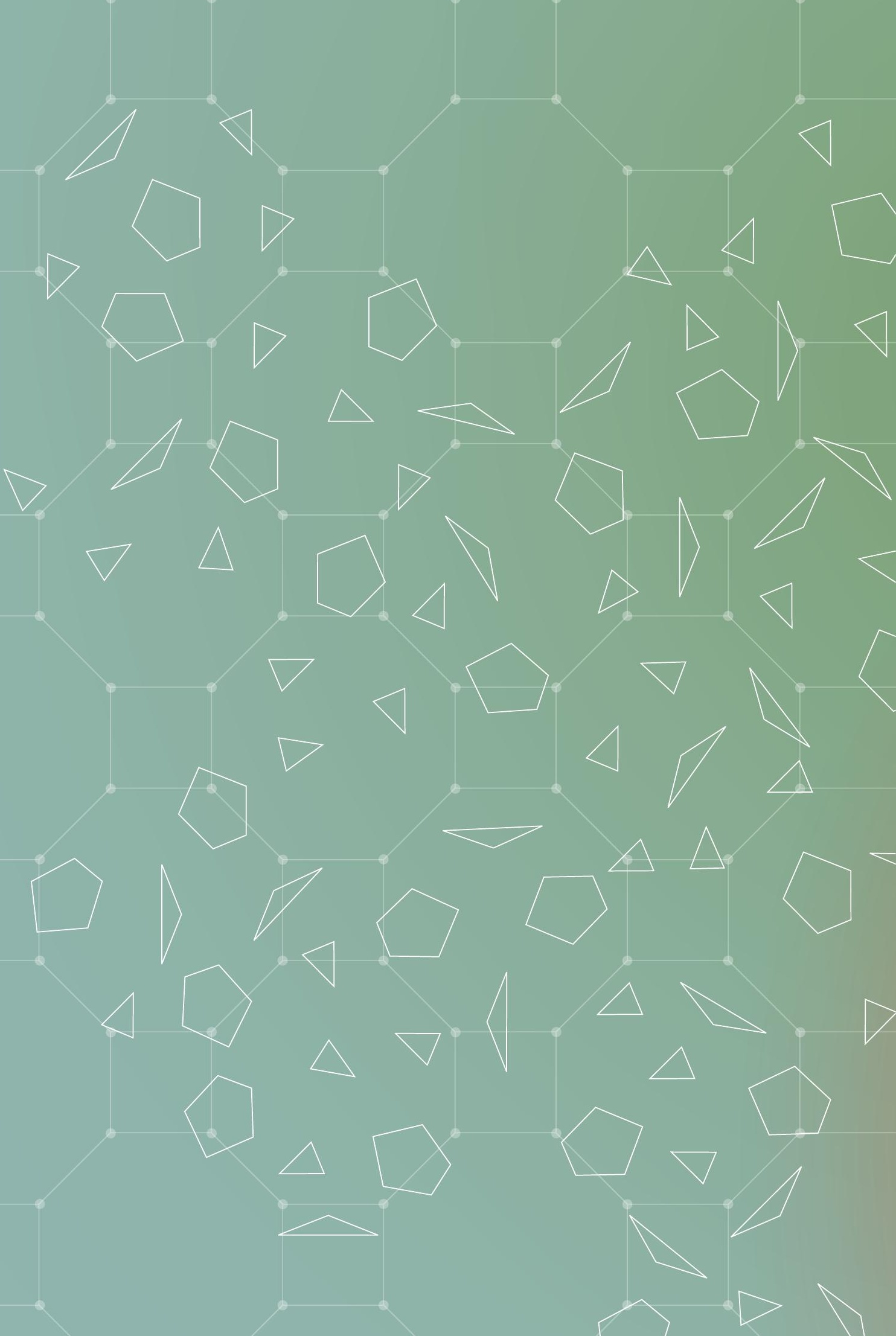




\section{INLEIDING}

\subsection{DE BLINDE VLEK IN DE TECHNOLOGISCHE CULTUUR: RELIGIE}

Technologie en religie zijn belangrijke factoren in de wereld, de samenleving en het leven van mensen. Globalisering en internationale mobiliteit, ondersteund door het wereldwijde web en andere informatieen communicatietechnologieën, maken het mogelijk dat we eenvoudiger dan ooit in contact komen met verschillende religieuze tradities en overtuigingen. Religie geeft structuur en inspireert mensen. Wat betekent dat voor onze inspiratie voor innovatie? Wat is de wisselwerking tussen technologie en religie bij de vormgeving van de samenleving? Hoe geven onze overtuigingen en idealen vorm aan technologie en hoe vormt technologie op haar beurt onze idealen en praktijken voor het goede leven?

In westerse samenlevingen wordt uitvoerig geschreven en gedebatteerd over de verhouding tussen wetenschap en geloof, maar er is vrijwel geen aandacht voor de relatie tussen technologie en religie.

De rol van religie is een blinde vlek in het denken over en onderzoeken van technologische ontwikkeling. Deze studie werpt licht op die blinde vlek en geeft inzicht in de rol van religie in de hedendaagse technologische cultuur. 
De afgelopen decennia zijn vele aspecten van de technologische cultuur onderzocht, zoals het economische ${ }^{1}$, sociaal-culturele ${ }^{2}$, esthetische $^{3}$, juridische ${ }^{4}$, ethische ${ }^{5}$ en politieke ${ }^{6}$. Vreemd genoeg ontbreekt het religieuze aspect vrijwel volledig in het onderzoek naar de technologische cultuur en juist dat aspect is voor vele culturen onderscheidend. Veel bewoners van de technologische cultuur zullen zeggen dat het juist karakteristiek voor een technologische cultuur is dat ze op hun gezond verstand vertrouwen en op technisch-wetenschappelijke kennis van de wereld. Religie wordt dan in een technologische cultuur niet van belang geacht. De gedachte is dat het onderscheidend is voor een technologische cultuur dat ze bouwt en vertrouwt op technologie en het eigen kunnen van de mens. Daar lijken we een kern van de technologische cultuur te raken. In zo'n cultuur is het een breed gedeelde overtuiging dat we kunnen, moeten en mogen vertrouwen op het eigen kunnen van de mens en de technische mogelijkheden. Die basale houding wil ik in dit proefschrift verder onderzoeken.

In dit hoofdstuk leid ik de herkomst van het vraagstuk rond de verwevenheid van technologie en religie in aan de hand van de secularisatietheorie en het alternatief daarvoor: het denken over religie in termen van transformatie. Met behulp van het concept technologische cultuur introduceer ik een nieuwe perspectief op de verwevenheid van technologie en religie. Vervolgens presenteer ik de casus PAZIO die in deze studie geanalyseerd wordt om zicht te krijgen op de rol van religie in de technologische cultuur. Daarna wordt de gebruikte onderzoeksmethodiek beschreven. Het hoofdstuk wordt afgesloten met een leeswijzer voor het verdere boek.

\footnotetext{
1 Dosi, Freeman, en Nelson, Technical change and economic theory.

2 Smits, 'Monsterbezwering'.

3 Kockelkoren, Techniek: kunst, kermis en theater.

4 Jasanoff, Science at the bar: law, science, and technology in America.

5 Swierstra, Heracliteïsche ethiek: omgaan met de soft impacts van technologie. 
De begrippen technologie en religie roepen ieder hun eigen beelden en associaties op die niet vanzelfsprekend op een verwevenheid duiden. Bij technologie gaat het om de dingen die we maken, veelal harde materiele objecten die door logisch denken ontwikkeld zijn. Het zijn producten van de menselijke rationaliteit. Die producten werken overal en maken geen onderscheid in gebruikers; het zijn objectieve, neutrale en universeel werkende dingen. Technologie staat voor vooruitgang en innovatie: zoals Philips, Nederlands technologische trots, het jarenlang uitdrukte 'let's make things better'?

Religie roept vrijwel de tegenovergestelde associaties en beelden op. Religie zou gaan om verhalen en dogma's, de dingen doen er veel minder toe. Veel meer dan rationeel, zou religie spiritueel zijn en niet innovatief maar conservatief of in ieder geval traditioneel. Religie is een relict van vroeger, gericht op stabiliteit in plaats van ontwikkeling en innovatie. Religie is persoonlijk, normatief en aan plaats, tijd en in ieder geval cultuur gebonden.

Dergelijke beelden van technologie en religie kunnen eenvoudig verleiden tot de conclusie dat technologie en religie tegenovergestelden van elkaar zijn en verder geen relatie of verwevenheid kennen. Ze botsen met elkaar of komen uit verschillende plaatsen of tijden. De gedachte dat technologie en religie met elkaar samenhangen, gaat tegen de intuïties van de Westerse Europese culturen in. Die intuïtie wordt in belangrijke mate gevoed door de seculariseringsthese die de socioloog Max Weber aan het begin van de twintigste eeuw introduceerde. ${ }^{8}$

Weber stelt dat met de opkomst van moderne wetenschap en technologie, religie zal verdwijnen. Religie verdwijnt volgens hem uit het publieke domein en verdwijnt achter de voordeur of verdwijnt helemaal. De rationalisering die met de Verlichting is in gezet, leidt volgens Weber tot een onttovering van de wereld. Deze seculariseringsthese leidt tot debatten waarin wetenschap en technologie tegenover religie komen te staan en een beeld waarin wetenschap en technologie religie vervangen. Wetenschappelijke antwoorden over het ontstaan van het heelal en het leven maken religieuze scheppingsverhalen overbodig. Het beeld van religie dat in de seculariseringsthese door Weber wordt gebruikt is functioneel, waarbij de functie van religie bestaat uit het geven van verklaringen 
over de wereld en het leven. Als wetenschap betere verklaringen geeft dan religie, maakt ze religie achterhaald en stoot haar van de troon. Het geloof in wetenschap en technologie kan vanuit die redenatie worden gezien als een nieuwe, verbeterde religie. Die conclusie trekken Weber en de volgers van zijn seculariseringsthese echter niet. Wetenschap en technologie zijn volgens Weber en consorten immers rationeel en onderscheiden zich daarmee van religie.

De seculariseringsthese kent sterke aanhangers en lijkt soms eerder op een politiek programma dan op een wetenschappelijke theorie. ${ }^{9}$ Secularisering is daarin geen gevolg meer van modernisering, maar een voorwaarde voor modernisering en zou volgens haar aanhangers onderdeel van beleid moeten worden. ${ }^{10}$

Vanuit verschillende disciplines is er nuancering en kritiek op de seculariseringsthese. Volgens de socioloog Hans Joas lijdt de secularisatietheorie aan een teleologische vooringenomenheid. Ze gaat uit van een lineaire ontwikkeling waarvan het eindpunt al vast staat: een samenleving zonder religie. ${ }^{11}$ De antropoloog Talal Asad laat zien dat in het Europese seculariseringsproces het seculiere niet zozeer een opvolger is van religie maar dat ze elkaar steeds opnieuw vormgeven en met elkaar verbonden zijn. Er heeft in de loop der tijd een ideologische omkering plaatsgevonden, die Asad als volgt beschrijft:

'For at one time "the secular" was a part of a theological discours (saeculum), while later "the religious" is constituted by secular political and scientific discourses, so that "religion" itself as a historical category and as a universal globalized concept emerges as a construction of Western secular modernity. ${ }^{, 12}$

Jose Casanova wijst erop dat het secularisatieproces onlosmakelijk verbonden is met transformaties van het Europese Christendom en vraagt zich af:

\footnotetext{
9 Illustratief zijn de 'Nieuwe atheïsten' met als frontmannen Richard Dawkins (Dawkins, The God delusion., Daniel Denett (Dennett, Darwin's dangerous idea: evolution and the meanings of life.), Sam Harris (Harris, 'The case against faith.' en Christopher Hitchens (Hitchens, 'Please, let's not do God.'). Zij vinden dat religie niet alleen onwaar is, maar ook slecht is en niet zomaar getolereerd mag worden. Religie moet volgens hen zo veel mogelijk tegengewerkt en bekritiseerd worden.
}

10 Well, 'Another inconvenient truth, interview met Wim van der Donk'. 
'should one define these transformations as a process of internal secularization of Western Christianity, or as the cunning of secular reason, or both?' ${ }^{13}$

Casanova toont verder aan dat religie in de moderne samenleving nog steeds een actieve rol speelt, niet alleen in de private ruimte maar ook in het publiek domein. ${ }^{14}$ De Wetenschappelijke Raad voor het Regeringsbeleid heeft in 2006 uitgebreid onderzoek gedaan naar de rol van religie in het publiek domein en concludeert dat Nederland weliswaar ontkerkelijkt, maar tegelijkertijd dat religie allerminst uit het publiek domein verdwijnt. Er is geen sprake van secularisatie, maar veel meer van een transformatie van religie: religie verdwijnt niet met modernisering, maar verandert mee met maatschappelijke ontwikkelingen. ${ }^{15}$ De secularisatietheorie wordt echter vaak als vanzelfsprekend beschouwd en niet verder bevraagd of genuanceerd. Dat is een gemiste kans voor het begrip van de ontwikkelingen rond religie, samenleving en, zoals hier onderzocht wordt, technologie.

Technologie en religie mogen op het eerste gezicht een vreemde combinatie vormen, als we echter de blik verbreden en naar andere tijden en culturen kijken, lijken ze elkaar in ieder geval niet zonder meer uit te sluiten. Robert K. Merton liet in zijn boek Science, technology and society in seventeenth century England liet zien dat het protestantse piëtisme een belangrijke rol speelde in de ontwikkeling van wetenschap en technologie tijdens de wetenschappelijke revolutie in Engeland..$^{16}$ Ook vandaag de dag zijn technologie en religie onlosmakelijk verbonden. Zo is bijvoorbeeld de Japanse cultuur tegelijkertijd zowel hoogtechnologisch als diepreligieus. ${ }^{17}$ Op een eigen manier is de Amerikaanse droom een droom waarin technologische vooruitgang en religieuze gedragenheid elkaar voortstuwen, ook in Silicon Valley, het hightech centrum van de wereld van vandaag. ${ }^{18}$

Om grip op die verwevenheden te krijgen voldoen standaardbeelden en vooronderstellingen van technologie en religie niet. We moeten verder kijken, minder vooronderstellen en meer onderzoeken. Als we oog willen krijgen voor de relaties en wisselwerkingen tussen technologie en religie, moeten we voorkomen dat we meegaan in de lijn van de seculariseringsthese dat technologie en religie elkaars concurrenten zijn en elkaar uitsluiten. Noch moeten we technologie en religie bij voorbaat zien als

13 Casanova, 'Rethinking secularization', 10.

14 Casanova, Public religions in the modern world.

15 Donk, Geloven in het publieke domein.

16 Merton, Science, technology \& society in seventeenth century England.

17 Nelson, Experimental Buddhism: innovation and activism in contemporary Japan.

18 Zandbergen, 'New edge: technology and spirituality in the San Francisco bay area'. 
twee totaal verschillende orthogonale categorieën die niets met elkaar te maken hebben. De uitdaging is om niet a priori in een tegenstelling te vervallen, waarbij we technologie als rationeel, materieel en innovatief beschouwen en religie zien als spiritueel, metafysisch en conservatief. Het is nodig een frisse, evenwichtige blik te ontwikkelen op technologie en religie, die recht doet aan de prominente rol van technologie en oog heeft voor het belang van religie. Het begrip technologische cultuur biedt zo'n nieuwe blik.

\subsection{TECHNOLOGISCHE CULTUUR}

'Wij leven en denken technologie - in ons werk, in onze communicatie, in ons eten, in de gezondheidszorg, in het onderwijs, in de manier waarop we de wereld vormgeven. Cultuur en technologie zijn niet meer te scheiden. Dat is de realiteit van 'de technologische cultuur'.19

Met deze zin openden Schwartz en Jansma hun boek De technologische cultuur. ${ }^{20}$ Drie decennia later heeft deze karakterisering alleen maar aan kracht gewonnen. Meer dan ooit wordt onze cultuur door technologie bepaald. Het alomvattend net van technologische producten is met de opkomst van digitale technologieën en netwerken alomtegenwoordig, fijnmaziger en persoonlijker geworden. We leven in een technologisch ecosysteem. Technologie is daarin niet alleen een instrument dat aan en uit kan worden gezet, maar kleurt heel ons denken en doen. Technologie geeft vorm aan ons leven en is daarmee moeilijk te onderscheiden van sociale, politieke en religieuze ontwikkelingen. Technologie en religie zijn moeilijk van elkaar te onderscheiden en trekken samen op, zo is de hypothese van dit onderzoek. Door technologische cultuur als eenheid van analyse te gebruiken, ontstaat ruimte om de verwevenheden tussen technologie en religie te onderzoeken.

Technologie heeft de wereld en de samenleving onmiskenbaar veranderd. Moderne informatie en communicatietechnologieën maken kennis meer toegankelijk dan ooit, maar leiden ook tot fenomenen als filter bubbles en fake news. We kunnen eenvoudig contact leggen en houden met mensen over de hele wereld en het is mogelijk om relaties op nieuwe wijze te onderhouden, maar is er ook sprake van nieuwe manieren van pesten, manipuleren en oplichting. Agrotechnologie zorgt dat de opbrengst per hectare landbouwgrond is verveelvoudigd, maar leidt 
tegelijkertijd tot ontbossing, overbevissing en $\mathrm{CO}_{2}$-stijging en zo tot ecologische rampen die volken, mensen en dieren bedreigen. Vele andere besmettelijke ziekten zijn dankzij vaccinatieprogramma's onder controle. ${ }^{21}$ Tegelijkertijd is er de opkomst van andere ziekten, zoals obesitas, hart- en vaatzieken en diabetes die onlosmakelijke verbonden met onze technologische leefstijl en cultuur. In de technologische cultuur is technologie niet noodzakelijk de oplossing voor de problemen maar wel het middel en de manier waarop we problemen proberen op te lossen. In een dergelijke cultuur hebben mensen hoge verwachtingen van technologie. Zo wordt al decennialang beloofd dat ernstige ziekten als kanker en dementie overwonnen zullen worden door wetenschappelijk onderzoek en daaruit voortvloeiende technologische oplossingen. De ernst van de problemen en het perspectief van oplossingen motiveert mensen om geld te doneren aan dergelijke goede doelen. Vanuit de overtuiging dat met giften en sponsorgeld onderzoek gedaan en technologie ontwikkeld kan worden die genezing mogelijk maken, worden omvangrijke organisaties en rituelen opgezet. Een voorbeeld daarvan is Alpe d'HuZes. Deze instelling organiseert jaarlijks een actie waarbij deelnemers 'onder het motto "opgeven is geen optie" op een dag tot maximaal zes keer de legendarische Alpe d'Huez beklimmen om zo veel mogelijk geld in te zamelen in de strijd tegen kanker. Met de opbrengsten wordt wetenschappelijk onderzoek naar kanker ondersteund, met als doel de ziekte onder controle te krijgen, zodat er in de toekomst niemand meer doodgaat aan kanker.'22 In een technologische cultuur hopen we op en werken we aan technologie als het gaat zaken rond leven en dood.

In vrijwel alle culturen wordt de omgang met de grote vragen van het leven en samenleven bepaald door de religieuze achtergrond van de betreffende cultuur. De filosoof en theoloog Paul Tillich beargumenteerde dat "culture is the form of religion and religion is the substance of culture"23 De technologische cultuur lijkt daarop een uitzondering. Dat roept de vraag op of er ook een rol voor religie is in een technologische cultuur en wat die rol dan inhoudt.

De technologische cultuur kent haar varianten. Te denken valt aan de Japanse, Noord-Amerikaanse en West-Europese cultuur. In al deze culturen is technologie een essentieel vormend onderdeel, maar ze

21 De COVID-19-crisis laat zien dat infectieziekten allerminst de wereld uit zijn. De pogingen om het virus te bestrijden met vaccins en apps illustreert de technologische manier van denken en doen. Het toont ook de socio-technische verwevenheid en de grenzen van maakbaarheid en technologische beheersing. 
kennen daarnaast onderling aanzienlijke verschillen. Zo zijn de Japanse en Amerikaanse cultuur, ${ }^{24}$ anders dan de West-Europese cultuur, expliciet religieus van aard. De West-Europese en zeker ook de Nederlandse cultuur worden als sterk seculier beschouwd. Zo is er in juridische zin sprake van een scherpe scheiding van kerk en staat, en zijn ook het domein van wetenschap en economie seculier van aard. Sociaal gezien vindt er een grote kerkverlating plaats en heeft het er alle schijn van dat deze doorzet. Daarbij vindt er een culturele ontwikkeling plaats waarin geloof als een privézaak wordt beschouwd en steeds minder vanzelfsprekend een rol mag spelen in het publiek domein. ${ }^{25}$ De vooronderstelling daarbij is dat religie verdwijnt en dat dat een onvermijdelijk effect van de vooruitgang is. ${ }^{26}$ Die veronderstelling leidt ertoe dat religie een blinde vlek is in de technologische cultuur, ze wordt als irrelevant en een afstervend fenomeen uit het verleden beschouwd. Deze studie wil licht werpen op die blinde vlek en onderzoekt de verwevenheden tussen technologie en religie in de hedendaagse samenleving. In dit onderzoek ligt de focus op de Nederlandse (desgewenst als representant van de West-Europese), en dus seculiere variant van de technologische cultuur. Als in dit proefschrift gesproken wordt over de technologische cultuur wordt daarmee de Nederlandse technologische cultuur bedoeld.

Die technologische cultuur zouden we inhoudelijk kunnen karakteriseren. Dan zouden bijvoorbeeld na de nomaden die over de aarde zwierven en na de boeren die de aarde bewerkten, het nu de techneuten zijn die de aarde met technologie herinrichten. ${ }^{27}$ De filosoof Schuurman kenmerkt de westerse technologische cultuur op meer filosofische wijze als antropocentrisch en technicistisch. In de technologische cultuur staat de mens centraal, is de natuur geïnstrumentaliseerd en God vergeten. Voor de technologieonderzoeker Bijker is de constatering dat we leven in een technologische cultuur allereerst een methodologische positionering, die ons helpt om de hedendaagse complexe, hoogtechnologische samenlevingen te beschrijven en begrijpen. ${ }^{28}$ Cultuur is de omgeving waarin we leven, het vocabulaire dat we spreken, de normen en waarden op basis waarvan we besluiten en de manier waarop we de dingen doen. ${ }^{29}$ Hoe kunnen we vanuit deze methodologische positionering onderzoek doen naar de rol van religie in de technologische cultuur?

24 Wolfe, 'An introduction to American religious practice'.

25 Donk, Geloven in het publieke domein; Casanova, 'Rethinking secularization'.

26 Boutellier, Het seculiere experiment; Taylor, A secular age.

27 Bijker, Democratisering van de technologische cultuur.

28 Bijker, 4.

29 Bijker, 7. 
In dit onderzoek wordt de rol van religie in een technologische cultuur onderzocht door een probe $^{30}$ te nemen van die technologische cultuur. De probe die onderzocht wordt, is de ontwikkeling van PAZIO: een socio-technische ontwikkeling in de gezondheidszorg van de technologische cultuur. Door technologische cultuur als eenheid van analyse te nemen wordt voorkomen dat technologie en religie als onafhankelijke en gescheiden domeinen worden gezien. Dat geeft de ruimte om te onderzoeken hoe technologie en religie verweven zijn in een technologische cultuur.

\section{CASUS PAZIO}

In dit proefschrift onderzoek ik hoe technologie en religie verweven zijn door in detail te kijken naar de ontwikkeling van het gezondheidsportaal PAZIO in de periode 2006 tot en met 2011. Vanaf begin 2010 heb ik als projectmedewerker in het PAZIO-team meegewerkt en kon ik de ontwikkeling van dichtbij volgen. Voordat ik in de volgende hoofdstukken in detail kijk naar deze casus geef ik hieronder eerst een korte beschrijving van de casus op hoofdlijnen.

In de ontwikkeling van PAZIO zijn drie perioden te onderscheiden. De eerste periode draait om de ontwikkeling van het concept PAZIO en de ontwikkeling van een organisatie om PAZIO te realiseren. In de tweede periode wordt een breder netwerk van betrokkenen en sympathisanten ontwikkeld en aan de beeldvorming van PAZIO gewerkt. In de derde periode wordt een pilot opgezet en uitgevoerd in de zorgpraktijk van het Leidsche Rijn Julius Gezondheidscentrum.

\subsubsection{PERIODE 1: ONTWIKKELEN CONCEPT EN ORGANISATIE}

In november 2006 wordt vanuit Mediportaal een notitie over een Patiëntgeoriënteerde Virtuele Zorginfrastructuur (PVZ) geschreven. Mediportaal is een B.V. van het Universitair Medisch Centrum Utrecht (UMCU), gericht op de ontwikkeling van e-health applicaties en digitale gezondheidsportalen. Het PVZ moet het voor patiënten mogelijk maken om betrouwbare informatie over medische kwesties te vinden en om te communiceren met zorgverleners. Daarmee draagt het bij aan het centraal zetten van de patiënt in het zorgproces. Dat betekent dat de patiënt niet langer bij de sites van verschillende zorgverleners inlogt, maar dat de patiënt inlogt op het PVZ en dat de zorgverleners (via hun eigen 
sites) daar hun berichten en data voor de patiënt publiceren. In deze fase denken naast Mediportaal, het UMCU, het eerstelijns onderzoeksinstituut Julius Centrum (van het UMCU) en uitgever Born Stafleu Van Lochem (BSL) mee over het PVZ.

In een volgende versie van de PVZ-notitie wordt PAZIO als werknaam gesuggereerd. PAZIO staat voor: PAtiëntgeoriënteerde ZorgInformatie Omgeving. In oktober 2007 wordt een groep belangstellenden uitgenodigd om mee te denken over de ontwikkeling van PAZIO. Dit leidt tot het schrijven van een overall programmaopzet. Daarin ligt de focus niet zozeer op het product PAZIO maar staat de opzet van het project centraal. De informele bijeenkomst blijkt een voorloper te zijn van wat de stuurgroep voor het project PAZIO wordt. Daarin nemen vertegenwoordigers zitting van UMCU, VitaValley, Vital Health Software, Leidsche Rijn Julius Gezondheidscentra en Imtech. Zij bekrachtigen in februari 2008 hun betrokkenheid bij PAZIO door een convenant te ondertekenen. $\mathrm{Na}$ bespreking van de programmaopzet in de eerste formele bijeenkomst van de stuurgroep wordt een definitiestudie voor PAZIO geschreven. In deze definitiestudie wordt gesteld dat PAZIO het nationale gezondheidsportaal wil worden en dat het primair gericht is op de patiënt.

\subsubsection{PERIODE 2: ONTWIKKELEN VAN NETWERK EN PROFILERING}

Het programmamanagement en de stuurgroep hebben vanaf de start van het project aandacht gehad voor subsidiemogelijkheden voor PAZIO. Parallel aan het conceptplan wordt er al in 2007 gewerkt aan een subsidieaanvraag voor het actieprogramma Maatschappelijke Sectoren \& ICT. In 2008 wordt aan het adviesbureau Deloitte \& Touche een advies gevraagd over de subsidiemogelijkheden voor PAZIO. Op basis daarvan wordt in het najaar van 2008 gestart met het meer systematisch werken aan subsidieaanvragen. Een belangrijk onderdeel van dat werk is het ontwikkelen van draagvlak voor het PAZIO-project door te netwerken en zo steunbetuigingen te krijgen van binnen en buiten de zorg. De steunbetuigingen zijn voorwaardelijk voor een subsidieaanvraag voor Pieken in de Delta (PinDa). Het primaire doel van deze subsidie is economische stimulering van de regio. Het PAZIO-team steekt veel tijd in deze subsidieaanvraag. De PinDa-subsidieaanvraag heeft invloed op de inhoudelijke ambities en positionering van PAZIO. PAZIO moet zichzelf in financiële en inhoudelijke zin 'kantelen om de EZ-subsidie te verkrijgen'. ${ }^{31}$ In de PinDa-subsidieaanvraag wordt PAZIO nu vooral een 'ontsluiting van de 
zorg voor ICT-bedrijven' en creëert ze 'nieuwe bedrijvigheid, werkgelegenheid en opleidingsmogelijkheden in de ICT-sector door het opzetten en exploiteren van een Centre-of-Excellence op het gebied van eHealth'. ${ }^{2}$ Als er uiteindelijk in oktober 2009 twee miljoen wordt aangevraagd en toegezegd, is dat het startschot om echt met het project PAZIO aan de gang te gaan.

VitaValley, een zorginnovatienetwerk en partner in het PAZIO-project, heeft veel van het lobbywerk voor de PinDa-subsidie verricht. VitaValley wil concurrentie tussen portaalinitiatieven voorkomen en zet daarom in op samenwerking. In november 2009 organiseert ze samen met de $\mathrm{NPCF}^{33}$ een bijeenkomst met vertegenwoordigers van andere portaalinitiatieven: de Portaalring. Het ministerie van VWS geeft aan dat zij alleen wil overwegen om portaalontwikkeling te ondersteunen als er enerzijds steun van de NPCF voor het initiatief is en anderzijds sprake is van een enige organisatie van het veld en het toegroeien naar een standaard vanuit het veld. Voor VitaValley is dit één van de motieven en argumenten om de Portaalring samen met de NPCF te organiseren. De vertegenwoordigers van de portaalinitiatieven komen echter niet tot een gemeenschappelijke visie en samenwerking. De Portaalring sterft een stille dood.

Op 11 februari 2010 vindt de officiële kick-off van het PAZIO-project plaats in het UMCU. PAZIO wordt daar groots gepresenteerd als een economische motor voor de regio. Er wordt een film vertoond waarin huisartsen, verzekeraars, patiënten, cliëntenbelang, hoogleraren en directeuren PAZIO aanprijzen als integrator van zorg voor de patiënt. In de film wordt gespeeld met de gedachte dat PAZIO er al zou zijn, maar niets is minder waar. Mw. De Wolf, patiënt bij het LRJG, mag op de knop van het confettikanon drukken en zo het startschot geven voor de ontwikkeling van PAZIO.

\subsubsection{PERIODE 3: PILOT PAZIO@LRJG}

Ondertussen kent de PAZIO-partner Leidsche Rijn Julius Gezondheidscentra (LRJG) onrustige tijden. In 2008 wordt het management ontslagen, een interim bestuurder ingezet om financieel orde op zaken te stellen en worden er een nieuwe algemeen directeur en medisch directeur aangesteld. Dat heeft gevolgen voor de pilot met PAZIO die bij LRJG moet plaatsvinden. Deze loopt vertraging op en als eind 2009 
begonnen wordt met de voorbereidingen, is de motivatie voor nieuwe werkzaamheden en projecten bij het personeel minimaal. Het streven was oorspronkelijk om in drie maanden vijfhonderd patiënten aangemeld te hebben op PAZIO. In april 2010 zijn er echter maar vijftien patiënten aangemeld en wordt PAZIO nauwelijks gebruikt. Huisartsen klagen dat PAZIO niet integreert met hun Huisarts Informatie Systeem (HIS). Zorgverleners leunen in de praktijk volledig op hun HIS en alles wat niet met het HIS samenwerkt vraagt extra tijd en levert extra werk op. De pilot mislukt en de projectleiding van PAZIO verwijt het LRJG dat ze hun belofte om vijfhonderd patiënten aan te melden op PAZIO niet nakomen. De LRJG-directie klaagt op haar beurt dat PAZIO een wankel portaal is omdat het niet integreert met het HIS. Op verzoek van de betrokkenen wordt een evaluatie van de pilot gemaakt en is de conclusie dat PAZIO in zijn huidige vorm nog te weinig meerwaarde voor patiënt en zorgverlener biedt.

Er wordt een revitaliseringsplan voor de pilot bij LRJG opgesteld. Parallel daaraan begint een werkgroep op de LRJG-locatie Vleuterweide een nieuwe pilot voor te bereiden. De werkgroep en LRJG-directie raken ervan overtuigd om voorlopig met PAZIO zonder HIS-integratie te werken en volop in te zetten op portaalintegratie voor de patiënt. Dat betekent dat ze het portaal optimaal inrichten voor de patiënt en dat de zorgverleners accepteren dat het systeem voor hen vooralsnog niet optimaal werkt.

Op 27 mei 2011 komen de betrokkenen bij de PAZIO@LRJG-pilot bij elkaar. De werkgroep laat zien dat en hoe PAZIO werkt voor de LRJGpraktijk in Vleuterweide. Uiteraard zijn er vragen en opmerkingen, maar belangrijker is dat PAZIO@LRJG door de bestuurders van LRJG en PAZIO niet alleen theoretisch, maar ook praktisch goed bevonden wordt en aangeboden gaat worden aan de patiëntenpopulatie van LRJG.

\subsection{METHODE}

\subsubsection{PROBE}

Het doel van deze studie is om antwoord te vinden op de vraag hoe religie een rol speelt in technologieontwikkeling in een technologische cultuur. Om antwoord te kunnen geven op deze vraag is inzicht nodig in de praktijk van technologieontwikkeling met daarbij specifieke aandacht voor de techno-religieuze dynamiek in die praktijk. Om dat inzicht te verkrijgen heb ik een kwalitatief onderzoek opgezet. Gebruik makend van antropologische methoden heb ik de ontwikkeling van het gezondheidsportaal PAZIO als probe genomen in mijn onderzoek. 
Collins en Evans ${ }^{34}$ pleiten ervoor om bij onderzoek naar culturen een probe, een monster te nemen van die cultuur en die kwalitatief te onderzoeken. Ze betogen dat de uniformiteit van een cultuur bepalend is voor de keuze van een geschikte onderzoeksmethode. Een monster, sample of zoals Collins en Evans het noemen een probe zijn bij een uniforme groep net zo representatief als een kwantitatief survey. Ze maken een vergelijking met het nemen van een monster in de natuurwetenschappen. Uniformiteit wordt in de natuurwetenschappen vaak verondersteld. Natuurwetenschappers maken zich geen zorgen over de eigenschappen van natriumatomen buiten de reageerbuis of de bijen in de korf om de hoek, die zijn niet anders dan de atomen en bijen die ze onderzoeken. Het zijn ontologisch uniforme populaties. Een dergelijke uniformiteit is in de sociale wetenschappen minder vanzelfsprekend. Afhankelijk van de onderzoeksvraag kan toch ook hier een probe zeer geschikt zijn. Zo is er om taalkundig te onderzoeken waar in het Engels het werkwoord in de zin wordt geplaatst is er in principe maar één Engelssprekende persoon nodig. Ondanks dat er verschillende Engelse dialecten en jargons zijn te vinden bij Engelssprekende cricketspelers, christenen en Cantabrigians. ${ }^{35}$ In dit onderzoek is de PAZIO-casus een probe om de te onderzoeken of en hoe religie een rol speelt in technologieontwikkeling in een technologische cultuur. Er zijn uiteraard vele andere probes dan de PAZIO-casus mogelijk, in andere velden, rond andere technologische ontwikkelingen en met andere groepen mensen. Er zijn vele verschillende praktijken bruikbaar als probe, maar niet alle probes hoeven onderzocht te worden om tot relevante beantwoording van de onderzoeksvraag te komen. Zoals we de temperatuur van een vloeistof niet op verschillende plekken en met verschillende thermometers hoeven te meten, is het ook niet nodig om meerdere probes uit de technologische cultuur te nemen om inzicht te krijgen in de rol van religie in technologieontwikkeling in die cultuur. Ze kunnen bij andere onderzoeksvragen interessante en relevante inzichten opleveren, maar in dit stadium zijn ze niet van belang. De technologische cultuur is voldoende homogeen met haar focus op innovatie, haar wetenschappelijke grondhouding en zoeken naar technologische oplossingen. De PAZIO-casus biedt een geschikte probe om te onderzoeken of en hoe religie een rol speelt in technologieontwikkeling in een technologische cultuur. De PAZIO-casus speelt zich af in een duidelijk tijdvak en tussen een beperkt aantal spelers. Ze biedt daarmee een goed afgebakende probe. In PAZIO-casus staat technologieontwikkeling in de waarden geladen 
context van de zorg centraal. Het is daarmee een technologische ontwikkeling in het hart van de cultuur. Zorg is immers onlosmakelijk verbonden met het menselijk bestaan en kent in elke cultuur een eigen uitwerking. Technologische ontwikkeling in de zorg zou daarom een geschikte probe moeten zijn voor onderzoek naar de verwevenheid van technologie en religie in de technologische cultuur. Het onderzoeken van de PAZIOprobe geeft een kwalitatief inzicht in de technologische cultuur. Op basis van dat kwalitatieve inzicht kunnen theoretische generalisaties gedaan worden.

\subsubsection{PARTICIPERENDE OBSERVATIE}

De ontwikkeling van PAZIO wordt als probe genomen om inzicht in de rol van religie in technologieontwikkeling binnen de technologische cultuur te komen. In dit onderzoek is gekozen voor de methode van participerende observatie om data te verzamelen en gevoel voor de cultuur te ontwikkelen. Dat vraagt van de participerende observator het vermogen om balans te vinden tussen empathische betrokkenheid en kritische distantie. De onderzoeker wordt als participerende observator het meetinstrument, dat in de technologische cultuur de techno-religieuze dynamiek bepaalt. De participerende observator betreedt daartoe als etnograaf het veld, ontwikkelt relaties, doet observaties en legt verbanden en komt zo tot zijn meetresultaat. ${ }^{36}$ Kalibratie van het meetinstrument is hierbij essentieel. De onderzoeker participeert in de onderzochte praktijk. En zoals elk meetinstrument beïnvloedt hij door zijn participatie in meer of mindere mate de ontwikkelingen in de probe en wordt hijzelf beïnvloed door zijn meting ofwel opgedane ervaring. Een dergelijke ontwikkeling is onoverkomelijk en bij etnografische onderzoek zelfs wenselijk. De etnografische onderzoeker heeft een lerende rol. Dat maakt het mogelijk de meting steeds verfijnder te maken en fijngevoelig af te stemmen op de ontwikkelingen in de praktijk. Tegelijkertijd zijn er risico's aan verbonden. De onderzoeker kan niet anders dan zichzelf meenemen en daar ligt zowel zijn kracht als zijn kwetsbaarheid. Het vraagt van de onderzoeker een open, scherp observerende en analyserende blik, met daarnaast het reflexief vermogen om eigen idealen en veronderstellingen te onderkennen. 


\subsubsection{PRAKTIJK}

Voor een antropoloog is toegang tot de te bestuderen cultuur en de manier waarop die toegang verkregen wordt van groot belang. Is de onderzoeker gelegitimeerd, geaccepteerd of wordt hij of zij met wantrouwen bekeken? ${ }^{37} \mathrm{Ik}$ kreeg een warme toegang tot PAZIO. Dat kwam doordat ik niet alleen onderzoek deed, maar ook actief meewerkte aan het project. Daarnaast kreeg ik toegang via vertrouwde poortwachters voor het project: de stuurgroep voorzitter Kuilboer; Verkerk, voorzitter van VitaValley, en De Lange, een van de twee projectleiders van PAZIO.

Ik kwam formeel in april 2010 in dienst van VitaValley. Op 11 februari 2010 begon ik echter in praktische zin al aan mijn onderzoek. Ik bezocht de kick-off bijeenkomst van PAZIO. Op dat moment realiseerde ik het me niet zozeer, maar achteraf gezien is dat een cruciaal moment in het onderzoek geworden, zoals in het vervolg zal blijken. Van april 2010 tot en met mei 2011 heb ik vervolgens actief, continu en voltijds meegewerkt aan de ontwikkeling van PAZIO. Ik was lid van het projectteam waarin mijn rol en taken gevarieerd waren. Ik was betrokken bij de wekelijkse projectteam-overleggen en deed het werk dat daarbij hoorde Zo schreef ik een samenwerkingsovereenkomst tussen PharmaPartners en PAZIO, maakte voorstellen voor het Centre of Excellence, en overlegde met betrokken partijen bestaande uit medici, bestuurders, patiënten en ICT-leveranciers als Imtech en Pharmeon. Het belangrijkste en grootste onderdeel van mijn werk was uiteindelijk de begeleiding van de pilot implementatie van PAZIO bij het Leidsche Rijn Julius Gezondheidscentrum. De afronding van die implementatie in mei 2011 was ook de afronding van mijn werkzaamheden voor PAZIO.

Mijn dubbelrol als onderzoeker van en projectmedewerker aan de ontwikkeling van PAZIO maakte het mogelijk om op een vanzelfsprekende wijze zowel te participeren als te observeren. Vanuit mijn medewerkersrol werd ik vanzelfsprekend onderdeel van het project waar ik ook onderzoek naar deed. Ik nam gedurende meer dan een jaar deel aan de projectteamoverleggen en liep rond bij het LRJG terwijl daar de eerste pilot werd opgezet. Zo kwam ik op natuurlijke wijze in contact met bestuurders, medewerkers en andere betrokkenen, had de tijd om een relatie met hen op te bouwen en om informele gesprekken te voeren en naturalistic interviews ${ }^{39}$ af te nemen. Ik kon de ontwikkeling van PAZIO van binnenuit

\footnotetext{
37 Walsh, 231; Verkerk, 'Trust and power on the shop floor', 166-77.

38 Voor de volledigheid: in 2014 schreef ik voor VitaValley en PAZIO een gehonoreerde subsidieaanvraag bij ZonMw voor het programma 'De zorg ontzorgd met ICT'. Het opschalingsproject rond PAZIO dat daaruit voortkwam in 2015-2016 heb ik begeleid. Deze periode en werkzaamheden vallen echter buiten het bestek van deze studie. 39 Walsh, 'Doing ethnography', 233.
} 
meemaken en bestuderen en me onderdompelen in de praktijk van deze zorginnovatie.

Het Universitair Medische Centrum Utrecht en het LRJG zijn beide ingericht en ingesteld op het doen van onderzoek. Het UMCU is een academisch ziekenhuis dat zowel een zorg- als onderzoeksdoelstelling heeft. LRJG is mede opgericht door het UMCU om een onderzoek infrastructuur voor een groots epidemiologisch onderzoek te ontwikkelen, dat in de pas liep met de ontwikkeling van de VINEX-wijk Leidsche Rijn.. ${ }^{40}$ Het LRJG noemt zichzelf in lijn met het academisch ziekenhuis een academische eerstelijns praktijk. ${ }^{41}$ Mijn dubbelrol als medewerker en onderzoeker was in die context geen uitzondering. Ik was voor veel betrokkenen een variant op de co-assistenten en al dan niet promoverende onderzoekers in de zorgpraktijk.

Mijn directe collega's in het PAZIO-team wisten dat ik onderzoek deed naar ons werk en ook de medewerkers van het LRJG waar ik geruime tijd intensief mee samenwerkte vertelde ik bij aanvang over mijn onderzoek. Mijn gesprekspartners namen dat over het algemeen voor kennisgeving aan en desgewenst gaf ik hen verdere toelichting.

Mijn dataverzamelingwerk werd in de praktijk vooral zichtbaar in de hoeveelheid aantekeningen die ik maakte tijdens bijeenkomsten, besprekingen en overleggen. In mijn aantekeningen beschreef ik de dynamiek van besprekingen, schreef citaten op, beschreef de context, de non verbale communicatie, het gebruik van materialen, de manier waarop mensen met elkaar omgingen, de relaties, hoe men elkaar overtuigde of tegen zich in het harnas joeg en het performatieve effect daarvan voor het project. In veertien maanden schreef ik zo in de praktijk negen logboeken van 220 pagina's A5 vol met aantekeningen van observaties. De aantekeningen werkte ik aan het eind van de dag uit in Word documenten. Dat deed ik van begin tot eind op chronologische volgorde en per dag. Iedere maand begon ik een nieuw document. Een gemiddelde maand resulteerde in een digitaal document van zo'n dertig pagina's A4. Af en toe maakte ik een beschouwende of interpretatieve opmerking over het materiaal in mijn uitgewerkte logboek, dat was echter meer uitzondering dan regel.

Als medewerker leerde ik niet alleen de mensen en activiteiten in het PAZIO-project kennen, ook kreeg ik toegang tot alle opgeslagen documentatie. Bij PAZIO werd een digitale projectstructuur gebruikt met de 
naam PPOD. PPOD stond voor Project Place On Demand, het was een op Microsoft SharePoint gebaseerde tool voor het delen en bewaren van data. De documenten in PPOD dateren van 2008 tot 2012 en omvatten de belangrijkste periode van dit onderzoek. Stuurgroepverslagen, projectplannen, subsidieaanvragen, promotiematerialen, filmscripts en films zijn alle terug te vinden op PPOD.

Naast PPOD kreeg ik de beschikking over de e-mailberichten die de directbetrokkenen Verkerk en De Lange van 2007 t/m 2012 in het kader van PAZIO verstuurden en ontvingen. Zo kreeg ik ook toegang tot een bron van meer informele communicatie binnen het project.

Hoewel ik geen hoofdrolspeler in de ontwikkeling van PAZIO was, heb ik op enkele momenten wel relevante interventies gedaan. De meeste impact heb ik gehad rond de implementatie pilot bij LRJG in Vleuterweide. Nadat de eerste pilot bij LRJG was vastgelopen, schreef ik een evaluatie waarin ik liet zien dat PAZIO veel te weinig meerwaarde toonde voor haar eindgebruikers, namelijk patiënten en zorgverleners. Daarmee verlegde ik de focus van de technische-operationele werking van het product naar de meerwaarde van dat product voor de gebruikers. De technische blik werd vervangen door een perspectief op de meerwaarde in de praktijk.

Een tweede relevante interventie deed ik door in de ontwikkeling de bestuurders en zorgverleners de keuze tussen twee eindgebruikers voor te leggen: zetten we de patiënt of de zorgverlener centraal in de ontwikkeling? Tot die tijd was er vooral gewerkt aan een invulling van PAZIO die paste bij de zorgverleners. Er werd heel veel tijd en geld geïnvesteerd in de koppeling van PAZIO met het huisartsinformatiesysteem (HIS). Dat was heel waardevol voor de zorgverleners, maar irrelevant voor de patiënt. Ik introduceerde de keuze tussen twee ontwikkelopties: leggen we de prioriteit bij 1) HIS-integratie voor de zorgverleners of 2) bij portaalintegratie voor de patiënt. Uiteindelijk is gekozen voor portaalintegratie en daarmee voor service aan de patiënt.

\subsubsection{PERSPECTIEF}

Tijdens de participerende observatie in het PAZIO-project waren veel zaken vanzelfsprekend. Ik kon met mijn profiel vanzelfsprekend opgaan in de praktijk van het project en omgekeerd was die praktijk voor mij ook grotendeels vanzelfsprekend. In mijn eerdere werk had ik al veel ervaring opgedaan met zorg, onderzoek en innovatie. In mijn studietijd en loopbaan heb ik me een constructivistisch perspectief ${ }^{42}$ eigen gemaakt. 
Dat perspectief was behulpzaam bij het stellen van vragen bij en analyseren van de vanzelfsprekendheden in de praktijk. Ik vroeg mezelf steeds af hoe zaken als vanzelfsprekend werden gemaakt, gehouden of beschouwd.

Ik hanteerde een methodologisch relativisme: ik deed vooraf geen aannames deed over wat waar, gewoon of goed was. Ik bracht geen hiërarchie aan in interpretaties of de frames die ik tegen kwam. Het perspectief van de winnaars die bepaalden wat goed of waar was, dan wel correct werkte, nam ik niet voor vanzelfsprekend aan, maar probeerde ik juist te verklaren: hoe komt het dat we dit goed, waar of werkend vinden? Niet de feiten, maar de constructie van de feiten stond centraal.43

\section{LEESWIJZER}

In hoofdstuk 2 beschrijf ik de theorie die het vertrekpunt vormt voor dit onderzoek en introduceer ik drie theoretische perspectieven voor dat onderzoek, namelijk het Triple I model (TIM), de Social Construction of Technology benadering (SCOT) en de theorie over religie zoals ontwikkeld door Durkheim. Het hoofdstuk sluit af met de centrale onderzoeksvraag, die luidt: hoe wordt in een technologische cultuur vormgegeven aan het sacrale?

In de daaropvolgende hoofdstukken geef ik een gedetailleerde beschrijving van de ontwikkeling van PAZIO. Op basis van het etnografisch empirisch materiaal wordt in hoofdstuk 3, 4 en 5 achtereenvolgens aandacht besteed aan de ontwikkeling van: geloof, rituelen, sociale verbanden en dynamiek in de sacrale vorm rond PAZIO.

Ik sluit af met hoofdstuk 6 waarin op basis van het empirisch materiaal conclusies getrokken worden. Geconcludeerd wordt dat religie een onmiskenbaar onderdeel is van de technologische cultuur en dat aandacht voor het sacrale een beter begrip geeft van de aard en richting van socio-technische veranderingen. Op basis van de opgedane inzichten presenteer ik een model om het sacrale in een technologische cultuur te begrijpen en onderzoeken. 



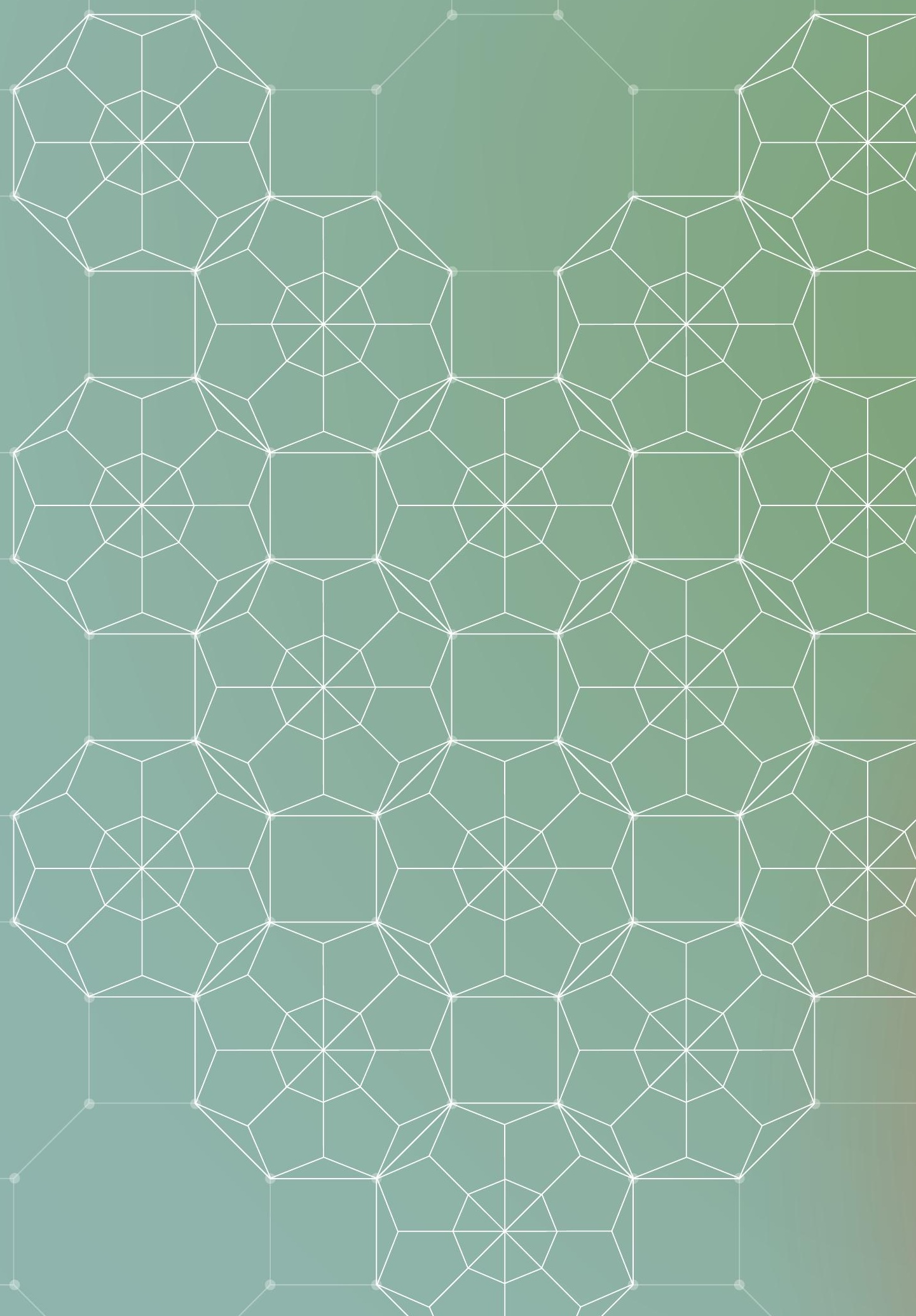



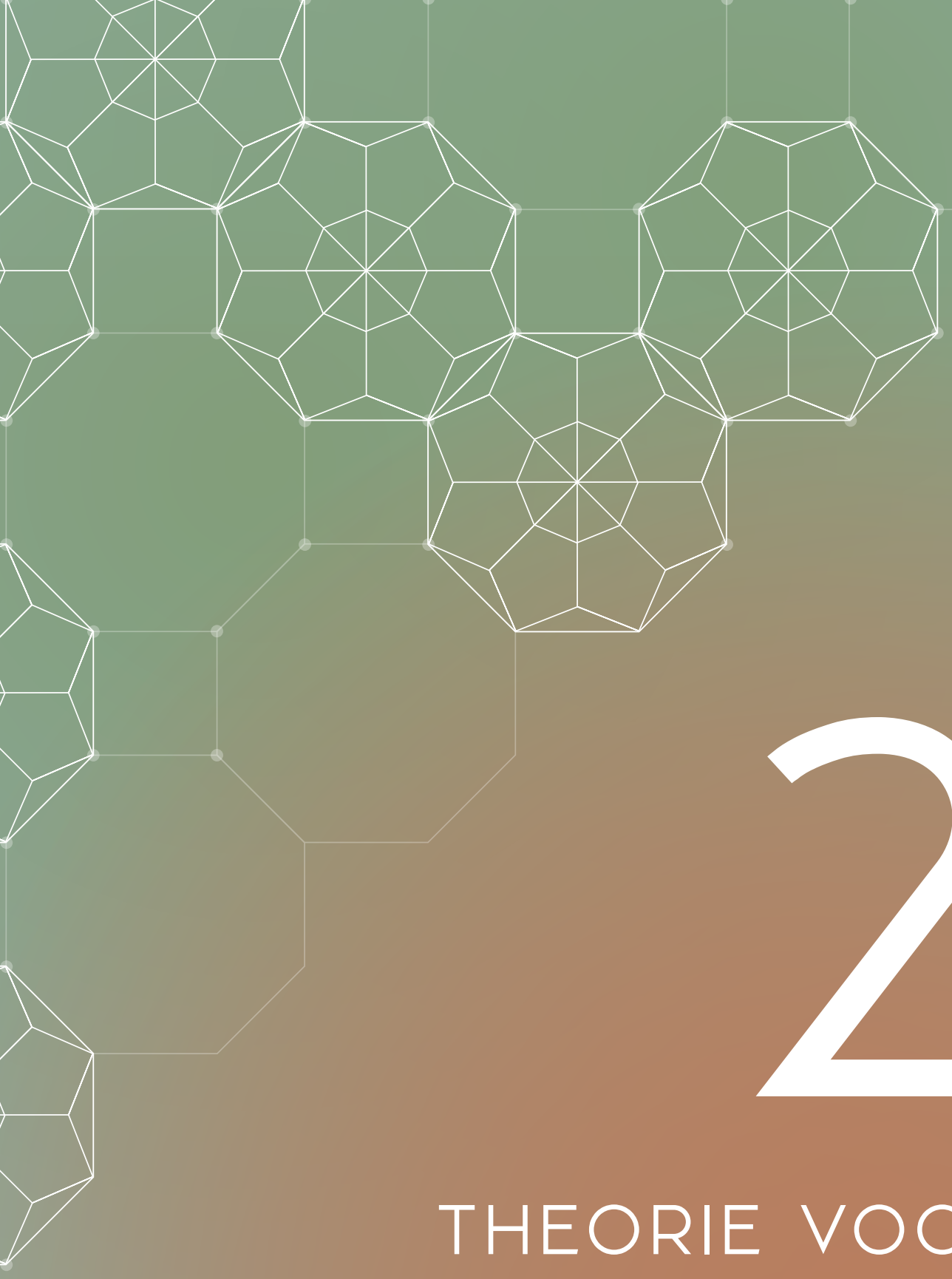

\section{THEORIE VOOR}

HET ONDERZOEKEN VAN RELIGIE EN TECHNOLOGIE 


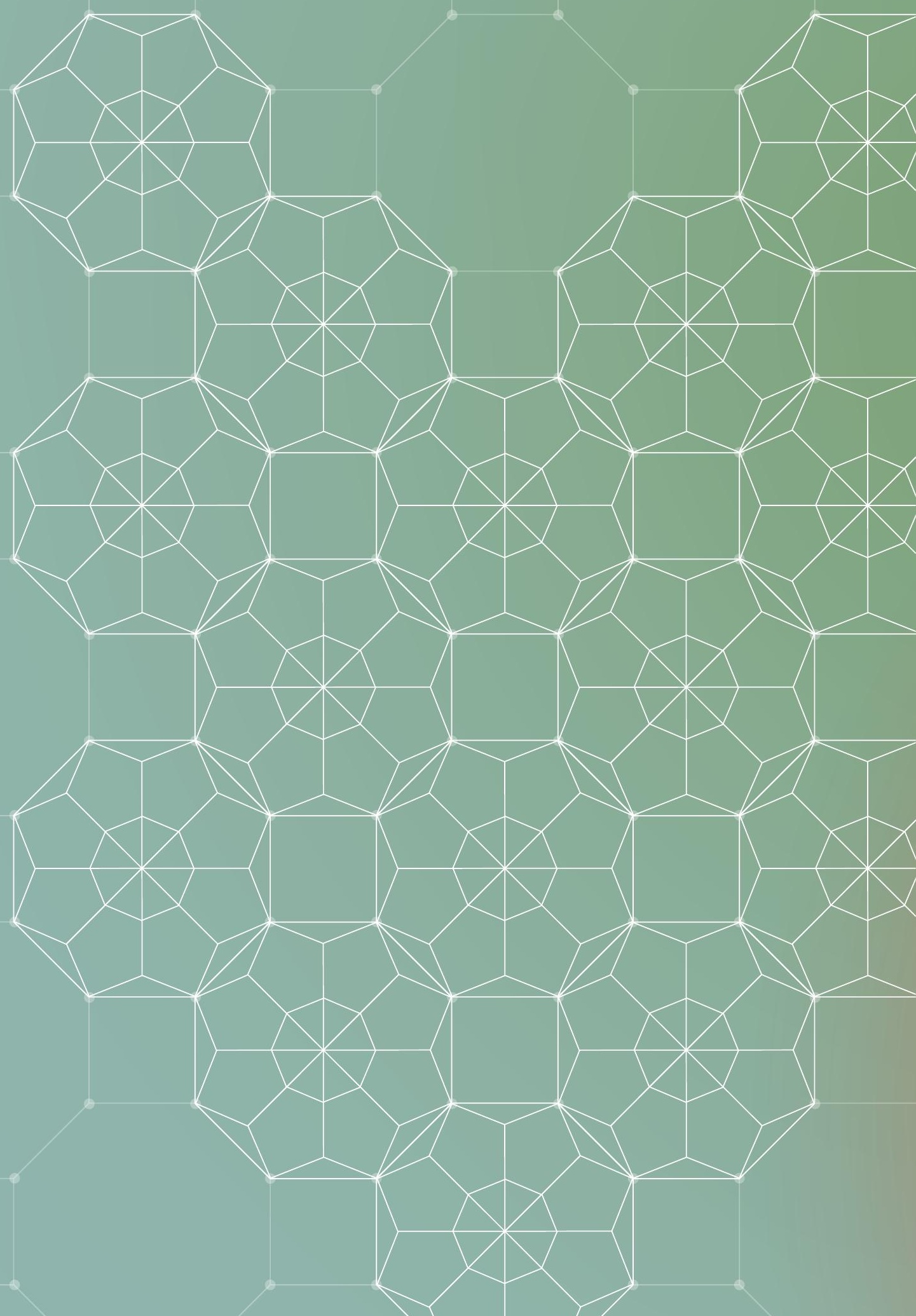




\section{THEORIE VOOR HET ONDERZOEKEN VAN RELIGIE EN TECHNOLOGIE}

\subsection{INLEIDING}

In dit hoofdstuk wordt de huidige technologische cultuur in de context van andere plaatsen en tijden geplaatst. Op basis van het literatuuronderzoek wordt duidelijk dat religie door de eeuwen heen verschillende transformaties heeft doorgemaakt en dat die transformaties steeds hun weerslag hebben gehad op de rol en waardering van technologie. Dat die dynamiek niet iets is van het verleden wordt zichtbaar in de huidige Amerikaanse civil religion, waarin technologie een belangrijke rol speelt. Dat roept de vraag op hoe technologie en religie verweven zijn in de West Europese technologische cultuur.

Om de verwevenheid tussen technologie en religie te onderzoeken in de PAZIO-probe, worden vervolgens drie theoretische perspectieven gepresenteerd: het Triple I model om professionele praktijken te analyseren aan de hand van hun identiteit en waarden, de Social Construction of Technology benadering voor onderzoek naar socio-technische verandering en Durkheims sociale benadering van religie, waarin het sacrale een centraal concept is.

Tot slot wordt op basis van de geïntroduceerde theorie, de centrale onderzoeksvraag met bijbehorende subvragen geformuleerd. 


\subsection{TECHNOLOGIE EN RELIGIE DOOR DE EEUWEN HEEN}

\subsubsection{DE INVLOED VAN TECHNOLOGIE OP RELIGIE}

Door de eeuwen heen is goed zichtbaar dat religie mede vorm krijgt door technologie. Dat wordt in een oogopslag zichtbaar in religieuze bouwwerken als kathedralen, moskeeën en tempels, ${ }^{44}$ maar ook als we nadenken over het belang van het schrift, ${ }^{45}$ boekdrukkunst en de hedendaagse social media voor religieuze praktijken. ${ }^{46}$

In de religieuze praktijk spelen naast geloof en sociale verbanden ook rituelen en artefacten een belangrijke rol. Er heeft zich een aanzienlijk onderzoekstraditie ontwikkeld waarin de materiële kanten van religie en de rol van artefacten en technologie in religieuze praktijken onderzocht worden. ${ }^{47}$ Dat artefacten en technologie belangrijk zijn in religie, zien we in de ontwikkeling van communicatietechnologie en hun rol in de transformaties van religie. ${ }^{48}$ Zo zijn in de christelijke religieuze traditie de Reformatie en de ontwikkeling van de boekdrukkunst in de zestiende eeuw nauw met elkaar verweven. Het moge onzeker zijn dat Luther de 95 stellingen die hij schreef ook daadwerkelijk aan de deuren van de Slotkerk in Wittenburg heeft gespijkerd, zeker is wel dat Luther door de boekdrukkunst zijn stellingen kon publiceren en verspreiden. Daardoor werd het mogelijk om brede groepen te informeren en te betrekken in zijn streven naar reformatie van de kerk. De boekdrukkunst maakte het ook mogelijk dat Luthers vertaling van de Bijbel in het Duits de weg naar de bevolking vond. Door de ruime verspreiding werd het daadwerkelijk mogelijk dat meer mensen zelf en zonder tussenkomst van de RoomsKatholieke geestelijkheid de Bijbel konden lezen.

Van der Stoep beschrijft in de Oecumene van het hart een vergelijkbare ontwikkeling. Sociale media, moderne mobiliteit en de beleving die mogelijk gemaakt wordt door technologie bij grote events als het Flevofestival of de EO-jongerendag, zorgen ervoor dat protestantse en evangelische jongeren hun geloof steeds minder halen uit de Bijbel die ze zelf lezen of horen uitleggen in de kerk in hun dorp of stad. Christelijke

\footnotetext{
44 Bouw, 'Architectuur en dominee, twee handen op een buik'.

45 Munnik, 'Schriftreligies, technologisch gemedieerde religies?'

46 Veer, Peter van der, 'Religie, technologie en communicatie'; Meyer, 'Religious sensations: why media, aesthetics and

power matter in the study of contemporary religion'.

47 Houtman en Meyer, Things: religion and the question of materiality.

48 Vries en Weber, Religion and media.
} 
jongeren ontmoeten elkaar steeds vaker op sociale media en reizen van heinde en verre naar het Gelredome in Arnhem voor de EO jongerendag. Ondersteund met licht, geluid en show gaan ze op in een praise viering. Daarin staat niet de overdenking van de Bijbel centraal maar de collectieve geloofsbeleving. Zo ontsluiten nieuwe media en technologie nieuwe geloofservaringen naast of in plaats van de meer klassieke kerkdienst op de zondagochtend in de eigen kerk. ${ }^{49}$

\subsubsection{NOBLE OVER DE INVLOED VAN RELIGIE OP TECHNOLOGIE}

Over de rol van religie op technologische ontwikkeling is minder gepubliceerd dan over de invloed van technologische ontwikkeling op religie. Dat is begrijpelijk als er geredeneerd wordt vanuit de hiervoor besproken seculariseringsthese van Weber, want daarin is religie een door modernisering verdwijnend fenomeen dat niet langer relevant is voor bijvoorbeeld technologische ontwikkeling.

De historicus David Noble heeft desondanks een toonaangevend boek geschreven over de invloed van religie op technologie: The religion of technology ${ }^{5 \circ}$. Noble ziet secularisering als relevant, maar niet vanzelfsprekend voor een technologische cultuur. Hij weerspreekt in zijn boek de gedachte dat religie geen rol speelt in technologische ontwikkeling en daarbij vanzelfsprekend verdwijnt. Aan de hand van de geschiedenis van technologische ontwikkelingen in Europa van de afgelopen eeuwen laat Noble zien hoe religie mede richting geeft aan technologische ontwikkelingen. Technologieontwikkeling was een door en door religieuze onderneming. Noble stelt in zijn boek religie gelijk aan het Christendom en geeft geen verdere uitleg van wat hij onder religie verstaat. In zijn boek ligt de focus echter op religieuze verhalen en overtuigingen en is er vrijwel geen aandacht voor religieuze praktijken of rituelen.

Noble beschrijft dat volgens de Augustinus de verlossing van de aardse last van de mens alleen mogelijk zou zijn door Gods genade. Technologie zou daarin geen rol spelen. Die relatie tussen technologie en transcendentie begon in de middeleeuwen echter te veranderen. Technologie wordt onderdeel van het idee dat het de bestemming van de mens is om Gods evenbeeld, Imago Dei, te worden en te werken aan de realisatie van zijn Koninkrijk. Technologie wordt daarin een heilig middel voor de mens om de aarde te bewerken en zó aan verlossing te werken. Volgens Noble komt die gedachte door de eeuwen heen in meer 
of mindere mate en verschillende gedaanten steeds terug. Noach bouwde de ark, Salomo de tempel en in die lijn zou de mens door technologie ook de perfectie van Adam in het paradijs weer kunnen herkrijgen en aan het Nieuwe Jeruzalem kunnen bouwen. Technologie maakt de mens gelijk aan, dan wel partner van, een God die blijvend aan zijn schepping werkt. Technologie wordt gezien als gave van God aan de mens om daarmee aan de verlossing van aardse lasten te werken. Met zijn betoog laat Noble zien hoe religie en technologie een gezamenlijke geschiedenis hebben en dat daardoor 'the technological enterprise has been and remains suffused with religious belief. ${ }^{51}$

In de relatie tussen technologie en religie legt Nobel de focus op de invloed van religie op technologische ontwikkeling. Noble duidt die verwevenheid echter allerminst positief. Religie is voor Noble een bron die technologische ontwikkelingen afhoudt van de juiste koers. Met zijn boek hoopt hij te bewerkstelligen:

'that we might learn to disabuse ourselves of the other-worldly dreams that lie at the heart of our technological enterprise, in order to begin to redirect our astonishing capabilities towards more worldly and humane ends.' ${ }^{52}$

Noble gelooft dat een scheiding van technologie en religie wenselijk is. Het is voor hem een belangrijke voorwaarde om te komen tot een goede moderne samenleving. Secularisering is voor hem echter geen vanzelfsprekendheid, maar wel een belangrijk doel en programma. Noble's historische analyse is rijk aan voorbeelden en inzichten in de relatie tussen religie en technologie. Zijn conclusie dat er scheiding moet zijn tussen technologie en religie, staat daar vreemd genoeg haaks op. De verwevenheid tussen technologie en religie die Noble in de geschiedenis bespeurt en verfoeit, maakt zijn werk paradoxaal genoeg tot een mooi vertrek- en afzetpunt voor de voorliggende studie waarin we kijken naar de verwevenheid van technologie en religie.

In Noble's denken over de toekomst van technologie en religie komt technologie weliswaar los te staan van het christelijke geloof, maar tegelijkertijd wordt die religieuze leemte gevuld met de idealen, hoop en de verwachting van de seculiere rationele ongelovige. Het geloof in de christelijke God wordt vervangen door een seculier geloof in de rationele en atheïstische mens. De inhoud van dat geloof mag bestaan uit ongeloof 
en rationaliteit, maar dat maakt het geloof op zich niet meer rationeel noch minder religieus. Noble maakt technologie kortom niet los van religie, maar vervangt de ene religie door de andere. ${ }^{53}$

\subsubsection{DE GRONDMOTIEVEN VAN DOOYEWEERD}

Is een samenleving of gemeenschap zonder religie mogelijk? De filosofen Dooyeweerd en Szerszynski beantwoorden die vraag, ieder op hun eigen wijze, ontkennend. Zij geven niet alleen mooie inzichten in het onvermijdelijk religieuze karakter van mens, cultuur en samenleving, maar hebben daarbij ook specifieke aandacht voor de rol van technologie. Dooyeweerd is één van de grondleggers van de Reformatorische wijsbegeerte. Deze filosofische school heeft de afgelopen decennia uitgebreid nagedacht over de rol van zowel religie als technologie in de samenleving. Szerszynski besteedt in zijn boek Nature, technology and the sacred niet alleen aandacht aan de ontwikkeling van het sacrale, maar legt ook expliciet het verband met technologische ontwikkelingen. Dat maakt het werk van deze filosofen interessant en relevant. Beide filosofen ondernemen een reis op zevenmijlslaarzen door de geschiedenis van de mensheid en onderscheiden daarbij verschillende perioden die gekarakteriseerd worden door verschillende grondmotieven van het bestaan (Dooyeweerd) of door verschillende vormen van het sacrale (Szerszynski).

Herman Dooyeweerd benadrukt in zijn boek Vernieuwing en bezinning dat de ontwikkeling van de westerse cultuur in grote mate gedreven wordt door religieuze grondmotieven. ${ }^{54}$ Daarin is religie een breed begrip: het gaat om de geestelijke drijfkracht of diepste motieven, die dragend zijn voor een cultuur. Die grondmotieven zijn essentieel voor een cultuur of samenleving, wat overigens niet noodzakelijk betekent dat ze expliciet benoemd of gepresenteerd worden. Ze zijn zowel essentieel als vanzelfsprekend voor de mensen die in de betreffende cultuur of samenleving leven. 


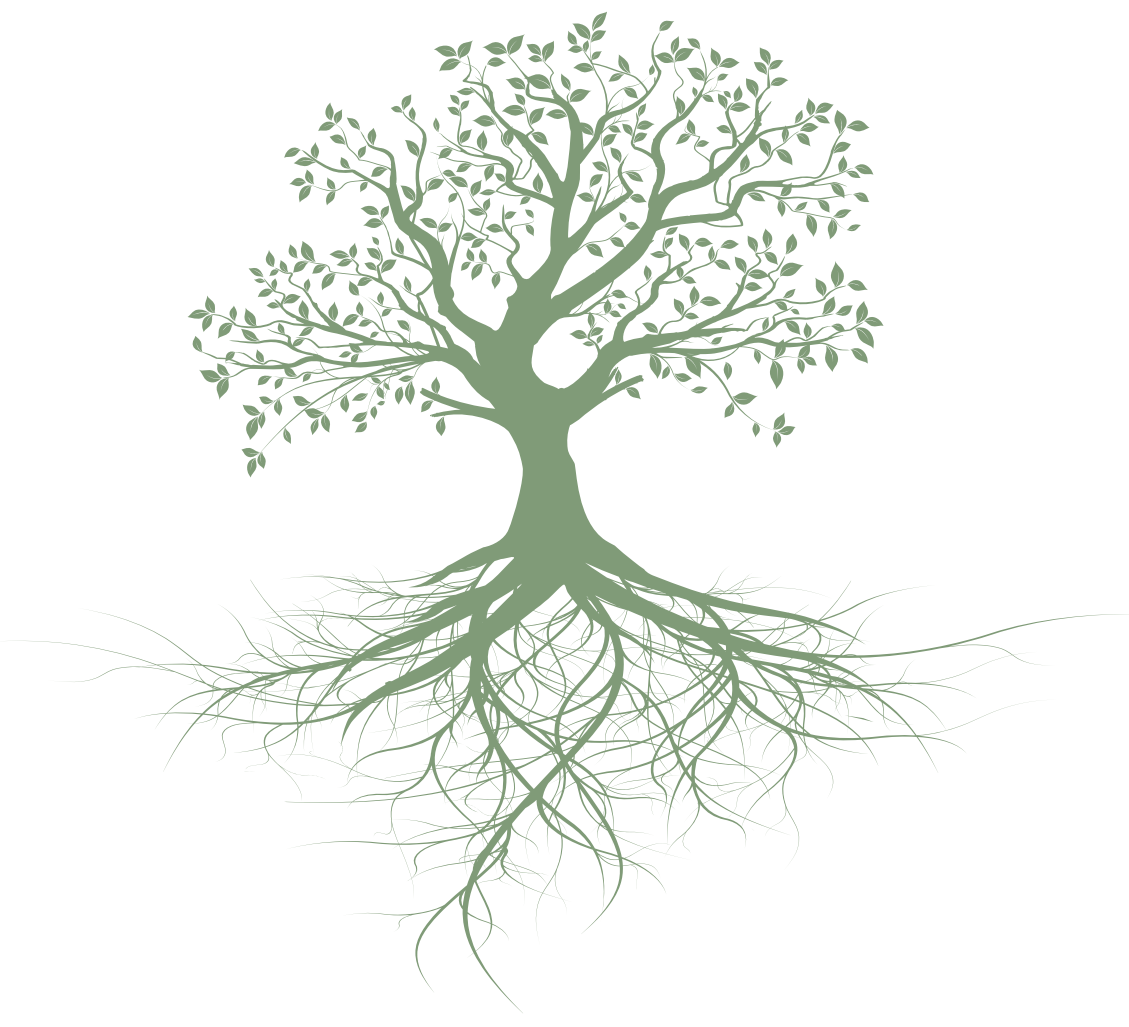

FIGUUR 2.1 Grondmotieven als het wortelgestel van een boom.

Grondmotieven worden wel vergeleken met het wortelstelsel van een boom. (fig. 2.1) In het dagelijks leven zie je stam, takken en loof van een boom en zijn de wortels aan het zicht onttrokken. Dat neemt niet weg dat juist die wortels voor stabiliteit en groei zorgen. Wat zichtbaar is in cultuur en samenleving wordt bepaald en gedragen door de religieuze grondmotieven van een samenleving. Elke cultuur en theorie heeft zijn visie op de werkelijkheid die gebaseerd is op veronderstellingen die als gegeven beschouwd worden en niet te beargumenteren zijn. Sterker nog, ze worden veelal niet bediscussieerd en het is soms zelfs een taboe om ze te bevragen. Het zijn heilige grondmotieven waaraan niet getornd mag worden.

Dooyeweerd onderscheidt vier religieuze grondmotieven en daarmee vier achtereenvolgende perioden in de geschiedenis. Hij wijst er daarbij op dat de opkomst van een nieuw grondmotief als leidende macht niet betekent dat een voorgaand motief volledig verdwijnt, maar wel meer in het defensief wordt gedrongen. Grondmotieven uit voorgaande perioden 
kunnen echter wel in de cultuur blijven doorwerken. In de Griekse en Helleense Oudheid domineerde volgens Dooyeweerd het motief van vorm en materie, in de periode kort na het begin van de christelijke jaartelling het Bijbelse motief van schepping, zondeval en verlossing, in de Middeleeuwen het Rooms-Katholieke motief van natuur en genade, en vanaf de Renaissance het humanistische motief van natuur en vrijheid.

Interessant is de spanning tussen vrijheid en beheersing die volgens Dooyeweerd in het humanistische motief aanwezig is. Dat motief vindt zijn eerste aanvang in de Renaissance, waarin de wedergeboorte van de nieuwe mens centraal staat. Het geloof in die nieuwe autonome mens is in de loop der tijd steeds sterker geworden en is geradicaliseerd in de huidige postmoderne cultuur met een focus op het individu en zijn autonomie. De mens wordt in het middelpunt gezet en is, om met de dichter Kloos te spreken, 'een God in het diepst van zijn gedachten'.55 De menselijke autonomie is het humanistisch credo. Dat brengt een nieuwe verhouding van die mens tot de wereld en natuur waarin hij leeft met zich mee. De natuur wordt met de sacralisering van de mens als het ware gedesacraliseerd. Ze wordt een middel voor de mensen om te beheersen en te benutten. Dooyeweerd laat zien dat er een spanning is tussen dit beeld van beheersen van de natuur en menselijke vrijheid - ook wel geformuleerd als de spanning tussen het persoonlijkheidsideaal en het wetenschapsideaal. Dooyeweerd concludeert dat in het humanistisch motief het geloof in God vervangen wordt door een geloof in wetenschap en techniek.

In de moderne wereld wordt de spanning tussen deze idealen zichtbaar in het streven naar menselijke vrijheid aan de ene kant en het streven naar maakbaarheid en beheersing met behulp van wetenschap en technologie aan de andere kant. De menselijke vrijheid gaat allerminst vanzelfsprekend samen met wetenschappelijke inzichten en technologische normen voor het goede leven. Medicalisering, disciplinering en paternalisme gaan niet samen met de vrijheid van het individu om zijn leven naar eigen inzicht in te richten. Dat wordt goed zichtbaar in de huidige innovatieve ontwikkelingen in de zorg, zoals zelfmanagement, persoonlijke preventie en leefstijlmanagement. Op basis van wetenschappelijke inzichten en technologische interventies worden maatschappelijke arrangementen ontwikkeld waarin mensen veel vrijheid en verantwoordelijkheid krijgen voor de invulling van hun leven en hun omgaan met gezondheid. Tegelijkertijd worden ze gedisciplineerd door een extern genormeerde 'gezonde' leefstijl en idee van het goede leven. De spanning zit erin dat je zelf mag kiezen wat je wilt, zolang je maar de juiste voorgeschreven evidence based keuze maakt. 
Op basis van het denken van Dooyeweerd ontwikkelde de reformatorische wijsgeer Egbert Schuurman het idee dat technologie in de moderne samenleving in hoge mate wordt voortbewogen door een technologische heilsverwachting..$^{56}$ Deze technologische heilsverwachting is een geseculariseerde versie van de christelijke heilsverwachting. ${ }^{57}$ Het heil wordt niet langer van God verwacht maar van technologie waarmee mensen hun eigen verlossing bewerkstelligen. Schuurmans lijn van denken is tot op zekere hoogte vergelijkbaar met die van de eerder besproken Noble. Beiden laten zien dat religieuze grondmotieven richting geven aan technologische ontwikkelingen. Waar Noble echter technologie wilde ontdoen van zijn religieuze grondmotieven, kiest Schuurman voor een andere weg. Hij wil noch van technologie noch van religie afstand nemen. Meer dan Noble blijkt Schuurman er in de lijn van Dooyeweerd van doordrongen dat religieuze grondmotieven een onvermijdelijk gegeven zijn. Schuurman betwijfelt of de technologische heilsverwachting een vruchtbaar grondmotief is voor de ontwikkeling van technologie, cultuur en samenleving. Techniek is immers een manier om de werkelijkheid te ordenen en vorm te geven en om deze daarmee beter en zinvoller te maken. Dat gebeurt in technologie vaak impliciet en dat maakt ambities, idealen en verwachtingen van technologie onzichtbaar en daarmee lastig bespreekbaar. Schuurman heeft er in zijn werk steeds voor gepleit de grondmotieven die leidend zijn voor technologische ontwikkelingen expliciet te maken en te verbinden aan een normatief kader. Voor hem staat centraal dat technologie dienstbaar gemaakt moet worden aan de instandhouding en vormgeving van een diversiteit aan levensvormen. Voor Schuurman roept een verantwoorde cultuurontwikkeling

'een voorstelling van de cultuur op, die doet denken aan de aarde als een door mensen te beheren tuin in de richting van een "gemeenschapshuis", waarin natuur, techniek en cultuur met elkaar in harmonie zijn en waarin voor ieder die leeft en voor alles wat leeft een zinvolle plaats is.' ${ }^{58}$ 


\subsubsection{HET SACRALE BIJ SZERSZYNSKI}

In lijn met Dooyeweerd en Schuurman heeft ook de filosoof Bronislaw Szerszynski weinig fiducie in Noble's idee van een van religie gezuiverde seculiere technologische cultuur. Het is niet eens zozeer dat hij daar bezwaar tegen heeft, maar hij ziet het als een praktische en principiële onmogelijkheid. Waar Schuurman en Dooyeweerd laten zien dat iedere cultuur religieuze grondmotieven kent, introduceert Szerszynski het concept sacraliteit. Het sacrale is voor Szerzynski het fundamentele frame waarmee de mens zijn ervaringen duidt. Aan de hand van het sacrale maakt duidelijk dat ook de moderne samenleving niet zozeer onttoverd is, noch geseculariseerd of gedesacraliseerd. Er is sprake van een transformatie van de betovering en daarmee niet van het verdwijnen van het sacrale maar van het ontwikkelen van een nieuwe sacrale orde.

In zijn boek Nature, technology and the sacred doet Szerszynski de suggestie om het verhaal van de onttovering van de wereld dan ook niet te lezen als wetenschappelijke theorie, maar als het scheppingsverhaal van de moderne samenleving. Het vormt een mythisch narratief dat helpt om de breuk van de moderniteit met het verleden zichtbaar te maken en het exceptionele karakter van de moderniteit te benadrukken. Het is een mythe om te verkondigen dat er niet meer in mythes geloofd wordt maar dat de modernen vertrouwen op natuurkundige wetten en technologische vindingen. Daadwerkelijke bestudering van de ontwikkeling van de moderniteit maakt echter snel duidelijk, betoogt Szerszynski, dat het moderne scheppingsverhaal complexer is en dat er niet zozeer sprake is van een radicale breuk met het verleden, maar van een transformatie van het sacrale.

Szerszynski geeft een perspectief dat het onttoveringsschisma niet als uitgangspunt neemt voor het beschrijven van de westerse geschiedenis. Hij beschrijft de geschiedenis van de westerse cultuur dan ook niet als een ontwikkeling die haar bestemming bereikte in de onttovering van de moderniteit, maar beschrijft de geschiedenis in termen van transformaties van het sacrale. Hij gebruikt het sacrale:

'to understand the ways in which a range of religious framings are involved in our ideas of and dealing with nature and technology. (...) It is the ground against which particular historical phenomena or ideas appear as intelligible figures. So, for example, rather than particular ordenings of the sacred being a response to a particular experience or understanding of God, 
I would rather see any particular understanding of God (including the idea that there is no God) as a feature of a particular ordening of the sacred, as only intelligible when that order is grasped as a Gestalt.' ${ }^{5}$

Met deze benadering van het sacrale opent Szerszynski een nieuw perspectief op de verwevenheid van religie en cultuur in het algemeen en specifiek op de wisselwerking tussen religie en technologie. Hij merkt op dat het moderne seculiere vaak wordt gezien als iets vanzelfsprekends, als een fenomeen dat geen verklaring nodig heeft, terwijl het sacrale wordt gezien als iets afwijkends, als iets dat wel verklaard moet worden. Hij ontwikkelt daarentegen een symmetrische aanpak, waarin het uitgangspunt is dat iedere cultuur of tijdsgewricht zijn eigen sacraliteit kent. Zo stelt hij de vraag naar het sacrale van de seculiere moderniteit. De moderniteit heeft de werkelijkheid niet zozeer onttoverd, maar de ene betovering (godsdienst) vervangen door een andere (wetenschap). Het sacrale van de moderniteit vinden we in het dominante geloof in de wetenschap en technologie waarin de moderne mens haar vertrouwen stelt. In deze benadering is het seculiere dus een vorm, een religieus frame, van het moderne sacrale. Een religieus frame geeft vorm aan onze ervaring en ons begrip van het sacrale en daarmee aan onze benadering van natuur en technologie.

Szerszynski hecht eraan om de moderniteit niet a priori een speciale status te geven maar te zien als een periode met een eigen bepaalde invulling van het sacrale. In wat hij de Long arc of trancendental religion noemt, beschrijft hij in zes stappen de grote transformaties van het sacrale (zie tabel 2.1) en geeft daarmee een geschiedenis van de Westerse religieuze veranderingen.

Szerszynski geeft geen verklaring in zijn beschrijving van de Long Arc. Hij probeert expliciet afstand te nemen van evolutionaire verklaringen voor the Long arc of trancendental religion. De wereld is wat hem betreft te contingent om er een universele logica in te leggen. Die contingentie is in Szerszynskis betoog weinig zichtbaar. Met het beeld van een grote boog geeft hij op zijn minst een suggestie van logica aan in de ontwikkeling, een boog ontstaat immers niet zomaar. Szerszynski construeert de boog door haar een temporeel begin en een eind te geven en te plaatsen op de grond van de Europese cultuur. In dat opzicht heeft de lange boog dan ook een beperkte reikwijdte. Ze heeft geen aandacht 


\begin{tabular}{|c|c|c|c|}
\hline PERIODE & SACRALE & KARAKTERISTIEKEN & TECHNOLOGIE \\
\hline PRIMAL SACRED & $\begin{array}{l}\text { Integraal onderdeel } \\
\text { van de natuur. }\end{array}$ & $\begin{array}{l}\text { Monistisch; } \\
\text { Gericht op het bewaren } \\
\text { van de duurzame eenheid. }\end{array}$ & $\begin{array}{l}\text { Technologie is geen } \\
\text { onderscheiden } \\
\text { grootheid. }\end{array}$ \\
\hline ARCHAIC SACRED & $\begin{array}{l}\text { Natuurgoden, bijv. } \\
\text { Grieks pantheon. }\end{array}$ & $\begin{array}{l}\text { Monistisch; } \\
\text { Onwetendheid is zonde; } \\
\text { Contemplatie op doel } \\
\text { (telos) van de natuur. }\end{array}$ & $\begin{array}{l}\text { Contemplatieve } \\
\text { houding maakt techné } \\
\text { tot banale materie. }\end{array}$ \\
\hline $\begin{array}{l}\text { MONOTHEISTIC } \\
\text { SACRED }\end{array}$ & God & $\begin{array}{l}\text { Dualisme van natuur en } \\
\text { transcendente God; } \\
\text { Bemiddeling noodzakelijk; } \\
\text { Focus op hiernamaals; } \\
\text { Het morele kwaad is } \\
\text { zonde. }\end{array}$ & $\begin{array}{l}\text { Vita activa creëert } \\
\text { ruimte om technologie } \\
\text { als middel te } \\
\text { ontwikkelen. }\end{array}$ \\
\hline $\begin{array}{l}\text { PROTESTANT } \\
\text { SACRED }\end{array}$ & God & $\begin{array}{l}\text { Dualisme; } \\
\text { Persoonlijke relatie met } \\
\text { God; } \\
\text { Focus op hiernamaals; } \\
\text { Inspiratie voor vrede en } \\
\text { recht: sociale initiatieven. }\end{array}$ & $\begin{array}{l}\text { Vita activa; } \\
\text { Gods boek der natuur } \\
\text { en technologie als } \\
\text { instrumenten om de } \\
\text { natuur te temmen. }\end{array}$ \\
\hline MODERN SACRED & De mensheid & $\begin{array}{l}\text { Immanent; } \\
\text { Collectieve kosmologie; } \\
\text { Samenleven hier en nu; } \\
\text { Creëren van hemel op } \\
\text { aarde. }\end{array}$ & $\begin{array}{l}\text { Technologische } \\
\text { verlossing van aardse } \\
\text { lasten. }\end{array}$ \\
\hline $\begin{array}{l}\text { POSTMODERN } \\
\text { SACRED }\end{array}$ & Het individu & $\begin{array}{l}\text { Immanent; } \\
\text { Individuele spiritualiteit en } \\
\text { zingeving; } \\
\text { Persoonlijk patchwork van } \\
\text { overtuigingen en rituelen. }\end{array}$ & $\begin{array}{l}\text { Technologische } \\
\text { verlossing gericht op } \\
\text { persoonlijke groei en } \\
\text { verlichting. }\end{array}$ \\
\hline
\end{tabular}


voor de veranderingen van het sacrale in bijvoorbeeld Afrikaanse ${ }^{60}$ en Aziatische ${ }^{61}$ culturen en de interacties tussen deze culturen en de Europese. Had hij dat wel gedaan dan had hij naast de richting ook de contingentie van de veranderingen kunnen laten doorklinken in zijn betoog. ${ }^{62}$ Daarmee zou een verscheidenheid aan long arches kunnen worden geconstrueerd. Szerszynski had dan nog breder kunnen laten zien dat het sacrale van alle plaatsen en tijden is, waaronder in de Europese technologische cultuur van vandaag de dag.

Voor Szerszynski is de secularisatie een speciale uitingsvorm van het sacrale. Met de secularisatie is het sacrale volledig immanent geworden, maar daarmee niet minder heilig of minder aanwezig. Op basis van Szerszynski's Long arc kunnen we het volgende concluderen over het sacrale in een technologisch cultuur: religie is dood, lang leve religie!

Door het idee van moderniteit als seculier en onttoverd van Weber werd onderzoek naar de verwevenheid van technologie en religie min of meer irrelevant. Religie was immers gedoemd tot uitsterven, mede door de technologische ontwikkelingen. Met Szerszynski symmetrische benadering van het sacrale blijkt onderzoek naar de relatie tussen technologie en het sacrale allerminst obscuur of irrelevant. Szerszynski heeft oog voor de blijvende rol van het sacrale, ook in de (post) moderne technologische cultuur en opent daarmee het veld voor onderzoek naar de verwevenheid van technologie en religie. Szerszynski's benadering levert mooie inzichten in de technologische cultuur in algemene zin op en een opening van het veld van technologie en religie. Hij geeft echter weinig inzicht in de verhoudingen en dynamiek tussen technologie en religie in de praktijk van het leven van vandaag de dag.

\subsubsection{HET SUBLIEME IN EEN TECHNOLOGISCHE CULTUUR}

De cultuurstudies van Dooyeweerd en Szerszynski die een paar millennia van de westerse cultuur omvatten, maken nieuwsgierig naar een meer verfijnd inzicht in de relatie tussen technologie en religie in de huidige westerse technologische cultuur. Hoe kunnen we inzoomen op de

60 Ejizu, Readings on religion \& culture in Africa.

61 Lim, Mediating piety: technology and religion in contemporary Asia.

62 De verwevenheden tussen technologie en religie kent vele varianten. Zo is (het ontwikkelen van) technologie in de Kikuyu mythologie een godgegeven vaardigheid, zoals het volgende citaat illustreert: 'For your faith in me (Mogoi, the divider), I will give you good advice about how to get better tools, not only for sacrifices, but also for your general use. I will make you the masters of your animals with new tools, ...' Kenyatta, Facing Mount Kenya: the traditional life of the Gikuyu, 70. 
verwevenheid van technologie en religie vandaag de dag in een wereld die hervormd is door technologie en waarin religie transformeert? De sociologen Émile Durkheim en Robert N. Bellah en de historicus David Nye helpen ons daarbij.

Voor verschillende grondleggers van de sociologie aan het begin van de twintigste eeuw was religie slechts een illusie of een valse verklaring voor natuurverschijnselen. Karl Marx noemde religie 'opium van het volk' ${ }^{63}$ Religie zou een verdovingsmiddel zijn dat mensen het zicht ontneemt op de economische krachten in de samenleving en de werkelijke klassenstrijd. Voor Max Weber was religie een manier voor mensen om grip te krijgen op de wereld en het kwaad, en uiting te geven aan de behoefte aan verlossing. Religie is voor Weber een betovering, die mensen motiveert. Door de modernisering zou de samenleving volgens Weber rationaliseren, onttoveren en seculariseren. ${ }^{64}$

Voor een andere grondlegger van de sociale wetenschappen, Émile Durkheim, is religie meer dan opium of betovering; hij kon niet geloven dat religie eeuwen zou kunnen overleven op basis van valse voorstellingen. Voor Durkheim is religie een samenhangend systeem van geloof en rituelen rond het sacrale en een essentieel, functioneel en waardevol onderdeel van elke samenleving. De samenleving is een hoogstaande zaak voor Durkheim en hij maakte zich aan het begin van de twintigste eeuw zorgen over haar stabiliteit vanwege modernisering en secularisering. Durkheims interesse in religie kwam voort uit zijn zoektocht naar het verbindende element in een samenleving. Hij komt tot de conclusie dat religie in zekere zin de samenleving zelf is. ${ }^{65} \mathrm{Hij}$ trekt die conclusie op basis van zijn onderzoek naar het totemisme van de Aboriginals in Australië. Hij verwachtte dat hij in deze vroege primitieve cultuur de essentiële elementen van religie kon ontrafelen. In de Aboriginal cultuur is de totem als een godheid te beschouwen. Tegelijkertijd staat diezelfde totem ook symbool voor de clan. Durkheim trekt op basis daarvan de conclusie dat als de totem zowel symbool voor de goddelijkheid is als ook voor de samenleving, dat god en samenleving dan ook één en dezelfde zijn. De God van de clan, in de vorm van een totem, is een gedaanteverwisseling en verheerlijking van de clan zelf. Religie verbindt het individu aan de groep en is daarmee de basis voor een groep of een samenleving: 'the idea of society is the soul of 
religion'. ${ }^{66}$ Voor Durkheim is de samenleving de superieure morele macht die de gelovigen inspireert. Religie heeft bij Durkheim een zeer hoge symbolische waarde: de totem symboliseert de samenleving en door de totem oefent de samenleving kracht uit. In de totem ziet Durkheim 'only society transfigured and symbolically expressed' ${ }^{67}$. Met het gelijkstellen van de totem aan de samenleving stoot Durkheim het goddelijke van de troon en plaatst hij het sacrale tegelijkertijd terug op die troon als de basis onder elke vorm van samenleven. ${ }^{68}$

Durkheim laat scherp zien hoe religie onlosmakelijk verbonden is met een samenleving. Ze biedt een samenleving een natuurlijke manier om te reflecteren op haar transcendentale vermogen. Daarnaast vormt religie de basis voor sociale samenhang en verbondenheid. Religie is tegelijkertijd de spiegel en het cement voor de samenleving. Ze geeft betekenis en richting aan de samenleving en zorgt voor verbondenheid zodat die samenleving kan bestaan. Volgens Durkheim maakt religie het voor een individu mogelijk boven zichzelf uit te stijgen. In die transcendentie kan hij eigenbelangen overstijgen en tot een hogere moraal en nobeler leefstijl komen. De morele laag van religie is bij Durkheim essentieel. Hij legt een intrinsiek verband tussen religie en moraal. ${ }^{69}$ Religie is een morele autoriteit en traditie die het individu met de samenleving verbindt. Tegelijkertijd wordt religie door het individu ook ervaren als een sacraal onderdeel van zijn wezen, een inspiratiebron die levenskracht, zin en genade geeft. Religie geeft structuur en kaders waarbinnen mensen zich bewegen en ze geeft mensen tegelijkertijd kracht, vertrouwen en inspiratie om nieuwe wegen te bewandelen. De aantrekkingskracht van religie schuilt in de structuur die ze biedt en tegelijkertijd in haar bevrijding van diezelfde structuren. In de ogen van Durkheim zijn de esthetische en recreatieve kant van religie een essentieel onderdeel van religie.

66 Durkheim, 314.

67 Durkheim, 314.

68 Durkheims sociologische analyse mondt uit in een ontologische positionering. Die positionering grondvest religie niet in een menselijke eigenschap, noch in een metafysisch fenomeen zoals in andere ontologische religieuze theorieën aan het begin van de twintigste eeuw. (Lynch, The sacred in the modern world, 10.) Durkheims begrip van de sociale bron van religie vooronderstelt dat de kracht en het belang van religie voortkomen uit een universeel gedeelde menselijke ervaring, de ervaring van het participeren in de zichzelf overstijgende werkelijkheid van de sociale groep. (Lynch, 26-27.) Een dergelijke ontologische vooronderstelling is echter onnodig en schiet al snel te kort in haar empirische onderbouwing. Ik volg Durkheims ontologie dan ook niet, maar neem methodologische relativistische positie in om te onderzoeken hoe bepaalde religieuze ervaringen worden geconstrueerd. (Bijker, 'How is technology made? That is the question!') 
'Religion transports us in another world in which our imagination is more at ease. It constructs arena's for play, art and all those things that renew the spirit worn down by the constraints of daily labour.' ${ }^{70}$

Religie is kortom een bron van inspiratie en moreel kader voor reflectie op leven en samenleven. Ze maakt het mogelijk om een banaal individualisme te overstijgen en vormt de uiterste basis voor een morele gemeenschap en voor recreatie en innovatie.

Verder bouwend op het werk van Durkheim ontwikkelde de socioloog Robert N. Bellah het concept civil religion. ${ }^{71}$ In zijn artikel Civil religion in America ${ }^{72}$ laat hij zien dat in de Verenigde Staten sprake is van een burgerlijke religie die een samenbindende kracht vormt in de samenleving. Amerikanen delen een aantal fundamentele waarden en overtuigingen, die tot uiting komen in teksten, speciale feestdagen en rituelen. Illustratief daarvoor is de sacrale status die de Amerikaanse onafhankelijkheid krijgt in teksten en gedeelde gebruiken. De Constitution en de Declaration of Independence worden met eerbied behandeld en in die teksten wordt verwezen naar Godgegeven en onvervreemdbare rechten. De onafhankelijkheid wordt ook jaarlijks gevierd op de Fourth of July, de nationale feestdag met haar eigen formele en informele rituelen, zoals schoolkinderen die met de hand op het hart het volkslied zingen en het gezamenlijk bewonderen van de vuurwerkshows.

Civil religion is impliciete religie. ${ }^{73}$ Ze wordt niet expliciet als religie benoemd en ze bestaat voor de burgers ook probleemloos naast hun persoonlijke confessionele godsdienst. Bij gelegenheid trekken die twee zelfs samen op. Zo wordt in Nederland in veel kerken het Wilhelmus gezongen op Koningsdag en wordt de Amerikaanse president ingezworen met zijn hand op de Bijbel. Civil religion bouwt deels voort op godsdienstige tradities maar staat daar tegelijkertijd los van. Er wordt door Amerikaanse presidenten wel verwezen naar God, maar vrijwel nooit naar Mozes, Mohammed, Jezus of andere personages uit specifieke godsdiensten. Civil religion heeft tegelijkertijd een God gegeven en goddeloos karakter. Bellah citeert de Amerikaanse president Dwight Eisenhower die deze dubbelzinnigheid op treffende wijze verwoord heeft

\footnotetext{
70 Durkheim, The elementary forms of religious life, 282.

71 Het begrip 'civil religion' wordt voor het eerst gebruikt Jean-Jacques Rousseau in zijn verhandeling The Social Contract uit 1762 . 
met zijn uitspraak: 'Our government makes no sense unless it is founded in a deeply felt religious faith, and I don't care what it is."74

De historicus David Nye laat in zijn boek The American Sublime zien dat technologie een belangrijk onderdeel is van de Amerikaanse civil religion. Nye focust bij the American sublime op de religieuze ervaring. Een dergelijke sublieme religieuze ervaring wordt door de theoloog en onderzoeker Rudolf Otto een numineuze ervaring genoemd. Het numineuze is tegelijkertijd geheimzinnig en krachtig, het roept vrees en fascinatie op..$^{75}$ Voor Immanuel Kant omvatte het sublieme zowel pijn als genot. Tegenover het sublieme ervaart men zwakte en onbeduidendheid maar tegelijkertijd herpakt men zich daarbij door het ontwikkelen van een superieur gevoel van grootsheid omdat de geest in staat is om iets te omvatten dat de zintuigen overstijgt. De natuur is door de eeuwen heen als een belangrijke bron voor het sublieme gezien. Johannes Calvijn geloofde al dat God ontdekt kon worden in de natuur. De natuur is de spiegel van Gods werk. ${ }^{\prime 6}$ Nye beschrijft het sublieme als volgt:

'The sublime is an essentially religious feeling, aroused by the confrontation with impressive objects, such as Niagara Falls, the Grand Canyon, the New York Skyline, the Golden Gate bridge, or the earth-shaking launch of a space shuttle.' ${ }^{77}$

Nye laat zien dat het sublieme in de Amerikaanse cultuur niet alleen in de natuur maar juist ook in technologie wordt gevonden. Het technologisch sublieme is in de Verenigde Staten onlosmakelijk verbonden met de civil religion.

De sublieme ervaring is niet zozeer een individuele ervaring. Haar kracht schuilt volgens Nye in haar collectieve beleving en vormgeving. Het sublieme is een sociale constructie. Bij gebrek aan culturele ankerpunten, zoals een koninklijke familie, nationale kerk of historische plaatsen van nationaal belang, richten de Amerikanen zich begin negentiende eeuw op hun unieke landschapspunten als karakteristieken van de nationale aard van de Amerikaanse samenleving. ${ }^{78}$ Plaatsen zoals de Niagara-watervallen, de Natural Bridge en de Grand Canyon werden een representatie van de nationale aard. Toeristische tochten kregen het

\footnotetext{
74 Bellah, 'Civil religion in America', 3.

75 Otto, Het heilige: over het irrationeele in de idee van het goddelijke en de verhouding ervan tot het rationeele. 76 Nye, American technological sublime, 5.

77 Nye, XIII.

78 Nye, 25.
} 
karakter van pelgrimages. De natuurgebieden werden ook steeds meer op die pelgrimbezoekers ingericht en het sublieme werd al snel geen overrompelende ervaring meer maar een gepland en gegarandeerd onderdeel van de reis, dat vooraf al uitgebreid beschreven en besproken was. De sublieme ervaring ontwikkelde zich tot een collectieve en populaire sublieme bestemming voor gevoelens van nationalisme. ${ }^{79}$ Het Amerikaanse publiek vierde het sublieme van de diepste waterval, de grootste canyon, maar ook het langste treinspoor. Met een gevoel van trots constateerde men dat zoiets subliems ongekend was in Europa. Het was America first en Make America great again avant la lettre.

Technologie werd steeds meer een onderdeel van the American dream en civil religion. Het in 1830 geopende Erie Canal van Albany naar Buffalo was één van de eerste 'sublieme' technologische objecten. Het vormde zowel sociaal als technisch een belangrijke verbinding in de samenleving en het landschap, maar werd ook een toeristisch hoogtepunt waar het Amerikaanse technologisch vernuft werd gevierd. Tegelijkertijd werd het kanaal gezien als een product van de Amerikaanse democratie en als een voorbode van de bestemming van de natie. Het was het toonbeeld van wat a free people allemaal vermag. In het Amerikaanse sublieme werden door technologie gemedieerde individuele sublieme ervaringen getransformeerd in een civil religion van nationaal zelfbewustzijn. ${ }^{80}$

Durkheims benadering van religie opent de deur voor een antropologische benadering van religie, waarin de religieuze praktijk centraal staat. In lijn met Durkheims benadering wijst Bellah er met zijn studie naar de American civil religion op dat zo'n benadering praktisch mogelijk is en inhoudelijk nieuwe inzichten geeft in de dynamiek en constructie van religie in de moderne seculiere technologische cultuur. Nye toont in aanvulling daarop aan dat technologie en religie in die cultuur samen optrekken. Waar Szerszynski liet zien hoe technologie en religie door de eeuwen heen met elkaar verweven zijn gebleven, wijst Nye erop dat die nauwe verbondenheid ook vandaag de dag nog onmiskenbaar aanwezig is. Technologie heeft in de Amerikaanse samenleving en civil religion een grote symbolische waarde. Technologie is onderdeel van die civil religion en geeft vorm aan de civil religion.

De vraag die opkomt is of ook het omgekeerde geldt: heeft de religie ook invloed op de technologische ontwikkeling? En zo ja, is die invloed ook vandaag de dag nog zichtbaar in een technologische cultuur, niet alleen op een symbolisch niveau maar ook in de concrete praktijk? Om dat 
te onderzoeken introduceer ik drie perspectieven om onderzoek te doen naar religie in de technologische cultuur en presenteer mijn onderzoeksvragen.

\subsection{PERSPECTIEVEN VOOR ONDERZOEK IN EEN TECHNOLOGISCHE CULTUUR}

In deze paragraaf worden enkele theoretische perspectieven voor onderzoek naar de verwevenheden van technologie en religie beschreven. De theorieën worden gebruikt om tot een kader te komen voor het onderzoeken van het vrijwel onontgonnen terrein van technologie en religie. Ze werken als perspectieven op het onderzoeksterrein. ${ }^{81} \mathrm{Ik}$ put uit verschillende niet noodzakelijk commensurabele en in ieder geval niet veelvuldig gecombineerde onderzoekstradities van het constructivistisch technologieonderzoek, de religiewetenschappen en de reformatorische wijsbegeerte.

Om tot een vertrekpunt te komen en een heuristiek te ontwikkelen worden drie theoretische perspectieven verkend: het Triple I model (TIM) van Verkerk; het Social Construction of Technology-programma (SCOT) zoals ontwikkeld door Bijker en tenslotte Durkheims sociale theorie over het sacrale voor onderzoek naar religie en samenleving. Deze theoretische perspectieven hebben zich bewezen in het onderzoek naar religie, technologie of samenleving en zijn complementair. Met behulp van deze theoretische perspectieven probeer ik dieper inzicht te ontwikkelen over de rol van religie in de technologische cultuur en op basis daarvan een bijdrage te leveren aan theorievorming.

\subsection{TRIPLE I MODEL - EEN PERSPECTIEF OP DE MODALITEITEN VAN TECHNOLOGISCHE PRAKTIJKEN}

Het Triple I model (TIM) komt voort uit de traditie van de Reformatorische wijsbegeerte, tegenwoordig Christelijke wijsbegeerte genoemd, die zich ontwikkelde vanaf het begin van de $20^{e}$ eeuw. ${ }^{82} \mathrm{Ze}$ sloot aan bij de ordening van de moderne wetenschappelijke disciplines, ${ }^{83}$ maar maakte ook duidelijk dat die disciplinaire orde gegrondvest was in voorwetenschappelijke grondmotieven. Daarmee werd afstand genomen 
van de destijds heersende opinies voorkomend uit de Verlichting waarin het verstand als vertrekpunt werd genomen. De reformatorische wijsgeer Dooyeweerd ontwikkelde de leer van de grondmotieven, die hiervoor al werd besproken. Daarmee neemt hij afstand van een scientistisch en rationalistisch wereldbeeld en schept hij ruimte om na te denken over de rol van inspiratie, overtuigingen, hoop en verlangens in wetenschap, technologieontwikkeling en innovatie.

\begin{tabular}{|c|c|}
\hline $\begin{array}{l}\text { ASPECTEN OF } \\
\text { MODALITEITEN }\end{array}$ & ZINKERN \\
\hline Aritmetische & Discrete kwantiteit, hoeveelheid \\
\hline Ruimtelijke & Uitgebreidheid, continue uitgebreidheid \\
\hline Kinematische & Beweging, continue beweging \\
\hline Fysische of fysisch-chemische & Energie, interactie, wisselwerking \\
\hline Biotische & Leven, organische, vegetatieve, vitale \\
\hline Psychische & Gevoel, sensitieve, zintuiglijke \\
\hline Analytische & Logische, redelijke, analytische onderscheiding, bewuste onderscheiding \\
\hline Formatieve & Beheerste vorming, vrijheidsmacht, macht, heerschappij \\
\hline Talige & Duiding, betekenis, symbolische betekenis \\
\hline Sociale & Omgang, verkeer, verbondenheid, samenhang \\
\hline Economische & Beheer van schaarse goederen, rentmeesterschap, productiviteit \\
\hline Esthetische & Harmonie, schoonheid, zinspeling, vol schakering \\
\hline Juridische & Vergelding, gerechtigheid, recht \\
\hline Morele & Liefde, zorg, trouw, dienstbaarheid \\
\hline Pistische & Transcendentale zekerheid, betrouwbaarheid, geloof, heilige, vastheid \\
\hline
\end{tabular}




\subsubsection{ASPECTEN EN INDIVIDUALITEITSSTRUCTUREN}

Naast de leer van de grondmotieven ontwikkelde Dooyeweerd ook de theorie van de individualiteitsstructuren en de aspecten- of modaliteitenleer. Hij maakt in zijn denken een onderscheid tussen gehelen en modaliteiten of aspecten. Voorbeelden van wat hij als een geheel beschouwd zijn een mens, een organisatie, een auto, een computer, een steen enzovoorts. Een geheel heeft een eigen karakter. Het geheel functioneert in wat hij noemt verschillende modaliteiten of aspecten. Het begrip modaliteit komt van het Latijnse modus, een manier van zijn. Hij spreekt van vijftien modaliteiten, ofwel vijftien manieren van zijn (zie tabel 2.1) en geeft daarmee een ontologisch kader.

Deze modaliteiten zijn uniek en niet te herleiden tot elkaar of zoals Dooyeweerd het formuleert: de modaliteiten hebben ieder een eigen unieke zinkern. De modaliteiten zijn niet los verkrijgbaar maar altijd inherent aan een geheel. Zo heeft een mens voedsel nodig (de biologische modaliteit), denkt na (de analytische modaliteit) en heeft contact met andere mensen (de sociale modaliteit), is zorgzaam (de morele modaliteit) en draagt heilige grondmotieven en transcendentale zekerheden met zich mee (pistische modaliteit). ${ }^{85}$ De biologische kant van een mens is echter niet los te maken of te isoleren van zijn sociale, analytische of pistische ${ }^{86}$ modaliteiten: een mens is een geheel. Technologie is voor hem ook een geheel en ook daar kunnen de verschillende aspecten ontsloten worden. Dat ligt voor de hand voor aspecten als het aritmetische, ruimtelijke en fysische en het is ook goed voorstelbaar dat technologieën een economisch (want verkoopbaar), esthetisch (het design) en juridisch (aansprakelijkheid) aspect ontsluiten. Met het pistische aspect vraagt Dooyeweerd echter ook aandacht voor de religieuze modaliteit van technologie.

Dooyeweerd betoogt verder dat elk geheel een eigen identiteit of individualiteitsstructuur heeft die beschreven wordt door de kwalificerende functie. Dat is het aspect dat centraal staat in de ontwikkeling en werking van een praktijk, organisatie of technologie. De identiteit van een onderneming wordt bepaald door het economische aspect, van een kerk door het pistische aspect, en van een ziekenhuis door het morele aspect. De identiteit van een praktijk wordt bepaald door de kwalificatie van het primaire proces van die praktijk ofwel van de bestaansgrond van die praktijk. 


\subsubsection{IDENTITEIT, INTERESTS EN IDEALEN}

Deze theorieën van de grondmotieven, aspectenleer en indvidualiteitsstructuren hebben de basis gelegd voor het Triple I Model ${ }^{87}$ zoals ontwikkeld door Maarten Verkerk. ${ }^{88}$ Het TIM is een middel om professionele praktijken te analyseren, dan wel te ontwikkelen. Om een praktijk te doorgronden vraagt Verkerk in het TIM aandacht voor drie I's van Identiteit, Interests ${ }^{89}$ en Idealen (zie fig. 2.2).

\section{Identiteit}

De identiteit van de praktijk wordt bepaald door de intrinsieke waarden van de praktijk, zoals de zorg bepaald wordt door de zorgen voor de ander. Het is de kwalificerende functie van die praktijk.

De identiteit wordt gedragen door de centrale actoren, die inherent zijn aan de betreffende praktijk. In de zorg zijn dat de patiënten en de zorgprofessionals die met hun waarden vormgeven aan de identiteit van de praktijk. Zonder hen is een zorgprakijk niet mogelijk. Hun zorgwaarden zijn door hun beroepsverenigingen en koepels geëxpliceerd in beroepscodes en de artseneed. Zorgprofessionals zijn de dragers van de kwalificerende functie van de praktijk.

\section{Interests}

Naast de inherente actoren van een praktijk zijn er andere betrokkenen en belanghebbenden bij een praktijk. Zij faciliteren het primaire proces en oefenen daar invloed op uit vanuit hun eigen overtuigingen, verantwoordelijkheden en belangen. Zo spelen in de zorg zorgverzekeraars een financiële rol, zorgt de overheid voor juridische kaders en de controle daarop (bijvoorbeeld via de Inspectie voor Gezondheidszorg) en geven farmaceuten en leveranciers van ICT en medische technologie met hun producten en diensten mede vorm aan de zorgpraktijk.

87 Het TIM heeft nauwe verwantschap aan het Normatieve Praktijk Model (Hoogland en Jochemsen, 'Professional autonomy and the normative structure of medical practice'.; Vries en Jochemsen, The normative nature of social practices and ethics in professional environments.)

88 Verkerk, 'A philosophy-based "toolbox" for designing technology: The conceptual power of Dooyeweerdian philosophy'; Harmsen en Verkerk, Process Intensification.

89 Ik kies ervoor de Engelse term interests te gebruiken en deze niet te vertalen naar de Nederlandstalige term belangen. Zo blijft de kracht en logica van de naam Triple I model zichtbaar in de tekst. 


\section{Idealen}

Iedere praktijk ontwikkelt zich in een maatschappelijke context met haar eigen culturele grondmotieven of basic beliefs..$^{90}$ In het maatschappelijk debat en de publieke opinie worden praktijken besproken en beoordeeld. Dat geldt zeker voor de zorgpraktijk waar technologische en culturele ontwikkelingen voor continu debat en dynamiek zorgen, zoals in debatten over levenseindezorg, ${ }^{91}$ kloneren ${ }^{92}$ en persoonlijke preventie..$^{93}$ De grondmotieven van een cultuur zijn het wortelgestel van een boom, ze zorgen voor verankering en groei. Zo zijn in de Nederlandse zorg individuele autonomie en gezondheid diepgewortelde waarden.

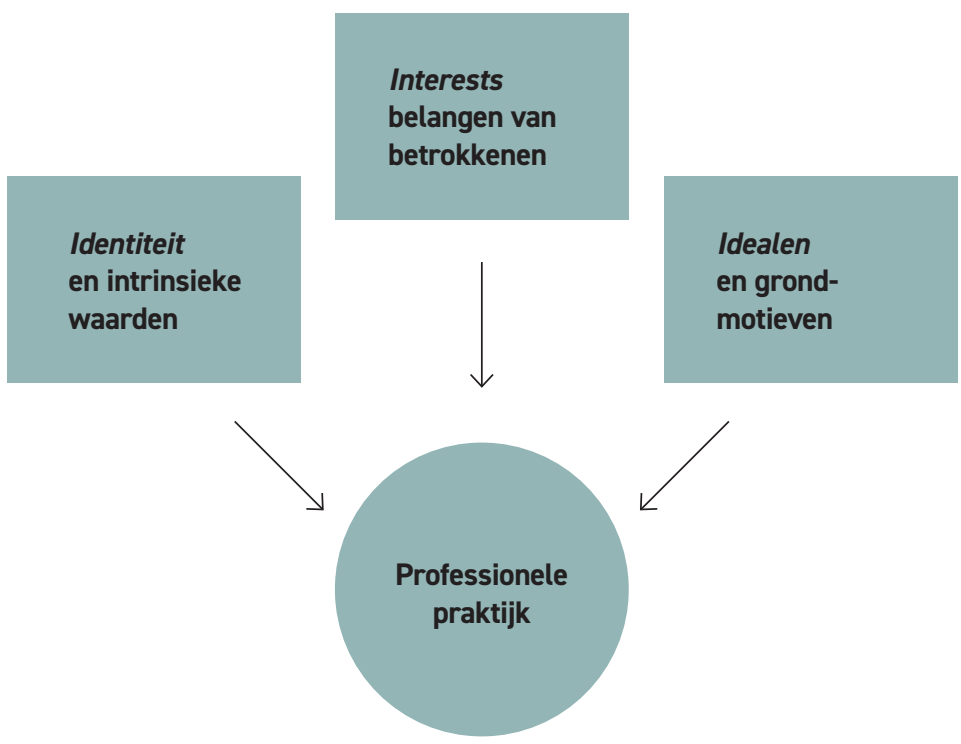

FIGUUR 2.2 Schematische weergave van het Triple I model. ${ }^{94}$

90 Verkerk, 'A philosophy-based "toolbox" for designing technology: The conceptual power of Dooyeweerdian philosophy'.

91 Boer, Verkerk, en Bakker, Over(-)behandelen : ethiek van de zorg voor kwetsbare ouderen.

92 Swierstra, Kloneren in de polder het maatschappelijk debat over kloneren in Nederland, februari 1997 - oktober 1999.

93 Vries, Horstman, en Haveman, Politiek van preventie: normatieve aspecten van voorspellende geneeskunde. 94 Verkerk e.a., 'Professional practices and user practices: an explorative study in health care'. 
In praktijken worden alle aspecten of modaliteiten gericht op de identiteit van het primaire proces. In de terminologie van Dooyeweerd: alle aspecten of modaliteiten worden ontsloten onder invloed van de kwalificerende functie van de praktijk, de belangen van de stakeholders en de maatschappelijke idealen of tijdsgeest. De kwalificerende functie geeft richting aan die ontsluiting. Zo hebben een wandelstok en een Nordic walking stick dezelfde basale functie (ondersteuning bij het wandelen), maar tegelijkertijd een heel verschillende ontsluiting. Een Nordic walking stick is gericht op sportieve activiteit van mensen (en heeft training als kwalificerende functie) en een wandelstok is gericht op ondersteuning van mensen van wie de vitaliteit en stabiliteit afneemt (waarbij zorg de kwalificerende functie is).

De drie perspectieven die het TIM op de praktijk geeft, zijn behulpzaam bij het beschrijven van een gevestigde praktijk, maar zijn ook nuttig om de dynamiek en veranderingen in een praktijk te analyseren. Veranderingen in de waarden van actoren of cultuur bepalen hoe een praktijk zich ontwikkelt. In de zorgpraktijk is goed zichtbaar hoe met de ontwikkeling en implementatie van nieuwe technologie in een praktijk zich ook nieuwe taal ${ }^{95}$, normen en waarden ontwikkelen, ${ }^{96}$ terwijl culturele vragen en veranderingen zorgen voor heroverweging van praktijken. Door oog te hebben voor idealen, interests en identiteit wordt inzicht verkregen in de dynamiek van een praktijk.

\subsection{SOCIAL CONSTRUCTION OF TECHNOLOGY - EEN PERSPECTIEF OP SOCIO-TECHNISCHE VERANDERING}

Om te komen tot een theoretisch kader en instrumentarium voor onderzoek naar de verwevenheid van technologie en religie in de praktijk maak ik gebruik van inzichten uit het technologieonderzoek en de religiewetenschappen. Vertrekpunt is het werk van de technieksocioloog Wiebe Bijker en zijn theorie over socio-technische verandering genaamd Social Construction of Technology (SCOT).

$\mathrm{SCOT}$ is een benadering om technologische verandering uit heden of verleden te bestuderen. Zoals in de naam zichtbaar wordt, staat SCOT in een constructivistische onderzoekstraditie. Dat betekent dat ze de 
werking van technologische artefacten niet als intrinsieke eigenschap van het artefact ziet maar als resultaat van een ontwikkelingsproces. Dat een technologie werkt is daarmee niet langer de verklaring voor het succes van een technologie, maar moet zelf verklaard worden. De centrale vraag is: hoe wordt technologie gemaakt?97 Om die vraag te beantwoorden wordt het constructieproces onderzocht en daarbij is er aandacht voor onder meer sociale, juridische en technische zaken.

\subsubsection{ONDERZOEKSAANPAK EN THEORIE}

SCOT biedt zowel een onderzoekaanpak als een theorie over technologische ontwikkeling en de verwevenheid van technologie en samenleving. Met SCOT werd eind jaren tachtig van de twintigste eeuw afstand genomen van het technologisch determinisme. Dat laatste stelde dat 1) technologie zich autonoom ontwikkelt en 2) dat technologie in sterke mate de maatschappelijke ontwikkelingen bepaalt. Die autonomie zou technologische ontwikkeling min of meer ongevoelig maken voor politiek en beleid. De claim binnen SCOT is dat technologisch determinisme voortkomt uit een onderzoeksstrategie waarin een teleologisch, lineair en eendimensionaal beeld van technologische ontwikkeling wordt gebruikt. Dat de technologie werkt moet echter niet als verklaring voor haar succes worden opgevoerd, de uitdaging is om te verklaren hoe het komt dat de technologie werkt. Belangrijk uitgangspunt daarbij is het symmetrie-principe: de werking en het falen van een technologie moeten op vergelijkbare wijze verklaard worden. Technologie kent geen eigen intrinsieke logica, we kunnen haar niet begrijpen door alleen technische factoren. Technologie krijgt mede vorm en betekenis door sociaal-culturele factoren. We moeten technologische ontwikkelingen dan ook beschrijven in termen van sociale constructies. Het symmetrieprincipe wordt verder uitgewerkt in de metafoor van het seamless web, een naadloos netwerk van technische en sociale factoren. Daarbij is niet op voorhand en los van de context te zeggen of een kwestie als technisch of sociaal moet worden begrepen. Het gaat juist over de mutual shaping, de wederzijdse vormgeving of de co-constructie van technologie en samenleving. De activiteiten van technologie-ontwikkelaars zijn in dat kader het beste te omschrijven als heterogeneous engineering. ${ }^{98}$ Centraal staat het tot een werkend systeem integreren van ongelijksoortige zaken als techniek, cultuur, wetgeving, economie en, zoals ik hier zal betogen, religie. 
In zijn boek Of Bicycles, bakelites and bulbs, towards a theory of sociotechnical change ${ }^{99}$ werkt Bijker een aanpak voor onderzoek naar de constructie van technologie uit. Hij bouwt die aanpak op in drie stappen:

1. Deconstructie: beschrijf de relevante sociale groepen en de betekenisflexibiliteit ${ }^{100}$ van het artefact door te inventariseren wat de verschillende interpretaties van het artefact door de relevante sociale groepen zijn.

2. Constructie: beschrijf het verdwijnen van de betekenisflexibiliteit als een proces van stabilisatie van de betekenis van het artefact. $^{101}$

3. Reflectie: analyseer het stabilisatieproces en verklaar de stabilisatie met behulp van het begrip technologisch frame.

Die drie stappen van SCOT moeten we niet zien als een blauwdruk voor onderzoek die op basis van data vrijwel automatisch uitgewerkte casestudies produceert. Het is niet meer en niet minder dan een heuristiek voor interpretatief technologieonderzoek.

\subsubsection{RELEVANTE SOCIALE GROEPEN EN BETEKENIS- FLEXIBILITEIT}

In de eerste stap staat de deconstructie centraal door te analyseren welke relevante sociale groepen met hun specifieke interpretatie van de technologie een rol spelen. Uitgangspunt is dat in principe elke sociale groep met een eigen interpretatie van het artefact relevant is omdat ze door haar interpretatie mede vormgeeft aan de ontwikkeling. Rond de ontwikkeling van een medisch artefact zouden artsen een technologie bijvoorbeeld primair kunnen zien als een manier om de kwaliteit van een medische ingreep te verbeteren, terwijl zorgverzekeraars het artefact zien als een mogelijkheid om de efficiëntie van de zorg te vergroten en patiënten als een manier om hun oude leven weer op te pakken. Belangrijk is dat met de betekenisflexibiliteit de eenduidigheid van het artefact verdwijnt en de diversiteit aan betekenissen zichtbaar wordt. Ook al gebruiken verschillende relevante sociale groepen voor dat verschillend gepercipieerde artefact hetzelfde begrip of dezelfde naam, toch kent het een heterogene verschijning. 
In de eerste stap wordt het artefact door de ogen van de relevante sociale groepen wordt beschreven. De onderzoeker moet bepalen worden welke sociale groepen relevant zijn voor de beschrijving van de ontwikkeling van de technologie. Dat betekent echter niet dat al deze interpretaties in de praktijk ook opgenomen moeten worden in de beschrijving. Sommige interpretaties maken de beschrijving nodeloos ingewikkeld doordat ze weinig relevante details toevoegen.

\subsubsection{STABILISATIE}

In de tweede stap wordt bekeken hoe bepaalde interpretaties de overhand krijgen en betekenissen samensmelten. Hoe krijgt het stabilisatieproces vorm en leidt het tot een relatief onomkeerbare en definitieve stabilisatie van de betekenis van het artefact? Als er een gedeeld en eenduidig beeld van het artefact ontstaat tussen de relevante sociale groepen, verdwijnt de betekenisflexibiliteit. Hoe komen we van betekenisflexibiliteit tot een werkende uitgekristalliseerde technologie waarin overeenstemming is over wat ze doet, hoe ze werkt en waar ze geschikt voor is? Bijker introduceert het concept 'stabilisatie' om het uitkristalliseren van een technologie te begrijpen. ${ }^{102} \mathrm{Bij}$ betekenisflexibiliteit gaat het vooral om deconstructie, bij stabilisatie om constructie. Bij stabilisatie staat de ontwikkeling en het uitkristalliseren van de betekenis van het artefact binnen de relevante sociale groepen centraal. Het is een semiotisch concept. In het stabilisatieproces worden de claims rond een artefact steeds groter en minder voorwaardelijk. Er ontstaat daarbij ook consensus tussen de relevante sociale groepen over de dominante betekenis van de technologie. De geschiedenis wordt herschreven en krijgt een definitief karakter, hoewel het in principe altijd mogelijk is de gesloten controverse te heropenen.

\subsubsection{TECHNOLOGISCH FRAME}

De verklaring voor dat proces en eindpunt wordt vervolgens in de derde stap ontwikkeld. Het begrip technologisch frame speelt daarbij een centrale rol. Een technologisch frame bevat alle onderdelen die voor een relevante sociale groep een rol spelen in het ontwikkelen van een interpretatie en vormen van een mening over een artefact. Te denken valt aan de doelen van de relevante sociale groep, de kernproblemen waar ze mee worstelt, gehanteerde theorieën, geaccepteerde tests en ontwerp- 
methode. Daarin heeft ze veel gemeen met Kuhns idee van paradigma's. Ook een paradigma bevat symbolische betekenissen, metafysische vooronderstellingen en waarden, maar is vooral cognitief van aard. Kuhns paradigma was dan ook primair ontwikkeld voor de bestudering van groepen wetenschappers. ${ }^{103}$ Het technologisch frame is bruikbaar voor elke relevante sociale groep. Te denken valt aan groepen van niet-technologen zoals gebruikers, patiënten, zorgverleners, journalisten, politici, bestuurders en beleidsmakers. Een technologisch frame beschrijft kijk- en denk- en doe-wijzen van een relevante sociale groep. Ze structureert de interacties tussen de relevante sociale groepen en het artefact. Ze kadert de doelen, problemen en ideeën en de strategieën en middelen die nodig zijn voor actie. Daarmee legt ze de basis voor de analyse van socio-technische verandering en is ze een sleutelbegrip voor het constructivistisch technologieonderzoek. Een technologisch frame faciliteert en beperkt de actoren. Een technologisch frame wordt echter niet gedragen door individuen of instituties. Een technologisch frame zit niet in de actoren, noch zweeft ze boven de actoren, ze ontstaat en bestaat tussen de actoren. ${ }^{104}$

Een technologisch frame ontstaat deels met de ontwikkeling van het artefact. Belangrijke delen van het technologisch frame hebben de relevante sociale groepen echter al rond eerdere andere artefacten en activiteiten ontwikkeld. Denkend aan de zorg hebben artsen, patiënten en zorgverzekeraars ieder hun eigen eerdere ervaringen met innovatie, zorg en technologie waarop ze voortbouwen. De bestaande praktijk en het bijbehorend technologische frame sorteert zodoende voor op de nieuwe praktijk, overigens zonder dat ze deze vastlegt. Personen maken in de regel onderdeel uit van meerdere sociale groepen en dus van meerdere technologische frames. Dit biedt mogelijkheden om ideeën uit te wisselen of alternatieven in te brengen.

SCOT biedt met haar denken in termen van relevante sociale groepen, betekenisflexibiliteit en technologische frames een kader om technologieontwikkeling empirisch te onderzoeken. Winner heeft als kritiek op deze op empirie gerichte constructivistische benadering, dat ze weinig oog heeft voor dieperliggende sociale processen en ordes, zoals bijvoorbeeld het Marxistische idee van strijd tussen sociale klasse of Dooyeweerdiaanse grondmotieven. Daarnaast merkt Winner op dat het constructivisme geen beoordelingskaders meebrengt voor de onderzochte ontwikkeling. ${ }^{105}$ Winner heeft gelijk dat SCOT a priori geen ordes of kaders introduceert, 
tegelijkertijd is het binnen SCOT goed mogelijk om in de analyse van het empirisch materiaal orde te ontdekken en concepten te introduceren om deze te beschrijven. Als reactie op Winner zouden we kunnen stellen dat SCOT met haar eigen bescheiden begrippenkader een grote ruimte biedt om aanvullende concepten en kaders te introduceren, zolang deze het empirisch materiaal recht doen. Daarnaast biedt SCOT juist de gelegenheid om de beoordelingskaders die in de onderzochte praktijk gehanteerd worden, recht te doen. Begrippen als betekenisflexibiliteit en technologisch frame geven daarvoor ruimte. Binnen het technologische frame kunnen bijvoorbeeld religieuze zaken als geloof, hoop en rituelen relevant zijn en een analytische meerwaarde hebben. SCOT schept aldus ruimte voor het analyseren van de verwevenheid van religie met technologie.

\title{
2.5.5 PROMISING TECHNOLOGY
}

De technologieonderzoeker Harro van Lente geeft met zijn idee van promising technology een handvat om de beloften en verwachtingen van technologie een plek te geven in de analyse van socio-technische ontwikkeling. ${ }^{106}$ Zonder zelf de woorden geloof of religie te gebruiken schept hij ruimte om aandacht te besteden aan geloof in technologie. Beloften en verwachtingen appelleren aan de cognitieve en narratieve geloofskant van religie.

Met beloften en verwachtingen worden verbindingen gelegd tussen heden en toekomst. Volgens Van Lente hebben beloften en verwachtingen echter niet alleen een temporeel verbindende kracht, Ze leggen ook verbindingen tussen actoren, tussen technische en maatschappelijke zaken, tussen de binnen- en de buitenkant van een project. Beloften en verwachtingen leggen de basis voor socio-technische verbinding en verandering, ze zijn een missing link in het technologieonderzoek.

\begin{abstract}
'Expectations are foundational in the coordination of different actor communities and groups (horizontal co-ordination) and also mediate between different scales or levels of organization (micro, meso, and macro-vertical co-ordination). They also change over time in response and adaptation to new conditions or emergent problems (temporal coordination). Likewise, expectations link technical and social issues, because expectations and visions refer to images of the future, where technical and social aspects are tightly intertwined. Finally, expectations constitute "the missing link" between the inner and outer worlds of techno-scientific knowledge communities and fields.' ${ }^{107}$
\end{abstract}


Van Lente c.s. verklaren de groeiende rol van verwachtingen en beloften in de ontwikkeling van technologie door de strategic turn in science and technology. Technologie en wetenschap worden in de samenleving steeds strategischer ingezet, omdat

'Technology development and scientific knowledge are considered of central importance for societal development, not least through economic growth and international competitiveness. Moreover, ... knowledge has become a central driving element of socio-economic and advanced industrial change and thus a key site of strategic focus.' ${ }^{108}$

De crux in bovenstaand citaat zit hem in het woord considered. Wetenschap en technologie worden van centraal belang beschouwd voor de samenleving en economie. Achter de beloften en verwachtingen gaat een maatschappij- en wereldbeschouwing schuil, waarin het geloof in technologie (en wetenschap) als motor voor vooruitgang een centrale rol speelt. In die zin is het concept promising technology zelf een typisch product van een technologische cultuur.

Van Lente gebruikt afwisselend de termen promising technology, visions en expectations. ${ }^{109}$ Die worden allen primair functioneel begrepen. Aangegeven wordt waarom beloften, visies en verwachtingen van belang zijn in innovatieprocessen. Beschreven wordt wat expectations doen en niet zozeer hoe ze zelf ontstaan en waar ze uit bestaan. De opening die Van Lente met het idee promising technology creëert voor religie in socio-technische dynamiek wordt door hem zelf niet benoemd of uitgewerkt.

Het constructivistische technologieonderzoek geeft op verschillende manieren aanleiding en ruimte om de verwevenheden tussen technologie en religie te onderzoeken. Die ruimte blijkt echter nog niet of nauwelijks benut, reden temeer om met dit onderzoek daaraan invulling te geven. 


\subsection{HET SACRALE - EEN \\ CONSTRUCTIVISTISCH PERSPECTIEF OP RELIGIE EN SAMENLEVING}

Om een studie naar de co-constructie van technologie en religie te kunnen uitvoeren is het van belang om naast oog voor technologie ook oog voor religie te krijgen. Naast een theorie en benadering voor technologieonderzoek is een complementaire theorie en benadering voor religie onderzoek nodig. De benadering van religie die de socioloog Émile Durkheim lang voor de SCOT-benadering ontwikkelde, biedt hiervoor een goed bruikbaar vertrekpunt. Anders dan de Christelijke wijsgeren ziet Durkheim religie niet noodzakelijk gegrondvest in een metafysisch fenomeen dat de mens oproept tot een heilige levenswandel. Durkheim ziet religie als een symbolische representatie van de samenleving. Naast deze duiding van religie, geeft Durkheim een bruikbaar conceptueel kader voor onderzoek naar religie waaruit we een onderzoeksopzet kunnen destilleren die complementair is aan de constructivistische aanpak van SCOT.

\subsubsection{HET FUNDAMENTELE ONDERSCHEID SACRAAL - PROFAAN}

Volgens de socioloog Durkheim is het meest fundamentele onderscheid dat mensen maken het onderscheid tussen het sacrale en het profane. In dat onderscheid ligt voor hem de kern van religie. Durkheim beschrijft religie dan ook niet in termen van goden of andere bovennatuurlijke entiteiten. Het onderscheid dat mensen maken tussen het sacrale en profane, tussen het heilige en het alledaagse, is in elke religie terug te vinden en voor Durkheim absoluut en allesbepalend voor die religie. ${ }^{110}$ Daarbij beschouwt Durkheim het sacrale niet als een intrinsiek gegeven van de mensen, dingen of verhalen. Het is een door mensen toegeschreven kwaliteit die voortkomt uit wat in een gemeenschap apart gezet wordt van het alledaagse, het nuttige, het wereldse ofwel het profane. Het sacrale is daarmee van een andere orde en heeft, om met de cabaretier Herman Finkers te spreken, 'geen nut maar wel zin. ${ }^{111}$ Het sacrale roept eerbied, verwondering en verplichting op, maar het sacrale is tegelijkertijd ook het product van diezelfde eerbied, verwondering en verplichting.

In de interactie van geloofsovertuigingen, rituele activiteiten en de morele gemeenschap van de kerk wordt het sacrale onderscheiden en 
apart gezet van het alledaagse leven. In Durkheims beschrijving van religie vinden we drie elementen: geloof, rituelen en gemeenschap. Deze drie vormen het sacrale en zijn het resultaat van het sacrale. Durkheim formuleert het als volgt:

'Religion is a unified system of beliefs and practices relative to sacred things, that is to say, things set apart and surrounded by prohibitions - beliefs and practices that unite its adherents in a single moral community called a church ${ }^{112}$

Het sacrale en profane vormen elk een eigen wereld, die fundamenteel van elkaar verschillen. In zijn ultieme vorm kan een mens alleen helemaal bij de ene sfeer horen als hij de andere helemaal achter zich gelaten heeft. Er is een fundamentele metamorfose nodig. Het hemelse paradijs is pas bereikbaar na het sterven, het nirwana bereikt men door volledige verlichting en onthechting: tot die tijd is het sacrale slechts bij benadering te bereiken. Hierin ligt de basis voor ascese, monastieke tradities en het streven naar verlichting in boeddhistische zin. Het wordt als promiscue ervaren om de sferen met elkaar te vermengen. Daarom zijn er geboden en rituelen om de relatie te leggen. Initiatierituelen bijvoorbeeld begeleiden de overgang naar een andere fase of sfeer.

Het sacrale is in zijn meest pure en ideale vorm weliswaar eindeloos verwijderd van het profane, tegelijkertijd staan ze ook dicht bij elkaar. Het sacrale is volgens Durkheim uiterst besmettelijk waardoor alles in de profane wereld in meer of mindere mate een sacraal karakter kan krijgen. ${ }^{113}$ Zo zijn er heilige boeken, amuletten, totempalen; krijgen priesters, heiligen, goeroes een gewijde rol toebedeeld in rituelen; en zijn er teksten en rituelen die alleen door gewijde personen mogen worden uitgesproken of uitgevoerd. In de dagelijkse praktijk kunnen dergelijke gesacraliseerde zaken een rol krijgen. Dat gaat echter niet zomaar, dergelijke rollen of gebruikswijzen zijn sterk gereguleerd en geritualiseerd. Het blijft dan ook een precaire aangelegenheid om het sacrale met het profane in contact te brengen. Sacrale zaken worden omgeven en afgezonderd van het profane door voorschriften en verboden, al dan niet in combinatie met materiële af- of bescherming. Rituelen en regels geven aan hoe het sacrale benaderd behoort te worden en hoe men zich hoort te gedragen in relatie tot het sacrale. Het sacrale en profane zijn in de praktijk vaak op subtiele wijze dubbelzinnig en contextueel bepaald. Het vraagt om wat men in het technologieonderzoek tacit knowledge noemt om ze te kunnen invoelen, begrijpen 
en te praktiseren. Protestanten zullen bijvoorbeeld op rituele momenten uiterst zorgvuldig met de bijbel omgaan en een oude statenbijbel is voor hen een bezit met een onuitgesproken maar desondanks op zijn minst heilig laagje. De Statenvertaling staat voor de traditie en de waarde van het Woord, ze representeert het Sola Scriptura. Tegelijkertijd kunnen veel protestanten een versleten huisbijbel zonder problemen bij het oud papier gooien. Het gaat immers om het Woord en niet om het papier.

Met zijn focus op het sacrale als de kern van religie ontwikkelt Durkheim een benadering van religie waarin a priori geen inhoudelijke of transcendente vooronderstellingen worden gedaan. Vanuit dit perspectief valt religie niet samen met godsdienst of levensbeschouwing. Religie wordt immers bepaald door wat mensen als sacraal ervaren en apart zetten en dat hoeven niet noodzakelijk goden te zijn. Voor Durkheim is religie daarnaast ook meer dan een beschouwing van het leven. Religie is beter te begrijpen als een manier van leven, een levensvorm waaraan mensen uitdrukking geven door geloof, rituelen en gemeenschappen. Om die levensvorm te onderzoeken legt Durkheim in zijn onderzoek de nadruk op de religieuze praktijk en komt het mensenwerk van religie centraal te staan. In zijn benadering van religie construeren mensen sacrale vormen met behulp van drie elementen: geloof, rituelen en morele gemeenschap. Een gemeenschap geeft met geloof en rituelen vorm aan religie. Zij vormen het religieus frame voor de gemeenschap.

\subsubsection{GELOOF}

Geloof betreft opvattingen, ideeën en representaties en rituelen zijn uitgekristalliseerde handelingspatronen. Ze verhouden zich tot elkaar als denken en doen. ${ }^{114}$ Geloof is de verhalende en cognitieve kant van religie. Ze biedt orde en inzichten en veronderstelt een classificatie van de dingen. Bijvoorbeeld over hoe de dingen zijn en hoe ze zouden moeten zijn. De waarneembare stand van zaken in de profane wereld en de idealen uit de sacrale wereld worden onderscheiden. Op basis van dat onderscheid wordt het mogelijk geloofsverhalen, mythen en wetten te ontwikkelen waarin representaties van de aard van het sacrale en het ontstaan van de wereld en het leven kunnen worden beschreven. De inhoud van het sacrale wordt zo onder woorden gebracht en minstens zo belangrijk: de relatie van het sacrale met het profane kan worden verwoord. Geloofsverhalen zijn inhoudelijk zeer divers en tegelijkertijd sterk verbonden, ze verhalen over idealen, hoop, verwachtingen, over mens en wereldbeelden, orde en kosmologie, over wetten, gebruiken en dogmatiek, over mensen en goden, over ethiek en moraliteit. Om dat alles uitdrukking te geven 
worden zeer verschillende vormen en technieken worden gebruikt. ${ }^{115}$ Dat is bijvoorbeeld zichtbaar in de Bijbel. ${ }^{116} \mathrm{De}$ Bijbel is samengesteld uit een verzameling boeken, met daarin onder meer wetboeken, spreuken, geschiedenisboeken, profetieën, gedichten en liederen. ${ }^{117}$

Geloof bepaalt mede hoe gelovigen de wereld, het leven en zichzelf kennen. Het vormt de perceptie van mensen en geeft een basis voor hun handelen. Vaak kent geloof een formeel kader van overtuigingen en inzichten en daarnaast meer alledaagse geloofsvoorstellingen. Religies kunnen dan ook niet gereduceerd worden tot één uniek en eenduidig idee of principe. Ze bestaan uit homogene en tevens diverse families van heilige geloofsverhalen, teksten en rituelen waar de gelovigen zich rond verzamelen en toe verhouden. ${ }^{118}$ In een seculiere cultuur is geloof in de regel een impliciet gegeven. Belangrijke waarden en idealen zoals individualiteit, vrijheid en gezondheid worden niet religieus geduid maar als vanzelfsprekend beschouwd los van geloofsovertuigingen. Inzicht in het geloof in een technologische cultuur vraagt om explicitering hiervan door analyse en onderzoek.

\subsubsection{RITUELEN}

Een tweede constituerend fenomeen voor religie is het ritueel: de uitvoering van religieuze activiteiten waarmee vorm wordt gegeven aan religie in de praktijk. Rituelen bieden een handelingsperspectief ten overstaan van het sacrale. Volgens Durkheim zorgen rituelen voor:

'the rules of conduct which prescribe how a man should comfort himself in the presence of these sacred objects'.119

Zo ontstaan relatief vastliggende activiteiten die samenhangen met het geloof. Rituelen onderscheiden zich van andere menselijke activiteiten door hun focus op het sacrale, ze maken het sacrale op deze manier praktisch benaderbaar. Een ritueel kan daarom alleen begrepen worden in relatie tot het sacrale en de ordening daarvan zoals die in het geloof uitgedrukt wordt. ${ }^{120}$ Ze staan dan ook niet op zichzelf maar zijn onderdeel van een groter geheel aan overtuigingen en sociale verbanden georgani-

115 Media-technologieën zoals schrift, boekdrukkunst, televisie en digitalisering geven mede vorm aan religie. Vries en Weber, Religion and media.

116 De Joodse Thora en de gevarieerde Hindoeïstische geschriften zijn andere voorbeelden.

117 Het woord bijbel is afgeleid van het Griekse biblia, wat boeken of bibliotheek betekent.

118 McGuire, Religion, the social context, 15-17.

119 Durkheim, The elementary forms of religious life, 40.

120 Durkheim, 36. 
seerd rond het sacrale. Karakteristiek voor rituelen is dat het al dan niet periodiek terugkerende activiteiten zijn, die heden en verleden verbinden en onderdeel zijn van een groter geheel aan riten, ceremonies en festiviteiten. ${ }^{121}$ Met rituelen worden de groep en het geloof van tijd tot tijd herbevestigd. ${ }^{122}$ Door te zorgen voor wederzijdse emotionele afstemming tussen mensen, bevestigen en versterken rituelen sociale verbanden rond het sacrale en daarmee de verbondenheid tussen generaties.

Rituelen worden opgebouwd uit een samenspel tussen mensen, artefacten, verhalen, tijd en ruimte. Hun sacrale lading wordt gevormd door en bevestigd in het ritueel. Kerkdiensten, het vrijdaggebed en synagogebezoek op sabbat illustreren dat. Ze kennen een vast plek in de week en een temporele opbouw. Handelingen moeten in een vaststaande volgorde gedaan worden om effect te sorteren. Ze vinden bij voorkeur plaats op gewijde grond en in de daarvoor zorgvuldig vormgegeven omgeving van moskee, synagoge of kerk. Priesters, predikanten, imams en rabbi's zijn gewijde voorgangers die een centrale rol spelen, zij kunnen echter niet zonder de gemeente, de groep gelovigen die in die situatie een eigen heilige eenheid vormt. Deze onderscheidt zich in het dagelijks leven door bijvoorbeeld (zondagse) kleding, keppel of door rituele wassing. In de religies van het woord spelen verhalen en heilige boeken een zichtbaar centrale rol. Bijbel, Thora en Koran worden actief gebruikt en zijn essentiële artefacten in het ritueel. Die rol gaat verder dan het lezen van het woord. De behandeling van het boek of de boekrol is zorgvuldig en expliciet omlijst met rituele handelingen. Hoewel veel rituelen een ingeslepen karakter hebben zijn rituelen tegelijkertijd steeds in ontwikkeling in samenhang met de ontwikkeling van de gemeenschap en het geloof. Als sociale verbanden en geloof onder druk komen te staan, ontstaat ook weerstand tegen de verweven rituelen. In het extreme geval wordt een ritueel op een gegeven moment als leeg en formalistisch ervaren. ${ }^{123}$

Durkheim maakt onderscheid tussen positieve en negatieve rituelen. Negatieve rituelen begrenzen, ze zorgen dat er geen onwenselijk contact of uitwisseling is tussen het sacrale en het profane. ${ }^{124}$ Negatieve rituelen betreffen de dingen die men niet moet doen, de verboden, taboes en onthoudingsvoorschriften. ${ }^{125}$ Voorbeelden zijn de zondagsrust op basis

121 Alexander, Giesen, en Mast, 'Performing the sacred: a Durkheimian perspective on the performative turn in the social sciences'

122 Durkheim, The elementary forms of religious life, 287

123 Collins, Interaction ritual chains.

124 Durkheim, The elementary forms of religious life, 221-22.

125 Lynch, The sacred in the modern world, 24. 
waarvan men in principe op zondag niet werkt en anderen niet laat werken of het verbod op het eten van varkensvlees zoals we dat vinden in het Jodendom en de Islam. Dergelijke verboden lijken op het eerste gezicht een minder directe verbinding met het sacrale te hebben. De spijswetten worden daarom soms verklaard als voortkomend uit hygiënische in plaats van religieuze motieven. Alternatieve verklaringen reduceren ze vaak tot primitieve aberraties van het geloof. Mary Douglas laat echter zien dat spijswetten erop ingericht zijn om het sacrale te beschermen tegen verontreiniging met het profane. Ze maakt duidelijk dat bijvoorbeeld varkens onrein zijn omdat ze buiten de religieuze scheppingsorde vallen. ${ }^{126}$

De negatieve rituelen maken de positieve rituelen mogelijk. Door negatieve rituelen ontstaat de ruimte om het sacrale te benaderen. Pas na een bepaalde tijd van onthouding is men bijvoorbeeld rein genoeg om het sacrale te naderen. Positieve rituelen zijn vervolgens bedoeld om in een speciale staat te komen teneinde het sacrale te ervaren. Voor Durkheim is dat een staat van collectieve opwinding. Die extase is echter niet noodzakelijk. Mary Douglas laat zien dat de katholieke rituelen die zij van huis uit meemaakte, juist 'dignified, but tedious slow and elaborate' waren. Er is geen sprake van spontaniteit of ander extatisch gedrag. Iedereen is juist bezorgd over de zorgvuldige timing en plaatsing van de mensen, de woorden, en de dingen. ${ }^{127}$ Dat neemt niet weg dat ook deze rituelen groepen mensen helpen om bepaalde geestestoestanden op te roepen en collectief te beleven. ${ }^{128}$

Positieve rituelen kennen verschillen in gewicht en frequentie. Hoogtijdagen als Kerst en Loofhuttenfeest of het bezoek aan Mekka kennen een andere zeggingskracht en bieden een andere ervaring dan het dagelijkse christelijk tafelgebed, de Islamitische salat (de vijf dagelijkse rituele gebeden), en de Joodse kasjroet (de spijswetten). Aan personen gerelateerde rituelen, zoals besnijdenis, huwelijk en crematie, hebben door hun aard en intimiteit een grote zeggingskracht. Ze spelen een krachtige bevestigende rol bij initiaties, transformaties en unieke relaties. In het christendom zijn dat bijvoorbeeld: de doop, de zegening van het huwelijk en overlijdensrituelen. Als een mens overvallen of geconfronteerd wordt met de grenzen en grootsheid van het leven, dan geven rituelen een praktisch houvast. Als je niet meer weet wat te doen, dan helpen rituelen om te weten wat je moet doen. Rituelen zorgen voor betekenis, stabiliteit en verbondenheid. 
Het concept rituelen wordt nauwelijks toegepast op de technologische cultuur, toch zijn er ook daar genoeg rituelen te herkennen. Net als geloof zijn rituelen in een technologische cultuur impliciet en worden niet als religieus geduid. In de leefstijlzorg ${ }^{129}$ ontstaan nieuwe rituelen voor het goede gezonde leven. Bij het gebruik van alcohol en sigaretten gaat het om negatieve rituelen die ontmoedigingen en verbieden. Positieve rituelen draaien om lichamelijke en geestelijke activiteiten als sport, eten en mindfulness. Sport is daarbij, interessant genoeg, geen verlengde van spel of competitie, maar een functionele activiteit voor het bereiken van het hogere doel: gezondheid. Dooyeweerd zou zeggen: de kwalificerende functie van sport verschuift van het formatieve (spelende, vormende) naar het morele (zorg). Een vergelijkbare verschuiving in kwalificerende functie zien we bij mindfulness en yoga van het pistische (religieuze) naar het morele. Waarbij de morele zelfzorg interessant genoeg weer een hoge pistische status krijgt en minder functioneel wordt. De opkomst van fitnesscentra en -apparatuur is daarbij te zien als een materialisatie van een op gezondheid gerichte technologische leefstijl- en lichaamscultuur.

\subsubsection{GEMEENSCHAP}

Religie wordt gedragen door wat Durkheim noemt een morele gemeenschap. Mensen geven met elkaar vorm aan geloof en rituelen; ze zijn een essentieel onderdeel van religie. Religie is geen zaak van het individu alleen, maar een sociale activiteit die haar basis vindt in een morele gemeenschap. Zonder gemeenschap geen religie.

Voor Durkheim is de morele gemeenschap en niet het individu of de voorganger het dragend element voor een religie. In een morele gemeenschap hebben de leden gedeelde ideeën over het heilige en vertalen die in rituelen. Een dergelijke morele gemeenschap kan een verband rond een nationale civil religion ${ }^{130}$ zijn of één van de grensoverschrijdende wereldreligies, maar ook een al dan niet zelfstandige denominatie of lokale gemeente. Soms is een kerk een tot in detail georganiseerd instituut en wordt ze geleid door voorgangers en priesters met een bijzondere status. Andere morele gemeenschappen zijn klein en informeel van aard en hebben het karakter van een kleine cult ${ }^{131}$ zoals een huisgemeente.

\footnotetext{
129 Lemmers en Greeff, Gezondheidsbevordering en leefstijl: een praktische inleiding. Stichting Je leefstijl als medicijn, 'Stichting Je leefstijl als medicijn'.
}

130 Bellah en Hammond, Varieties of civil religion.

131 Durkheim, The elementary forms of religious life, 42-44.Verwijzing naar TEFoRL 
In de morele gemeenschap leren de individuele leden over de aard van het sacrale en hoe ze daarmee een relatie kunnen aangaan. Ze leren de relevante categorieën en hun rol in de gemeenschap en de daarbij horende rechten en plichten. Ze ervaren de vormen en rituelen en herbeleven de gemeenschappelijke geschiedenis, mythen en verhalen en worden zo onderdeel van het gemeenschappelijk geheugen en de gemeenschap. In de technologische cultuur zien we dergelijke gemeenschappen bijvoorbeeld ontstaan rondom ziekte en gezondheid in de vorm van stichtingen $^{132}$, fondsen ${ }^{133}$ en verenigingen ${ }^{134}$ waarin mensen zich organiseren, idealen nastreven en hun vertrouwen stellen in bijvoorbeeld wetenschap en technologie.

\subsubsection{DE CONSTRUCTIE VAN HET SACRALE IN MODERNE SAMENLEVINGEN}

Met het centraal stellen van het onderscheid tussen het sacrale en profane in zijn idee van religie is in Durkheims benadering niet noodzakelijk een rol weggelegd voor het transcendente. Daarin verschilt zijn concept van religie bijvoorbeeld van dat van Dooyeweerd. Met het pistische aspect veronderstelt Dooyeweerd op een ontologisch niveau het transcendente: bij Dooyeweerd kan religie niet bestaan zonder het goddelijke. Desondanks kunnen de benaderingen van Durkheim en Dooyeweerd elkaar aanvullen. Voor Dooyeweerd betekent het gegeven dat religie van boven komt, niet dat de sociale praktijk er beneden niet toe doet. Volgens Dooyeweerd ontsluiten mensen de ervaringswerkelijkheid in het licht van wat daaraan transcendeert. Er vindt dan van onderaf een sociale constructie van het transcendente plaats, zonder dat dat betekent dat het transcendente gereduceerd wordt tot die constructie. Vanuit een methodologisch relativistische benadering, waarbij er geen uitspraken worden gedaan over het bestaan of de aard van het transcendente, kunnen Dooyeweerd en Durkheim elkaar versterken.

Durkheim benadert religie als een sociaal fenomeen, zoals Bijker dat met technologie doet. Met zijn sociologische analyse van religie ontwikkelt Durkheim tegelijkertijd ook de basis voor een eerste kennissociologische theorie. In die theorie is kennis voor Durkheim niet slechts een product van menselijke ervaring, noch een toepassing van vooraf gegeven mentale categorieën op de wereld. Categorieën zijn sociale constructies en collectieve representaties. ${ }^{135}$ Of zoals Durkheim het stelt: 
'The categories of human thought are never fixed in a definitive form. They are made, unmade and remade incessantly; they vary according to time and place. ${ }^{{ }^{136}}$

Durkheim laat zien dat cognitieve en morele categorieën zijn ingebed in het sociale leven. Daarmee is Durkheim te beschouwen als één van de wegbereiders voor het constructivisme. Het menselijk denken en waarnemen vertrekt voor Durkheim met het eerste en meest basale onderscheid tussen de categorieën van het sacrale en het profane. Op basis daarvan wordt het classificatiesysteem verfijnt en uitgewerkt. Het classificatiesysteem ordent bijvoorbeeld de omgang met tijd en ruimte. Het besef van tijd ontstaat door de periodisering tussen religieuze feesten en de ruimte wordt primair geordend doordat het universum sacrale en profane plaatsen kent. Religie is de basis voor de kosmologie van een groep of samenleving en daarmee een fundament voor de opbouw en dynamiek van die samenleving. ${ }^{137}$

Durkheim maakt in zijn werk een onderscheid tussen de mechanische solidariteit van vroegere samenlevingen en de organische solidariteit van de moderne samenleving. ${ }^{138}$ De antropologe Mary Douglas, wier werk voortbouwt op dat van Durkheim, doorbreekt dit onderscheid tussen 'primitieve' en 'moderne' samenlevingen. ${ }^{139}$ Op basis van het werk van Durkheim ontwikkelt zij juist een symmetrische benadering en een antropologische blik op de moderne samenleving. In haar baanbrekende boek Purity and Danger, onderzoekt ze de kosmologie en orde van de moderne samenleving. Ze stelt daarbij dat:

'we should try to compare peoples' views abouts man's destiny and place in the universe. In the second place we shall not expect to understand other people's ideas of contagion, sacred and secular, until we have confronted our own. ${ }^{140}$

Met deze visie maakt Douglas het onderzoek naar de moderne technologische cultuur aan de hand van Durkheims benadering zowel mogelijk als urgent. Die onderzoekspositionering is een belangrijk vertrekpunt

136 Durkheim, The elementary forms of religious life, 16.

137 Cladis, 'Introduction'.

138 Durkheim, The division of labor in society.

139 Hendel, 'Mary Douglas and anthropological modernism'.

140 Douglas, Purity and danger: an analysis of concepts of pollution and taboo., 35. 
geworden voor het wetenschaps- en technologieondezoek. ${ }^{141}$ Verder denkend in de lijn die Douglas heeft ingezet, heeft bijvoorbeeld de Keniaanse antropoloog Mwenda Ntarangwi een reversed gaze ontwikkeld waarbij westerse culturen door niet-westerse antropologen worden onderzocht en symmetrie tussen de benaderingen van culturen en hun onderzoekers verder wordt uitgewerkt. ${ }^{142}$

\subsubsection{SACRALE VORMEN IN DE PRAKTIJK}

Durkheim geeft een helder begrippenkader voor het onderzoeken van religie. Religie ontstaat uit een samenspel van geloof, rituelen en gemeenschap rond het sacrale. Durkheim spreekt daarbij over het sacrale in enkelvoud. Moderne samenlevingen kennen echter een pluraliteit aan religieuze vormen, die elkaar overlappen en elkaar beïnvloeden. Bellah laat bijvoorbeeld in zijn studie naar de civil religion van de Verenigde Staten zien dat er pluriformiteit van het sacrale bestaat. ${ }^{143}$ De Amerikaanse civil religion bestaat immers naast de confessionele religies in diezelfde samenleving. Verschillende sacrale vormen kunnen naast elkaar bestaan en met elkaar verweven zijn. ${ }^{144}$ Daarnaast laat Bellah's casus van de civil religion zien dat het sacrale historisch contingent is. Ze is niet alleen een reactie op de religieuze vervolgingen die de founding fathers hadden ondergaan, maar ook een nadrukkelijk wijzen op individuele rechten en vrijheid die terug te voeren zijn op de Reformatie. Het sacrale van de civil religion is ook een typisch product van een specifieke geschiedenis van de nation state. Niet elke natie kent een civil religion. In die zin is ze geen universeel fenomeen maar verbonden aan historische processen, lokale omstandigheden en gebeurtenissen. ${ }^{145}$ In aanvulling daarop laat Jeffrey Alexander zien hoe vormen van onderscheid tussen het sacrale en profane 'shifting cultural constructions' zijn, en daarmee aan verandering onderhevig. ${ }^{146}$ Zelfs breed gedeelde zaken met een 'capacity for universal moral sympathy' zoals mensenrechten, democratie en duurzaamheid zijn geen tijdloze waarheden, maar zijn het resultaat van een specifieke culturele geschiedenis die om onderhoud vragen. ${ }^{147}$ Het werk van Bellah en Alexander laat zien dat het sacrale pluriformiteit kent en geconstrueerd

141 Latour en Woolgar, Laboratory life: the construction of scientific facts; Knorr-Cetina en Harré, Die Fabrikation von Erkenntnis : zur Anthropologie der Naturwissenschaft.

142 Ntarangwi, Reversed gaze: an African ethnography of American anthropology.

143 Bellah, 'Religion and legitimation in the American Republic'.

144 Lynch, The sacred in the modern world, 36.

145 Lynch, 49.

146 Alexander, 'The computer as sacred and profane'.

147 Alexander, The meanings of social life. 
wordt in contingente, historische processen. ${ }^{148}$ Door te spreken van het sacrale ontstaat de suggestie van eenheid en eenduidigheid. Dat doet geen recht aan de variëteit en nuance die onder het sacrale verborgen gaan. Op basis van deze inzichten stelt Gordon Lynch voor om naast het sacrale te spreken van sacrale vormen. ${ }^{149}$ Hij definieert een sacrale vorm als volgt:

'Sacred forms are specific, historically contingent instances of the sacred. Sacred forms are constituted by constellations of particular sacred symbols, thoughts/discourse, emotions and actions which recursively reproduce the sacrality of that sacred form and draw together groups who share these discourses, sentiments and practices. The normative reality constituted by a sacred form simultaneously constructs the evil which might profane it. ${ }^{150}$

Sacrale vormen geven inzicht in hoe het sacrale in een bepaalde situatie tot uiting komt. Het idee van sacrale vorm schept ruimte voor onderzoek naar religieuze diversiteit in een technologische cultuur. Sacrale vormen kunnen naast elkaar bestaan, met elkaar op gespannen voet staan of een meer productieve dialectische relatie hebben. De relaties tussen sacrale vormen worden zichtbaar en besproken in de media, de rechtszaal en politiek. ${ }^{151}$ Een sacrale vorm maakt immers niet zozeer zichtbaar wat er technisch mogelijk is maar ook wat er wenselijk is. Het idee van sacrale vormen maakt het massieve onderscheid tussen het sacrale en profane hanteerbaar en geeft een handvat om de werking van het sacrale in een praktijk, zoals de probe PAZIO, te onderzoeken.

\subsection{ONDERZOEKSVRAGEN}

Het doel van dit onderzoek is om zicht te krijgen op de aanwezigheid en rol van religie in een technologische cultuur. De vraag naar religie in een technologische cultuur is echter geen vanzelfsprekende. Een technologische cultuur laat zich juist graag karakteriseren als seculier en rationeel, voor religie is daarin geen vanzelfsprekende plaats.

\footnotetext{
148 Lynch, The sacred in the modern world, 38-43.

149 Lynch spreekt in het Engels van sacred forms, de meest juiste vertaling naar het Nederlands is 'vormen van het sacrale'. Om dicht bij de oorspronkelijke terminologie te blijven, houd ik het in het vervolg van de tekst bij 'sacrale vormen'.

150 Lynch, The sacred in the modern world, 47.
}

151 Jasanoff en Kim, Dreamscapes of modernity: sociotechnical imaginaries and the fabrication of power, 4. 
Om de rol van religie in een technologische cultuur te onderzoeken nemen we de ontwikkeling van het gezondheidsportaal PAZIO als probe. Gezondheid en technologieontwikkeling zijn belangrijke pijlers in een technologische cultuur. Daarmee kunnen we de rol van religie in de kern van de technologische cultuur onderzoeken.

Met behulp van de in dit hoofdstuk geïntroduceerde theoretische benaderingen kunnen we de doelstelling van dit onderzoek vertalen in een onderzoeksvraag en sub-vragen. De doelstelling is om zicht te krijgen op de rol van religie in een technologische cultuur. Dit laat zich vertalen naar een vraag naar het sacrale in een technologische cultuur. De centrale onderzoeksvraag wordt daarmee:

Hoe wordt in een technologische cultuur vormgegeven aan het sacrale?

Om die vraag te beantwoorden onderzoeken we de techno-religieuze dynamiek in de probe 'de ontwikkeling van PAZIO'. We analyseren de co-constructie van technologie en de sacrale vorm van PAZIO. Voor het empirisch onderzoek is de leidende vraag:

Hoe ontwikkelt de co-constructie van de technologie en de sacrale vorm van PAZIO zich?

SCOT, TIM en Durkheims benadering van religie geven elk een eigen benadering van een praktijk en gebruiken daarbij eigen concepten. Tegelijkertijd gebruiken ze daarbij in de analyse vergelijkbare heuristische middelen: sociale verbanden en hun frames, waarbij frames bestaan uit narratieven en activiteiten. Durkheim onderscheidt ze als geloof en rituelen. In dit onderzoek wordt van de verschillen en overeenkomsten tussen deze benaderingen gebruik gemaakt. Op basis daarvan komen de volgende drie sub-vragen aan de orde:

1. Hoe ontwikkelt zich een sacraal geloof in de ontwikkeling van PAZIO?

2. Hoe ontwikkelen zich sacrale rituelen in de ontwikkeling van PAZIO?

3. Hoe ontwikkelt zich een sacrale gemeenschap in de ontwikkeling van PAZIO?

De komende drie empirisch geïnformeerde hoofdstukken worden georganiseerd aan de hand van deze drie-eenheid van achtereenvolgens geloof, rituelen en gemeenschap. Daarbij worden de gepresenteerde theoretische perspectieven benut. In het afsluitende hoofdstuk met conclusies worden de onderzoeksvragen beantwoord en worden theoretische en methodologische inzichten gepresenteerd. 


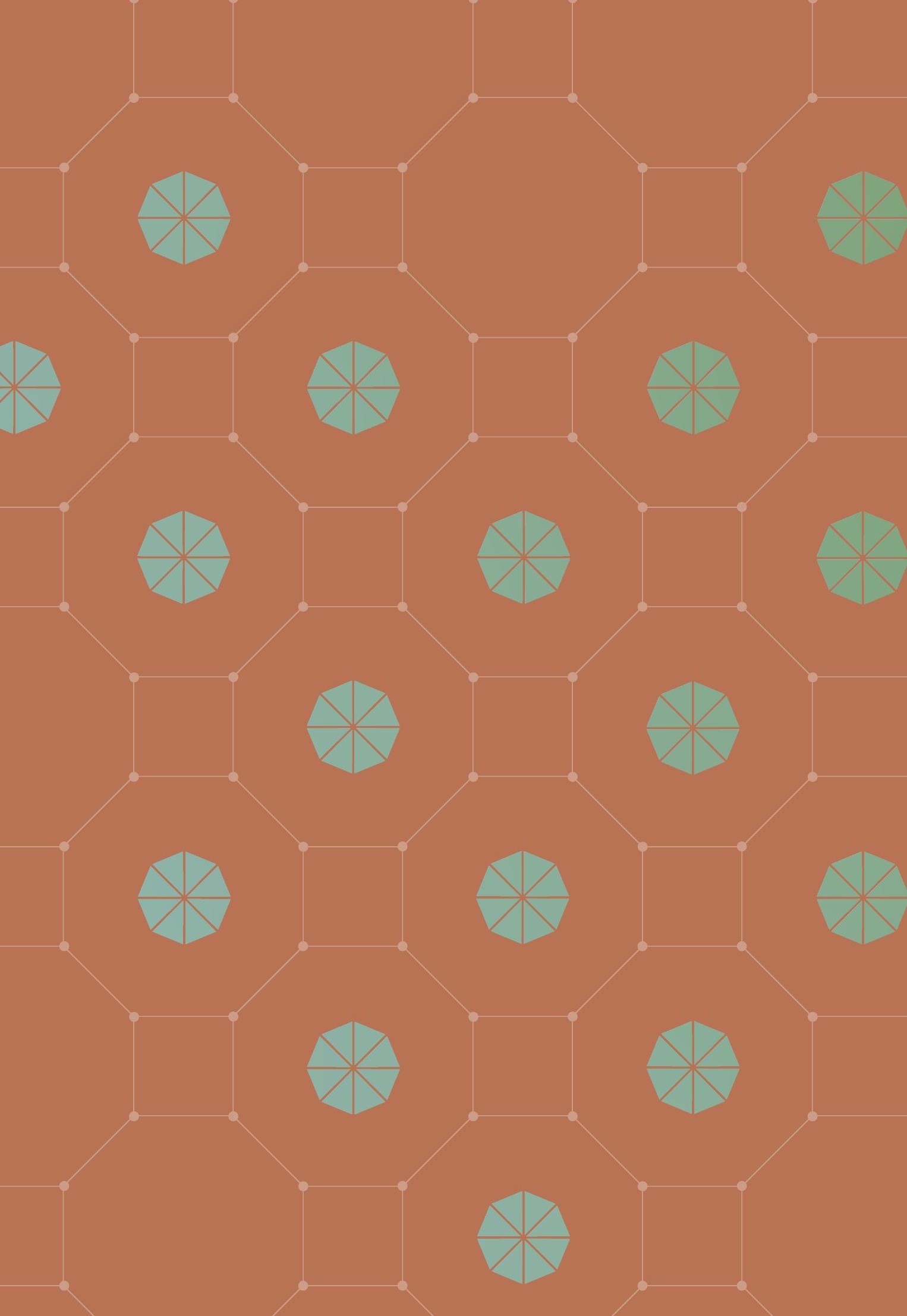




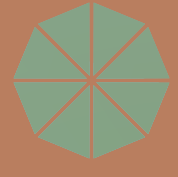




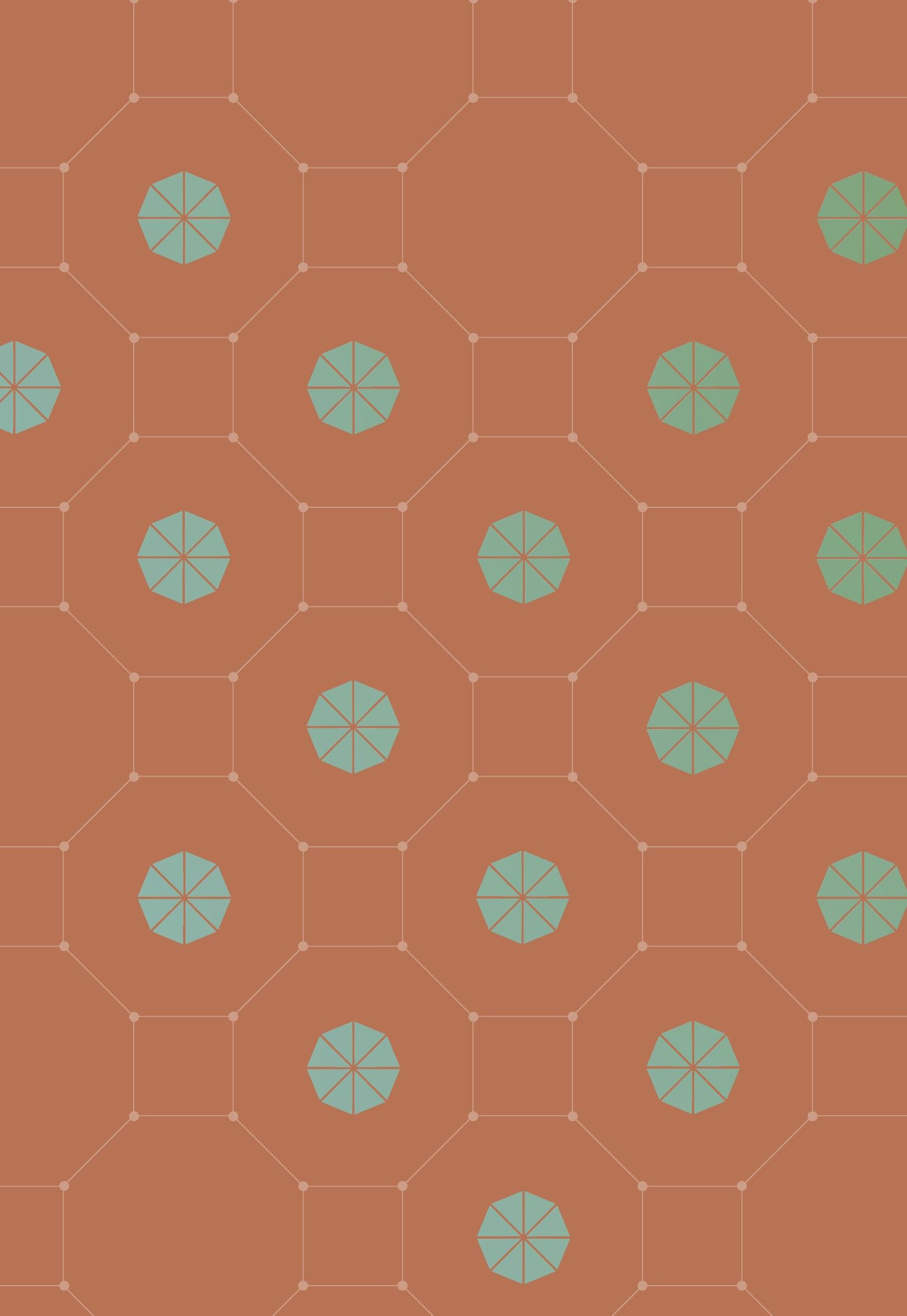




\section{3 de co-constructie VAn GELOOF EN TECHNOLOGIE}

\subsection{INLEIDING}

Durkheim laat zien dat geloof, naast rituelen en de morele gemeenschap, een belangrijk ingrediënt is van religie. In dit hoofdstuk beschrijf ik hoe zich met de ontwikkeling van het gezondheidsportaal PAZIO ook het geloof in PAZIO ontwikkelt. De focus ligt hier op de periode tussen 2006 en 2010 . In die periode ligt de nadruk op de gedachtevorming rond PAZIO en het opzetten van het project.

Ik begin mijn analyse bij het eind van deze periode: de kick-off waar het nieuw te starten project gepresenteerd wordt. Ik kijk naar de bijeenkomst, de bijdrage van de sprekers en naar de daar vertoonde film over PAZIO. Aan de hand daarvan beschrijf ik de aard van het geloof in PAZIO en hoe dat geloof overtuigend wordt geconstrueerd.

Vervolgens beschrijf ik hoe dat geloof door de jaren heen ontstaan is. Op chronologische volgorde analyseer ik verschillende documenten die een centrale rol spelen in de PAZIO-geschiedenis. De focus ligt daarbij op de idealen, vooronderstellingen en beloften die in die documenten naar voren komen. Ik volg hoe deze in de tijd inhoudelijk ontwikkelen en beschrijf de dynamiek achter die ontwikkelingen.

Ik sluit het hoofdstuk af met conclusies over de aard en het constructieproces van het geloof in PAZIO. 


\subsection{DE KICK-OFF}

"Door de toenemende zorgvraag komen er veel nieuwe initiatieven van de grond in de zorgsector. Eén daarvan betreft het gezondheidsportaal PAZIO (Patiëntgeoriënteerde Zorg Informatie Omgeving). Het gezondheidsportaal PAZIO is gestart in de woonwijk Leidsche Rijn van de gemeente Utrecht en biedt een platform waar zorgconsumenten succesvolle E-health toepassingen veilig kunnen gebruiken. Het doel is erop gericht om het PAZIO-portaal landelijk verder uit te rollen.

De provincie Utrecht en de gemeente Utrecht verlenen samen 1 miljoen euro cofinanciering aan de ontwikkeling van PAZIO. Het Ministerie van Economische Zaken heeft daarnaast via de subsidieregeling Pieken in de Delta een subsidie van 1 miljoen euro toegekend. De subsidie zal onder meer gebruikt worden om de benodigde software verder te ontwikkelen, voor de promotie en introductie van het platform bij de gezondheidsinstellingen en voor de ontwikkeling van een innovatief kenniscentrum." ${ }^{152}$

Met deze alinea's opent de persoonlijke uitnodiging voor de kick-off van het project PAZIO. Het is de eerste officiële beschrijving van PAZIO voor een breder publiek. De uitnodiging is ook het eerste officiële stuk is dat ik van PAZIO ontvang. Donderdag 11 februari 2010 om een uur of drie stap ik het Descartes-Centrum van het UMCU binnen en zet mijn eerste stappen in de wereld van PAZIO om mee te werken aan de ontwikkeling van PAZIO en om mijn onderzoek te starten.

De bezoekers van de kick-off van PAZIO zijn allen op persoonlijke titel uitgenodigd. Ze zijn werkzaam in het midden en hoger management van verzekeraars, ziekenhuizen, zorginstellingen, softwarebedrijven, overheden. Daarnaast zijn de leden van het klantenpanel van PAZIO aanwezig. ${ }^{153}$

Bij de koffie tijdens de inloop maak ik kennis met Van Marken, directeur van UMCU Holding. Hij vertelt me dat PAZIO zich straks van een project tot een zelfstandige onderneming moet ontwikkelen. Hij heeft meegedacht over businessmodellen, intellectueel eigendom en de verdeelsleutels voor de aandelen. Vandaar dat hij vanmiddag ook een kijkje komt nemen. ${ }^{154}$ 
Nadat projectleider De Lange de aanwezigen welkom heeft geheten, is het woord aan Kuilboer, de voorzitter van de PAZIO-stuurgroep en directeur Concern Staf UMCU. Hij vertelt dat PAZIO zich richt op de $0^{\mathrm{e}}$ en $1^{\mathrm{e}}$ lijn door middel van zelfmanagement en huisartsenzorg. Hij focust in zijn verhaal op het ontwikkelen van PAZIO. Op enthousiaste wijze introduceert hij zijn vijf voorwaarden voor succesvolle innovatie aan het publiek. Je moet een simpel idee hebben, aansluiten bij een behoefte, enthousiasme zoeken, niet blijven denken maar beginnen met doen én support blijven zoeken en derden laten mee doen. ${ }^{155}$ PAZIO is in het zoeken van support zonder meer succesvol geweest. Op de uitnodiging voor de kick-off bijeenkomst staan alle relevante partijen: 'PAZIO komt tot stand door: Gemeente Utrecht, Imtech, Leidsche Rijn Julius Gezondheidscentra, Mediportaal, Ministerie van Economische Zaken, NPCF, Provincie Utrecht, UMC Utrecht, Universiteit Twente, VitaValley, VitalHealth Software'156 Het is een gevarieerd gezelschap dat vertrouwen heeft in PAZIO en in PAZIO wil investeren. Hoe en waarom ze zich rond PAZIO verzameld hebben wordt niet toegelicht en ook de ontwikkelstatus van PAZIO komt die middag niet aan de orde. Op de uitnodiging staat niet meer over PAZIO dan 'PAZIO Uw gezondheidsportaal'. ${ }^{157}$ Waar is het vertrouwen van deze partijen op gebaseerd? Wat hopen en verwachten ze? Op wie 'Uw' betrekking heeft en wat een gezondheidsportaal is, wordt hier niet toegelicht. Klaarblijkelijk is dat niet nodig om mensen te verleiden om naar de kick-off te komen. De zaal zit vol en deze middag krijgen we een indruk van wat PAZIO beoogt. Speciaal voor deze gelegenheid is een promotiefilm voor PAZIO gemaakt.

De film opent met mevrouw De Wolf en sluit er ook mee af. Mevrouw De Wolf is een dame op leeftijd met verschillende chronische aandoeningen en als patiënt ingeschreven bij het Leidsche Rijn Julius Gezondheidscentrum. Ze woont in Leidsche Rijn en is lid van het klantenpanel van PAZIO. Mevrouw De Wolf vormt de omlijsting van de film, de kern van de film is gevuld met de ambities en verwachtingen die artsen, hoogleraren en bestuurders van PAZIO hebben. Daarbij gaat het om zaken als betrouwbare informatie, eenvoudige communicatie en efficiëntie in de zorgpraktijk en in het zorgonderzoek.

$\mathrm{Na}$ de film spreekt Van Lunteren, de gedeputeerde Mobiliteit, Economie en Financiën van de Provincie Utrecht. Hij vertelt hoe hij in zijn familiebedrijf de kracht van innovatie heeft leren kennen en deze als ondernemer heeft benut. PAZIO is voor Van Lunteren een motor voor 
economische stimulering in de regio. Dat heeft het rijk en de provincie overtuigd om PAZIO te subsidiëren. De Pieken in de Delta-subsidies van provincie en Ministerie EZ zijn niet voor niets economische subsidies gericht op het stimuleren van bedrijvigheid, innovatie en ondernemerschap. ${ }^{158}$

Als De Lange namens PAZIO de link weer heeft gelegd naar de patiënt, mag mevrouw De Wolf in haar rol van patiënt op een rode knop drukken om de website van PAZIO te presenteren en daarmee het project officieel te laten starten. Zij schrikt zich een hoedje als bij haar druk op de knop er een knal klinkt en er een confettikanon af gaat. Met haar moet ik na deze middag van de schrik bekomen. Mijn ideeën over de ambities en verwachtingen van PAZIO zijn flink opgeschud. ${ }^{159}$ PAZIO staat voor PAtient georiënteerde ZorgInformatie Omgeving, maar blijkt vanmiddag ook een economische motor en een efficiëntiemachine voor de zorg te moeten worden. De voorman van PAZIO, Kuilboer, spreekt bij deze kick-off niet over hoe PAZIO wordt gerealiseerd of over hoe je kwaliteit van zorg en patiënten emancipatie ontwikkelt, maar over hoe je tot innovatie komt. In de wandelgangen hoor ik dat PAZIO van project moet doorgroeien naar een onderneming. De mogelijke functies, doelen en ambities van PAZIO vliegen deze middag door de zaal, maar er wordt daarbij nauwelijks verteld hoe PAZIO dit in de praktijk doet of moet gaan doen. PAZIO lijkt op een black box vol verwachtingen. De afrondende woorden van De Lange voor deze middag zijn treffend: 'nu de ambities nog waar maken'.160

Het blijkt meteen al dat het niet eenvoudig zal zijn om die ambities waar te maken. Als ik bij de afsluitende borrel met De Lange sta te praten, loopt Mevrouw de Wolf langs. De Lange vraagt haar hoe ze de middag gevonden heeft. Ze moet eerst even kwijt dat ze wel erg schrok van dat voor haar onverwachte confettikanon. Daarna vertelt ze dat ze de dag daarvoor voor het eerst geprobeerd heeft PAZIO te gebruiken. Helaas kon ze haar zorgdossier niet inzien. De Lange antwoordt dat dat klopt, daarvoor moet aan zorgverlenerskant nog wel het één en ander gebeuren. ${ }^{161}$ Daarmee heeft hij niets teveel gezegd. Ondanks de veelkleurige ambities en verwachtingen van PAZIO moet er nog veel gebeuren om PAZIO te laten werken in de zorgpraktijk. 


\subsection{DE CONSTRUCTIE VAN HET GELOOF IN PAZIO}

\subsubsection{EEN FILM VOL VERWACHTINGEN}

Tijdens de kick-off bijeenkomst vertelt geen van de sprekers hoe PAZIO werkt of hoe het gezondheidsportaal eruitziet. De vertoonde promotiefilm ${ }^{162}$ geeft wel een rijke impressie van PAZIO, maar tegelijkertijd valt op dat het blijft bij impressies; wat PAZIO is of hoe het werkt wordt niet getoond en wordt ook niet verteld, ondanks het doel van de film: 'stakeholders informeren over de mogelijkheden van PAZIO'.163

De film duurt negen minuten. In die tijd passeren diverse beoogde gebruikers van PAZIO de revue en zij geven een beeld van hun verwachtingen omtrent PAZIO. De stijlelementen van het PAZIO-logo worden door de hele film gebruikt en de kleuren van PAZIO komen terug. De beelden zijn strak, het zijn heldere shots en in de film speelt er continu een zich herhalend muzikaal motief. Door volumewijzigingen wordt de muziek meer op de voor of achtergrond geplaatst, in combinatie met het zich herhalende motief ontstaat zo een naderende ambulance-effect en wordt een sfeer van urgentie opgewekt. In de film horen we een vertrouwenwekkende donkere mannenstem als voice-over. De voice-over suggereert de meerwaarde van PAZIO aan de kijkers en spreekt hen rechtstreeks aan. De film heeft een positief, vertrouwenwekkend karakter en een uniforme en herkenbare look and feel.

De film start met een leader die begint met een korte bumper, waarin het logo van PAZIO wordt geanimeerd. De cirkels uit het logo spelen een belangrijke rol in de animatie: deze verschijnen en bewegen waarna het PAZIO-logo met haar pay off samen werken aan gezondheid in beeld komt. Daarna verschijnen beelden van oudere patiënten die thuis zelftests uitvoeren of achter de computer zitten. Deze beelden worden afgewisseld met screenshots van zorg-ICT-applicaties die logischerwijs van PAZIO zouden moeten zijn. Op de achtergrond van deze beelden draaien de cirkeldelen uit het PAZIO-logo nog door.

Vervolgens wordt ingezoomd op de eerste gebruiker, mevrouw De Wolf. We zien haar voorzichtig door het winkelcentrum van Leidsche Rijn schuifelen en wat moeizaam in haar auto klimmen. Mevrouw de Wolf is hartpatiënt, diabeet, longpatiënt en zeer allergisch voor allerlei dingen. Ik heb toch regelmatig ziekenhuisbezoek, regelmatig bezoek bij de huisarts, 
fysiotherapie, het is niet prettig. Af en toe begin je wel eens zo'n beetje het gevoel te krijgen van: alweer.'

Als mevrouw De Wolf weer in haar auto is gaan zitten, rijdt ze vlot en vol zelfvertrouwen weg. Ze is weer mobiel en kan zich gemakkelijk verplaatsen en bewegen. Dan horen we de voice-over:

'Stel, $u$ wilt als patiënt zelf de regie over uw ziekte en behandeling,

Stel, u wilt als patiënt makkelijk toegang tot al uw gegevens,

Stel, u wilt als patiënt vanuit huis contact met uw zorgverlener.'

Mevrouw De Wolf reageert daarop:

'Voor mijn persoonlijk leven zou dat betekenen dat ik gewoon wat meer vrijheid heb, niet altijd de verplichting heb om naar een arts te gaan omdat je het gewoon via internet kunt vragen of regelen, dus het geeft je meer vrijheid en ook minder verplichtingen.'

Zelf de regie over je ziekte, wie wil dat niet? Ziekte dwingt ons de regie los te laten. Klachten zijn een meer of minder bepalende factor in ons leven. Als door ziekte lichaam en/of geest niet doet wat we willen, dan worden we beperkt in ons doen en laten. Het is goed invoelbaar dat mevrouw De Wolf met haar chronische aandoeningen, de artsenbezoeken die daaraan vast zitten en de vele behandelingen die haar desondanks niet hebben kunnen genezen, de regie terug wil en de suggestie van verlossing met beide handen aangrijpt. Die hoop op bevrijding van het juk van ziekte zullen veel patiënten met mevrouw De Wolf delen. Misschien is het ook veel meer verlossing dan vrijheid waar mevrouw De Wolf op hoopt. Hoe dan ook, PAZIO schept hoge verwachtingen. Niet alleen bij mevrouw De Wolf maar ook bij zeven andere spelers in de zorg en steeds met dezelfde filmische opbouw. Zo zien we Margriet Wanders van CliëntenBelang Utrecht met een kop thee in haar hand door de gangen van het CliëntenBelang kantoor naar haar bureau lopen. Wanders vertelt: 'Mensen gaan vaak zelf zoeken, patiënten worden toch steeds mondiger, die gaan zelf op internet zoeken naar informatie over hun aandoening, enne, nou je weet gewoon niet zeker of het klopt wat je vindt.'

Waarop de voice-over zowel aan- als invult:

'Stel, $u$ wilt betrouwbare informatie over uw aandoening,

Stel, $u$ wilt een snelle signalering en diagnose,

Stel, u wilt als patiënt een digitale toegang tot uw zorgverleners,

Stel, u kunt al deze wensen met één klik van de muis verwezenlijken.' 
Wanders reageert daarop:

'De informatie die op PAZIO staat, als het goed is, is dat hele betrouwbare informatie en dat is natuurlijk niet alle informatie die je vindt als je googled.... Dan weet een doorsnee patiënt niet wat hij wel of niet kan geloven. Een voorziening als PAZIO kan daar een goede rol in spelen.'

Wanders heeft in de film weinig vertrouwen in het vermogen van de doorsnee patiënt om informatie te beoordelen en een groot geloof in betrouwbare informatie. Ze verwacht dat PAZIO daarbij het kaf van het koren kan scheiden en ons kan verlossen van onbetrouwbare informatie.

Hollander is huisarts in het Julius Gezondheidscentrum in het Leidsche Rijn waar ook mevrouw De Wolf woont. Ze werkt daar met veel verschillende disciplines samen. Terwijl we luisteren naar haar verhaal, zien we haar een vlotte jonge patiënte onderzoeken. De systemen zijn volgens haar op dit moment eenzijdig, ze zijn voor de hulpverleners gemaakt, maar de communicatie naar de patiënt en vice versa ontbreekt. Ze zoekt naar manieren om systemen minder eenzijdig te laten zijn, niet alleen gericht op de hulpverleners, maar ook op het contact met de patiënt.

\section{Voice-over:}

- $\quad$ 'Stel, u wilt de patiënt die het echt nodig heeft de juiste aandacht geven,

Stel, u wilt samen met u cliënten aan hun gezondheid werken, Stel, u wilt voorkomen dat uw patiënt onnodig vaak bij u langs moet.'

In het filmpje vertelt Hollander dat PAZIO een internetportaal is, een paraplu waarin een heleboel elementen ondergebracht kunnen worden en die, volgens Hollander, nog veel meer mogelijkheden heeft.

PAZIO kan niet alleen helpen goed en fout te onderscheiden op het internet, maar ook een bijdrage leveren aan het tot stand komen van betrouwbare wetenschappelijke informatie. In de film komt Niek de Wit, huisarts en hoogleraar huisartsgeneeskunde aan het UMCU ons door de gangen van het ziekenhuis tegemoet. Vervolgens zien we hem in zijn werkkamer achter zijn bureau zitten, waar hij op zijn beeldscherm een lijst met referenties uit een wetenschappelijk artikel bekijkt. De Wit doet onderzoek naar invoering van innovaties in de zorg. 'Met de communicatie tussen de onderzoeksgroep en de uitvoerders van onderzoek kun je met digitaliseren nog een hele slag maken.' is zijn verwachting. Ook hier neemt de voice-over het over: 
'Stel, u wilt direct de toegang hebben tot ingevulde patiënten data,

Stel, u wilt af van alle papieren formulieren die traditioneel horen bij onderzoek,

Stel, u wilt meer inzicht in de effectiviteit van e-health, Stel, dat u al deze wensen met één klik van de muis kunt verwezenlijken.'

De Wit reageert:

'Moet je je eens voorstellen wat voor doelmatigheidsslagen je daar telkens mee maakt, want anders moesten we iedereen persoonlijk benaderen, papieren brieven sturen, vragenlijsten laten invullen. En daarmee denken we ook dat de medewerking aan onderzoek enorm zal stijgen, want mensen kunnen het nu ook om half twaalf's avonds doen.'

In het rijtje van gebruikers en door het kort-en-krachtig karakter van de film, waarin naast de inhoud, beeld en geluid minstens zo belangrijk zijn voor de indruk, valt het niet zo op dat deze gebruiker een vreemde eend in de bijt is. De Wit, die later nog een cruciale rol zal spelen in de ontwikkeling van PAZIO, lijkt in de film zelf toch ook even te zoeken naar een geschikte formulering. Doelmatigheidsbevordering van onderzoek als argument voor de ontwikkeling van een patiënt georiënteerde zorginformatie omgeving is weinig overtuigend. In het primaire zorgproces ligt het bevorderen van de doelmatigheid van onderzoek niet direct voor de hand. Onderzoek mag, zo lijkt het, ook een doel op zich zijn en is reden genoeg om daarvoor het portaal te ontwikkelen en benutten.

Naast mevrouw De Wolf, de dames Wanders, Hollander en de heer De Wit passeren nog vijf andere stakeholders de revue, steeds in hetzelfde 'Stel, u wilt' format met voice-over. Hun wensen, verlangens en verwachtingen van PAZIO volgen elkaar in hoog tempo op. Prof.dr. Kahn, afdelingshoofd Psychiatrie aan het UMCU, stelt dat het ' $z o$ ongelofelijk efficient zou zijn als de patiënt van tevoren, voordat hij naar het spreekuur gaat, op het web al een aantal vragen heeft ingevuld en ook kun je diezelfde website gebruiken als de patiënt later (...) toch nog wat vragen heeft. Dan kan je die ook stellen.' Conradi, directeur van de stichting Gezondheidscentra Maarssenbroek heeft als haar 'ideale toekomstbeeld voor deze organisatie dat er een veel betere communicatie komt tussen de eerste, tweede en de derde lijn (...) We moeten van die getallen af en veel meer gaan denken in zorgstraten: onze zorg richten rondom de patiënt en dat moet één communicatiekanaal worden'. Crasborn, directeur Strategie bij Agis zorgverzekeringen, ziet een versnipperde ontwikkeling naar zelfmanagement bij 
patiënten en hoopt dat het digitaal 'op één plek gebeurt en dat mensen weten dat die plek ook integer is, dat het past en dat mensen snappen wie erachter zit.' Florijn, voorzitter van de Raad van Bestuur van het Diaconessenhuis Utrecht, sluit af met dat 'het zou natuurlijk geweldig zijn als we, als PAZIO breed in den lande is geïmplementeerd, met zijn allen een schil om die systemen hebben die gegevens voor ons naadloos integreert.'

Om de cirkel rond te maken en zo de PAZIO-film te omlijsten, komt mevrouw De Wolf als afsluiting na de rondgang langs de gebruikers nog één keer in beeld met een shot dat aan het begin ook is getoond en waarin ze hoopvol verzucht: 'het geeft je meer vrijheid, het geeft je ook minder verplichtingen'. Daarna wordt tot slot de animatie van het PAZIO-logo nog een keer wordt getoond.

De film geeft een kort en krachtig inzicht in de door PAZIO beoogde gebruikers en hun problemen en verlangens, hoop en verwachtingen. De rolprent toont een groot geloof in de vrijheid van mevrouw De Wolf en daarmee de vrijheid van alle patiënten. Mensen moeten los kunnen komen van de banden waarmee ziekte en zorgverlening hen binden. De hoop en verwachting die de film presenteert is dat de verlossende vrijheid, waar mevrouw De Wolf zo naar verlangt, kan worden gerealiseerd met PAZIO. Met één klik van de muis wordt de zorgpraktijk verlost van onbetrouwbare informatie van het internet. Verder ontstaat met dit nieuwe communicatiekanaal in de praktijk een betere communicatie tussen zorgprofessionals onderling en tussen patiënten en zorgverleners en de integratie van systemen leidt tot verbetering van de zorgkwaliteit en hogere efficiëntie.

Wat de film niet doet, is beschrijven wat PAZIO is en aangeven hoe ze haar beloften gaat realiseren. PAZIO wordt op overtuigende wijze gepresenteerd als oplossing voor vele problemen, zonder dat we weten hoe en waarmee PAZIO zaken oplost. We krijgen problemen en wensen gepresenteerd met daarbij slechts de naam van de oplossing, voor de rest komt het aan op vertrouwen, dromen en afwachten. De film geeft geen inzicht in wat PAZIO is, niet hoe ze technisch of praktisch werkt. In deze film waarin het geloof in PAZIO wordt neergezet, is PAZIO zelf de grote afwezige. PAZIO is in deze film een deus ex machina. Hoe is deze film desondanks in staat om PAZIO te promoten bij het academische en in het zorgveld actieve publiek dat aanwezig is bij de kick-off bijeenkomst? De kracht van de film zit ' $m$ in de vormgeving van een onomstreden en aanlokkelijke boodschap van verlossing. 


\subsubsection{DE VERBEELDING VAN PAZIO}

Hoe kan je PAZIO overtuigend positief in beeld brengen, zonder iets over PAZIO zelf te vertellen? Hoe wordt PAZIO in de film verbeeld? Het antwoord komt in een drie-eenheid: PAZIO wordt als verlosser gepositioneerd door een verlossend perspectief te laten presenteren; door vertrouwenwekkende personages waarmee we ons kunnen identificeren; gegoten in een scenario waarin voor dit doel een instant ritueel is gecreeerd.

\section{Verlossend perspectief}

In de beschrijving van de film gebruik ik regelmatig het woord verlossing. Dat woord komt niet uit het empirisch materiaal maar is een onderzoekersterm. Ik gebruik het woord om er een bijzondere verwachting over probleemoplossing mee aan te duiden. Die verwachting heeft een religieus karakter, ze is gebaseerd op geloof. Verlossing gaat om een verwachting van de oplossing van een probleem waarbij de aard en inhoud van de oplossing nog onverklaard of uitgewerkt is. De oplossing is in theatertermen een 'deus ex machina' en vertoont gelijkenis met een goddelijke interventie. In deze casus wordt de interventie niet aan een godheid toegeschreven, maar is PAZIO de interventie. De PAZIO-interventie wordt in de casus soms gepresenteerd als oplossing voor praktische problemen als onjuiste informatie, soms biedt ze verlossing van ziekte en pijn en soms voor meer existentiële kwesties als het verkrijgen van vrijheid. Steeds is echter onduidelijk hoe PAZIO die verlossing 'met een muisklik' gaat realiseren. We worden uitgedaagd in de PAZIO-interventie te geloven, want ze valt nog niet te begrijpen en wordt niet uitgelegd. Om de PAZIO-ontwikkeling te onderzoeken is daarom een religieus perspectief nodig waarin oog is voor verwachtingen en geloof.

De film legt niets uit over de werking van PAZIO, maar schept wel positieve verwachtingen door bij de wensen, problemen en verlangens van de beoogde gebruikers aan te sluiten. Die wensen zijn allemaal op zijn minst invoelbaar en er je kan er met goed fatsoen niet tegen zijn. Sterker nog: als kijker word je zo meegenomen door de suggestie van een oplossing voor de geschetste problemen, dat de eerste neiging is in te stemmen en dit ook te verlangen. Daarbij wordt het droombeeld ook steeds omvangrijker en aantrekkelijker. Met elke actor in beeld wordt het perspectief verlegd, nieuwe beperkingen van de huidige situatie geschetst en de oplossing met 'één muisklik' geboden. PAZIO geeft mevrouw De Wolf haar vrijheid terug, zorgt voor betrouwbare informatie en zorgt dat de patiënt die het echt nodig heeft de juiste aandacht krijgt. PAZIO zorgt dat zorgverleners met hun cliënten samen aan hun gezondheid werken. De eersten kunnen, voorafgaand aan het consult, de klachten van hun patiënt kennen en met hun collega's informatie uitwisselen en delen. Onderzoe- 
kers hebben direct toegang tot ingevulde patiënten data, zijn verlost van alle papieren en formulieren die traditioneel horen bij onderzoek, terwijl ze bovendien meer inzicht in de effectiviteit van e-health krijgen. En PAZIO zorgt voor een efficiënte bedrijfsvoering met een hogere kwaliteit van zorg, een goede informatieuitwisseling in de ketenzorg en meer eigen verantwoordelijkheid voor de patiënt. Deze laatste krijgt, via één digitale toegang, goede informatie over alle gezondheidsaspecten.

Hoe dit alles door PAZIO gerealiseerd zou moeten worden, wordt in de film niet behandeld. Daardoor worden spanningen in het verlossend perspectief voorkomen. De kijkers hoeven niet te kiezen, niet af te wegen of te prioriteren. In de film wordt alles probleemloos achter elkaar gezet. Conflicterende belangen, wensen of verlangens lijken niet te bestaan en tijd en geld spelen alleen een rol als we het hebben over de bijdrage aan een efficiënte bedrijfsvoering. Daar zijn tijd en geld geen probleem, maar juist onderdeel van de oplossing. De vraag hoe de vrijheid van mevrouw De Wolf zich verhoudt tot meer eigen verantwoordelijkheid van de patiënt - of concreter: tot het vooraf informeren van de zorgverlener - is geen onderdeel van het beeld dat hier ontstaat. Zo wordt het mogelijk het beeld van een kleine zorghemel op aarde te schetsen. Je kan er met goed fatsoen niet tegen zijn, sterker nog, wie is er níet voor?

\section{Vertrouwen en sympathie voor personages}

De problemen waar PAZIO een oplossing voor biedt worden door de patiënte en professionals zelf op het scherm aangereikt. Dat geeft de problemen en oplossingen een urgent en reëel karakter. Dit zijn de problemen en wensen van echte mensen, vertellen de beelden ons. Mevrouw De Wolf schuifelt door het winkelcentrum en rijdt in haar auto rond. Dat is wat je mag verwachten in het dagelijkse leven van een bejaarde dame. Zo ligt het in de film ook in de lijn der verwachting dat de hoogleraar psychiatrie iets uitlegt aan een onderzoekster met behulp van een paar hersenscans op een beeldscherm; en de huisarts een jonge dame onderzoekt met behulp van een stethoscoop op haar borst en een spatel in haar mond. Dit is echte zorg en dit zijn echte zorgverleners en patiënten, willen de beelden vertellen. Dat maakt de wensen, verlangens en problemen levensecht en invoelbaar, zo wordt in de film sympathie en vertrouwen gecreëerd. De snelle wisselingen van personages en situaties zorgen ervoor dat we niet de gelegenheid krijgen vragen te stellen bij de beelden. Wat de eerste keer niet opvalt, maar bij nader inzien pas blijkt, is dat de beelden van de zorg wel erg zorgeloos zijn.

Voorafgaande aan de personages krijgen we in het intro beelden te zien, met muziek op de achtergrond, waarin een kwieke oude vrouw thuis een zelftest doet en andere vrouw thuis achter een computer zit, afgewisseld met beelden van screenshots van een zorgportaalpagina. Daarna 
volgen de beelden van de personages. Die beelden gaan vrijwel allemaal over zorg, ideale zorg wel te verstaan. We zien geen hier geen bloed, geen tranen, geen trauma. Als patiënten zien we een vriendelijke oude dame, een energieke jonge vrouw. Ze komen sympathiek over en hebben voor een leek zo op het eerste gezicht geen gezondheidsproblemen. De zorgverleners zijn vriendelijk en creëren geen afstand, maar tonen betrokkenheid. Ze spreken begrijpelijke taal. Deze film gaat niet over de dramatische en complexe kanten van de zorg, deze film verbeeldt een zorgeloze zorg waarin problemen geen problemen zijn of in ieder geval geen onoverkomelijk problemen zijn. Hier worden gezondheidsproblemen opgelost, hier wordt vrijheid en verlossing beloofd.

De personages worden in de film los van elkaar gepresenteerd, maar tegelijkertijd met elkaar verbonden in het verband van de film. Ook in het dagelijks leven zijn ze geen vreemden voor elkaar. Het merendeel van de personages speelt ook op andere wijze een rol in het project PAZIO. Mevrouw De Wolf is lid van het klantenpanel, Hollander en De Wit zijn betrokken bij de implementatie van PAZIO bij de Leidsche Rijn Julius Gezondheidscentra, Kahn is enthousiast gebruiker van de eConsult module die ook in PAZIO gebruikt moet gaan worden. Het Gezondheidscentra Maarssenbroek waar Conradi directeur is, is een van de early adopters van PAZIO. Deze personages ontmoeten elkaar in de Utrechtse gezondheidszorg, bij het UMCU en zijn ieder geval verbonden door hun gedeelde vertrouwen en betrokkenheid bij PAZIO. Ze vormen een kleine gemeenschap van mensen die geloven in PAZIO en dat willen uitdragen. Ze zijn de innovatoren en early adopters van PAZIO, maar in deze film zijn ze primair de pleitbezorgers die de komst van verlosser PAZIO aankondigen en hoop verkondigen.

\section{Instant rituelen}

Het enige personage dat in de film aanwezig is, maar geen patiënt of professional is en geen beeld of context kent is de voice-over. Die vertelt ons met een vertrouwenwekkende donkere stem het verhaal van de verlossing 'Stel, dat u al deze wensen met één klik van de muis kunt verwezenlijken'. Die stem kent geen plaats of tijd, het is als een verlossende stem uit de hemel, die in de film de kijkers aan de hand neemt. De stem wordt kracht bijgezet doordat ze in de film in een herkenbaar schema steeds opnieuw terugkeert, waardoor de boodschap steeds omvangrijker, krachtiger en vertrouwder wordt. Het schema is stel, $u$ wilt..., stel, $u$ wilt, ...stel, $u$ wilt ... al dan niet afgerond met Stel, dat u al deze wensen met één klik van de muis kunt verwezenlijken. In dit schema wordt er eerst een toekomstbeeld gecreëerd, waarin een probleem dat we nu hebben wordt opgelost. Er wordt een beetje verlossing voorgeschoteld. Dat wordt nog eens herhaald 
bij een tweede en soms derde probleem. Dat maakt haar nog aanlokkelijker. Het gevoel: 'dit moeten we gaan doen' wordt opgeroepen. Mensen worden zo geëngageerd aan het geboden perspectief. Zeker als dit ook nog eens zo eenvoudig lijkt: je kan het met één muisklik verwezenlijken. Dat is een aanbod dat je niet af kan slaan. Tegelijkertijd kan een aanbod dat te mooi lijkt, ook wantrouwen en twijfel oproepen.

Die twijfel wordt voor een deel weggenomen doordat verschillende professionals op vertrouwenwekkende wijze in beeld komen en zich verbinden aan de boodschap en aan PAZIO. Minstens zo belangrijk is echter dat er een vertrouwenwekkend ritueel wordt gecreëerd. Met het passeren van de verschillende personages doorlopen we steeds dezelfde cyclus stel u wilt, stel u wilt, stel u wilt, ...met één muisklik ... verwezenlijken. Het patroon is even eenvoudig als effectief, het is herkenbaar. De kijker kan het snel overzien en beheersen en dat geeft houvast en vertrouwen. Met het beheersen van de cyclus, gaat de cyclus ook ons beheersen. Het is vergelijkbaar met het bidden van een rozenkrans in de rooms katholieke traditie of met de rituele ronde die boeddhisten maken langs hun gebedsmolens: ondanks alle onzekerheden en vragen weet je wat je moet doen en weet waar je waar bent. In het vertrouwde meegaan in de cyclus, ontstaat het vertrouwen in de cyclus. We krijgen geen idee van PAZIO, maar het ritueel voelt snel vertrouwd en dat versterkt het vertrouwen in de belofte van PAZIO.

Toch is de verlossing die PAZIO belooft niet helemaal abstract en niet alleen gebaseerd op vertrouwenwekkende personages en rituelen. Het is meer dan een stem. Van de zorgportaal screenshots mogen we als kijker aannemen (en kan een kenner bevestigen) dat het screenshots van PAZIO zijn. Daarnaast begint en eindigt de film met het logo en de pay off van PAZIO (zie fig. 3.1). Er is een beeld voor PAZIO. Omdat dit beeld geen inkijk geeft in de werking of mogelijkheden van PAZIO blijft PAZIO een blackbox. Maar het is wel een blackbox met daarop een logo, een icoon, waarmee PAZIO zichtbaar en herkenbaar wordt.

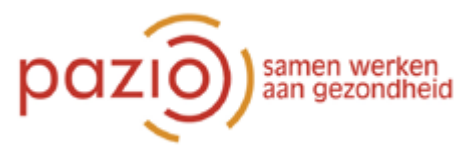




\section{Promotiefilm vol verlossing en verlangen}

De PAZIO-film is geen voorlichtingsfilm of documentaire, maar beter te karakteriseren als een promotiefilm of lange reclamespot: een reclamespot waarin gespeeld wordt met het idioom van een voorlichtingsfilm. De film speelt primair in op de gevoelens en het gemoed van de kijkers en pas daarna op zijn of haar kennis. Er worden dan ook geen feitelijkheden gecommuniceerd, maar er worden waarden, idealen en overtuigingen gedeeld. Zoals Coca-Cola verkocht wordt met een vrolijk levensgevoel en spots vol mooie jonge mensen, zo wordt PAZIO verkocht door zorgprofessionals en patiënten die geloven in vrijheid. We hebben het daarbij noch over de smaak van Coca-Cola, noch over de functionaliteit van PAZIO en zelfs niet over wat een vrolijk levensgevoel of vrijheid in de praktijk concreet gaat betekenen. Het enige dat we concreet van PAZIO zien is dan ook haar logo met de pay off samen werken aan gezondheid. Het PAZIO-logo wordt verbonden aan de geproclameerde waarden. Bij reclame gaat om het creëren van positieve associaties bij het product en de achterliggende waarden, niet om het product of de waarde zelf. Daarmee schiet de film wel haar in het script vastgelegde doel voorbij: 'stakeholders te informeren over de mogelijkheden van PAZIO'.164

De personages in de film spelen zichzelf, maar vertellen niet vanzelfsprekend ook hun eigen verhaal in de film. In het script stond al aangegeven welke beloften van PAZIO aan bod moesten komen. De personages worden in de film in een interviewsetting geplaatst. Ze vertellen zelf en daarmee wordt de indruk gecreëerd dat ze hun eigen boodschap brengen. De gepresenteerde wensen en verwachtingen komen echter niet alleen van de personages, maar waren al onderdeel van het script. Dat script is dat door het projectteam in samenwerking met het audiovisueel productiebedrijf ${ }^{165}$ opgesteld, waarbij de inhoud grotendeels van het projectteam komt. Het projectteam spreekt via de personages. De personages moeten niet slechts zichzelf zijn maar ook acteren om het gewenste effect in de film tot stand te brengen. Zoals PAZIO-projectleider De Lange opmerkt bij het script: 'Om dat soort quotes te verkrijgen, ... zullen de actoren ook echt moeten acteren. PAZIO is namelijk nog niet lang in gebruik en zal ook nog flink moeten worden uitgebreid.' ${ }^{166}$ 


\subsection{ONTWIKKELING VAN HET GELOOF IN PAZIO}

\subsubsection{EEN PATIËNTGEORIËNTEERDE VIRTUELE ZORGINFRASTRUCTUUR VOOR PARTICULIERE BELANGEN}

In het begin waren er woorden en geïnspireerde gedachten, maar er was nog geen naam, geen uitgewerkt idee of te vertellen verhaal. Laat staan dat er een plan, project of product was. PAZIO bestond nog niet. Er waren slechts wilde ideeën, een leeg vel papier en de gedachte om met behulp van een subsidie van inspiratie naar een plan te komen. Voor de ontwikkeling van PAZIO blijken al dan niet gehonoreerde subsidieaanvragen van groot belang geweest te zijn. Het waren subsidievoorstellen die zorgden dat de onrijpe ideeën in verhalen getransformeerd werden en dat verhalen in plannen op papier werden omgezet. In deze paragraaf laat wordt zichtbaar hoe subsidieprogramma's kristallisatiepunten waren om interne inspiraties, extern geloofwaardig te maken; hoe een diversiteit aan idealen en mensen zich rond PAZIO verzameld worden en hoe dat PAZIO vormt.

In 2006 wordt vanuit het ministerie van Economische Zaken het meerjarig gebiedsgerichte economische programma Pieken in de Delta uitgeschreven. Het is een subsidieregeling voor regionale economische stimulering. De regio Noordvleugel Randstad omvat het gebied rond Utrecht, Amsterdam en Haarlem. De stimuleringsregeling is hier gericht op onder andere stimulering van het medisch cluster en ICT. ${ }^{167}$ Het UMCU en enkele aan haar verbonden partijen zien hierin een kans om te komen tot de ontwikkeling van wat genoemd wordt een Patiëntgeoriënteerde Virtuele Zorginfrastructuur. ${ }^{168}$

In november 2006 schrijft IT-programmeur en consultant Rietveld in opdracht van Mediportaal een notitie over deze Patiëntgeoriënteerde Virtuele Zorginfrastructuur (PVZ); de voorloper van PAZIO. ${ }^{169}$ In de notitie worden als vertrekpunt de behoeften de belangen van de betrokken partijen genomen en geordend:

'Mediportaal wil een nieuwe release van eConsult ontwikkelen; ...

167 RVO. Pieken in de Delta subsidieregelingen. Website, Geraadpleegd 4 februari 2015

168 Dekker, Verslag bespreking PAZIO 9 oktober 2007. Tekstdocument, 9 oktober 2007.

169 Rietveld en Mediportaal. Voorstel "Patiëntgeoriënteerde Virtuele Zorginfrastructuur".

Tekstdocument, 9 november 2006. 
Vanuit het Julius Centrum is er de wens om online research formulieren te kunnen gebruiken t.b.v. wetenschappelijk onderzoek in de Utrechtse wijk Leidsche Rijn;

UMC Utrecht en AGIS delen de strategische visie dat de patiënt meer de regie zou moeten krijgen in de eigen zorg; dit laat zich vertalen in de wenselijkheid van een portaalinfrastructuur die dat ondersteunt; ${ }^{170}$

De realisatie van de PVZ wordt door de auteurs alleen mogelijk geacht als grotere spelers in de zorgmarkt en belangenorganisaties met elkaar samenwerken in plaats van elkaar beconcurreren. Daarbij zou een grote relatief neutrale kennisorganisatie als UMC Utrecht geschikt zijn om de kar te trekken. De andere partijen zijn nauw aan het UMCU gelieerd. Het Julius Centrum voor Gezondheidswetenschappen \& Eerstelijnsgeneeskunde is een divisie van het UMCU. Mediportaal is een B.V. opgericht onder de vleugels van het UMCU en richt zich op ICT-ontwikkeling voor de zorg. AGIS is een zorgverzekeraar en onderdeel van Achmea, de grootste zorgverzekeraarsgroep in Nederland, met in 2006 een marktaandeel van zo'n $25 \%$ in de provincie Utrecht. ${ }^{171} \mathrm{Ze}$ is daarmee ook de grootste verzekeraar in deze provincie en een belangrijke gesprekspartner voor het UMCU.

Het UMCU is een grote zorg- en onderzoeksorganisatie die haar zorgen onderzoekswerk alleen kan doen in nauwe samenwerking met de regio. Het PVZ is primair op de eerste lijn gericht, en is voor het UMCU een middel om een digitale verbinding te leggen met de zorg in de regio. Zo versterken ze hun adherentiegebied te versterken en kunnen zij werken aan goede zorg en kennisontwikkeling. Het aan het UMCU gelieerde eerstelijns onderzoeksinstituut Julius Centrum is gericht op kennisontwikkeling; voor dit centrum kan een PVZ het mogelijk maken om eenvoudiger patiënten te rekruteren en data te verzamelen. Dat wordt nog eenvoudiger als in deze fase ook een nieuwe participant om de hoek komt kijken, de Leidsche Rijn Julius Gezondheidscentra (LRJG). LRJG is mede opgericht door het UMCU en 'wil een belangrijke bijdrage leveren aan de ontwikkeling van nieuwe (para) medische kennis op academisch niveau, de gerichte toepassing van deze kennis in de dagelijkse praktijk en de overdracht van kennis en vaardigheden aan huidige en toekomstige zorgverleners.' LRJG verwacht met behulp van het PVZ de kwaliteit van dienstverlening en klantenbinding te vergroten en research en zorg te integreren. Voor het

170 Rietveld en Mediportaal. Voorstel "Patiëntgeoriënteerde Virtuele Zorginfrastructuur".

Tekstdocument, 9 november 2006, 1.

171 Nederlandse Zorgautoriteit, 'Zienswijze (openbare versie) Concentratie zorgverzekeraars Agis,

Menzis en Delta Lloyd'. 
Julius Centrum ${ }^{172}$, dat niet voor niets dezelfde naamgever heeft als het Leidsche Rijn Julius Gezondheidscentrum, biedt LRJG een prachtige uitvalsbasis voor haar Leidsche Rijn Gezondheidsproject (LRGP) in de grote VINEX-wijk Leidsche Rijn in Utrecht. Het PVZ kan die wijk digitaal ontsluiten. ${ }^{173}$ Voor Mediportaal biedt het PVZ een nieuw project en de mogelijkheid om haar eerdere softwareproducten te vermarkten. De partners zien elk vanuit hun eigen professionele identiteit de waarde van het PVZ voor hun primaire proces. Er is echter nog geen sprake van gedeeld belang of van een gezamenlijke visie op het PVZ.

In de notitie van Rietveld wordt aangegeven dat er een paar belangrijke ontwikkelingen gaande zijn binnen het Nederlandse zorglandschap. De marktwerking neemt toe: instellingen concurreren om de patiënt, die zal moeten kiezen uit een groeiend aantal zorgaanbieders. Het centraal elektronisch patiëntendossier (EPD) is in ontwikkeling: hierdoor zal de patiënt behoefte krijgen aan advies en ondersteuning bij de omgang met zijn eigen medische dossier. Ook is de verwachting dat er een breed scala aan e-health toepassingen ontwikkeld zal worden in aansluiting op dit EPD. Op basis van deze ontwikkelingen zijn de schrijvers tot de volgende visie op de ontwikkeling van een patiënt georiënteerde zorginfrastructuur gekomen:

'De patiënt komt centraal te staan in de zorgmarkt, maar zijn positie is tegelijk kwetsbaar.

De huisarts wordt gezondheidscoach: de huidige poortwachter functie zal verschuiven naar een soort 'broker'-functie, hij adviseert en ondersteunt de patiënt in de selectie van zorgaanbieder en zorgverzekeraar en adviseert t.a.v. de toegang tot de eigen medische data.

De patiënt is sterk gebaat bij een informatie- en applicatie-infrastructuur die hem ondersteunt in de regierol t.a.v. de eigen zorgbehoefte

Deze infrastructuur is verder nodig als integratiepunt of 'kapstok' voor de diverse e-health toepassingen die in de markt al tot ontwikkeling zijn gekomen of nog zullen worden ontwikkeld door de diverse partijen. ${ }^{174}$

172 Het Julius Centrum is het centrum van het UMCU voor gezondheidswetenschappen en eerstelijns Geneeskunde. Het Julius Centrum is vernoemd naar Henri Willem Julius (1901-1977), hoogleraar Gezondheidswetenschappen en rector aan de Universiteit van Utrecht. Julius Centrum, 'Julius Centrum'.

173 Rietveld en Mediportaal. Voorstel "Patiëntgeoriënteerde Virtuele Zorginfrastructuur". Tekstdocument, 9 november 2006.

174 Rietveld en Mediportaal. Voorstel "Patiëntgeoriënteerde Virtuele Zorginfrastructuur". Tekstdocument, 9 november $2006,2$. 
Dat de patiënt centraal komt te staan in de zorg is in deze notitie een vooronderstelling en geen ideaal om aan te werken. Ze wordt hier opgevoerd als een argument voor de ontwikkeling van het Patiëntgebonden Virtuele Zorginfrastructuur. Doordat de patiënt centraal komt te staan, is er behoefte aan een PVZ. Het centraal stellen van de patiënt dat als ideaal in de film zo pregnant naar voren zal komen, is in deze fase van de ontwikkeling als ideaal nog volledig afwezig.

In het eerste schema van het PVZ (zie fig. 3.2) krijgt de patiënt ook geen centrale plaats. Onder de noemer 'gebruiker' komt hij wel terug in het schema, maar heeft daarin weinig gewicht en staat allerminst centraal. De gebruiker is bovenaan aan de rand gepositioneerd en is slechts op één punt via een paar dunne lijntjes met het uit grote blokken bestaande PVZ-systeem verbonden. In het schema staat het systeem zelf centraal en leggen de patiënt en de zorgpraktijk nog weinig gewicht in de schaal. Het is de technische innovatie die hier verbeeld wordt. De betekenis daarvan voor de gebruikers of de zorgpraktijk blijft onbesproken.

Dat beeld wordt versterkt in de uitwerking van de uitgangspunten voor een Patiëntgeoriënteerde Virtuele Zorginfrastructuur (PVZ). Die uitgangspunten geven een functionele beschrijving van het PVZ. Ze laat zien wat het PVZ technisch kan (identificatie en authenticatie voor patiënt en zorgverleners, ontsluiten van functionaliteiten) en is (een generieke portaalfunctionaliteit), maar niet wat ze doet in de zorgpraktijk. De notitie schetst een technische structuur, zonder dat ze inzicht in de betekenis of waarde daarvan voor de praktijk geeft. Daarmee komt de eerste notitie niet verder dan het behartigen van de belangen van de betrokken stakeholders en blijft de maatschappelijke meerwaarde grotendeels uit zicht. Er is hier nog geen sprake van een gedeelde inspiratie voor het te ontwikkelen PVZ, vooralsnog is het een pragmatische investeringsoptie waar de betrokken participanten baat bij kunnen hebben. Het voorstel is gebouwd op technische uitgangspunten en stakeholder belangen. De participanten vinden elkaar in de vereniging van hun welbegrepen eigenbelangen in het PVZ; ze hebben echter nog geen verbindend ideëel verhaal of gedeelde ambitie waarin ze elkaar vinden, begrijpen en betrekken. Daarmee heeft de notitie nog weinig richting en ontbreekt overtuigingskracht om het PVZ als waardevol te presenteren en derden daarbij te betrekken. De aanleiding om de notitie te schrijven was het zicht op subsidie. Tot een subsidieaanvraag voor Pieken in de Delta 2006 is het nooit gekomen, maar dat wil niet zeggen dat de notitie voor het PVZ geen meerwaarde heeft. Met de notitie hangt het idee voor een PVZ niet langer in de lucht, maar staat het nu in woord en beeld op papier. 


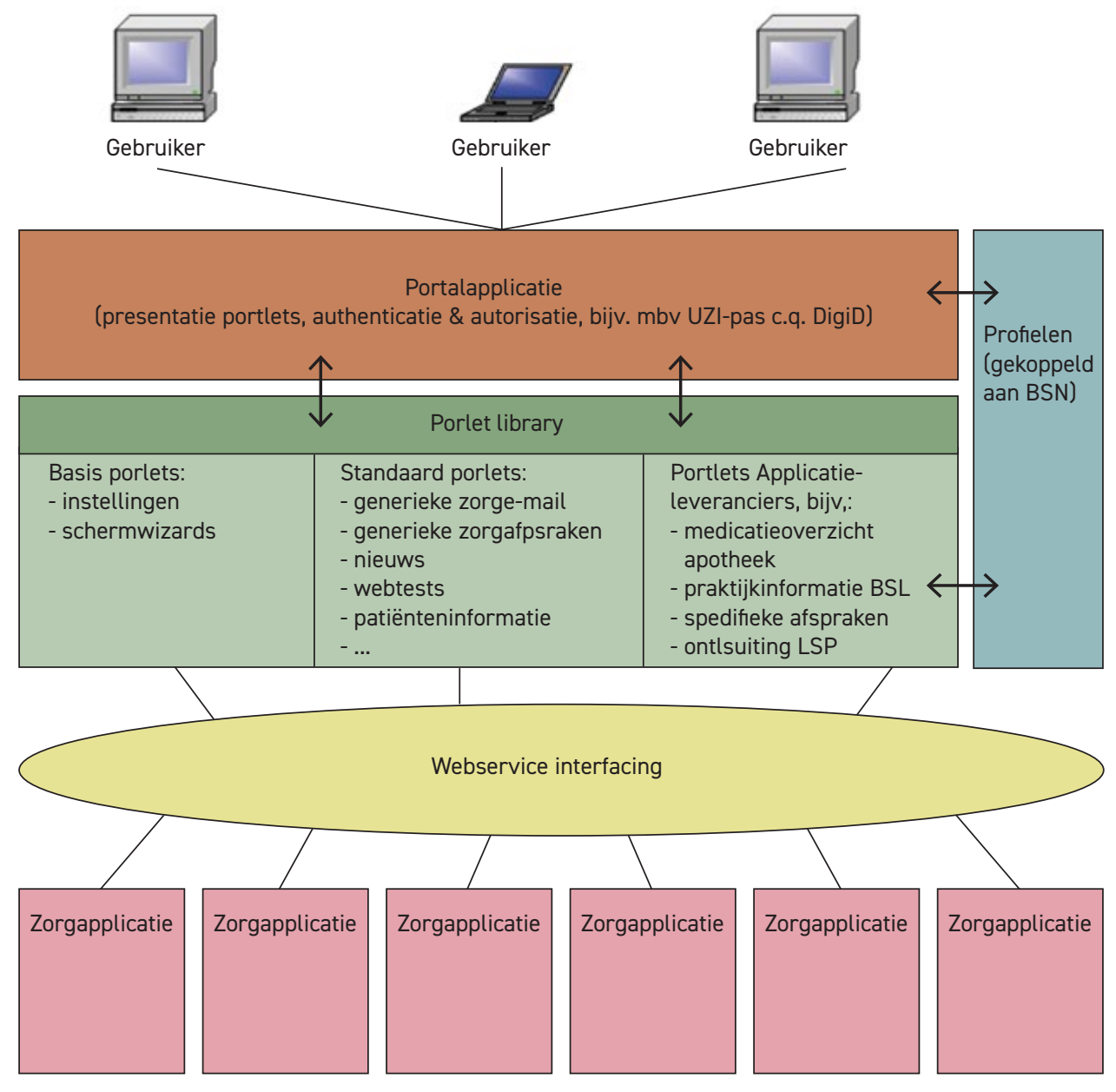

FIGUUR 3.2 Schema voor het PVZ. ${ }^{175}$

Een al verder uitgewerkt conceptplan voor het PVZ, opnieuw van de hand van Rietveld, verschijnt in juni 2007.176 Waar de vorige notitie weinig aandacht gaf aan de context en meerwaarde van het PVZ opent deze notitie direct met een beschrijving van de meerwaarde van het beoogde PVZ. 
'In dit document wordt het concept uitgewerkt voor de 'Patiëntgeoriënteerde Virtuele Zorginfrastructuur' ( $P V Z$ is een voorlopige werknaam; voorstellen zijn Portus Cura of PAZIO: Patiëntgeoriënteerde Zorg Informatie Omgeving). Dit is een portaalapplicatie waarbinnen e-health applicaties van uiteenlopende aanbieders in de zorgmarkt een plek kunnen krijgen, Doordat de gebruiker voor het geheel inlogt en niet voor de losse onderdelen, ontstaat een meerwaarde t.o.v. de huidige situatie op het Internet, waar iedere zorgverlener een eigen site heeft en de gebruiker steeds een andere account moet gebruiken. ${ }^{177}$

Het PVZ biedt de gebruiker de mogelijkheid om zijn zorg online vanuit een portaal te regelen en niet langer bij verschillende zorgverleners verschillende account moet aanmaken. Met het PVZ komt de gebruiker centraal te staan, dat wordt ondersteund met een illustratie (zie fig. 3.3)

Dat de gebruiker centraal staat wordt in de figuur op twee manieren duidelijk gemaakt. Allereerst door de centrale positionering van de gebruiker in de figuur. En daarnaast door de verbeelding van de gebruiker. De gebruiker is hier afgebeeld als een menselijk poppetje en niet langer als een laptop met het woord gebruiker eronder, zoals we hiervoor in figuur 3.2 zagen. In deze figuur wordt het gebruikersgemak voor de gebruiker van het PVZ verbeeld en daarmee om de meerwaarde en ambitie van het PVZ.

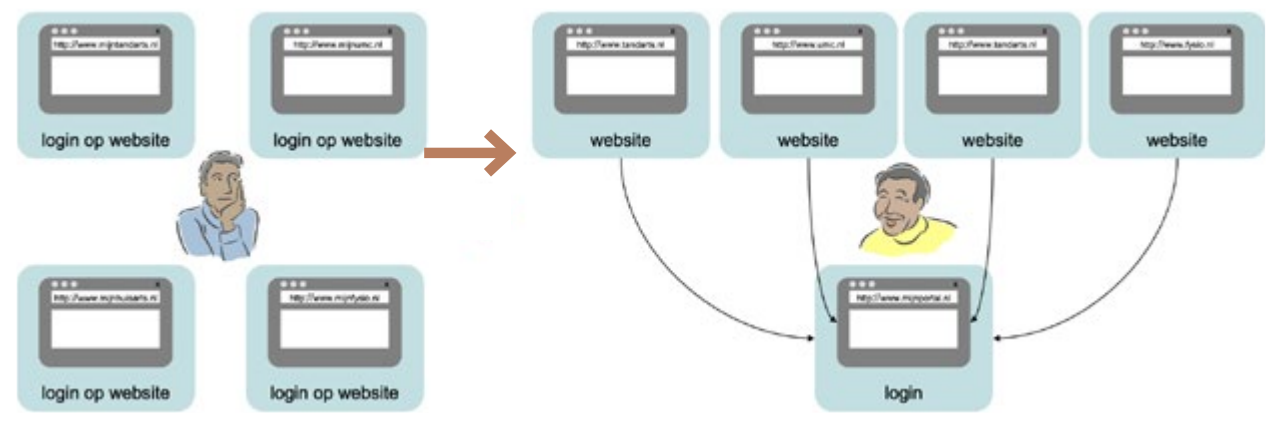

FIGUUR 3.3 De veranderende positie van de gebruiker.

De centrale positie van de gebruiker vertaalt zich ook in de suggesties voor productnamen voor het PVZ. Gesuggereerd worden de namen 
Portus Cura en PAZIO. Portus Cura horen we niet meer terug, er wordt gekozen voor PAZIO: een acroniem voor PAtient georiënteerde ZorgInformatie Omgeving. In de naam wordt bevestigd dat de het systeem zich oriënteert op de patiënt en deze centraal gesteld wordt. De naam PAZIO wordt een dragend begrip voor de ontwikkeling en is het eerste gerealiseerde onderdeel van PAZIO.

De centrale positie van de patiënt is echter niet absoluut: in de notitie wordt gesproken over gebruikers en niet over patiënten. In de beoogde praktijk van PVZ zijn er twee soorten gebruikers, waarvan er één groep betaalt voor de dienst. In de zorgpraktijk komt de patiënt met het PVZ centraal te staan, op de zorgmarkt staat voor het PVZ echter de zorgverlener als betalende gebruiker centraal. 'De belangrijkste doelgroep voor de dienst zijn de eerstelijns zorgverleners. De PVZ biedt een platform voor een geïntegreerde communicatie met de patiënt, met andere collega's en andere partijen. ${ }^{178}$ Zo ontstaan er twee doelgroepen: de patiënt als gebruiker en zorgverlener als gebruiker en financier. Zoals we later zullen zien geldt ook op deze markt het adagium: wie betaalt bepaalt.

\subsubsection{SUBSIDIEAANVRAAG MEICT: PAZIO ALS DOORBRAAKMACHINE VOOR SYSTEEMFALEN}

Parallel aan het PVZ-notities wordt een subsidieaanvraag ingediend voor het Actieprogramma Maatschappelijke Sectoren en ICT (M\&ICT). Dat is een programma van de ministeries van BZK, Justitie, OCW, V\&W, VWS en EZ en loopt van 2005 tot 2009. Met het actieprogramma wil de overheid belemmeringen in verschillende maatschappelijke sectoren aanpakken door de inzet van ICT, met name door de opschaling van bestaande ICT-oplossingen. ${ }^{179}$ In 2008 is het programma er daarnaast expliciet op gericht om systeemfalen ${ }^{180}$ te doorbreken. Het actieprogramma M\&ICT toont grote verwachting van innovatie en een groot geloof in ICT.

De Pieken in de Delta subsidie was in 2006 niet meer dan een aanleiding om de gedachten over iets zoals het PVZ op papier te zetten, er is nooit geprobeerd een daadwerkelijke aanvraag te schrijven. Bij het M\&ICT-subsidieprogramma is dat anders. Er wordt in een daadwerkelijke aanvraag geschreven. ${ }^{181}$ De kaders en het format van M\&ICT zorgen

178 Rietveld, Concept ontwikkeling PVZ. Tekstdocument, 26 juni 2007, 3.

179 'Over M\&ICT'.

180 Daaronder verstaat men: 'Systeemfalen doet zich voor als verschillende problemen in onderlinge samenhang zorgen voor het voortduren van een ongewenste situatie.' Zie: PAZIO, Concept projectvoorstel PAZIO voor M\&ICT. Tekstdocument, mei 2007.

181 PAZIO, Concept projectvoorstel PAZIO voor M\&ICT. Tekstdocument, mei 2007. 
ervoor dat het PVZ opnieuw doordacht en beschreven wordt. KPN, één van de noodzakelijke partners in de aanvraag, trekt zich echter op het laatste moment terug. Hierdoor kan de aanvraag niet ingediend worden. De opgestelde subsidieaanvraag geeft wel een nieuwe, op de buitenwereld gerichte blik op het PVZ. De gezamenlijke overtuiging dat de patiënt centraal moet komen te staan in de zorg wordt gepresenteerd. In het verlengde daarvan wordt de term PVZ hier niet meer gebruikt, maar definitief vervangen door PAZIO: Patiëntgeoriënteerde Zorg Informatie Omgeving. De naam PAZIO bevestigt en representeert de overtuiging dat de patiënt centraal moet komen te staan. De focus in de M\&ICT-aanvraag ligt echter primair op de maatschappelijke meerwaarde van PAZIO en het daarmee streven naar maatschappelijke doorbraken en vooruitgang. Het voorstel opent met de presentatie van PAZIO, haar basisovertuigingen en ambities.

'De patiënt/cliënt als spil in de keten is het uitgangspunt van PAZIO, een zorginfrastructuur waarin drie bestaande diensten worden geïntegreerd en waaraan na opschaling ook andere relevante onlinediensten kunnen worden toegevoegd. De ambitie van PAZIO is om hét nationale gezondheidsportaal te zijn! ... Dit leidt naar verwachting tot kwaliteitsverbetering van de zorg en betere preventie, zodat de patiënt/cliënt langer gezond thuis kan functioneren. De patiënt/cliënt hoeft de diensten niet meer bij iedere zorgverlener afzonderlijk te halen; zij brengen hun diensten via PAZIO bij de patiënt/cliënt. ${ }^{182}$

PAZIO gelooft in de patiënt en in vooruitgang in de zorg en presenteert haar bijdrage daaraan. Het actieprogramma M\&ICT vraagt echter meer dan dat. Het streeft naar het doorbreken van systeemfalen; het idee dat het maatschappelijk systeem faalt in het benutten van die innovatieve mogelijkheden. De achterliggende overtuiging in het M\&ICT-programma is dat de mogelijkheden van ICT bijdragen aan maatschappelijke ontwikkeling.

In de PAZIO-aanvraag wordt dat geloof in vooruitgang en innovatie met behulp van ICT overgenomen. Ze erkent het systeemfalen in het zorgsysteem en presenteert zich als een platform dat werkt als een doorbraakmachine. Ze formuleert een systeemprobleem en profileert ze zichzelf als de oplossing daarvoor.

'De bestaande diensten E-Consult, Patiëntenzelfmanagement en Research Online zijn succesvol, maar door systeemfalen 
is afzonderlijke opschaling niet gelukt. Het creëren van een overkoepelende portaalapplicatie waarin deze diensten worden samengevoegd heft het systeemfalen op, waardoor opschaling realiseerbaar is. Na een succesvolle integratiefase is het concept in heel Nederland toepasbaar en kunnen meerdere succesvolle diensten m.b.v. dit platform opschalen.' ${ }^{183}$

Met PAZIO kan dit falend systeem doorbroken worden, zo wordt gesteld. Daarmee wordt PAZIO opnieuw uitgevonden. Om het systeemfalen te doorbreken en vraag en aanbod bij elkaar te brengen wordt er een 'geïntegreerde informatie- en applicatieinfrastructuur' ${ }^{184}$ geboden, die de patiënt/cliënt ondersteunt in de regierol in de zorgketen. Er vormt zich wat wel genoemd wordt een 'Personal Health Record' (PHR)', ${ }^{185}$ waarmee de zorg verbetert door het leveren van relevante informatie, online communicatiemogelijkheden, preventieverbetering en zelfmanagement door de patiënt. Daarmee ontstaat vraagmacht: de vraag van de patiënt speelt een sterkere rol op de markt voor online zorg. Voor de leveranciers ontstaat in deze beweging een 'leveranciersonafhankelijke e-healthinfrastructuur ${ }^{186}$ waarop zij hun onlinediensten kunnen aanbieden. Dat bespaart de leveranciers kosten om zelf de link naar de patiënt te leggen en maakt toetreding tot de markt eenvoudiger. Zo'n geïntegreerde vorm van onlinedienstverlening levert voor de patiënt gemak op en zorgt voor een besparing voor de leveranciers; die hoeven dankzij PAZIO niet ieder voor zich de verbinding naar de patiënt te leggen.

Doordat PAZIO de patiënt centraal zet wordt vraagmacht gecreëerd op de e-health-markt. Daarnaast werkt PAZIO als een afzetkanaal en infrastructuur voor leveranciers. Zo profileert PAZIO zich als doorbraakmachine voor systeemfalen in de zorg.

Het centraal zetten van de patiënt is hier primair van belang is om het marktfalen te doorbreken. Dat wordt ook zichtbaar in de figuren die de argumentatie ondersteunen. De doorbraak van het systeemfalen wordt toegelicht met figuur 3.4. PAZIO vormt zich in deze figuur niet om de patiënt heen maar levert een laag tussen de patiënt en verschillende onlinediensten, waarbij de suggestie is de leveranciers via die tussenlaag de patiënt eenvoudig kunnen bereiken met hun productaanbod. Als figuur 3.4 zou moeten verbeelden dat PAZIO de patiënt centraal stelt, zou ze weinig overtuigen. In de schets wordt de patiënt eerder geïsoleerd dan 


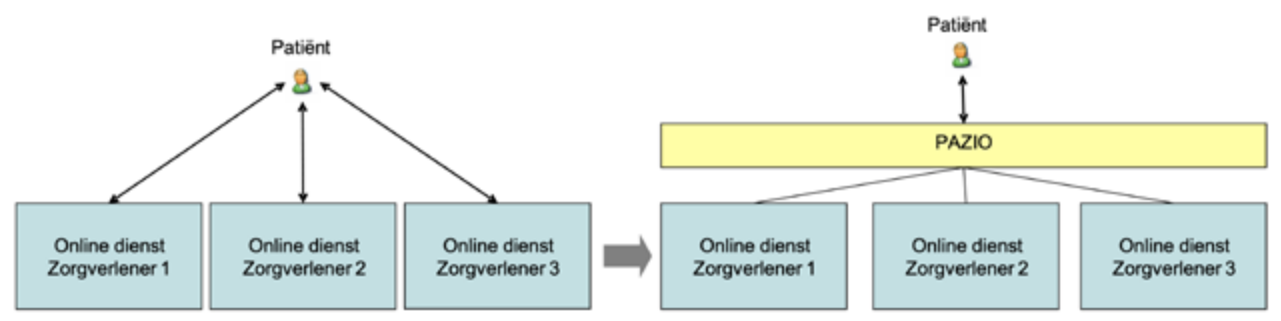

FIGUUR 3.4 Geïntegreerde informatie- en applicatieinfrastructuur. ${ }^{187}$

centraal gesteld door PAZIO. De patiënt centraal stellen is dan ook niet het doel van de figuur. De figuur verbeeldt hoe PAZIO het bereiken van de gebruiker faciliteert en zo de markt ontsluit voor e-health-leveranciers.

Die tussenlaag is in dit kader ook dan ook beter te begrijpen als een leveranciers onafhankelijke e-health infrastructuur' dan als een 'patiënt georiënteerde zorg informatie omgeving'. Die onafhankelijke e-healthinfrastructuur moet helpen het not invented here-syndroom in de zorg te doorbreken.

'Veel partijen ontwikkelen hun eigen applicaties, omdat ze geen vertrouwen hebben in toepassingen die van elders komen. ... Door de patiënt/cliënt centraal te stellen organiseren we vraagmacht. Dit werkt als een pullmechanisme naar zorgaanbieders/-leveranciers. ${ }^{188}$

Op basis van voorgaande kunnen we concluderen dat het uitgangspunt 'de patiënt centraal' hier niet zozeer als doel op zich gebruikt, maar als middel tot het realiseren van een doorbraak in het systeemfalen. PAZIO is dus hier niet zozeer een oplossing om te komen tot patiëntenemancipatie, hier is ze een 'leveranciers onafhankelijke e-health-infrastructuur' die werkt als doorbraakmachine in de falende zorgmarkt. Als we de kern van bovenstaande analyse samenvatten dan hebben de emancipatie- en doorbraakmachine gemeen dat ze gebaseerd zijn op het geloof dat dezelfde techniek de oplossing biedt om idealen te verwezenlijken. PAZIO is een motor voor de economie, een emancipatiemachine voor het individu en een katalysator voor zorgverbetering zo is de al dan niet 
impliciete vooronderstelling.

Als we de PVZ-notities en het M\&ICT-voorstel vergelijken vallen een paar dingen op. In de PVZ-notities is het vertrekpunt een optelsom van de particuliere belangen van de participanten, waarbij het geheel niet groter is dan de som der deelbelangen. Dat verandert in het M\&ICT-voorstel, daarin ontstaat een groter algemeen belang, de ambitie om daaraan met PAZIO bij te dragen en maatschappelijke impact te hebben. In die lijn is het ook goed te begrijpen dat het PVZ nog werd gepresenteerd als neutrale techniek die goed aansloot op de ontwikkelingen in de zorg, terwijl PAZIO in het M-ICT-voorstel wordt gepresenteerd als emancipator en doorbraakmachine. Dat past goed in een fase waarin men met PAZIO naar buiten treedt en nieuwe partijen en subsidieverleners probeert aan te laten haken. Het is daarbij voor de hand liggend dat juist hier ambities en vergezichten ontstaan die de particuliere belangen overstijgen. Opvallend is daarbij wel dat PAZIO hier sterk met de subsidiewinden mee waait. Er lijken nog onvoldoende grondmotieven ontwikkeld om zelfstandig en stevig te staan.

\subsubsection{DE PROGRAMMAOPZET PAZIO: DE BLIK NAAR BINNEN}

Op 9 oktober 2007 is er een 'bespreking PAZIO' waar voor het eerst ook Florijn namens VitaValley aanwezig is. ${ }^{189}$ VitaValley is een zorginnovatienetwerk dat op dat moment als doel heeft om zorginnovaties te initiëren en te versnellen door samenwerking.

In de bespreking vertelt Florijn waar het volgens hem bij PAZIO om zou moeten gaan en hoe een dergelijk project aangepakt zou moeten worden. In plaats van te beginnen bij de belangen van de partners zoals bij de PVZ voorstellen gebeurde, stuurt hij erop aan om opnieuw te gaan denken vanuit de ambities en idealen die de basis voor PAZIO vormen. Voor Florijn is het 'belangrijk om duidelijk te maken welke ambitie we hebben, welke soorten diensten we willen aanbieden aan de respectievelijke gebruikers en welke relaties we aan willen gaan. ${ }^{190}$ Zowel in de doelstelling als in de realisatie van PAZIO staat de patiënt centraal:

'Een belangrijk doel is om de patiënt beter van informatie te voorzien. Florijn merkt op dat bij veel soortgelijke projecten geldt

189 Aanwezig zijn: Florijn (directeur VitaValley), A. Dekker (manager Mediportaal), Knoop (consultant), Rietveld (consultant), Witte (staflid RvB UMCU), Van Damme (dir. LRJG). Afgemeld hebben zich: Torenbeek (VHS) en Veen (UMCU). Van der Tang (CEO VHS) sluit later aan. Dekker, Verslag bespreking PAZIO 9 oktober 2007. Tekstdocument, 9 oktober 2007.

190 Dekker, Verslag bespreking PAZI0 9 oktober 2007. Tekstdocument, 9 oktober 2007, 1-2. 
dat het project mislukt na een geslaagde pilot. De belangrijkste oorzaak is vaak de focus op de techniek, simpel gezegd: technische oplossing zoekt probleem ... Daarom moet je het andersom aanpakken: Als je innovatief wil zijn, moet je de klant (de patiënt) als opdrachtgever centraal stellen en niet praten maar doen. Dat betekent zaken vanuit de patiënt opnieuw bedenken en inrichten.' ${ }^{191}$

De patiënt centraal stellen is voor Florijn niet alleen een doel, maar ook een voorwaarde om tot geslaagde innovatie te komen. Hij lijkt niet te geloven in techniek als oplossing op zichzelf, maar alleen in relatie tot haar gebruikers. Het ideaal van de patiënt centraal gaat hier hand in hand met het geloof in innovatie. Florijn zet de idealen kort en krachtig uiteen. Van Damme, directeur LRJG, versterkt deze boodschap door de inbreng van aanlokkelijke beelden van ontwikkelingen elders.

'Hij is in de VS geweest bij Kaiser Permanente. Wat daarbij geweldig frappeerde was dat de klant zijn eigen dossier kan inzien. Hij kan zijn dokter mailen en krijgt dan binnen 48 uur antwoord. Verder krijgt de patiënt een sms vlak voor zijn afspraak met een reminder van de zaken die hij mee moet nemen. Uit eerste ervaringen blijkt dat het werken met dit systeem in eerste instantie veel werk kost, maar dat het in tweede instantie veel tijd gaat opleveren. Het hele systeem wordt ontlast. ${ }^{\prime 192}$

Dit zou ook hier haalbaar moeten zijn. Van Damme ondersteunt de haalbaarheid doordat hij PAZIO in een eenvoudig beeld vangt. 'PAZIO is naar zijn mening [...] een aantrekkelijke stekkerdoos, waar andere a anbieders hun aanbod aan kunnen koppelen.' ${ }^{\prime 93}$ Het beeld van een 'aantrekkelijke stekkerdoos' blijft hangen bij de deelnemers en zal bij verschillende gelegenheden worden gebruikt in het vervolg van het project. Na alle reflectie doet Van Damme een oproep tot actie:

'Wat gaan we nu doen? We praten nu een jaar en we hebben nog niets gedaan. Er was een behoefte om snel iets te gaan realiseren. Er lag iets op tafel vanuit de artsen: beveiligd e-mail-contact met patiënt. Liefst ook z.s.m. de klant in staat te stellen om grip te krijgen op zijn eigen procesgang, m.a.w. zelf afspraken 
maken, na een bezoek de detailinformatie nog even nazien met toegespitste informatie, folders, patiëntenbrieven etc. uitvinden. We moeten nu doorpakken, er is nu momentum. Bovendien zijn we straks misschien te laat.' ${ }^{194}$

Afgesproken wordt dat er binnen een maand een 'overstijgend projectplan' wordt geschreven. De projectleider A. Dekker neemt daartoe het initiatief.

\section{Het toekomstmotief}

In vervolg op de bijeenkomst schrijven Torenbeek en A. Dekker een Programmaopzet PAZIO. ${ }^{195}$ Het is een omvangrijk document voor intern gebruik, waarin kort en krachtig het doel van het PAZIO-programma wordt weergegeven: duidelijkheid krijgen over 'de wenselijkheid en haalbaarheid van PAZIO als Landelijk Gezondheidsportaal en welke zakelijke opzet daar precies voor nodig is'; aantonen 'dat PAZIO een realiseerbaar platform biedt voor allerlei onlinezorgdiensten' en de realisatie van een 'Proof of Concept (PoC)' ${ }^{196}$ bij de Leidsche Rijn Julius Gezondheidscentra. ${ }^{197}$

De ambities in de programmaopzet reiken verder dan de doelen van het programma zelf. Er wordt al verder gekeken naar een verder liggende toekomst.

'Alles werkt dus toe naar de besluitvorming over het vervolgproject na de PoC. Dit besluit wordt genomen door het nieuw te vormen consortium en is daarmee geen resultaat van de pilot zelf, maar de opstap of kick-off voor de staande organisatie 'Newco' 198 die hieruit volgt.' ${ }^{199}$

Daarvoor moet het programma de volgende zaken opleveren:

'Een consortium met breed maatschappelijk draagvlak dat bereid is PAZIO verder uit te rollen in Nederland. Deze bereidheid is vastgelegd in bindende convenanten;

Een sluitende financiering voor het vervolgproject dat zich richt op de verdere uitrol van PAZIO;

194 Dekker, Verslag bespreking PAZIO 9 oktober 2007. Tekstdocument, 9 oktober 2007, 2.

195 Dekker en Torenbeek. Programmaopzet PAZIO. Tekstdocument, 27 november 2007.

196 PoC staat voor Proof of Concept, een eerste test van het concept in de praktijk

197 Dekker en Torenbeek. Programmaopzet PAZIO. Tekstdocument, 27 november 2007.

198 NewCo staat voor New Company, een nieuw op te richten bedrijf

199 Dekker en Torenbeek. Programmaopzet PAZIO. Tekstdocument, 27 november 2007, 10. 
Een volledig uitgewerkt plan voor dit vervolgproject, waarmee direct na afronding van de pilot kan worden gestart.' ${ }^{200}$

Ook de behoefte aan PAZIO en in het verlengde daarvan haar legitimatie liggen in de toekomst.

'Patiënten worden actieve en bewuste consumenten, die niet alleen met ziekte bezig zijn maar ook met gezond blijven. Overal ontstaan goed bedoelde initiatieven om 'de patiënt centraal' te zetten. Het zal blijken niet genoeg te zijn, omdat ze leveranciers-georiënteerd zijn. De Nederlandse burger heeft behoefte gekregen aan meer regie. Aan kwalitatieve ondersteuning en dienstverlening op het gebied van gezondheid en ziekte ... Kortom: een Landelijk Gezondheidsportaal getiteld PAZIO.' ${ }^{201}$

Hier wordt een voorschot op een onafwendbare toekomst genomen. In die toekomst krijgt de zorgontvanger krijgt drie verschillende rollen toebedeeld: die van patiënt, consument en burger. Patiënten worden actieve en bewuste consumenten, die als Nederlandse burger in die toekomst ook behoefte gekregen hebben aan meer regie. Omdat alle goedbedoelde initiatieven niet genoeg zullen zijn, kan alleen een landelijk gezondheidsportaal getiteld PAZIO ons nog redden.

Opvallend is dat de behoefte en problemen van de toekomst beschreven worden als legitimatie voor PAZIO. PAZIO zelf wordt echter niet beschreven als een in de toekomst te realiseren product. PAZIO en haar functionaliteiten worden beschreven in de tegenwoordige tijd, waardoor het lijkt alsof PAZIO er al is. We lijken ons geen zorgen te hoeven maken over de realisatie of realiseerbaarheid van PAZIO. PAZIO is een rots waarop de toekomst, met al haar behoeften en problemen, kan bouwen. De toekomst is een belangrijk middel om PAZIO aan te kunnen kondigen als oplossing. Naast idealen en ambities is de projectie van de oplossing PAZIO op de toekomst onderdeel van de constructie van het geloof in PAZIO. We zien er nu nog niets van, maar er wordt aangekondigd dat de verlossing nabij is.

\section{'Patiënt centraal' als vooronderstelling, regie als behoefte.}

PAZIO wordt niet gepresenteerd als het redmiddel om de patiënt centraal te stellen. In de programmaopzet wordt voorondersteld dat de patiënt sowieso centraal komt te staan in de zorg. Het is een vooronder- 
stelling dat patiënten zelfbewuste, daadkrachtige, autonome mensen worden op de zorgmarkt.

'Het probleem van (de toekomst van) de gezondheidszorg is in de kern: een snel toenemende en veranderende vraag bij een krimpend aanbod en leveranciers die niet bewegen willen. Een nieuwe en integrale benadering is nodig. En daarin onderscheidt PAZIO (de Patiënt Afhankelijke ${ }^{202}$ ZorgInformatie Omgeving) zich: De patiënt komt niet alleen centraal te staan, maar krijgt ook de regie. PAZIO biedt één online omgeving en infrastructuur waardoor ICT in plaats van disabler een enabler is geworden.' ${ }^{203}$

Het onderscheid tussen 'de patiënt centraal stellen' en 'de patiënt de regie geven' helpt om te beargumenteren dat er een nieuwe behoefte zal ontstaan en dat PAZIO invulling kan geven aan die behoefte. De behoefte aan PAZIO ontstaat door de ontwikkeling van een zorgomgeving waarin de patiënt centraal staat. De meerwaarde van PAZIO is erin gelegen dat ze anders dan de overige ICT-oplossingen een enabler kan zijn voor een regierol van de patiënt.

\section{Wat PAZIO vermag en verwacht}

PAZIO belooft meer te doen dan de consument ondersteunen in zijn regierol. PAZIO biedt de patiënt nieuwe mogelijkheden, 'deze leiden naar verwachting tot kwaliteitsverbetering van de zorg en betere preventie, zodat de patiënt/cliënt langer gezond thuis kan functioneren. De ambitie van PAZIO is om hét nationale gezondheidsportaal te zijn!"204

PAZIO zorgt naast regie voor de patiënt ook voor kwaliteitsverbetering van de zorg, betere preventie, langdurige gezondheid en betrouwbare informatie voor de patiënt. Gezondheid, zorg en zelfredzaamheid worden in de PAZIO stukken relatief weinig expliciet genoemd. Dit zijn de vanzelfsprekende idealen die, net als vooruitgang en innovatie, op de achtergrond richtinggevend zijn voor het project. Daarnaast wordt in de programmaopzet ook een geloof in informatie en communicatie zichtbaar. Dat geloof in informatie en communicatie brengt impliciet verwachtingen van patiënten met zich mee.

202 Het acronym PAZIO staat in de regel voor PAtiëntgeoriënteerde ZorgInformatie Omgeving, de beschrijving als

Patiënt Afhankelijke ZorgInformatie Omgeving, mag als een -interessante- verschrijving beschouwd worden. In de voorgaande alinea werd PAZIO als resultaat van de patiënten emancipatie beschreven. In de regel wordt ze echter gepresenteerd als voorwaarde of enabler daarvan. 
Patiënten hebben volgens de programmaopzet een informatie- en communicatieprobleem. Daardoor zijn ze niet in staat om actieve en bewuste consumenten te worden op de zorgmarkt en daar de regie te nemen. Patiënten hebben onvoldoende beschikking over informatie over ziekte en gezondheid, over zorgverleners en kunnen het eigen dossier niet inzien, laat staan dat ze die informatie zelf kunnen verzamelen of delen. Deze probleemstelling legt de basis voor een ICT-oplossing, of concreter, voor PAZIO.

'De patiënt/cliënt als spil in de keten is het uitgangspunt van PAZIO.... Patiënten/cliënten die online communiceren met zorgverleners, afspraken met zorgverleners plannen/inzien en zelf relevante informatie genereren (zelfmonitoring) zijn mogelijkheden die PAZIO biedt.' ${ }^{205}$

PAZIO faciliteert online communicatie en informatie voor consumenten op de zorgmarkt en belooft daarmee eenvoudige regie en verlengde gezondheid voor diezelfde consumenten. Het vermogen van diezelfde patiënt om die informatie te verwerken en op basis daarvan actief en bewust te handelen, wordt in de beschrijving van de programmaopzet buiten beschouwing gelaten. Kennis is hier een oplossing in plaats van een probleem. Mensen zijn echter niet altijd in staat om met kennis om te gaan en er hun voordeel mee te doen. ${ }^{206}$ Het onderscheid tussen informatie tot je beschikking hebben, informatie kunnen verwerken en begrijpen, deze omzetten in kennis en op basis van kennis in de praktijk kunnen handelen (met alle machten en krachten die daar spelen) wordt niet gemaakt.

De informatieve en communicatieve meerwaarde en mogelijkheden van PAZIO brengen voor de patiënt/consument ook een onuitgesproken patiëntenmoraal mee. Van hen wordt verwacht dat ze kunnen lezen, zich willen en kunnen verdiepen in medische informatie, actief bezig zijn met de eigen gezondheid en de gezondheidszorg om hen heen regisseren. Gezondheid of ziekte zijn niet langer een gegeven van het leven, lot of God, ze vallen onder de eigen regie van de consument. Ziekte moet voorkomen of behandeld worden, gezondheid moet gemanaged worden. Zelfredzaamheid is naast een ideaal ook een dogma. Mensen worden geacht zelfredzaam te (willen) zijn en het wordt vanzelfsprekend geacht dat ze daarin tijd, geld en energie steken. Dat is juist voor patiënten niet altijd eenvoudig.

205 Dekker en Torenbeek. Programmaopzet PAZIO. Tekstdocument, 27 november 2007, 4. 


\section{Projectmanagement}

De uitwerking van het projectmanagement omvat het grootste deel van de programmaopzet. In de hoofdstukken business case, organisatiestructuur, projectplanning, kosten, communicatie, beheersingsmechanismes en risicomanagement wordt beschreven hoe het PAZIO-project wordt georganiseerd, gemanaged en hoe om wordt gegaan met risico's en afwijkingen. Het abstracte idee en ideaal PAZIO, wordt hier hanteerbaar en maakbaar beschreven. In woord en beeld (zie fig. 3.5) wordt er structuur gegeven aan het project door mensen, taken en tijden te onderscheiden en aan elkaar te koppelen. Dit geeft de indruk dat de projectleiders grip hebben op het project en weten hoe ze het ontwikkelproces moeten vormgeven.

Door de inhoudelijke structuur en heldere beschrijving van het projectmanagement, ontstaat er vertrouwen in de maakbaarheid van het project PAZIO. Daarbij put de programmaopzet uit erkend technisch rationele methoden zoals beschreven in de (project)management literatuur. De auteurs laten zien dat ze bekend zijn met de literatuur over projectmanagement en verwijzen ook expliciet naar dergelijke erkende projectmanagement instrumenten. 'Voor de communicatie en rapportage binnen het programma PAZIO heeft het programmamanagement gekozen voor de systematiek en sjablonen van PRINCE2.'208

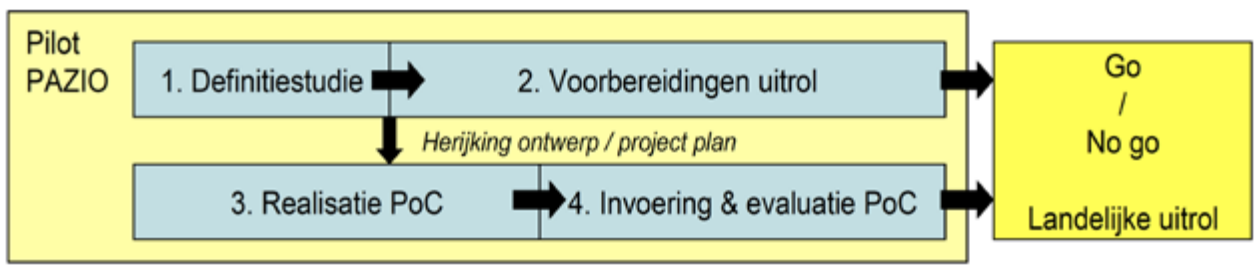

FIGUUR 3.5 Structuur en planning van het project PAZI0. ${ }^{207}$

207 Dekker en Torenbeek. Programmaopzet PAZIO. Tekstdocument, 27 november 2007, 13.

208 PRINCE2 is een acroniem van Projects in Controlled Environments, version 2. Deze methode is gericht op het management, de besturing en de organisatie van een project. 


\section{Performatieve effect van de programmaopzet}

De programmaopzet is een belangrijk en effectief document in de ontwikkelingsgeschiedenis van PAZIO. De programmaopzet biedt de betrokkenen bij PAZIO en gedeeld kader met drijfveren, ambities en grondmotieven. Het realiseren of behouden van gezondheid van mensen is een belangrijke drijfveer. Als die gezondheid er niet is, dan is zorg een oplossing. Die zorg moet van hoge kwaliteit zijn en de patiënt moet de regie hebben. Informatie en communicatie zijn de voorwaarden voor het kunnen voeren van de regie. Om te werken aan de realisatie van gezondheid of regie voeren vertrouwt men op wetenschappelijke en technische rationaliteit: evidence based medicine, ICT en rationele projectmanagement tools zijn de middelen om de ambities te realiseren.

De programmaopzet creëert samenhang en vertrouwen in de toekomst van het project PAZIO, bevestigt wat er gebeurd is en legt dat verleden vast in afspraken. Het beschrijft de rollen en verhoudingen tussen de deelnemers. Een belangrijk effect van de programmaopzet is dat de lezers vertrouwen krijgen in het product PAZIO, in het project en de projectleiding. De programmaopzet zorgt voor geloof in het project bij de lezers en stuurgroepleden, maar waarschijnlijk ook voor zelfvertrouwen bij de auteurs en het programmamanagement zelf.

De stuurgroepleden hebben bij de bespreking slechts detail-opmerkingen bij de programmaopzet. Klaarblijkelijk deelt men de uitgangspunten en is het vertrouwen in het beschreven idee PAZIO en de overall programmaopzet groot genoeg om te participeren. Dit geloof en vertrouwen wordt de volgende vergadering bekrachtigd en gejuridiseerd door het ondertekenen van het convenant en de programmaopzet.

\subsubsection{DEFINITIESTUDIE}

$\mathrm{Na}$ de goedkeuring van de programmaopzet werkt het projectmanagement aan een definitiestudie voor PAZIO. ${ }^{209}$ De definitiestudie is een intern document waarin het product PAZIO en de ambities en idealen praktisch worden uitgewerkt. In de definitiestudie wordt beschreven wat de beoogde doelen, functionaliteit, architectuur, organisatie, marktanalyse en business case van PAZIO zijn. Naast expliciete ambities, worden in de definitiestudie ook impliciete vooronderstellingen en overtuigingen rond PAZIO zichtbaar. Ideeën over zorg, rollen en taken van patiënten en zorgverleners, gezondheid, ICT en vooruitgang en kwaliteit worden zichtbaar doordat ze vertaald worden in het product PAZIO. 
De definitiestudie is opgesteld door het business team PAZIO o.l.v. De Lange. De Lange is op dat moment zelfstandig consultant en oudcollega van Florijn bij Ernst \& Young. Hij wordt hiervoor ingehuurd door VitaValley. Het team dat met hem aan de definitiestudie meewerkt is breed. Als auteurs worden genoemd Pijl, De Lange, A. Dekker en Torenbeek. Daarnaast zijn er door verschillende medewerkers bijlagen geschreven, die de basis vormen voor verschillende hoofdstukken van de definitiestudie. ${ }^{210}$ De definitiestudie is gedateerd 16 juli 2008 en omvat 45 pagina's. Op 23 juli van dat jaar wordt het stuk besproken in de stuurgroepvergadering. ${ }^{211}$ In hun voorwoord vertellen de auteurs dat PAZIO al twee jaar in hun hoofd bestaat en hun

'fantavisie moest concreet worden... De eerste echte mijlpaal werd bereikt, toen we als partners de aftrap gaven in de zomer van 2007. Nu is een volgend belangrijk moment om te beslissen aangebroken. In dit document wordt wat ons aangaat de tweede echte mijlpaal bereikt: het biedt $u$ een uitgebreid definitiestudie van PAZIO.'212

De stuurgroep wordt op basis van de definitiestudie gevraagd het licht op groen zetten voor de volgende stappen:

het realiseren van het PAZIO-portaal;

De pilot in Leidsche Rijn;

De nadere invulling van de benodigde onderliggende

financiering; ${ }^{213}$

210 De bijlage en hun auteurs zijn:

- Bijlage Definitiestudie PAZIO: Architectuur; door het business team, m.n. De Jong

- Bijlage Definitiestudie PAZIO: Functionaliteit; door het business team, m.n. De Lange

- Bijlage Definitiestudie: Demografische analyse en marktanalyse PAZIO; door het business team, m.n. Neutel.

211 Redekker, Verslag PAZIO stuurgroepvergadering 23 juni 2008. Tekstdocument, 23 juni 2008.

212 Business Team PAZIO, Definitiestudie PAZIO. Tekstdocument, 16 juni 2008, 3.

213 Business Team PAZIO, Definitiestudie PAZIO. Tekstdocument, 16 juni 2008, 3 


\section{Idealen}

De definitiestudie opent met een situatieschets van de zorg die vrijwel letterlijk overgenomen is uit de hiervoor besproken programmaopzet. Er is een subtiel verschil. De conclusie is hier niet dat de burger behoefte heeft aan meer regie, maar dat er behoefte is aan 'aan verbeterde communicatie, procesoptimalisatie en informatie-uitwisseling met de burger en in de lijn. ${ }^{214}$ Daarmee staat de burger niet vanzelfsprekend centraal, ze is in plaats van regisserend-subject nu object in de processen. De mogelijkheden die PAZIO biedt (zoals online communicatie met zorgverleners) moeten bijdragen aan kwaliteitsverbetering van de zorg, zoals ook in de programmaopzet verwoord. Daarnaast heeft PAZIO de ongewijzigde ambitie om het nationale gezondheidsportaal te zijn! ${ }^{215}$ De definitiestudie bouwt voort op de programmaopzet maar heeft een eigen karakter.

Het doel van de definitiestudie is het uitwerken van een Programma van Eisen (PvE), een bijbehorend businessmodel met business case. Er is daarbij alle vertrouwen in de beoogde realisatie en toekomst van PAZIO.

'Het is mogelijk en wenselijk om PAZIO $\mathbf{N U}^{216}$ te realiseren. Hiertoe worden in eerste instantie succesvolle bestaande toepassingen geïntegreerd met uniforme, gezamenlijke ID en login. De bestaande diensten eConsult, Patiëntenzelfmanagement van Vital voor Diabetes en Research Online zijn succesvol. In de overkoepelende portaalapplicatie van PAZIO worden deze diensten logisch ondergebracht, zodat de patiënt één ingang heeft, maakt opschaling realiseerbaar. Na een succesvolle pilot in de vinexlocatie Leidsche Rijn is het concept in heel Nederland toepasbaar en kunnen meerdere succesvolle diensten m.b.v. dit platform opschalen. ${ }^{217}$ Als alles volgens de opgenomen planning loopt zal PAZIO in 2010 het nationale gezondheidsportaal zijn. ${ }^{218}$ 


\section{Uitgangspunten}

In de definitiestudie worden hiervoor veertien uitgangspunten meegegeven:219 Het eerste uitgangspunt grondvest PAZIO, het is het grondmotief: 'PAZIO is primair een portaal voor de zorgconsument en zijn omgeving. ${ }^{220}$ Dat is voor de schrijvers meer dan een vooronderstelling of technisch uitgangspunt. Hieruit spreekt geloof in de waarde van de patiënt en schetsen de schrijvers een beeld van goede zorg: daarin staat de patiënt centraal. De sympathie van de schrijvers ligt bij wat ze hier noemen de zorgconsument. Het tweede uitgangspunt heeft een organiserend karakter. 'De 'toegang' tot PAZIO verloopt voornamelijk via de sites van de zorgverleners, dus niet rechtstreeks (de functionaliteit moet uitgaan van de bestaande behandelrelatie).' ${ }^{221}$ De zorgverlener wordt gezien als de poortwachter voor de toegang tot PAZIO.

De uitgangspunten 3 t/m 14 zijn technisch van aard. Het zijn technische en functionele mededelingen over sites, inloggen, generiek modules, multilevel authentication en standaarden. Met die technische termen wordt een technische grondpositie gecreëerd op basis waarvan de andere ambities en idealen gerealiseerd moeten gaan worden. Het geloof in het oplossend vermogen van techniek is groot. De uitdaging ligt erin de technische mogelijkheden te koppelen aan de grondmotieven.

219 '1) PAZIO is primair een portaal voor de zorgconsument en zijn omgeving; 2) De 'toegang' tot PAZIO verloopt voornamelijk via de sites van de zorgverleners, dus niet rechtstreeks (de functionaliteit moet uitgaan van de bestaande behandelrelatie). Voor zorgconsumenten die een directe ingang prefereren, wordt ook een zelfstandig PAZIO-portaal ontwikkeld; 3) De look \& feel van PAZIO volgt de site waar de bezoeker vandaan komt; 4) PAZIO omvat ook de mogelijkheid om een volwaardige site te realiseren t.b.v. de zorgverlener (white label); 5) De gebruiker hoeft maar één keer in te loggen om van alle beveiligde onderdelen van PAZIO-gebruik te maken; 6) PAZIO kan content / functionaliteiten presenteren aan de gebruiker die - ook in fysiek opzicht - door derden worden aangeboden; 7) De leverancier van de content/functionaliteit blijft verantwoordelijk voor zijn content/functionaliteit; 8) Per gebruiker kan bepaald worden welke modules in PAZIO worden getoond; 9) De zorgverlener zelf kan kiezen welke modules/functionaliteiten hij beschikbaar stelt aan zijn zorgconsumenten; 10) Een vorm van 'multilevel authentication' is wenselijk, zodat de gebruiker alleen aanvullend bewijs over de eigen identiteit hoeft te leveren als dat echt nodig is; 11) Voor bepaalde functionaliteiten verdient het de voorkeur dat iedere deelnemende partij zijn content integreert binnen één generieke module, omdat de gebruiker gebaat is bij integratie van de content. Een voorbeeld hiervan is agendafunctionaliteit. 12) Binnen PAZIO is ruimte voor generieke modules met voor de gebruiker interessante functionaliteit, die niet rechtstreeks aan één leverancier gebonden is. Hierbij valt bijvoorbeeld te denken aan NHG-standaarden, maar ook aan zelftests; 13) PAZIO dient ook toegankelijk te zijn voor slechtzienden en blinden; 14) Waar van toepassing wordt gebruik gemaakt van de iure of de facto standaarden. Voorbeelden zijn: de uitwisseling van berichten tussen onderdelen van het platform (bijv. door het toepassen van webservices en HL7). 
Een belangrijke basis voor de definitiestudie zijn een literatuuronderzoek en een veldonderzoek waar in de definitiestudie melding van wordt gemaakt. Het onderzoek concentreert zich op drie begrippen: 'patient empowerment', 'e-health' en 'ontwikkelingen in de gezondheidszorg'.222 $\mathrm{De}$ resultaten van dit literatuuronderzoek worden niet expliciet genoemd, maar wel wordt aangegeven dat ze verwerkt in de ICT-architectuur, de projectorganisatie en het businessmodel. Dat geldt ook voor de resultaten van 'een aantal groepssessies met de projectgroep waarin onder andere ook een huisarts en een fysiotherapeut waren vertegenwoordigd.' Er wordt geen melding gemaakt van de participatie van patiënten of patiëntenvereniging in die projectgroep. Ook elders in de projectdocumenten zijn geen aanwijzingen gevonden voor input door patiënten of patiëntenverenigingen. In de definitiestudie wordt de term patiëntempowerment verder niet gebruikt en wordt de rol van de patiënt in het zorgproces niet expliciet beschreven. Om toch zicht te krijgen op de ideeën over de rol van de patiënt, ontwikkelingen in de zorg en e-health moeten we dus uitzoeken hoe deze vertaald worden in de verschillende onderdelen van de definitiestudie.

Eén van die onderdelen is het hier geïntroduceerde logo voor PAZIO (zie fig. 3.6). De auteurs van de definitiestudie schrijven in hun voorwoord: 'PAZIO bestaat al twee jaar, namelijk in onze gedachten. De werknaam van het eerste uur staat nog overeind: PAZIO. En PAZIO heeft nu ook een logo.' ${ }^{223}$ 
Interpretaties van symbolische afbeeldingen, zoals logo's zijn altijd te bevragen, maar het logo van PAZIO lijkt niet bijzonder dubbelzinnig. Het logo heeft een kern (de 'O' van PAZIO) die golven uitzend naar en/ of ontvangt van de omgeving. In lijn met haar grondmotief 'de patiënt centraal', weerspiegelt die kern de patiënt die daarbij ondersteund wordt door PAZIO. De patiënt staat centraal en de zorg is rond de patiënt georganiseerd. De golven staan voor het zenden naar en ontvangen van informatie door de patiënt en de communicatie tussen de patiënt en zijn zorgverleners. Deze interpretatie van het logo sluit aan op de ambities, grondmotieven en naam van een Patiënt georiënteerde Zorg Informatie Omgeving.

Naast het logo is er nog een andere afbeelding die PAZIO in de definitiestudie verbeeld: de architectuurschets (zie fig. 3.7). PAZIO wordt in de architectuur afgebeeld als een box. In die box zitten weer andere boxen, het is een massief geheel met duidelijke grenzen. Die box is volledig gevuld met functies, applicaties, beheerrollen en datamanagement. In de architectuurschets omvat PAZIO alle functionaliteit en data. 'Binnen PAZIO word bestaande functionaliteit van diverse leveranciers geïntegreerd. Het is dus niet de bedoeling om tot één integrale applicatie te komen.' ${ }^{224}$

De box staat stevig op zichzelf met een paar dunne verbindingen naar andere veel kleiner afgebeelde systemen en hardware vormen: PAZIO staat hier centraal. De plek van zorgconsument en zorgverlener zijn in deze architectuurplaat niet aangegeven; het draait hier om de technische oplossing. Zij zal op haar beurt de patiënt centraal stellen in het zorgproces, zo is de belofte en overtuiging. De belofte van PAZIO om patiënt-georiënteerd te zijn, komt in deze architectuurschets niet tot uitdrukking. Wat de positie van de patiënt betreft is de architectuurschets een black box. 


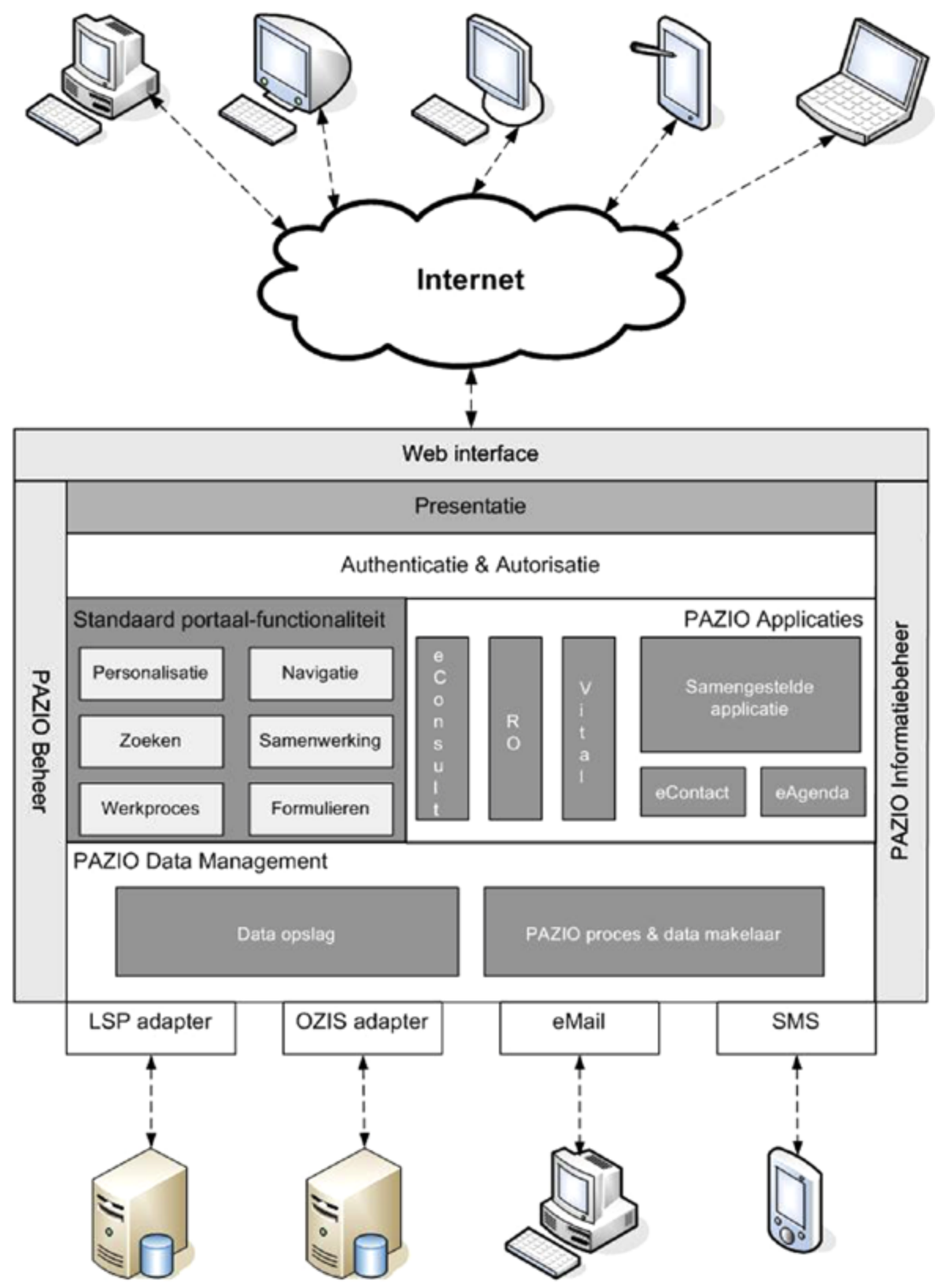

FIGUUR 3.7 Architectuurschets PAZI0.225 


\section{Functionaliteit}

De toelichtende tekst bij de architectuurtekening laat wat meer licht schijnen op de verbinding tussen PAZIO en patiënt.

'Via elk mogelijk apparaat met een internetaansluiting heeft de gebruiker (zorgconsument of zorgverlener) toegang tot PAZIO. Het portaal biedt een gepersonaliseerde webinterface, waardoor de gebruiker snel en eenvoudig toegang heeft tot de informatie die voor die gebruiker relevant is. De gebruiker hoeft maar eenmaal in te loggen om toegang te krijgen tot alle informatie en functionaliteit waar de gebruiker voor geautoriseerd is. PAZIO biedt de gebruiker een geïntegreerde omgeving met de gewenste functionaliteit:

Informatie over ziekte en gezondheid;

Informatie over zorgverleners;

De mogelijkheid zich op eHealth-diensten te abonneren;

De mogelijkheid met de eigen zorgverleners te communiceren en advies in te winnen;

Inzicht in de eigen dossiergegevens;

De mogelijkheid het eigen dossier beschikbaar te stellen aan zorgverleners;

De mogelijkheid eigen zorgprocessen te initiëren en regisseren. Daarnaast is het mogelijk in het kader van het zorgproces te communiceren via e-mail, SMS en andere standaard communicatiemogelijkheden.' ${ }^{226}$

\section{Toegevoegde waarde}

De functionaliteiten beschrijven wat PAZIO moet gaan kunnen. De impact daarvan wordt veel verder in de definitiestudie bij de presentatie van de businesscase gepresenteerd.

'Met PAZIO wordt de volgende toegevoegde waarde gecreëerd:

Patiënt empowerment door informatie op maat;

Stimulering van preventie en patiëntzelfmanagement;

Verbeterde begeleiding van zorgconsument;

Hogere kwaliteit van zorg en verbeterde patiëntveiligheid door integratie en aanbieden evidence based behandelmethoden -> draagt bij aan verbeterde diagnostiek;

Managementinformatie, waardoor onder meer betere preventie mogelijk wordt; 
Ketenzorg (onder meer door de inzet van de software van VitalHealth) en in het verlengde daarvan netwerkzorg;

Toegankelijkheid zorg (7×24, makkelijk te vinden, onafhankelijk van plaats, één keer inloggen);

Eén ingang (geldt zowel voor patiënt, als voor zorgprofessional); Groter bereik voor zorgprofessional door onafhankelijkheid van plaats;

Minder onnodige consults door decision aids;

Minder fysieke bezoeken door e-consults en zelfhulp;

Tijdwinst voor de patiënt (hoeft minder vaak naar de professional toe), maar ook voor de zorgprofessional (kunnen elkaar sneller vinden);

Verbeterde communicatie tussen zorgprofessionals;

Minder dubbel invoeren van dezelfde gegevens;

Hogere klanttevredenheid (moeilijk om te zetten in geld),. ${ }^{227}$

De impact van PAZIO zoals hier geschetst, is indrukwekkend. Dat maakt nieuwsgierig naar de vraag hoe PAZIO die impact gaat realiseren. Hoe gaat wat de gebruikers met PAZIO kunnen, leiden tot effecten op de positie van de patiënt en de zorg? Die verbinding tussen doelen en middelen wordt in de definitiestudie niet uitgewerkt of toegelicht. De realisatie van de idealen vraagt om vertrouwen en geloof. Niet alleen geloof in die idealen maar ook in de techniek. De verbinding tussen de idealen en de techniek, tussen logo en architectuurschets moet in de praktijk gerealiseerd gaan worden.

\section{Keuzes}

De hierboven genoemde functionaliteiten van PAZIO slechts mogelijkheden: ze zijn nog niet gerealiseerd en ze zijn ook niet zomaar te realiseren. De schrijvers van de definitiestudie begrijpen dat ook niet alles tegelijkertijd gerealiseerd kan worden. Er moeten keuzes gemaakt worden, bijvoorbeeld over de als eerste te integreren functionaliteiten. Wat daarbij meteen opgemerkt wordt is dat

'PAZIO primair [is] gericht op de zorgconsument. Naast op de zorgconsument gericht evidence-based informatie en functionaliteiten kan PAZIO desgewenst ook andere doelgroepen bedienen, zoals: zorgconsument, lotgenoten, patiëntomgeving, mantelzorgers, belangenorganisaties, zorgprofessionals, zorginstellingen, zorgverzekeraars, overheid, academici, 
farmaceuten. De overige doelgroepen zijn vooral te kenschetsen als belanghebbenden. Willen deze belanghebbenden het gebruik van PAZIO onderschrijven, dan dienen ook zij beter te worden van PAZIO (what's in it for me?).' ${ }^{228}$

PAZIO is plots niet langer alleen patiënt-georiënteerd, ze kan ook de belangen van andere doelgroepen bedienen. Ze is wel primair gericht op de zorgconsument, maar sluit daarmee andere belanghebbende doelgroepen allerminst uit.

In de definitiestudie worden geen scherpe criteria gegeven om keuzes te maken over de ontwikkeling van PAZIO en waar op welk moment aan gewerkt moet worden. Er is een weinig specifieke lijst met algemene termen als: must haves, should haves, kosten, onderscheidend, doorlooptijd. Ze is niet specifiek voor de zorg, patiënt emancipatie of PAZIO en ze bevat geen inhoudelijke criteria over zaken als kwaliteit van zorg. Daardoor komen zaken als het primaire proces of het centraal stellen van de patiënt niet vanzelfsprekend tot hun recht.

Hoe de ambities en idealen rond PAZIO, zoals de gerichtheid op de patiënt, vertaald worden in de criteria is onduidelijk. De criteria geven weinig richting aan de ambities en idealen van PAZIO, in het keuzeproces verdwijnen ze ongemerkt uit zicht waardoor belangen en randvoorwaardelijke overwegingen een groter stempel kunnen drukken. Het gebruik en de weging van de criteria bij de keuze voor functionaliteiten wordt in de definitiestudie en de bijlage over functionaliteitselectie ${ }^{229}$ niet beschreven. Het resultaat daarvan is echter helder:

$\begin{array}{ll}\text { 'eind 2008: } & \text { informatie, eConsult, research-online, patiënt } \\ & \text { zelfmanagement diabetes; } \\ \text { medio 2009: } & \text { realisatie must haves; } \\ \text { eind 2009: } & \text { realisatie should haves; } \\ \text { 2010: } & \text { in de loop van 2009 dient nader bepaalt te } \\ & \text { worden welke functionaliteit in } \\ & \text { 2010 moet worden gerealiseerd. Behoefte van } \\ & \text { zorgconsumenten, draagvlak } \\ & \text { onder professionals en verwachte inkomsten } \\ & \text { spelen een belangrijke rol in de nadere } \\ & \text { afweging.' }\end{array}$


Er worden drie tools benoemd die eind 2008 geïnstalleerd moeten zijn: eConsult, research-online, patiënt zelfmanagement diabetes. Deze komen rechtstreeks uit de stal van de partners. eConsult is een product van Mediportaal; patiënt zelfmanagement diabetes van VitalHealth Software en Research Online van UMCU. Research-online is een tool voor onderzoekers om digitaal vragenlijsten af te nemen. Ze heeft geen relatie met de primaire processen in de zorg; hoogstens kan op basis van de data uit research-online daarop in algemene zin gereflecteerd worden. De keuze om research-online prominent in de eerste fase van de PAZIO-ontwikkeling op te nemen sluit niet aan bij de ambities zoals genoemd in de definitiestudie. De patiënt schiet er voorlopig niets mee op en het zorgproces evenmin. De aanleiding voor het UMCU en LRJG om research-online te willen inbedden in PAZIO is goed te begrijpen vanuit de belangen van de onderzoekers. ${ }^{231}$ Die belangen hebben echter feitelijk geen connectie met de geformuleerde ambities van PAZIO.

Het blijkt niet eenvoudig om samen koers te houden en PAZIO patiënt-georiënteerd te blijven ontwikkelen als er daadwerkelijk keuzes gemaakt moeten worden met praktische consequenties. Particuliere belangen overvleugelen gedeelde idealen. Ieder krijgt een deel van het welbegrepen eigenbelang maar dat gaat ten koste van het groter gedeelde ideaal.

\section{Gevestigde orde}

In de definitiestudie ligt een spanning besloten tussen de ambitie naar vernieuwing en aansluiten bij het bestaande. Het eerste uitgangspunt is dat PAZIO is primair gericht op de zorgconsument, het hart van PAZIO ligt bij de patiënt, daarop wil ze zich oriënteren. Het daaropvolgende tweede uitgangspunt luidt: De 'toegang' tot PAZIO verloopt voornamelijk via de sites van de zorgverleners, dus niet rechtstreeks (de functionaliteit moet uitgaan van de bestaande behandelrelatie).' ${ }^{232}$ Dit uitgangspunt legt de nadruk op het belang van de bestaande behandelrelatie en de zorgverlener. ${ }^{233}$ Daarbij is het ook de zorgverlener die kiest welke

231 In Leidsche Rijn voert het Julius Centrum - onderdeel van het UMCU dat onderzoek doet op het gebied van o.a. huisartsgeneeskunde, epidemiologie - het Leidsche Rijn Julius GezondheidsProject (LRGP) uit onder de bevolking. In dat onderzoek speelt het LRJG - het gezondheidscentrum in de nieuwbouwwijk Leidsche Rijn en voor een aanzienlijk deel eigendom van het UMCU - een centrale rol. Via hen wordt contact gelegd met bewoners. Research Online kan in dat onderzoeksproces een waardevolle tool zijn voor de onderzoekers en PAZIO is voor hen daarbij een mooi portaal om patiënten/bewoners te bereiken.

232 Business Team PAZIO, Definitiestudie PAZIO. Tekstdocument, 16 juni 2008, 5.

233 De spanning sluit aan op de spanning tussen vrijheid en beheersing die Dooyeweerd in de hedendaagse cultuur ziet. In de zorg is een spanning zichtbaar tussen de autonomie van de patiënt en de beheersing die ontstaat door een samenspel tussen kennis en autoriteit in de geneeskunde. 
modules/functionaliteiten hij beschikbaar stelt aan zijn zorgconsumenten. PAZIO conformeert zich aan de gevestigde orde in de zorg, waarin de patiënt de zorgconsument is en de zorgverlener de zorgaanbieder. De uitgangspunten zorgen voor een kader waarin de klassieke rolverdeling in de zorg wordt gebruikt, maar daarmee ook wordt versterkt en bevestigd. PAZIO is idealiter een portaal voor de zorgconsument, maar in de praktijk is de zorgverlener nog steeds de spil in het portaal.

In de marktanalyse zien we de bevestiging van de gevestigde orde ook terug. Het verdienmodel via het kanaal van de gezondheidscentra staat prominent bovenaan; deze is het meest uitgewerkt. ${ }^{234}$ Dat primaire verdienmodel van PAZIO is erop gebaseerd dat PAZIO aan de zorgverlener wordt verkocht. De zorgverlener biedt PAZIO vervolgens in haar eigen look-and-feel aan haar patiëntenpopulatie aan. Dat maakt het eerstelijns gezondheidscentrum LRJG daarmee een geschikte launching customer en een geschikte omgeving voor een implementatiepilot.

Dat het portaal zo wordt ingebed in de gevestigde orde is praktisch gezien niet verwonderlijk. PAZIO is immers primair een initiatief van het UMCU en het daaraan gelieerde LRJG; beide zijn zorgaanbieders. Voor hen is zorg verlenen onlosmakelijk verbonden met hun professionele betrokkenheid en regierol. Daarnaast is één van de oorspronkelijke redenen voor het UMCU voor het ontwikkelen van PAZIO de ambitie om de verbondenheid met huisarts en patiënt te verbeteren en zo hun adherentiegebied te versterken en te vergroten. ${ }^{235}$ Op vergelijkbare wijze is klantenbinding een belangrijk motief voor LRJG: hun betrokkenheid is primair gericht op het verbeteren van de service aan patiënten. De zorginformatie-omgeving is dus niet alleen patiënt-georiënteerd, maar ook een tool om diezelfde patiënt te behouden. PAZIO is er bijvoorbeeld dan ook niet op gericht om patiënten te ondersteunen in het vinden en kiezen van een andere zorgverlener. Ze heeft niet de ambitie om voor transparantie en keuzemogelijkheden binnen het zorgaanbod te zorgen, eerder is PAZIO een lock in voor de patiënt met betrekking tot zijn zorgverlener. PAZIO zorgt dat de bestaande behandelrelatie tussen zorgverlener en patiënt ook digitaal wordt bevestigd en versterkt. Voortbouwen op de bestaande behandelrelatie zorgt echter niet vanzelfsprekend voor patiëntenemancipatie, eerder bevestigt ze de gevestigde orde. 


\section{Geloof in patiënt centraal en technologie}

Betekent het commitment aan de gevestigde orde in de zorg dat PAZIO haar idealen en ambities met betrekking tot het centraal stellen van de patiënt in de praktijk loslaat? Is het leven sterker is dan de leer? Niet noodzakelijk. Er is geen reden om te twijfelen aan het geloof van de betrokkenen. Het geloof in een patiënt-georiënteerd portaal is oprecht en stevig. Het komt terug in het logo en in de naam, er wordt over gepraat in het projectteam en de stuurgroepbijeenkomsten en het staat geschreven in vrijwel alle richtinggevende stukken voor het project PAZIO. De overtuiging is dat de patiënt centraal moet komen te staan in de zorg. Dat is goed voor de zorg, voor de patiënt en voor zijn of haar gezondheid.

Verbonden aan de overtuiging van het centraal stellen van de patiënt is de overtuiging dat door het verbeteren van de informatie- en communicatiemogelijkheden van de patiënt, de patiënt vanzelf meer regie kan nemen en een centrale positie in het zorgproces kan innemen. Het verbeteren van de informatie- en communicatiemogelijkheden wordt gezien als een probleem dat met technologie relatief eenvoudig op te lossen is. Kortom: met behulp van ICT kunnen we de patiënt centraal zetten. De ICT kan dat zelfs als verdienmodellen (via de zorgverlener) en functionaliteiten (zoals research-online) dat niet ondersteunen, omdat ze de patiënt niet centraal stellen. Klaarblijkelijk is het geloof in de techniek zo sterk dat de betrokkenen ervan overtuigd zijn dat de techniek op zichzelf kan bijdragen aan het centraal stellen van de patiënt. Het toont een groot geloof in de zelfstandige veranderkracht van de technologie van PAZIO.

Dat geloof kan in stand blijven doordat de vervulling van alle beloftes in de toekomst ligt. Dit zijn slechts de aankondigingen van de verlossing. Die belofte van patiëntgerichtheid en patiënten emancipatie is cultureel breed gedragen; daar kan je met goed fatsoen niet tegen zijn. De realisatie van die belofte wordt gedaan door de inzet van ICT of technologie. Ook dat sluit aan bij een bredere culturele onderstroom in de technologische cultuur. Technologie heeft ziekten verslagen, zorgt voor reserveonderdelen voor ons lichaam en voor robots die ons kunnen opereren. Dat hier de link tussen de belofte om de patiënt centraal te zetten, de functionaliteiten en de techniek nog niet helemaal duidelijk is, doet niet direct af aan de overtuiging van het technologische vermogen. Technologie is zo vaak een black box die we niet begrijpen, maar desondanks werkt en doet wat ze belooft. Waarom zou dat hier anders zijn? Doordat de lijn tussen doelen en middelen, tussen idealen en de realisatie daarvan in praktijk ontbreekt wordt technologie een deus ex machina. 


\subsubsection{PIEKEN IN DE DELTA-PROJECTPLAN}

In 2006 was de subsidieregeling Pieken in de Delta een belangrijke aanleiding om te komen tot de ontwikkeling van plannen voor een PVZ, maar tot een subsidieaanvraag is het destijds niet gekomen. Wel wordt er in 2007 een aanvraag voor het Actieprogramma M\&ICT geschreven. Subsidies worden door de stuurgroep van serieus belang geacht. In de stuurgroep vergadering van 2 oktober 2008 geeft het projectteam een voorzet voor mogelijke subsidiemogelijkheden. (zie tabel 3.1) ${ }^{236}$ In reactie daarop geeft voorzitter Kuilboer aan 'dat het binnenhalen van subsidies een voorwaarde is voor een geslaagde businesscase. De stuurgroep vraagt in dit kader om een overzicht van alle relevante subsidies met sluitingsen toekenningsdata. Een bedrag van EUR 1 a 2 mln moet binnengehaald kunnen worden.' ${ }^{237}$

\begin{tabular}{|c|c|c|}
\hline Prioriteit & Regeling/programma & Planning \\
\hline $1^{\circ}$ instantie & $\begin{array}{l}\text { Innovatiefonds Zorgverzekeraars en } \\
\text { Zorginnovatieplatform }\end{array}$ & Oktober 2008 \\
\hline $2^{\circ}$ instantie & Pieken in de delta & $\begin{array}{l}\text { In oktober } 2008 \text { een verkennend } \\
\text { gesprek voeren }\end{array}$ \\
\hline $3^{\circ}$ instantie & Subsidieregeling WWS-subsidies & $\begin{array}{l}\text { In oktober } 2008 \text { een verkennend } \\
\text { gesprek voeren }\end{array}$ \\
\hline $4^{\circ}$ instantie & $\begin{array}{l}\text { Diverse fondsen: Achmea, VSB, Voorzorg, } \\
\text { CVZ }\end{array}$ & Oktober/november 2008 \\
\hline $5^{e}$ instantie & Innovatie in de care & $\begin{array}{l}\text { Tender najaar, zodra openstelling dit } \\
\text { najaar }\end{array}$ \\
\hline $6^{\circ}$ instantie & Innovatie in de zorg / Zon Mw & $\begin{array}{l}\text { Bij openstelling tender, begin } 2009 \text { (of } \\
\text { zoveel eerder) }\end{array}$ \\
\hline
\end{tabular}

TABEL 3.1 Besproken subsidieprogramma's en regelingen voor PAZIO. ${ }^{238}$

Subsidieverleners hebben echter niet vanzelfsprekend eenzelfde geloof in PAZIO. Uit het stuurgroepverslag van februari 2009 blijkt dat het Innovatiefonds van de Zorgverzekeraars in een brief meldt 'dat het PAZIO-initiatief niet uniek is. De overtuiging [van de stuurgroep] is dat PAZIO wel uniek is en er dus iets misgegaan is met het overbrengen 
van het idee. Dit is een leerpunt voor de toekomst.' ${ }^{239}$ In de stuurgroep vergadering van januari 2009 meldt het programmanagement dat

'bij de ZonMw-subsidie met betrekking tot 'patient empowerment' het advies van ZonMw was om niet in te dienen. De stuurgroep vraagt zich af of dat advies terecht is. Hij pleit ervoor om te overwegen toch in te dienen. Het programmamanagement zal dit in overweging nemen. ${ }^{240}$

Het beeld dat de stuurgroep van het PAZIO-project heeft, sluit niet aan bij het beeld dat de buitenwereld heeft of in ieder geval niet bij het beeld dat de verantwoordelijken bij het ZonMw-programma voor patient empowerment hebben. PAZIO wordt door ZonMw niet als patient empowerment machine gezien, krijgt hiervoor geen subsidie en kan zich daardoor ook minder in die richting ontwikkelen. Er zijn echter andere kansen, die andere ontwikkelingsrichtingen met zich meebrengen.

In 2009 is er opnieuw gelegenheid om subsidieaanvragen in het kader van het Pieken in de Delta programma te doen. Het PAZIO-consortium schrijft daarvoor een aanvraag, die bestaat uit een projectplan, begroting en financieringsplan en steunbetuigingen vanuit onder meer verschillende zorgaanbieders, zorgverzekeraars, beroepsverenigingen en ICT-leveranciers. Opvallend is dat in de lijst van steunbetuigingen en supporters ${ }^{241}$ een patiëntenvereniging of andere vorm van patiëntensteun ontbreekt.

'De regeling Pieken in de Delta had tot doel door middel van het verstrekken van subsidie het ondernemers- en vestigingsklimaat in Nederland te versterken." ${ }^{242}$ Zoals we bij eerdere subsidieaanvragen ook zagen, zorgt een dergelijke doelstelling ervoor dat er een nieuwe interpretatie van PAZIO moet worden opgebouwd. Volgens de aanvraag zal PAZIO 'als een economische motor dienen voor ICT-bedrijven en dienstverleners, die hun kennis, technologie en toepassingen willen inzetten ter ondersteuning van de gezondheidszorg.' Het probleem waar PAZIO de oplossing voor biedt in deze aanvraag is het volgende:

'Momenteel is toegang tot de gezondheidszorg één van de grootse bottlenecks voor de ICT-sector. ... Met PAZIO wordt de ICT-leveranciers en dienstverleners de mogelijkheid geboden

\footnotetext{
239 Witte, Verslag PAZIO-stuurgroepvergadering 26 februari 2009. Tekstdocument, 26 februari 2009, 1.

240 Witte, Verslag PAZIO-stuurgroepvergadering 05 januari 2009. Tekstdocument, 5 januari 2009.

241 Niet alle in het projectplan opgevoerde supporters hebben een steunbetuiging aangeleverd.

242 RVO, 'Pieken in de Delta subsidieregelingen'.
} 
om één keer (technisch) aan te sluiten op het platform en via zorginstellingen en in samenhang met andere leveranciers hun eHealth-toepassingen aan te bieden en daarmee de zorgmarkt te ontsluiten. ${ }^{243}$

Dat leidt tot twee vetgedrukte doelstellingen in de subsidieaanvraag van PAZIO:

\section{'Doelstelling 1. Ontsluiten van de gezondheidszorgmarkt voor ICT-bedrijven.}

Nieuwe toepassingen en diensten die door de ICT-sector voor de gezondheidszorg worden ontwikkeld, hebben tot op heden onvoldoende toegang tot de zorgmarkt. Met PAZIO krijgen de ICT-leveranciers de mogelijkheid om aan te sluiten op het platform en eHealth-toepassingen a an te bieden. Concurrerende leveranciers van eenzelfde type toepassing hebben gelijke toegangsmogelijkheden tot en kansen binnen PAZIO.' ${ }^{244}$

Hoewel de terminologie anders is, is de lijn van denken hier vergelijkbaar met de M\&ICT-subsidieaanvraag van een jaar eerder. Systeemfalen wordt hier als zodanig niet genoemd, maar ook hier is de ambitie om de zorgmarkt toegankelijk te maken voor ICT-leveranciers. Meer nog dan in de M\&ICT-aanvraag is het vertrouwen in de meerwaarde van technologie voor de samenleving, en specifiek van ICT in de zorg, hier onbetwist en onbesproken. Technologie en innovatie worden als vanzelfsprekend meerwaarde voor zorg en samenleving gegeven, los van hoe ze ontworpen of ingebed worden in de maatschappelijke praktijk.

In het kader van de PinDa wordt de functionaliteit van PAZIO, net als eerder in de M\&ICT aanvraag geherinterpreteerd, zonder daarbij andere interpretaties af te vallen. In het kader van M\&ICT werd PAZIO een doorbraakmachine voor systeemfalen, in de PinDa aanvraag wordt ze geframed als 'economische motor voor ICT-bedrijven en dienstverleners'. ${ }^{245}$ Als we de voorstellen mogen geloven sluiten de interpretaties van PAZIO als zorgverbeteraar, patiënten-emancipator, systeemdoorbraakmachine en economische motor elkaar allerminst uit. Ze kunnen alle tegelijkertijd 
worden gerealiseerd met één en dezelfde technologie: het portaal PAZIO is een patiënt-georiënteerd portaal dat ICT leveranciers toegang geeft tot de zorgmarkt.

Naast het geloof in het centraal stellen van de patiënt in de zorg en een geloof in technologie komt er hier andere overtuiging om de hoek

kijken: het geloof in de zorg als markt. PAZIO wordt voor die markt een economische motor genoemd. Naast dat patiënten centraal moeten komen te staan in de zorg, moeten zorgconsumenten vraagmacht creëren op de zorgmarkt. Interessant genoeg zijn die zorgconsumenten (patiënten) wel de beoogde gebruikers, maar niet de beoogde betalers voor PAZIO; dat zijn de zorgaanbieders (zorgverleners). Het begrip zorgconsumenten is in deze dan ook niet onomstreden. Dat geldt niet alleen voor PAZIO of ICT, maar ook voor de gezondheidszorg in breder zin. De zorgconsument valt vrijwel nooit samen met de klassieke klant op andere markten. Het is niet de zorgconsument maar de verzekeraars en overheden die de dienstverlening inkopen en betalen. Deze anomalie wordt door de betrokkenen niet als zodanig ervaren en doet voor hen niet af aan de overtuiging dat de zorg ook een markt is.

De tweede doelstelling van de Pieken in de Delta aanvraag, laat zien dat PAZIO haar bijdrage aan de ontwikkeling van de zorgmarkt niet alleen ziet als een afgeleide of neveneffect van haar doelstelling om de patiënt centraal te stellen. Los van die ambities om de patiënt in het middelpunt te stellen toont PAZIO de ambitie om zich inzetten om ICT-bedrijven te stimuleren en te ondersteunen op de zorgmarkt.

\footnotetext{
'Doelstelling 2. Creëren van nieuwe bedrijvigheid, werkgelegenheid en opleidingsmogelijkheden in de ICTsector door het opzetten en exploiteren van een Centre-ofExcellence op het gebied van eHealth.

PAZIO wordt een Centre-of-Excellence op het gebied van eHealth-toepassingen.... Onderzoek van het Centre-of-Excellence richt zich ook op het identificeren van kansen voor nieuwe zorgtoepassingen met een positieve economische en/of maatschappelijke businesscase. Het Centre-of-Excellence stimuleert en ondersteunt ICT-bedrijven in de regio om deze toepassingen daadwerkelijk te realiseren. Inbedding van deze nieuwe toepassingen in PAZIO vormt een voedingsbodem voor succesvolle uitrol en exploitatie.'246
} 
Met haar zelfbenoemde rol als economische motor wordt het ontsluiten van de zorgmarkt en ondersteunen van ICT-bedrijven een doel op zich. Met het stimuleren en ondersteunen van ICT-bedrijven om technologie te realiseren, werpen de aanvragers zich op als promotor van marktdenken en de inzet van geloof in technologie in de zorg. Die rol staat los van de ontwikkeling van PAZIO en ze wordt niet verbonden met idealen over zorg of de positie van de patiënt in de zorg. Het worden doelen in zichzelf. Dat past goed in de kaders van de Pieken in de Delta aanvraag, waarin economische stimulering van de regio de ambitie is. Ze sluit niet aan op de PAZIO-idealen over de ontwikkeling van een patiënt-georiënteerde zorginformatie omgeving. Weliswaar worden deze oorspronkelijke idealen rond de positie van patiënten niet ontkend, maar ze worden ook niet actief of prominent ingezet. In de beschrijving van de doelstellingen zijn de volgende drie regels gewijd aan de gebruiker:

'Tot slot staat binnen PAZIO het belang van de gebruiker voorop: De gebruiker krijgt via zijn zorginstelling een samenhangend pallet aan eHealth-toepassingen aangeboden, terwijl de vertrouwensrelatie tussen de gebruiker en de vertrouwde zorginstelling in stand blijft. ${ }^{247}$,

Uiteindelijk wordt het belang van de gebruiker ${ }^{248}$ dus expliciet genoemd, maar krijgt het in de beschrijving van de doelstelling niet alleen minder ruimte en een minder prominente plek, maar ze speelt ook geen rol in de verdere argumentaties of afwegingen in de aanvraag. Het is vooral een symbolische sluitpost in de aanvraag, waarin PAZIO primair wordt gepresenteerd als economische motor.

In pragmatische zin is de PinDa aanvraag zonder meer succesvol: ze wordt gehonoreerd met een subsidie van $€ 2$ miljoen. De uitdaging zit erin om aan de verschillende beloften, ambities en overtuigingen achter PAZIO en van de subsidieverleners in de praktijk recht te doen. 


\subsubsection{TERUG NAAR DE KICK-OFF}

De kick-off, waar dit hoofdstuk mee opende, markeert de officiële start van het PAZIO-project op basis van de Pieken in de Deltasubsidie van twee miljoen euro. De bijeenkomst sluit af met de presentatie van de PAZIO-website. De websitepresentatie gaat die middag niet verder dan een screenshot van het scherm en een knal met confetti. Op die site staat meer informatie, maar daar komen we tijdens de kickoff niet aan toe. Ook is er tijdens de kick-off is geen aandacht voor de PowerPointpresentatie over PAZIO, die de deelnemers op een USB-stick na afloop mee naar huis krijgen, naast een map met leaflets over PAZIO. De inhoudelijke kennismaking met PAZIO wordt verlengd tot na de kickoff bijeenkomst. Deze informatiebronnen laten zien hoe de thema's uit de geschiedenis van PAZIO een plek krijgen in dit markeringsmoment van de kick-off.

Hoe krijgen de thema's uit de geschiedenis van PAZIO tot dit moment een plek in de producten rond de kick-off? De website, presentatie en leaflets ${ }^{249}$ maken grotendeels gebruik van overeenkomstige teksten en afbeeldingen en zijn in lijn met de film. Dat is ook niet zo verwonderlijk, ze behandelen allen PAZIO en zijn door dezelfde mensen in dezelfde periode opgesteld. Het centrale idee achter PAZIO is gevangen in de figuur 3.8 die is terug te vinden op de toenmalige website ${ }^{250}$ en de hiervoor besproken presentatie. ${ }^{251}$

In deze figuur 3.8 staat PAZIO centraal. Dat is opvallend: de grote ambitie van PAZIO was aanvankelijk om de patiënt centraal te stellen in de zorg met PAZIO als het middel. PAZIO wordt echter gepresenteerd met nog verschillende andere mogelijkheden: PAZIO verlost mevrouw De Wolf van haar ziekte last en geeft haar 'een beetje vrijheid'. PAZIO zorgt voor betrouwbare informatie, online communicatie, efficiënte bedrijfsvoering, verbetering van de zorgkwaliteit, betere preventie en gezondheid en de mogelijkheid om langer thuis te blijven wonen. Daarnaast zou PAZIO een empowerment tool, economische motor, onderzoeksversneller en zorgverbeteraar worden. PAZIO staat centraal als omnipotente technologie, die onder meer de patiënt centraal zet maar ook zorgverleners en onderzoekers verder helpt. In de leaflets van PAZIO is het als een credo als volgt geformuleerd:

'PAZIO staat voor een Patiëntgeoriënteerde Zorg Informatie Omgeving.... Maar PAZIO staat vooral ook voor een innovatieve 


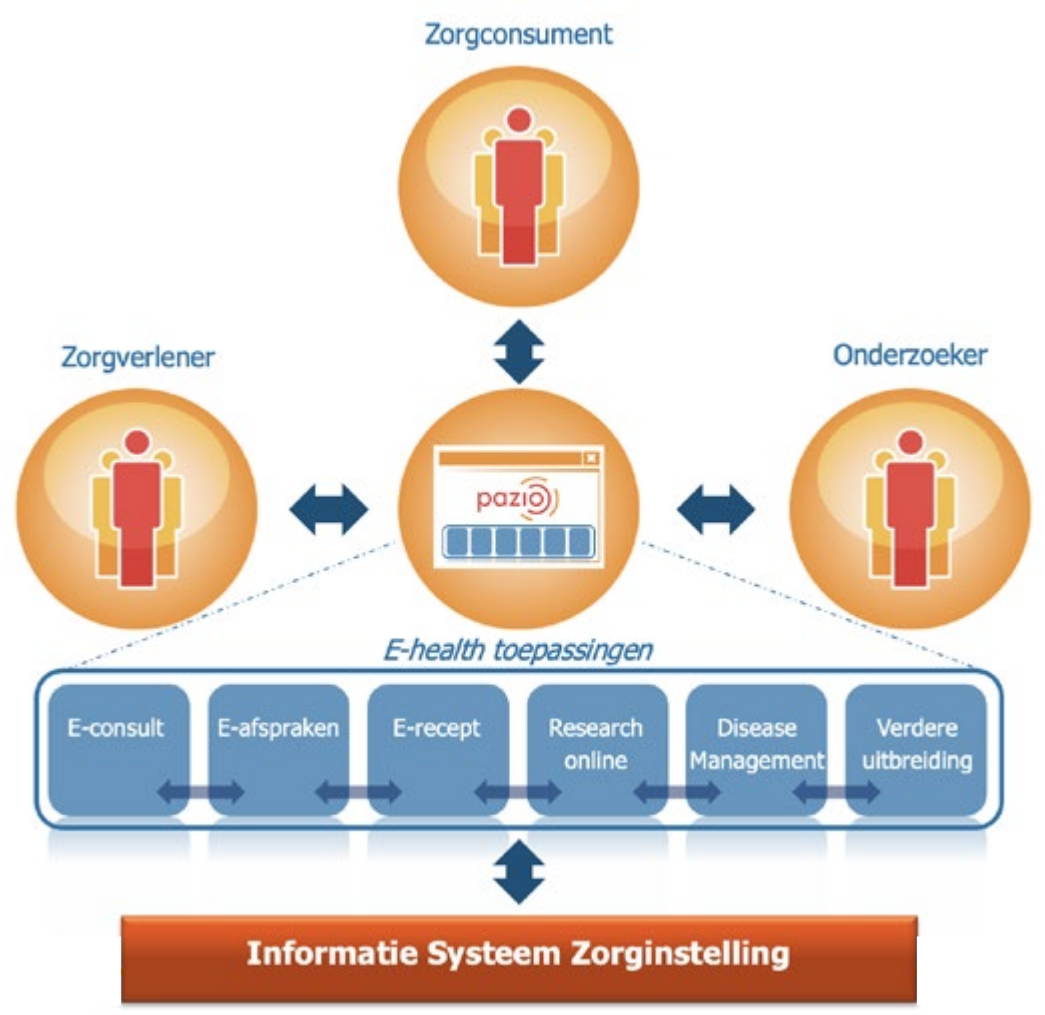

FIGUUR 3.8 Het PAZIO-concept. ${ }^{252}$

gezondheidszorg die kwalitatief beter wordt, efficiënter werkt en daardoor ook morgen nog betaalbaar blijft.' ${ }^{253}$

In het PAZIO-project blijken vier terugkerende motieven zichtbaar:

1. De gezondheidszorg is een groot goed;

2. De gezondheidszorg is een zorgmarkt met daarop zorgconsumenten en zorgaanbieders;

3. De patiënt moet centraal komen te staan in de zorg;

4. Met technologie en innovatie kunnen we de kwaliteit van zorg, de zorgmarkt en de positie van de patiënt verbeteren.

Het vierde motief waarin het belang van technologie en innovatie centraal staat is vrijwel continu aanwezig en een onderlegger bij de 
andere motieven. De positie van de patiënt en het belang van zorg gaan vaak hand in hand. Ze putten deels ook uit dezelfde culturele bron waarin het belang van de autonomie van het individu centraal staat. In het voorlichtingsmateriaal komt het grondmotief van het vertrouwen in de zorgmarkt nauwelijks aan bod. Daar gaat het om de centrale positie van de patiënt en de kwaliteit en efficiëntie van zorg. In het M\&ICT-voorstel en in het gehonoreerde Pieken in de Delta-voorstel is dat andersom. Daar krijgt PAZIO als doorbraakmachine in een falende markt en als economische motor de meest prominente positie, terwijl de patiënt centraal daar slechts tweemaal in een bijzin genoemd wordt. Tijdens de kick-off komen markt en zorg samen in twee prominente bezoekers. De gedeputeerde spreekt daar over de markt, terwijl patiënt mevrouw De Wolf centraal staat als ze op het moment suprême op de rode knop mag drukken.

De manier waarop met retoriek en vormgeving de idealen en ambities in het voorlichtingsmateriaal geconstrueerd worden, is herkenbaar uit de film.

'Stelt u zich eens voor. Dat u makkelijker protocollen kunt ontwikkelen die de mensen en middelen in de zorg niet alleen doelmatiger inzetten, maar ook de kwaliteit van de zorg aantoonbaar verbeteren. Dat u iedereen thuis de mogelijkheid biedt om op een verantwoorde manier aan preventie te doen. En vooral ook chronisch zieken dagelijks op afstand kunt monitoren en ondersteunen. Met PAZIO is dit geen toekomstbeeld meer maar de praktijk van vandaag; één landelijk gezondheidsportaal. En dat is belangrijk nieuws, zeker voor u als zorgverzekeraar.' ${ }^{254}$

Dergelijke beelden van de zorg worden voor vier verschillende gebruikers geschetst en met hen verandert steeds het perspectief op PAZIO. Aan de zorgverzekeraar belooft PAZIO doelmatigheid en verbeterde zorg kwaliteit; aan managers van zorginstellingen een verbeterde bedrijfsvoering en zorg; aan zorgverleners regie in ketenzorg en het betrokken houden van patiënten vanachter het beeldscherm. Tot slot: patiënten krijgen betrouwbare informatie, online communicatie en empowerment door regie bij patiënt, ze kunnen zelf actief meehelpen om gezondheidsklachten te voorkomen. 
'De toekomst van de gezondheidszorg? Wij zijn er alvast mee begonnen'255 is de veel gebruikte frase in de communicatie over PAZIO. Deze paradoxale formulering blijkt karakteristiek voor de communicatie over PAZIO. Daarin wordt continu gespeeld met toekomstbeelden en realiteit. Verlangens, beloften en werkelijkheid, wisselen elkaar af en draaien om elkaar heen. Dat komt het meest pregnant tot uiting in de leaflets waar ze naadloos aan elkaar verbonden worden:

'Stelt u zich eens voor. Dat u vanuit huis, via internet, met al uw vragen over uw gezondheid terecht kunt. En nog eens rustig kunt nalezen wat uw huisarts u eigenlijk vertelde, of waar die oefeningen van uw fysio eigenlijk goed voor zijn. Een site waar $u$ de uitslag van een labtest kunt inzien, een afspraak met uw dokter kunt maken of een herhaalrecept kunt opvragen.

Met PAZIO is dit geen toekomstbeeld meer, maar de praktijk van vandaag; één landelijk gezondheidsportaal. Zo kunt u online met uw arts of andere professionals uit de zorg contact opnemen. Vindt u er betrouwbare informatie over alles wat uw gezondheid aangaat. Ook kunt u zelf actief meehelpen om gezondheidsklachten te voorkomen.' ${ }^{256}$

Op het moment van de kick-off is er nog een lange weg te gaan om tot gebruik van PAZIO door zorgverleners en patiënten te komen. Laat staan dat dit één landelijk gezondheidsportaal is. De bewering dat PAZIO dit alles zou kunnen, betekent dan ook niet dat PAZIO dit vandaag kan, maar dat PAZIO het in principe zou moeten kunnen of misschien beter nog: dat we graag zouden willen dat PAZIO dit zou kunnen. Het is de belofte dat het kan, het verlangen naar verlossing waarin de wens de vader is van de gedachte: het zou zo mooi zijn als dat zou kunnen. Maar voordat het kan, moet er nog heel wat water door de Leidsche Rijn stromen. 


\subsubsection{DE CO-CONSTRUCTIE VAN TECHNOLOGIE EN GELOOF}

Bijker introduceert in zijn Social construction of technology benadering het concept technologisch frame om de dynamiek van de co-constructie van technologie en samenleving te begrijpen. ${ }^{257}$ 'Technological frames provide the goals, the ideas, and the tools needed for action. They guide thinking and interaction. ${ }^{258}$ De hierboven beschreven casus van de ontwikkeling van het geloof in PAZIO kunnen we begrijpen als het ontstaan van een technologisch frame, waarin de doelen, ideeën en gereedschappen te vinden zijn. Het doel met PAZIO is om de patiënt centraal te stellen, de ideeën en het gereedschap om dat te realiseren komen uit wetenschap en technologie. In de ontwikkeling van het project PAZIO gaat het echter niet alleen om doelen, ideeën en gereedschappen. Een dergelijke doel-middel rationaliteit maakt de drijvende kracht niet zichtbaar en geeft daarmee een beperkt zicht op de ontwikkeling van PAZIO. Die ontwikkeling wordt gedreven door geloof, hoop en beloften. Het concept technologische frame sluit dergelijke motiverende zaken zeker niet uit, maar er is vooralsnog weinig aandacht voor. Deze inspiratie voor innovatie krijgt nog nauwelijks een plek in de SCOT-benadering.

Om juist het ontstaan van het project PAZIO te begrijpen is het de moeite waard het geloofsconcept van Durkheim ter hand te nemen waarin de verhalende, inhoudelijke kant van het sacrale zichtbaar wordt. Daarmee ontstaat een beter zicht op de constructie van een geloof in de ontwikkeling van PAZIO. Op het moment dat van PAZIO nog geen sprake is en zich nog nauwelijks een groep of netwerk heeft gevormd, is er ook van geloof geen sprake. De eerste PVZ-notitie vormt zich rond particuliere belangen van de beoogde partners, niet rond een gedeelde overtuiging. Deze overtuiging ontstaat pas als het nodig is: op het moment dat er aanvullende gelden en externe partners nodig zijn. Dan moet men verder kijken dan de eigen particuliere belangen en anderen overtuigen van het belang van PAZIO en is er een wervend verhaal over PAZIO nodig. Dat wervende verhaal steunt niet alleen op feiten en rationaliteit, het spreekt mensen aan op hun zorgen en verlangens en biedt een daarop aansluitend wenkend perspectief. In de PAZIO-probe wordt daarmee ook een missionaire ontwikkeling zichtbaar waarmee geprobeerd wordt nieuwe sociale groepen bij PAZIO te betrekken. 
Het wenkend perspectief komt niet uit de lucht vallen, het ontwikkelt zich in interactie met de context. Voor het geloof in PAZIO betekent dit bijvoorbeeld dat het zich in interactie met subsidiekaders ontwikkelt. De subsidieverleners moeten geloven dat PAZIO de problemen oplost waar de subsidies voor zijn ingesteld. Pas na ruim drie jaar en verschillende subsidieaanvragen, al dan niet afgerond en ingediend, is het geloof in PAZIO zo ver ontwikkeld dat ze een succesvolle subsidieaanvraag doet in het kader van Pieken in de Delta.

Naast het overtuigen van derden is het ontwikkelen van het geloof in PAZIO ook van belang om de verschillende partners aan elkaar en aan PAZIO te binden en zo een gemeenschap te ontwikkelen. Om een gemeenschap te vormen is meer nodig dan een zakelijke optelsom van particuliere belangen. Er is een overstijgend verhaal nodig, niet alleen in de zin van een groter overstijgend gedeeld belang, maar een verhaal met zeggingskracht dat inspireert en verbindt. Dat die overtuiging tegelijkertijd grote betekenisflexibiliteit kent en multi-interpretabel is, doet aan haar kracht allerminst af, sterker nog: daarin schuilt voor een aanzienlijk deel haar kracht. De betekenisflexibiliteit vertaalt zich in PAZIO als een omnipotent portaal. In het vertrouwen in de techniek en de toekomst is ruimte voor iedereen en kan iedere partij tot zijn recht komen. Door een gedeeld geloof te creëren, ontstaat ook vertrouwen in elkaar. De betrokkenen delen een visie, een ambitie en een verhaal, ze horen bij elkaar en verbinden zich rond de beloften van het omnipotente portaal PAZIO. ${ }^{259}$

PAZIO wordt, zoals Van Lente dat noemt, neergezet als promising technology, beloftevolle technologie. ${ }^{260}$ Met belofte wordt allereerst een verbinding gelegd tussen het heden en de toekomst. Rond PAZIO wordt volop met heden en toekomst gespeeld en is het niet altijd duidelijk dat de beloften voor de toekomst nog wel gerealiseerd moeten worden, dat PAZIO vooralsnog geen beschikbaar artefact is en dat er geen garanties voor de toekomst zijn. Beloften hebben niet alleen een temporeel verbindende kracht, volgens Van Lente. Ze leggen ook verbindingen tussen actoren, tussen technische en maatschappelijke zaken, tussen de binnen- en de buitenkant van een project.

De PAZIO-probe laat zien wat de dynamiek is die zorgt voor promising technology, maar ze laat tegelijk ook zien dat het om meer gaat dan de beloften van technologie. Geloof draait ook om zaken als waarden, verwachtingen, overtuigingen, vanzelfsprekendheden, inspiratie. Het werk van Immanuel Kant biedt drie vragen waarmee we het geloof, in dit geval in PAZIO, verder kunnen ontleden en doordenken aan de hand 
van drie vragen: 1) Wat kan ik weten? 2) Wat moet ik doen? 3) Wat mag ik hopen? ${ }^{261}$ Dat sluit aan bij het basale onderscheid waarop Durkheim zijn religiebegrip baseert, het onderscheid tussen het sacrale en profane helpt bij de beantwoording van deze fundamentele vragen. ${ }^{262}$

Het concept technologisch frame wordt sterker als het niet alleen oog heeft voor de beloften die worden toegeschreven aan technologie, maar breder oog heeft voor het geloof in technologie. Dat geloof staat niet op zichzelf, maar is onderdeel van een sacrale vorm waarin rituelen en gemeenschapszin ook factoren zijn. Aandacht voor geloof in technologische verandering geeft zicht op andere aspecten van een technologisch frame. Daarnaast kan het helpen de eenheid in verscheidenheid van het technologisch frame te ontdekken, want vooralsnog wordt ze veelal ingezet als een verzamelbox voor diverse zaken zoals ideeën, doelen en gereedschappen. Duidelijk is dat die zaken ergens wel met elkaar in verband staan, maar dat verband is moeilijk te expliciteren en wordt dan ook niet altijd uitgewerkt. Aandacht voor geloof en de sacrale vorm in Durkheimiaanse zin kan helpen om de op het eerste gezicht onzichtbare eenheid zichtbaar te maken. De ontstaansgeschiedenis van PAZIO is niet te begrijpen als we geen oog te hebben voor de constitutionele rol die grondmotieven, idealen, beloften en verwachtingen spelen in het proces. Daarmee is het zaak om naast technische en sociale aspecten van de PAZIO-probe ook te kijken naar wat Dooyeweerd noemt het pistische aspect, de PAZIO-probe te duiden in religieuze termen en op zoek te gaan naar de inhoud en rol van het geloof in PAZIO.

\subsubsection{HET PAZIO-GELOOF}

Wat is het geloof dat ontstond met het verkrijgen van subsidie voor en opzetten van het project PAZIO? Het geloof wordt het meest expliciet gepresenteerd tijdens de kick-off bijeenkomst en het meest meeslepend in de daar vertoonde film. Daar wordt het onderscheid tussen het sacrale en profane het meest duidelijk zichtbaar.

De films en stukken die in het kader van de ontwikkeling van PAZIO zijn gemaakt schetsen een profane gebroken wereld vol imperfecties, problemen en onzuiverheden: systemen integreren niet, marktwerking en innovatie worden belemmerd door systeemfalen, de gezondheidszorg is slecht georganiseerd, inefficiënt en vol van perverse financiële prikkels en in de zorgpraktijk is sprake van gebrekkige communicatie, onbetrouwbare informatie en een marginalisering van de patiënt. Je zou je haast af gaan 
vragen hoe we het ooit zo ver hebben kunnen laten komen en hoe er überhaupt nog sprake kan zijn gezondheidszorg. De verlosser van al die onvolkomenheden wordt in de film aangekondigd: PAZIO. De film neemt je mee in een meeslepend beeldverhaal en creëert - als je je eraan over kunt geven - een sublieme ervaring, waarin PAZIO een omnipotent portaal is en ons verlost van alle bovenstaande problemen. PAZIO is promising technology. Hoe ze die belofte gestand gaat doen wordt nauwelijks toegelicht, maar duidelijk wordt dat PAZIO bijvoorbeeld de patiënt centraal wil stellen in de zorg. Ze biedt een digitale basis voor de gezondheidszorg en daarmee voor het streven naar gezondheid. PAZIO doorbreekt systeemfalen en marktimperfecties, ze geeft de patiënt meer vrijheid, autonomie. Vrijheid wordt hier flexibel geïnterpreteerd en vooralsnog gevarieerd ingevuld. Soms is vrijheid een vorm van taakherschikking: als patiënt mag je nu doen wat eerst alleen de zorgverlener deed: dossiers inzien. Op een ander moment is het een mogelijkheid om te participeren of in ieder geval op andere, digitale wijze te communiceren. Je wordt geacht op basis van betrouwbare informatie beter te kunnen beslissen over je eigen zorg en daarmee meer regie te gaan voeren. Het geloof in PAZIO kent daarmee wel intrinsieke spanningen, bijvoorbeeld tussen het streven naar vrijheid voor de patiënt en de drang naar beheersing en controle in het streven naar efficiëntie en evidence based werken in de gezondheidszorg. Daarnaast brengt ziekte en zorg een welhaast intrinsieke noodzaak tot overgave met zich mee. Die bestrijden met een streven naar vrijheid, regie en autonomie kan al snel ontaarden in vechten tegen de bierkaai en niet aansluiten bij de behoefte van de patiënt in kwestie. Dat alles neemt niet weg dat het geloof in vrijheid, gezondheid en techno-wetenschappelijke innovatie buiten kijf staat. De kracht van dit geloof zit in haar vermogen om te inspireren en te verbinden en niet zozeer in haar consistente redenaties.

In navolging van Durkheim kan dit geloof in PAZIO een specifieke ordening van het sacrale, een sacrale vorm, genoemd worden. Het gaat daarbij niet alleen over ordening van wat er in de wereld is, het is ook de bril waarmee men naar die wereld kijkt en zo die orde mee construeert. Ook in een moderne, zelfbenoemd seculiere en technologische cultuur zijn er ideeën, uitgangspunten en overtuigingen die zo vanzelfsprekend en breed gedeeld zijn, dat ze geen betoog of onderbouwing behoeven. Het zijn de waarden, idealen en ideeën die apart gezet worden en zo een sacrale vorm vormen. Met een sacrale vorm wordt onder meer uitgedrukt wat in een bepaalde context als de ultieme waarheid en waarde of, om met de filosoof Dooyeweerd te spreken, de grondmotieven zijn. Het geloof, in dit geval in PAZIO, geeft het verhaal over de aard van het sacrale en hoe dat zich verhoudt tot activiteit (wat kan men doen?) en moraliteit (hoe behoort men zich te gedragen?), en het kent eigen verwachtingen en hoop. 
Op basis van de kick-off en daarin vertoonde film kunnen we de hiervoor genoemde drie geloofsbepalende vragen van Kant voor PAZIO als in een catechismus $^{263}$ beantwoorden.

1. Wat kan ik weten? - het begrijpen:

In het geloof in PAZIO begrijpen we de wereld in termen van individuele autonomie, gezondheid, emancipatie, efficiëntie, marktwerking, informatie en communicatie in de gezondheidszorg. Het probleem is de imperfectie van deze zaken;

2. Wat moet ik doen? - de actie:

Door innovatie met behulp van wetenschap en techniek kunnen we deze imperfecties te niet doen;

3. Wat mag ik hopen? - de beloften en verwachtingen:

We mogen erop rekenen dat we met behulp van technologische innovatie de gezondheid en vrijheid van mensen kunnen vergroten en ze verlossen van ziekte, beperkingen en afhankelijkheden, en dat dit door marktwerking op effectieve en efficiënte wijze kan gebeuren.

De hierboven gegeven kern van het geloof in PAZIO betekent allerminst dat we het geloof van PAZIO moeten opvatten als een enkelvoudig, eenduidig en consistent idee. Religie kan niet worden gereduceerd tot één uniek principe. Eerder is het een geheel dat bestaat uit relatief onafhankelijke onderdelen. ${ }^{264}$ Zo omnipotent als PAZIO beschreven wordt, zo multi-interpretabel zijn de idealen en overtuigingen achter PAZIO. Om te spreken in de termen van Bijker: de betekenisflexibiliteit van PAZIO is groot. Vanuit zijn theory of sociotechnical change mogen we daarom voorzichtig aannemen dat PAZIO en de gemeenschap daaromheen met haar bijbehorend technologische frame nog niet uitgekristalliseerd zijn. Dat is ook niet verwonderlijk. Dit hoofdstuk startte met de kick-off en duidelijk werd dat PAZIO aan het begin staat van haar ontwikkeling. Er is nog geen hard product. Hier zijn slechts verhalen over PAZIO, gevuld met een variëteit aan overtuigingen, verlangens en beloften. Dat alles moet nu, na het verkrijgen van een grote subsidie gerealiseerd worden. Want een technologie ontstaat niet door geloof alleen.

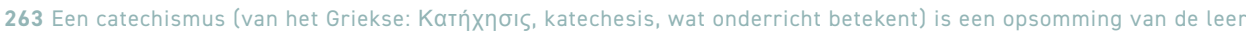
van een bepaald kerkgenootschap waarin al zijn dogma's systematisch en voor leken begrijpelijk worden gegeven en uitgelegd. Omdat ze een middel zijn bij de catechese, worden ze vaak in vraag- en antwoordvorm uitgegeven. Wikipedia, 'Catechismus'. 






\section{HET RITUALISEREN VAN DE TECHNOLOGISCHE PRAKTIJK}

\subsection{INLEIDING}

In Durkheims benadering van religie zijn drie elementen van belang: geloof, rituelen en gemeenschap. In hoofdstuk 3 stond het geloof centraal, in dit hoofdstuk ligt de focus op rituelen rond PAZIO. Ik analyseer daarbij het implementatieproces van PAZIO in de praktijk van de Leidsche Rijn Julius Gezondheidscentra in de periode van januari 2010 tot en met mei 2011.

\section{Routines en rituelen}

Uit het technologieonderzoek is bekend dat technologie in de praktijk alleen werkt als ze verweven is met routines. ${ }^{265}$ In de zorg is het gebruik van technologie een onmiskenbaar onderdeel van het werk en komt het gebruik daarvan vaak precies. Dat wordt bijvoorbeeld zichtbaar in operatiekamers vol apparatuur en in de spreekkamer waar medicatie wordt voorgeschreven en consulten worden vastgelegd in het patiëntendossier. De ontwikkeling van procedures en routines is dan ook een essentieel onderdeel van de implementatie van technologie in een zorgpraktijk. In de ontwikkeling spelen zowel patiënten als zorgverleners een rol. Patiënten krijgen bijsluiters bij geneesmiddelen en meer of minder uitgebreide instructies en begeleiding door de 
apothekers of zorgverleners bij geneesmiddelengebruik, oefeningen of andere therapeutische interventies. Zorgverleners krijgen instructies, trainingen en handleidingen voor het gebruik van medische technologie. Je moet immers goed weten hoe de technologie werkt, voordat je ermee kan en mag werken. Het gaat om het opdoen van tacit knowledge, ervaringskennis en vaardigheden. Vrijwel iedere geneeskundige- of zorgopleiding kent daarom praktisch onderwijs in de vorm van stages en coschappen waarin routines worden geleerd en ingeoefend. De ontwikkeling van routines gebeurt voor een aanzienlijk deel in de praktijk. Routines hebben veel gemeen met rituelen, het zijn uitgekristalliseerde en ingesleten handelingen met een duidelijk doel. Rituelen onderscheiden zich van routines doordat ze gericht zijn op het sacrale. In dit hoofdstuk wordt onderzocht of er bij de implementatie van PAZIO gesproken kan worden van de ontwikkeling van rituelen.

\section{Leeswijzer}

Ik begin de analyse bij de vergadering aan het eind van deze periode, waarin de werking van PAZIO van in de praktijk van LRJG wordt gedemonstreerd. De werkprocessen voor PAZIO zijn dan uitgekristalliseerd en worden besproken. Vervolgens bespreek ik het implementatietraject van PAZIO binnen LRJG dat vooraf is gegaan aan de demonstratie: begin 2010 wordt een eerste implementatiepoging gedaan bij de LRJG-locatie Parkwijk. Helaas is die niet succesvol. Het proces wordt geëvalueerd en er ontstaan spanningen tussen het PAZIO-management en de LRJG-directie over de oorzaken en oplossingen. Uiteindelijk wordt er een revitaliseringsplan geschreven en een tweede implementatie opgestart bij de LRJG-locatie Vleuterweide. Daarin werden parallel aan elkaar rituelen ontwikkeld voor de verschillende onderdelen van PAZIO: het portaal Julius Online, eConsult en eAfspraak. Die onderdelen worden stuk voor stuk beschreven. Het hoofdstuk sluit af met de conclusies over de ontwikkeling en werking van rituelen rond PAZIO.

\subsection{DE DEMONSTRATIE VAN PAZIO - EEN OOGGETUIGENVERSLAG}

Het is vrijdag 27 mei 2011, 8.35 uur. Vandaag staat een belangrijke vergadering gepland, voor PAZIO, voor LRJG en voor mij. Vandaag moet PAZIO overtuigen. Niet zozeer als concept of techniek, maar als meerwaarde in de praktijk van het LRJG. PAZIO moet laten zien dat ze werkt; daarvan moeten de aanwezigen vandaag overtuigd raken. Op verzoek van de voorzitter van de PAZIO-stuurgroep is voor hem en voor het management van LRJG een PAZIO-demo georganiseerd. Vandaag willen de voorzitter van de stuurgroep Kuilboer, de directeur van 
LRJG, Oomes en medisch directeur en hoogleraar huisartsgeneeskunde, De Wit zien dat PAZIO werkt en overtuigende antwoorden horen op hun vragen.

We zitten in de bestuurskamer van de Raad van Bestuur van het UMCU. A. Dekker en Schuttelaar proberen de beamer en personal computer aan de praat te krijgen. Straal, huisarts en lid van het implementatieteam sluit zich bij ons aan. De bestuurders Kuilboer en Oomen en hoogleraar De Wit komen ook binnen, maar de beamer doet het nog niet. Flikweert stelt voor om de agenda om te draaien en te beginnen met het communicatieplan en daarna de demo te doen.

In het communicatieplan staat dat voor patiënten het gebruik van PAZIO nog niet vanzelfsprekend is en dat het van belang is om hen te informeren, te activeren en zo het gebruik te continueren. De tone-of-voice van de communicatie naar de patiënt moet 'formeel maar vertrouwd zijn', de look-and-feel moet 'aantrekkelijk en verzorgd' zijn en de communicatietaken en -rollen worden verdeeld. ${ }^{266}$ De centrale boodschap is:

'online diensten betekent samenwerken aan de zorg door de zorglener en de patiënt. De patiënt kan LRJG in zijn eigen tijd een bericht sturen en een afspraak maken. In deze 24/7 economie is het bijna ouderwets dat de patiënt alleen via de telefoon of consult met de huisarts kan communiceren. De patiënt krijgt hierdoor meer regie over zijn eigen zorgproces. ${ }^{267}$

Er wordt even verder gesproken over het communicatieplan. Er worden een paar kritische opmerkingen gemaakt, vragen gesteld en beantwoord. Het communicatieplan wordt vervolgens zonder grote problemen goedgekeurd. De demo is de werkelijke proof of the PAZIO-pudding; daar zijn we allemaal voor gekomen.

De naam PAZIO is onzichtbaar in deze demo. PAZIO neemt hier de look-and-feel van de huisstijl van de website van het LRJG over. In deze demo moet immers gedemonstreerd worden dat PAZIO onder de naam Julius Online klaar is voor gebruik bij de Leidsche Rijn Julius Gezondheidscentra. PAZIO bouwt verder op de bestaande behandelrelatie tussen LRJG en haar patiënten, maar ze moet daar niet als zichtbare entiteit tussen gaan zitten. De aanwezigen kunnen op de beamer volgen hoe ik als patiënt bij Julius Online inlog met DigiD. Kuilboer merkt op dat DigiD een spannende drempel voor gebruik is, maar dat we daar desondanks allen voor kiezen om redenen van privacy en veiligheid. Ik klik door naar 
het profiel van de gebruiker: alle relevante persoonsgegevens staan erin. Sommige zijn door de patiënt aan te passen, andere zijn onlosmakelijk verbonden aan het burgerservicenummer en niet door de patiënt zelf te wijzigen. Ik geef aan dat de verzekeringsgegevens niet standaard in het profiel staan. De Wit merkt op dat als er geen verzekering is, declaratie ook niet mogelijk is. Ik licht toe dat het hier alleen om de zichtbaarheid van de gegevens gaat, niet zozeer over de vraag of mensen een zorgverzekering hebben. Straal vult aan dat er een VeCoZo-check ${ }^{268}$ zit in het huisartsinformatiesysteem van Medicom. A. Dekker geeft aan dat de leverancier van Medicom, PharmaPartners, werkt aan een koppeling met het Julius Online profiel.

Ik ga verder en demonstreer de eAfspraak module. De directeur bedrijfsvoering Oomes vraagt of de triage bij het online maken van afspraken overgeslagen wordt. Ik bevestig dat en heb het vermoeden dat hij zich zorgen maakt over de vraag of er geen onnodige consulten worden ingeboekt. Niets is minder waar: Oomes concludeert dat als triage online niet nodig is, het ook niet nodig is bij telefonische afspraken en daar dus bespaard kan worden. De huisartsen Straal en De Wit reageren daar direct op. Straal merkt op dat spoedplekken niet via eAfspraak geboekt kunnen worden en juist bij deze spoedplekken triage van belang is. De Wit vult aan dat triage gericht is op het maken van een juiste inschatting van het doel van de afspraak en niet gericht is op het eventueel weigeren van een afspraak.

Ik laat zien dat binnen Julius Online ook een Diabetes Zelf Management module beschikbaar is. ${ }^{269}$ De Wit geeft daarbij aan dat deze nog niet gebruikt wordt. Eerst moeten de te volgen procedures door collega-huisarts Hart inhoudelijk en procesmatig moet worden afgedicht. A. Dekker benadrukt dat door VitalHealth Software aan alle LRJG eisen en wensen is voldaan en dat daarmee een morele verplichting richting de leverancier ontstaat, waarop De Wit benadrukt dat het protocol van essentieel belang is om tot gebruik over te gaan. Kuilboer erkent het belang van zorgvuldigheid in deze en geeft aan dat LRJG daarbij in de lead is. A. Dekker heeft zijn punt echter gemaakt: de techniek staat klaar, LRJG is hier de remmende factor: zij hebben hun protocollen nog niet op orde.

Ik demonstreer vervolgens hoe een patiënt actief kan uitloggen uit Julius Online en merk op dat dit ook vanzelf gebeurt als de internetbrowser wordt gesloten. LRJG heeft eerder besloten dat ze het portaal 
Julius Online in eerste instantie zo wil integreren dat het de patiënt optimaal faciliteert. We noemden dat 'portaal-integratie'. Daarmee werd het gebruikersgemak en de onlineservice voor de patiënten geoptimaliseerd. Dat ging ten kostte van de 'HIS-integratie', dat wil zeggen de koppeling tussen het huisarts informatiesysteem en Julius Online. Dat maakte het Julius Online minder gebruiksvriendelijk voor de zorgverleners. Zij moeten vooralsnog in twee systemen, of zoals vaak gezegd werd, 'op twee schermen' werken. Ik kondig aan dat ik PAZIO nu zal benaderen vanaf de zorgverlenerskant. Kuilboer merkt meteen op dat 'de klikbaarheid en integratie voor de patiënt mooi is'. ${ }^{270}$ Flikweert kondigt hierop aan dat de ontwikkeling van de zorgverlenerszijde vanaf nu prioriteit heeft.

De Wit en Oomes zijn al overtuigd door de demo, de zorgverlenerszijde roept geen bijzondere vragen meer op. Kuilboer concludeert: 'dit is een belangrijk moment, we gaan nu de markt op.' ${ }^{271}$ Ofwel: we kunnen PAZIO nu in de zorgpraktijk gaan gebruiken en aan patiënten aanbieden. De aanwezigen erkennen dat en gaan op zoek naar een geschikt moment, waarbij de grote vraag is of dat nog voor de zomer of toch beter daarna kan. Flikweert merkt terloops op dat er vanochtend alweer nieuwe meldingen van patiënten via Julius Online waren. De Wit vraag wat verschrikt: hoe kan dat? De verklaring is dat het systeem al open staat sinds de vorige implementatiepoging van begin $2010 \mathrm{op}$ Parkwijklocatie van LRJG. Oomes merkt op: 'de interne werkprocessen moeten dan wel op orde zijn.' ${ }^{272}$ Kuilboer neemt als voorzitter het heft in handen en grijpt terug naar het moment voor de lancering: '15 augustus lijkt me een goed vlagmoment, het succes zit bij jullie' ${ }^{273}$, verwijzend naar LRJG. Nu de kogel door de kerk is, ontspannen de aanwezigen.

Oomes merkt lachend op: 'ik denk dat het gaat gebeuren. Er is veel gebeurd, in moeilijke tijden hebben we stug vol gehouden, mijn complimenten.'

De Wit: 'Ik heb er altijd in geloofd, de techniek moet de praktijk ontmoeten.'

Kuilboer: 'Het is ook een geloof in professionals en managementondersteuning.'

Na tijden vol onderlinge spanningen, twijfels en soms ook wel verwijten, spreken de aanwezigen met terugwerkende kracht een expliciet en groot geloof in Julius Online uit. 
Kuilboer bedankt me voor mijn inzet en de mooie resultaten. Hij overhandigt me daarbij het boek Verlangen naar verbetering - 375 jaar academische geneeskunde in Utrecht waarin de geschiedenis van het UMCU als innovatieve onderneming wordt beschreven. ${ }^{274}$ Met deze afsluiting en dit cadeau markeert hij de afronding van een fase en bevestigt hij het geloof in PAZIO nu dat we de markt op gaan.

\subsection{DE AMBITIES EN TRADITIES VAN LRJG}

Het pilotimplementatietraject van PAZIO vindt plaats bij de Leidsche Rijn Julius Gezondheidscentra. LRJG is één van de partners van het eerste uur in het PAZIO-project. Ze is als eerstelijns gezondheidscentrum steeds de beoogde pilot locatie en launching customer voor PAZIO geweest. Om de context van het PAZIO-pilot implementatietraject te begrijpen, wordt allereerst een introductie van het LRJG gegeven met daarin oog voor de ambities die ze heeft en de traditie waarin ze staat.

De stichting LRJG is eind twintigste eeuw opgericht door onder andere ${ }^{275}$ het UMC Utrecht en ontwikkelt en beheert sindsdien gezondheidscentra in de Utrechtse VINEX-locatie Leidsche Rijn aan de westkant van Utrecht. De oprichters hadden met LRJG de ambitie

'om multidisciplinaire geïntegreerde eerstelijns zorg te gaan aanbieden vanuit een academische context. In de Leidsche Rijn zou via LRJG de eerstelijnszorg van de toekomst gerealiseerd worden. LRJG zou een academische praktijk worden waarbij veel aandacht besteed zou worden aan zorginnovaties, onderwijs en wetenschappelijk onderzoek.' ${ }^{276}$

LRJG groeit mee met Leidsche Rijn en omvat in 2010 vier locaties in vier verschillende wijken van Leidsche Rijn: Parkwijk, Veldhuizen, Terwijde en Vleuterweide, waarvan Parkwijk de oudste is. In die vier praktijken worden in totaal zo'n 30.000 patiënten bediend.

Begin 2010 landt PAZIO in de bestaande LRJG-praktijk. Die praktijk functioneert dan al jaren zonder het PAZIO-portaal. PAZIO komt dus niet

\footnotetext{
274 Klijn, Verlangen naar verbetering.

275 De oprichters: Districts Huisartsen Vereniging, Agis Zorgverzekeringen, St. Antoniusziekenhuis, GG\&GD gemeente

Utrecht en UMC Utrecht. Zie: Oomes, Jan, en Niek de Wit. Jaarverslag 2012 Leidsche Rijn Julius Gezondheidscen-

tra. Tekstdocument, 2012.
}

276 Oomes en De Wit. Jaarverslag 2012 Leidsche Rijn Julius Gezondheidscentra. Tekstdocument, 2012, 3. 
in een lege, open ruimte, maar moet haar weg vinden in een draaiende praktijk met zijn gevestigde orde, tradities en manieren van denken en doen.

Hoe kunnen we die LRJG-praktijk begrijpen? Verkerks Triple I Model leert ons dat de zorg ten diepste een morele aard heeft. ${ }^{277}$ In de zorg wordt geld verdiend, er wordt gewerkt in gebouwen met wacht-, spreek- en behandelkamers en er zijn juridische kaders. De zorg is er echter primair op gericht en bedoeld om zorg te dragen voor mensen. Andere zaken kunnen zich naar de voorgrond dringen of afleiden, maar dat neemt niet weg dat goede zorg voor mensen de bestaansreden, legitimatie en motivatie van de zorg is. Dat wordt goed zichtbaar in de eed die geneeskundestudenten afleggen als zij toetreden tot de gemeenschap van artsen. ${ }^{278}$ De eed opent met:

'Ik zweer/beloof dat ik de geneeskunst zo goed als ik kan zal uitoefenen ten dienste van mijn medemens. Ik zal zorgen voor zieken, gezondheid bevorderen en lijden verlichten. Ik stel het belang van de patiënt voorop en eerbiedig zijn opvattingen. Ik zal aan de patiënt geen schade doen. Ik luister en zal hem goed inlichten. Ik zal geheimhouden wat mij is toevertrouwd.'279

Alles draait in deze eed om goede zorg voor de medemens en dat is wat de aspirantarts belooft. De eed schetst geen medisch inhoudelijk beeld, maar een relationeel beeld van de zorg. Goede zorg kan alleen worden gerealiseerd binnen een goede behandelrelatie. In zo'n goede behandelrelatie staat het belang van de patiënt centraal en is er transparantie en vertrouwelijkheid. Naast deze ideële beschrijving in de eed is de behandelrelatie ook formeel in juridische kaders vastgelegd in de Wet op de geneeskundige behandelingsovereenkomst (WGBO), ${ }^{280}$ waarin zaken als informatieplicht, toestemmingsvereiste, goed hulpverlenerschap, dossierplicht en inzagerecht, geheimhouding en privacy geregeld zijn. Meer praktijkgericht is de behandelrelatie voor de huisarts uitgewerkt door de NHG in het idee van 'continue, integrale en persoonlijke zorg'. ${ }^{281}$ De eed bevestigt hoeveel belang er gehecht wordt aan de behandelrelatie tussen zorgverlener en patiënt in de zorg.

277 Verkerk e.a., 'Professional practices and user practices: an explorative study in health care'.

278 Commissie Herziening Artseneed, Nederlandse artseneed.

279 Commissie Herziening Artseneed, 6.

280 Burgelijk wetboek, Wet op de geneeskundige behandelingsovereenkomst.

281 Commissie Wetenschappelijk Onderzoek van het NHG., 'Woudschotenrapport: rapport over de taak van de huisarts, de zogenaamde Woudschotenmaterie.' 
In de artseneed is er overigens wel een tweede belangrijk onderdeel waar de aspirantarts zich met de eed aan verbindt en waarmee de arts werkt aan goede zorg: het ontwikkelen en zorgvuldig benutten van kennis.

'Ik zal de geneeskundige kennis van mijzelf en anderen bevorderen. Ik erken de grenzen van mijn mogelijkheden.... Ik maak geen misbruik van mijn medische kennis, ook niet onder druk. Ik zal zo het beroep van arts in ere houden.' ${ }^{282}$

De tekst van de eed is geen dode letter of slechts ideële achtergrondmuziek in de zorg. Volgens het grote Woordenboek der Nederlandsche Taal is een eed een 'plechtige verklaring, volgens een voorgeschreven formulier en onder aanroeping van iets heiligs' ${ }^{283}$ De eed is een belangrijk onderdeel van het professionele kader van artsen en steeds vaker ook andere zorgverleners. Ze wordt actief gebruikt in het geneeskundig onderwijs. De eed markeert ook de initiatie van de geneeskunde student tot geneeskundige en staat centraal in het initiatieritueel. Iedere aspirant arts sluit zijn/haar studie af met het plechtig en publiekelijk uitspreken van de belofte of eed: 'Dat beloof ik' of 'Zo waarlijk helpe mij God almachtig.'284

De zorg is naast een moreel geladen praktijk ook een praktijk met een lange traditie. Dit is niet de plek om die traditie in detail te beschrijven, hier volstaat het om beknopt aan te geven in welke traditie LRJG staat. Ik grijp daarvoor terug naar de oratie die De Wit uitsprak bij de aanvaarding van het ambt van hoogleraar in de Huisartsgeneeskunde aan de faculteit geneeskunde van de Universiteit Utrecht op 11 november 2010. ${ }^{285} \mathrm{Hij}$ was begin dat jaar ook net benoemd als medisch manager bij LRJG. Zijn in de oratie geëxpliciteerde beeld van de geschiedenis is daarmee ook een relevant onderliggend verhaal binnen de LRJG-praktijk. De Wit vertelt hoe de arts generalist van alle tijden was. In de jaren vijftig van de vorige eeuw ontstond de behoefte aan wetenschappelijke onderbouwing van zijn werk. Dat was één van de aanleidingen om in 1956 het Nederlands Huisartsengenootschap (NHG) op te richten. Tijdens een bijeenkomst in 1959, die binnen de huisartsengemeenschap bekend staat als de Woudschotenconferentie, bakenden zij het huisartsgeneeskundige vakgebied af als 'de verantwoordelijkheid voor de continue, integrale en persoonlijke zorg aan 
de patiënten die aan de huisarts zijn toevertrouwd. ${ }^{286,287}$ In de jaren daarna werden gaandeweg professionele behandelstandaarden ontwikkeld, in de praktijk beter bekend als de NHG-standaarden, die tot op de dag van vandaag een belangrijke rol spelen in de eerstelijns zorg. De Wit concludeert dat er in vijftig jaar tijd een aanzienlijke professionalisering heeft plaatsgevonden en er ook in organisatorisch opzicht een ontwikkeling zichtbaar is. 'Tegenwoordig kennen we een huisartsenvoorziening waarin huisartsen, steeds vaker een vrouw, steeds meer op deeltijdbasis zorg aanbieden via taakdelegatie, zorgprogramma's en een dienstensysteem.' ${ }^{288}$ De huisarts is echter nog steeds poortwachter en heeft een centrale rol in de Nederlandse gezondheidszorg. Om dat te blijven moet de huisarts anticiperen op maatschappelijke en demografische ontwikkelingen. De patiënt verandert, volgens De Wit, 'van een passieve zorgvrager in een betrokken consument. Dit dwingt huisartsen te investeren in voorlichting, zelfmanagement en gedeelde besluitvorming in het behandelplan.' ${ }^{289} \mathrm{De}$ afgelopen jaren zijn daartoe een aantal academische huisartspraktijken opgericht, waaronder Stichting Julius Gezondheidscentra die inhoudelijk en bestuurlijk verbonden is aan het Universitair Medisch Centrum Utrecht. Naast basiszorg en aanvullende zorg biedt ze 'een innovatief zorgaanbod, in de voorhoede van medische ontwikkelingen in de eerste lijn.' ${ }^{290}$

De artseneed, wetgeving en de geschiedenis van de eerstelijnszorg laten zien dat het streven naar goede zorg onverminderd centraal staat binnen de eerstelijnszorg in het algemeen en in de praktijk van LRJG. Innovatie en de behandelrelatie zijn belangrijke, vanzelfsprekende en onaantastbare grondmotieven voor de LRJG-praktijk. We zien deze grondmotieven terug in de inrichting van de praktijk: in de manier waarop er afspraken gemaakt worden, in de inrichting van het gebouw met wacht-, spreek- en behandelkamers. De beslotenheid van de spreekkamer, de vertrouwelijkheid van wat daarbinnen uitgewisseld wordt, de zorg die verleend wordt en wordt vastgelegd in vertrouwelijke patiëntendossiers zijn uitingen van de idealen rond de behandelrelatie. De hele praktijk is georganiseerd rond de idealen goede zorg, innovatie en behandelrelatie. Dat betekent allerminst dat daarmee de praktijk onwrikbaar vastligt.

286 Commissie Wetenschappelijk Onderzoek van het NHG., 'Woudschotenrapport: rapport over de taak van de huisarts, de zogenaamde Woudschotenmaterie.'

287 Voor de context en het ideologisch belang van deze conferentie zie: Werf en Zaat, 'De geboorte van een ideologie: Woudschoten en de huisartsgeneeskunde'. 288 Wit, Huisartsgeneeskunde: van alledaagse romantiek naar academische praktijk, 12. 
Ontwikkelingen aan de zorgverlenerskant en een nieuwe visie op de rol van patiënten zorgen voor veranderingen in de zorg en in de behandelrelatie. De afgelopen decennia is de huisarts die continue, integrale en persoonsgerichte zorg leverde vervangen door een gemeenschap van artsen, assistenten, POH's in de (eerstelijns)praktijk. Een patiënt heeft niet meer altijd hetzelfde gezicht voor zich, maar spreekt, ziet en ontmoet in de eerstelijnspraktijk vele zorgverleners. Dat heeft invloed op de behandelrelatie. De zorg mag nog steeds persoonsgericht, continu en integraal genoemd worden, de persoonlijke band tussen patiënt en zorgverlener is aan erosie onderhevig. Daarnaast leeft er binnen LRJG de ambitie om de patiënt meer zelf te laten doen. Er wordt hard gewerkt aan zelfmanagement en shared decision making, waarin de patiënt geacht wordt preventief en curatief aan zijn gezondheid te werken en samen met de zorgverlener beslissingen te nemen over het te bewandelen zorgtraject. Dat vraagt van de patiënt zelf een toenemende aandacht voor zelfzorg en verandert de rollen en verantwoordelijkheden in de behandelrelatie. LRJG staat in een stevige traditie en is tegelijkertijd continu in ontwikkeling. In die LRJG-praktijk met eigen tradities, idealen en overtuigingen wordt PAZIO geïntroduceerd.

\subsection{EERSTE PAZIO-IMPLEMENTATIE POGING BIJ LRJG-PARKWIJK}

In januari 2010, zo'n anderhalf jaar voor de hierboven beschreven demonstratie van PAZIO, was met PAZIO een eerste implementatiepoging ondernomen bij de Leidsche Rijn Julius Gezondheidscentra, namelijk bij locatie Parkwijk. Daar werd begonnen met een pilot-implementatie van PAZIO.

Eind 2009 is PAZIO wat de ontwikkelaars betreft gereed om te implementeren in de zorgpraktijk van het eerstelijns gezondheidscentrum de Leidsche Rijn Julius Gezondheidscentra. M. Dekker werd door het projectmanagement van PAZIO aangesteld als implementatiemanager. PAZIO wordt technisch geïmplementeerd en vanaf januari 2010 begint men met de implementatie van het gezondheidsportaal in de zorgpraktijk van de huisartsen en hun collega's. Voor deze pilot-implementatie wordt een jaar uitgetrokken. Er wordt gekozen om de implementatie te starten op een van de op dat moment vier LRJG-locaties, namelijk op de locatie Parkwijk.

Helaas mislukt de implementatie. PAZIO wordt geen onderdeel van de werkprocessen in de zorgpraktijk in Parkwijk. Dit is goed te begrijpen vanuit de situatie bij LRJG en de gebreken van PAZIO op dat moment. LRJG was net langs het randje van faillissement gegaan. De interimmanager Hoefsmid had de organisatie financieel weer op de rit gekregen, 
maar dat was het personeel niet in de koude kleren gaan zitten. De medewerkers zijn nog niet in de stemming om een nieuw project op te pakken, maar hebben behoefte aan rust en stabiliteit en allerminst aan meer verandering of nieuwe innovatieprojecten. Daarnaast blijkt dat de meerwaarde van PAZIO voor de zorgverleners nog minimaal is. PAZIO blijkt lastig in het gebruik en levert de zorgverleners extra werk op. Die situatie zorgt ervoor dat men vooral op zoek gaat naar redenen om PAZIO niet te implementeren. Het personeel maakt optimaal gebruik van haar hindermacht en PAZIO geeft daartoe genoeg aanknopingspunten.

Voor de pilot implementatie wordt een uitgebreid Plan van Aanpak geschreven. ${ }^{291}$ Er worden handleidingen en communicatieplannen geschreven. De zorgverleners worden geïnstrueerd, gebruikers werden geworven, geregistreerd en kregen een account. Een helpdesk wordt opgezet voor ondersteuning. ${ }^{292}$ Wat echter opvalt is dat er in het plan geen ruimte is opgenomen voor het ontwikkelen van de procedures en werkprocessen, die in de demonstratiebijeenkomst die hierboven beschreven werd, zo essentieel werden beschouwd.

De werkprocessen en procedures zijn essentieel voor de zorgverleners. Ze vragen daar dan ook meteen naar als de implementatiepilot in januari van 2010 in de praktijk van LRJG start. Op dat moment bepalen ze naast de agenda ook de sfeer, dat is goed zichtbaar in een van de eerste e-mailberichten die verstuurd wordt na de start van de pilot implementatie. Wind, huisarts bij LRJG stuurt een e-mail aan M. Dekker en stuurt deze meteen cc naar de directeur van LRJG Oomes en de hoofdassistente Roemer.

'Beste M.,

Vorige week kwam er een dame van PAZIO haar naam is me even ontschoten) uitleg geven over het e-Consult. Omdat wij als huisartsen en assistenten eigenlijk amper op de hoogte zijn van wat dit precies inhoudt, bestookten we haar met allerlei vragen en opmerkingen waar ze eigenlijk geen antwoord op had en weinig mee kon. Ze adviseerde ons contact met jou op te nemen en onze vragen/opmerkingen bij jou neer te leggen. Bij deze. ${ }^{293}$

De toon van de mail van Wind is kritisch: er zijn allerlei vragen en geen antwoorden. De ondertoon is dat er een valse start is gemaakt met 
de pilot. Huisartsen en assistenten moeten klaarblijkelijk iets met een e-Consult, dat op dat moment de kernapplicatie binnen PAZIO is, maar weten nog nauwelijks ergens van en krijgen geen antwoord op hun vragen. De professionals in het zorgcentrum voelen zich onvoldoende serieus genomen bij de start van deze implementatie.

De mail van Wind bevat een lijst van zeven vragen en opmerkingen. Geen van die vragen gaan over de techniek. Naast enkele financieringsvragen (hoeveel krijgen we voor een e-Consult?) gaat het met name over werkprocessen en de uitwerking daarvan met PAZIO. Er een belangrijke constatering is:

'dat eConsult niet gekoppeld is aan Medicom. Dit maakt het eigenlijk onwerkbaar omdat daarna alles nog opnieuw moet worden ingevoerd in Medicom, dit kost veel tijd. Op welke termijn kunnen we de koppeling aan Medicom verwachten?'294

Medicom is het huisarts informatiesysteem (HIS) dat binnen LRJG gebruikt wordt. In dat systeem zitten alle patiëntengegevens en dossiers. Het HIS is onderdeel van vrijwel alle werkprocessen in het gezondheidscentrum. Werkprocessen en systemen die niet integreren met het HIS zijn op zijn minst onhandig, maken het werken soms vrijwel onmogelijk en krijgen dan ook vanzelfsprekend niet de sympathie van de zorgverleners. PAZIO levert hen op deze manier immers extra werk en gedoe op.

Een week later is er een overleg met de zorgverleners van LRJG. Projectleider M. Dekker erkent het belang van de procedures direct en doet een concreet voorstel voor de werkprocessen voor het eConsult en zal dat voorstel later per mail rondsturen. De zorgverleners blijven de nodige vragen en opmerkingen maken bij het werkproces voor het eConsult, zonder daarbij actief bij te dragen aan de oplossing. PAZIO, en specifiek M. Dekker, wordt geacht de gestelde vragen en genoemde problemen op te lossen. Door deze rolverdeling wordt het werkproces niet een proces van de zorgverleners van LRJG, maar het proces van PAZIO voor LRJG. Dat geeft de zorgverleners zo de ruimte om kritische vragen en opmerkingen te blijven plaatsen, ontevreden te blijven over het resultaat en vooral ook om afstand te houden van het gebruik van PAZIO in de LRJG-praktijk. Dat wordt versterkt doordat duidelijk wordt dat de integratie van PAZIO met het HIS voorlopig niet realiseerbaar is. PAZIO wordt daarmee als een onvoldoende werkend systeem beschouwd. Het is wat LRJG betreft een legitieme reden om PAZIO nog niet te gaan gebruiken. 
In het voorjaar van 2010 blijkt dat ook de als eerste testgebruikers uitgenodigde patiënten PAZIO niet of nauwelijks gebruiken. Roemer meldt:

'aangemelde patiënten [hebben] blijkbaar niet de behoefte om het hun huisarts te mailen. Of er moet actiever door de huisarts intake gedaan worden bij de patiënten die op dat moment ook een behandelrelatie hebben. Ik de indruk heb dat de aanmeldprocedure nogal complex is?! en mensen de moeite liever niet nemen. Want zelfs de mensen die ik actief benaderd heb, melden zich niet aan. ${ }^{295}$

Naast de zorgverleners lijken dus ook de patiënten nog niet enthousiast over PAZIO. De procedures lijken voor hen nog te complex waardoor PAZIO niet genoeg meerwaarde biedt.

Het PAZIO-management is ondertussen op haar beurt ook niet gelukkig met de voortgang van de implementatie van PAZIO bij LRJG. Op donderdag 17 juni krijg ik, direct na de stuurgroepvergadering die dag, het volgende e-mailbericht van De Lange.

Hoi Michiel,

Vandaag is Oomes redelijk onder druk gezet om meer te doen om het gebruik van PAZIO te bevorderen. Uiteraard gaan we hem hierbij helpen. Onderstaande is 1 van de acties die hieruit voortvloeien.

\section{Groeten $^{296}$}

Het PAZIO-management is al enige tijd ontevreden over de inzet van LRJG voor PAZIO. In de overall programma-opzet is de afspraak gemaakt dat LRJG in de pilot vijfhonderd patiënten zou includeren in PAZIO. Daar is op dit moment nog allerminst sprake van. En waar het LRJG-management er iedere keer in de stuurgroep en daarbuiten op hamert dat PAZIO onvoldoende werkt omdat ze niet integreert met het huisarts informatiesysteem, zo hamert het PAZIO-management erop dat LRJG zich onvoldoende inzet voor PAZIO en nog steeds ver af is van de beloofde inclusie van vijfhonderd patiënten. Dat beide problemen met elkaar samenhangen blijkt moeilijk bespreekbaar. Er wordt vooral in termen van verplichtingen en het in gebreke blijven gesproken. Het resultaat is dat de samenwerkingsrelatie onder druk komt te staan. 


\subsection{EVALUATIE VAN DE EERSTE PAZIO-IMPLEMENTATIE POGING}

M. Dekker moet om redenen die buiten het project liggen haar implementatiewerkzaamheden neerleggen. Het PAZIO-management vraagt mij als projectmedewerker om de implementatie van PAZIO bij LRJG van haar over te nemen. Dat biedt de mogelijkheid om te werken aan een nieuwe start met de betrokken, maar gebrouilleerde partijen. Ik spreek uitgebreid met M. Dekker om haar ervaringen te horen en haar perspectief op de zaken te krijgen en ik maak kennis met de LRJGzorgverleners en bestuurders. Sinds maart ben ik onderdeel van het PAZIO-team en weet goed wat daar speelt. In overleg met Verkerk besluit ik op basis van mijn observaties en gesprekken een evaluatieve analyse te maken van de huidige meerwaarde van de verschillende onderdelen van PAZIO voor de verschillende stakeholders. Ik vat dat samen in een 'stoplichtmatrix' waar met rood, oranje en groen aangeven wordt wat de effectieve meerwaarde of belasting van PAZIO is voor iedere stakeholder (zie figuur 4.1). Het blijkt dat er veel seinen op rood staan. PAZIO is op dat moment vooral een extra belasting voor de zorgverleners en nog lang niet de beloofde vrijheidsmachine voor de patiënten.

\begin{tabular}{|c|c|c|c|c|c|c|c|c|c|}
\hline & eConsult & eRecept & eAfspraak & DKZ/ZM & R.Online & Content & COPD & Hartfalen & Preventie \\
\hline Patiënt & + & + & - & - & - & - & - & - & - \\
\hline Huisarts & + & + & - & + & + & - & - & - & - \\
\hline Assistent(e) & + & + & - & + & - & - & - & - & - \\
\hline $\mathrm{POH}$ & + & + & - & + & - & - & - & - & - \\
\hline
\end{tabular}

+ : beschikbaar

extra werk

- : niet beschikbaar

oranje: geen meerwaarde

groen: meerwaarde

FIGUUR 4.1. Stoplichtmatrix uit de evaluatie van de PAZIO-implementatie bij LRJG. ${ }^{297}$ 
In de evaluatie ${ }^{298}$ wordt melding gemaakt van de vrijwel verdwenen betrokkenheid bij de LRJG-medewerkers met betrekking tot PAZIO. De resultaten van de pilot tot nu toe zijn nog niet om over naar huis te schrijven.

'Het is nog niet gelukt PAZIO-onderdeel van de LRJG-praktijk te maken. PAZIO wordt nog nauwelijks gebruikt door artsen en patiënten. Tot nu toe zijn er slechts twee e-Consulten geweest en staan er negen patiënten op actief. Er zijn overigens ook zo'n 120 patiënten die zich spontaan voor PAZIO aangemeld hebben, maar nog niet geactiveerd zijn door het LRJG.' ${ }^{299}$

Als reden voor de stokkende implementatie wordt het volgende opgevoerd:

'In deze pilotfase is het nog niet mogelijk gebleken om een variëteit aan goed functionerende eHealth applicaties aan te sluiten op PAZIO. In de praktijk is het vooralsnog alleen mogelijk om eConsult, eRecept en diabetesketenzorg te gebruiken. Deze applicaties werken echter nog niet optimaal. Het eConsult wordt nog niet automatisch in het HIS van de arts verwerkt, maar vraagt met enige regelmaat extra knip-en-plak werk. eRecept vraagt om een eigen medicijnselectie uit het gehele aanbod op de apothekerssite door de patiënt zelf, in plaats van dat de patiënt de medicijnen eenvoudig kan selecteren uit een lijst van door hem/haar eerder gebruikte medicijnen. Diabetesketenzorg is wel beschikbaar voor de zorgverlener maar het zelfmanagementdeel is nog niet opengesteld voor de patiënt en de koppeling met het HIS werkt niet optimaal.' ${ }^{300}$

Interessant genoeg wordt de nadruk hier gelegd op de kwaliteit van de applicaties. Die zou onvoldoende zijn voor goed gebruik. Geconcludeerd wordt dat gezocht moet worden naar een killer-applicatie die meerwaarde biedt en eenvoudig bruikbaar is. Zowel probleem als oplossing worden daarmee gereduceerd tot een technische kwestie. De noodzaak van werkprocessen, zoals die in de demonstratie werden benoemd, en waarin techniek en praktijk met elkaar verweven raken, blijft ook hier onbenoemd. ${ }^{301}$ 
De evaluatie heeft desondanks een grote impact op de pilot-implementatie bij LRJG. De frustraties en problemen van de stakeholders worden hier expliciet benoemd en gekaderd. Het wordt daarmee voor alle betrokkenen duidelijk, maar ook begrijpelijk dat LRJG achterblijft in haar belofte om PAZIO te integreren in haar bedrijfsvoering en in dat kader snel vijfhonderd patiënten in PAZIO te includeren. Ook wordt duidelijk dat PAZIO eveneens haar gedane beloften nog niet inlost. PAZIO biedt nog onvoldoende meerwaarde voor de LRJG-praktijk. De evaluatie geeft een basis om met elkaar in gesprek te gaan en zo te komen tot gezamenlijk gedragen oplossingsrichtingen.

\subsection{REVITALISERING VAN DE PAZIO- IMPLEMENTATIE BIJ LRJG}

\subsubsection{BEGINNEN BIJ HET LRJG-MANAGEMENT}

Als kersverse implementatiemanager ga ik op dinsdag 15 juni 2010 als eerste in gesprek met De Wit, de medisch directeur van LRJG ${ }^{302} \mathrm{Hij}$ is weliswaar kritisch op de werkzaamheid en het gebruikersgemak van PAZIO, maar tegelijkertijd weerhoudt hem dat er niet van om ook flinke verwachtingen van en ambities met PAZIO te hebben. De Wit vertelt hoe hij met PAZIO mogelijkheden ziet om te zorgen voor nieuwe toegang en nieuwe grenzen van de zorg. Hij vindt PAZIO belangrijk omdat ze inhoudelijke zorgvernieuwing ondersteunt. PAZIO moet een elektronische schil rondom de praktijk vormen en zo een continuüm vormen tussen de nuldelijn (zelfzorg door de patiënt en zijn naasten) en de eerstelijnszorg in het gezondheidscentrum. Met PAZIO hoopt De Wit ook buiten de praktijklocatie zorg aan te kunnen bieden. Zijn verwachting is dat een patiënt met PAZIO bijvoorbeeld eenvoudig betrouwbare informatie over ziekte en gezondheid kan vinden. Via PAZIO kunnen patiënten laagdrempelig online afspraken maken en online consulten hebben met een zorgverlener. Volgens De Wit kunnen bestaande zorgprocessen zo worden aangevuld of gesubstitueerd en de LRJG-zorg verplaatst zich tot buiten de muren van het gezondheidscentrum. Met PAZIO zouden ook zaken naar de eerste lijn getrokken kunnen worden. De Wit denkt daarbij aan preventie. Preventie is vooralsnog vooral een zaak van GGD's en volksgezondheid en geen vanzelfsprekend onderdeel van de eerstelijnszorg voor patiënten. Met het online preventiekompas kan LRJG zich via PAZIO richten op persoonlijke preventie voor haar patiënten. 
Om de verwachtingen waar te maken moet PAZIO wel verder ontwikkeld en gevuld worden, volgens De Wit. Vooralsnog vindt hij PAZIO nog vrij leeg. Hij voert al wel gesprekken over geestelijke gezondheidszorg online met het Trimbos Instituut en Indigo (GGZ-instelling). Het Trimbos Instituut heeft het digitale programma Grip op je dip ontwikkelt voor mensen met milde depressiviteitsklachten. Er wordt gewerkt aan de inzet van de zelfmanagementtool voor diabetes van VitalHealth Software en het NIPED heeft een programma voor cardiovasculair risicomanagement. Daarnaast is het Nederlands Huisarts Genootschap bezig haar patiënten informatie digitaal aan te bieden. Volgens De Wit zijn er dan ook kansen genoeg voor PAZIO en LRJG.

Ik suggereer dat eAfspraak wellicht een interessante optie is om mee te starten. Daarmee kunnen patiënten zelf online afspraken met de zorgverleners inplannen en worden de assistenten minder belast met bellers voor afspraken. De Wit ziet dat alleen voor zich als de patiënt een verzoek indient en de assistente deze vervolgens inplant. Zelf inplannen lijkt hem geen optie, dan zou er geen triage zijn. Het kan misschien voor de $\mathrm{POH}$ en zaken als wratten of uitstrijkjes, maar niet voor de huisartsen. Daar is triage voor nodig om te bepalen wat de duur, het tijdstip, de urgentie is van de te maken afspraak en met welke medewerker. Triage is volgens De Wit een vorm van onderhandelen. Hij beschrijft hoe dat gaat:

'De assistente vraagt de patiënt: "waar gaat het over?”. De patiënt geeft aan dat liever met de arts zelf te bespreken. "Ik heb een plekje voor volgende week vrijdag voor u." "Dat is te laat", zegt de patiënt. "Dan moet u me toch vertellen waar het over gaat.", zegt de assistent.' ${ }^{303}$

De patiënt krijgt de mogelijkheid de arts te kiezen, dan bepaalt de assistente het tijdstip. De patiënt mag ook het tijdstip bepalen, dan bepaalt de assistente bij welke arts. Deze procedure is voor De Wit vooralsnog onaantastbaar.

Het eConsult sluit wat De Wit betreft beter aan bij de bestaande praktijk. Het kan voor een aanzienlijk deel het telefonisch spreekuur vervangen. Het gaat om substitutie van werkzaamheden, niet om iets dat buiten de taakomschrijving valt. De artsen hebben twee keer per dag een half uur telefonisch spreekuur. Zoals de assistenten de telefoontjes doorzetten, kunnen ze ook de binnengekomen eConsults naar de artsen doorzetten. De ICPC-codering ${ }^{304}$ en de administratie moet dan wel gewoon via het 
HIS kunnen lopen. Voorwaarde voor vrijwel elke toepassing in PAZIO is voor De Wit dat de HIS-koppeling probleemloos is. Er moeten geen dubbele registratie- of administratieprocessen ontstaan.

We concluderen dat we in ieder geval de draad weer op moeten pakken en een plan moeten maken en een nieuwe fase in de uitrol van PAZIO moeten ingaan. Op dit moment is er veel onduidelijkheid rond PAZIO, dat moeten we doorbreken en aan de gang gaan. Om de PAZIO-implementatie bij LRJG vlot te trekken spreken we af dat ik een nieuw plan van aanpak maak. Hierin worden de gedeelde ambities en de verwachtingen over en weer geëxpliciteerd en een roadmap voor realisatie uitgestippeld. Dit plan en deze roadmap worden bekend onder de naam revitaliseringsplan PAZIO@LRJG. Het wordt in de praktijk het onderhandelingsdocument tussen PAZIO en LRJG. Dat betekent dat er veel versies het licht zien en er gedetailleerd wordt gelezen, vooral als het gaat om de afspraken rond inzet en resultaatverplichtingen van de beide organisaties. Pas maanden later, op 27 mei 2011, worden de documenten goedgekeurd tijdens de in de opening van dit hoofdstuk beschreven formele bijeenkomst onder leiding van stuurgroep voorzitter Kuilboer.

Tijdens mijn overleg met De Wit stel ik voor dat ik allereerst met de centrummanagers van de vier LRJG-locaties ga praten over PAZIO. Wat doen ze er mee, welke vragen en ambities hebben ze met PAZIO? Daarnaast zal ik het belang van de koppeling tussen HIS en PAZIO voor LRJG onder de aandacht van het PAZIO-management brengen. Verder geef ik aan dat het belangrijk is dat er iemand binnen LRJG het gezicht en aanspreekpunt van PAZIO te laten zijn. Daarmee wordt PAZIO ook iets van LRJG en kunnen vragen, problemen en ideeën gekanaliseerd worden. De Wit herkent het belang daarvan en doet meteen een paar suggesties voor medewerkers die dat zouden kunnen worden.

Op dinsdag 6 juli 2010 makk ik kennis met Oomes, de directeur van de LRJG. ${ }^{305}$ Hij begint met me te vertellen dat de content van PAZIO nog erg mager is. Daarnaast lopen de zorgverleners tegen problemen aan: het aanmelden gaat niet goed en doordat de koppeling met het HIS ontbreekt, moeten de huisartsen dubbel werk doen. Hij zou graag zien dat ik deze problemen oplos en daarnaast een plan van aanpak maak voor de uitrol van PAZIO. Ik geef aan dat ik daar graag mijn best voor doe en vraag met wie van LRJG ik daaraan kan samenwerken. PAZIO moet immers onderdeel worden van de werkprocessen van LRJG en daar gedragen worden. Daar kan ik van buitenaf maar ten dele aan bijdragen. Inzet en input van LRJG is noodzakelijk. ${ }^{306}$ 
Nadat ik bij Oomes geweest ben maak ik kennis met Schuurman, de ICT-beheerder bij LRJG. ${ }^{307}$ Ik vertel hem over de geschiedenis, problemen en ambities met PAZIO binnen LRJG. Hij vertelt me dat hij verbaasd was dat er zoiets bij LRJG nog niet was. Bij het gezondheidscentrum in Almere waar hij patiënt is, is het al lang mogelijk online afspraken te maken en via eConsult contact met je zorgverlener te hebben. Het is iets dat bij deze tijd past. Schuurman geeft ook een inkijkje in de ICT status van LRJG. De werkstations zijn verouderd, de 15 inch schermen hebben een te lage resolutie voor moderne toepassingen en de stations worden zwaarder belast dan ze aankunnen. De toepassingen krijgen vaak de schuld van de LRJG-ers, maar veel problemen worden veroorzaakt door de systemen van LRJG zelf. Daarnaast is de internetverbinding onvoldoende, zeker in Vleuterweide. De internetverbinding loopt via een DNS-kastje van PharmaPartners. Als er problemen zijn bij PharmaPartners dan heeft het LRJG niet alleen geen toegang tot het HIS maar ook niet tot het internet. Schuurman heeft met afgesproken Oomes dat ze er de komende tijd aan werken om de ICT-infrastructuur weer bij de tijd te brengen.

\subsubsection{BEZOEKEN VAN DE LRJG-LOCATIES}

Nadat ik het LRJG-management gesproken heb, ga ik langs bij de vier locaties van LRJG om daar over de ervaringen en reacties van de zorgverleners te horen en te inventariseren wat de problemen en aandachtspunten zijn voor het implementatietraject. M. Dekker heeft ooit de eerste issuelist gemaakt, die heb ik van haar overgenomen. De lijst is gevuld met aandachtspunten voor de PAZIO-implementatie. Ik vul deze lijst aan op mijn ronde langs de LRJG-locaties.

Roemer, hoofdassistente in Terwijde, laat zien hoe ze in PAZIO patiënten aanmeldt en demonstreert meteen hoe onoverzichtelijk PAZIO is en hoe lastig de redactiepagina's werken. Er zijn om te beginnen twee onbegrijpelijke wachtwoorden nodig om in te loggen: de eerste betreft de zorgverlenerskant van PAZIO en de tweede de redactie-omgeving. Die wachtwoorden zijn niet te wijzigen en er is geen gebruiksaanwijzing beschikbaar. Waarbij Roemer verzucht: 'als het dan niet werkt, dan laat je het verder liggen'. Als hoofdassistente krijgt ze ook alle eConsult-berichten van alle LRJG-locaties te zien. Dat is onhandig en onoverzichtelijk. ${ }^{308}$

Twee dagen later spreek ik huisarts Van den Brekel, ook werkzaam op locatie Terwijde. Zij heeft een eigen issuelijst gemaakt, waarop problemen 
en vragen zijn verzameld. Op die lijst staan zaken waarover afspraken gemaakt moeten worden binnen LRJG: over de streaming van de eConsults, over een disclaimer, over categorieën met onderwerpen en aantal karakters dat beschikbaar is voor een eConsult, over omgangsvormen in het eConsult. ${ }^{309}$

Als ik op 19 augustus 2010 Smits en Meijer van LRJG Parkwijk spreek hoor ik vooral over de mislukte PAZIO-implementatie in Parkwijk van begin dit jaar. ${ }^{310}$ Smits vertelt dat PAZIO met veel bombarie werd geïntroduceerd, dat zij er zelfs er nog mee op de lokale tv gekomen is, maar dat het technisch allemaal niet werkte. Zij werd daar vervolgens door patiënten op aangesproken. Meijer vertelt dat er zestien mensen zich hebben aangemeld, maar dat geen van hen door LRJG is geautoriseerd. Ze heeft zelf één keer met PAZIO geoefend en haar collega's nog helemaal niet. Het is allemaal weggezakt.

Als ik me een paar dagen later, op 6 september 2010, meld in de LRJG-praktijk in Vleuterweide vrees ik opnieuw een gesprek met klachten, problemen en verwijten. Niets is minder waar. Huisarts en praktijkmanager Hollander begint meteen met een pleidooi om PAZIO nu als eerste in Vleuterweide te implementeren. Vleuterweide is prone vertelt Hollander en ze heeft vanochtend in het centraal managementoverleg van alle LRJG-locaties al over PAZIO in Vleuterweide gesproken. Vleuterweide heeft nog 0,5 fte over, terwijl de andere locaties overbezet zijn. Er is hier ruimte en energie voor iets nieuws. Daarbij heeft Vleuterweide een relatief hoogopgeleid patiëntenbestand en die staan volgens Hollander meer open voor digitale dienstverlening. Vleuterweide kan zich met PAZIO ook onderscheiden van het concurrerende huisartsencentrum op de verdieping boven hen in hetzelfde gebouw.

Hollander wil graag aan de gang met eAfspraak. Dat kan de assistent en de telefoondruk verlichten. Ik vertel dat dat consequenties kan hebben voor de triageprocedures en het agendamanagement. Dat is geen probleem. Huisarts Straal geeft aan dat triage alleen ter voorbereiding is van de zorgverlener en niet om te beoordelen of een afspraak gemaakt moet worden. Er is altijd plek, de patiënt bepaalt of hij of zij wil komen. Dus als je in eAfspraak aangeeft waarvoor je komt, is dat voldoende.

Hollander vindt het van belang patiënten te betrekken bij het implementatieproces. Ik ben aangenaam verrast. Hollander is de eerste binnen LRJG die met mij spreekt over een rol voor patiënten 
in het implementatieproces van PAZIO. ${ }^{311}$ Ook in het PAZIO-team is er in die fase vrijwel geen aandacht voor een rol voor de patiënt in het implementatietraject. Ik stel voor om feedback te generen door patiënten te bezoeken en PAZIO met hen te testen en te bespreken. Hollander had daar zelf nog niet gedacht, maar staat er enthousiast voor open. We spreken af dat Hollander het idee voor een PAZIO-pilot in Vleuterweide binnen LRJG bepreekt en dat ik het voorleg aan het PAZIO-management. Ik vraag of we nog rekening moeten houden met concurrentiegevoelens tussen de praktijken. Dat wuiven Hollander en Straal weg. De andere locaties zijn al lang blij als wij hun boontjes doppen. Ze melden wel dat het fijn is dat Roemer, die nu nog hoofdassistente in Terwijde is, per november-december in Vleuterweide komt werken. Vanaf dat moment is er pas echt ruimte om met PAZIO te beginnen. De Lange van het PAZIOmanagement reageert opgetogen als ik hem vertel over het enthousiasme in Vleuterweide. Hij geeft aan dat we dat met twee handen moeten aanpakken. ${ }^{312}$

\subsubsection{REVITALISERINGSBIJEENKOMST PAZIO@LRJG}

Op 27 september is er een zogenaamde

revitaliseringbijeenkomst voor de huisartsen van de verschillende locaties om PAZIO binnen LRJG nieuw leven in te blazen. ${ }^{313}$ Onder andere Straal, De Wit, Hollander en Smits zijn aanwezig. Van Gelder van PharmaPartners presenteert de optie om via PAZIO in te loggen bij Mijngezondheid.net (MGn). MGn is het portaal van PharmaPartners, de leverancier van huisartsinformatiesysteem Medicom. MGn is, anders dan PAZIO, volledig geïntegreerd met Medicom. Voor de zorgverlener vormen MGn en Medicom één systeem. eConsult-berichtenverkeer wordt direct opgeslagen in het dossier van de betreffende patiënt in Medicom, eAfspraken zijn direct gekoppeld aan de zorgverlenersagenda's in Medicom en herhaalrecepten worden direct gearchiveerd. PAZIO ontbeert zo'n koppeling met Medicom. Maar PharmaPartners biedt nu aan om vanuit PAZIO door te koppelen naar MGn en zo ook vanuit PAZIO de koppeling te leggen met het HIS. Functioneel is PAZIO eigenlijk overbodig, MGn kan alles wat PAZIO kan ook zelf. PAZIO is echter onafhankelijk van leveranciers en dat houdt de zorgverlener flexibel. Een gezondheidscentrum kan zonder de patiënt lastig te vallen 
van HIS wisselen. Daarnaast biedt PAZIO anders dan MGn voor de patiënt de mogelijkheid om via een portaal een digitale verbinding te leggen met ook andere zorgverleners buiten LRJG. PAZIO kan in principe de zorg- en behandelrelaties die een patiënt heeft in één portaal integreren.

Tijdens de demonstratie van MGn zijn de zorgverleners er vooral op gespitst hoe het systeem in werkprocessen past en in te regelen is. Ze stellen werkproces-gerelateerde vragen: bij wie komt het eConsult binnen, hoe werkt een eConsult als je op basis van de patiënt nog aanvullende vragen hebt, hoe worden berichten geregistreerd? De fundamentele keuze om een nieuw portaalsysteem te introduceren en aan PAZIO te koppelen, blijft vrijwel onbesproken. De werkbaarheid en het gemak van inpassing in de werkprocessen zijn bepalend. Het lijkt de zorgverleners begrijpelijkerwijs weinig te interesseren hoe het technisch werkt of hoe het er op hun website uit ziet, áls het maar werkt. De zorgverleners tonen weinig gevoel voor de technologie, blijkt uit opmerkingen als 'zitten we nu in PAZIO?' of 'moeten we nu steeds in het systeem kijken of er eConsulten binnen gekomen zijn? ${ }^{314}$ De werkproces-gerelateerde vragen beantwoordt Van Gelder met het mantra dat alles is in te regelen en MGn flexibel is. Het blijft onbesproken wát er dan precies in te regelen is, wát er flexibel is. Ook blijft onbesproken hoeveel tijd, geld en energie deze flexibiliteit en inregeling gaat kosten. De zorgverleners krijgen een beloftevolle technological fix als oplossing voor hun praktische problemen gepresenteerd en gaan graag in die belofte mee.

Als ik in november De Wit weer spreek, verzucht hij dat de nog ontbrekende HIS-koppeling het werken met PAZIO er niet eenvoudiger op gaat maken. Hij stelt dat LRJG daarom ook niet verantwoordelijk kan worden gemaakt voor de inclusie van vijfhonderd patiënten. Er moet een extra inspanning door PAZIO gedaan worden in verband met de HISkoppeling. Als het niet werkt dan stapt LRJG eruit, stelt De Wit. ${ }^{315}$

We belanden daarmee opnieuw in een wij-zij schema. LRJG vindt dat de techniek niet werkt en dat ze dus niet verantwoordelijk kan zijn voor de inclusie van patiënten. PAZIO stelt dat LRJG zich aan de afspraken moet houden en al lang vijfhonderd patiënten geïncludeerd had moeten hebben: innoveren is pionieren en daar horen nu eenmaal hobbels bij. Opvallend is dat De Wit naast de voorliggende problemen ook kansen met PAZIO ziet. Er is flinke frustratie over de HIS-koppeling in de praktijk, maar De Wit heeft tegelijkertijd ook grote vergezichten over de impact van technologie op die praktijk. Hij wil PAZIO vullen met nieuwe modu- 
les en content. Voor de procesmatige en organisatorische aanpassingen die dat vraagt van LRJG is echter zowel bij het PAZIO-management als bij de LRJG-projectleiding weinig oog. De implementatie wordt gezien als een uitvoerende praktische klus en allerminst als een ontwerpopgave voor de procedures en werkprocessen in de praktijk..$^{316}$

\subsubsection{DE HIS-INTEGRATIE KOMT ER NIET}

In overleg met de LRJG-directie wordt besloten de pilot bij LRJG Parkwijk niet te herstarten. Het is beter opnieuw te beginnen dan te proberen de valse start in Parkwijk recht te zetten. De locatie Terwijde is het op dit moment te druk met andere activiteiten, daarom wordt voor Vleuterweide gekozen. Dit is ook de locatie waar De Wit als huisarts praktijk houdt, waardoor de lijnen op alle niveaus kort blijven. De Wit heeft Straal, huisarts bij LRJG-Vleuterweide, gesproken. Zij neemt als huisarts zitting in de werkgroep, Roemer doet dat als hoofdassistente. Verder neemt Schuurman, de ICT-beheerder bij LRJG, zitting in de werkgroep, naast ikzelf namens PAZIO en De Wit vanuit het LRJG-management.

De Wit noemt opnieuw dat de HIS-integratie een voorwaarde is voor de revitalisering. PAZIO en LRJG hebben ondertussen maanden gesproken over de noodzaak en problemen met de HIS-integratie. Als tussenpersoon heb ik veel van die gesprekken bijgewoond. Het blijkt niet eenvoudig uit de impasse te komen. Ik heb het probleem regelmatig besproken met Van der Tas, een ervaren verandermanager en de sparringpartner die mij de kneepjes van het verandermanagement bijbrengt. ${ }^{317}$ We komen eropuit dat ik de impasse mogelijk kan doorbreken door helder te zijn zowel naar PAZIO als LRJG. Na een voorbespreking met het PAZIO-team vertel ik De Wit onomwonden: 'De HIS-koppeling gaat er het komend jaar niet komen.' ${ }^{118} \mathrm{Dan}$ ben ik stil en wacht wat er gaat komen. Tot mijn verbazing reageert De Wit kalm en gelaten. Geen onderhandeling of schuldvraag dit keer, maar acceptatie. Ik leg uit dat PharmaPartners een prijs van €300.000 hangt aan de optie die ze presenteerde tijdens de revitaliseringsbijeenkomst, dat is ver buiten wat er financieel reëel of mogelijk is. Daarnaast stelt PharmaPartners hoge veiligheidseisen, waardoor de patiënt na inloggen bij PAZIO via DigiD nogmaals moet authentiseren voor het eConsult. Aan een oplossing voor die dubbele inlog wordt wel gewerkt, maar die is er niet voor medio 2011. De Wit stelt voor dat de koppeling dan in 2011 gerealiseerd wordt en dat we anders opnieuw om tafel gaan om ons te bezinnen op de situatie. Dat lijkt me een prima idee. Ik 
bied aan dat we dan met Pharmeon, de huidige eConsult leverancier gaan kijken hoe we de werkprocessen, gegeven de situatie, kunnen optimaliseren.

Vervolgens gaan we over tot de orde van de dag. We bespreken het concept-revitaliseringsplan met daarin een lijst van te ontwikkelen en in PAZIO te integreren modules en links. De Wit stelt voor dat we half december een brief aan alle LRJG-Vleuterweide patiënten sturen waarin we PAZIO presenteren en hen uitnodigen daarvan gebruik te maken. Vervolgens kunnen we ieder kwartaal een LRJG-locatie toevoegen. De Wit vraagt of ik de afspraken wil uitwerken in een bijlage bij het revitaliseringsplan. Daarnaast kan het PAZIO@LRJG-team, zoals ik het doop, in Vleuterweide van start.

We nemen in een positieve sfeer afscheid. De problemen zijn aangekaart, de lucht is geklaard, opgelucht stap ik naar buiten. ${ }^{319} \mathrm{Ik}$ kijk uit naar de reactie van het PAZIO-management op deze doorbraak. Die is minder enthousiast dan ik hoopte. Voor hen is de oplossing uit de impasse weliswaar van belang, maar het is tegelijkertijd een erkenning van hun falen om de HIS-integratie tot stand te brengen.

\subsection{TWEEDE PAZIO-IMPLEMENTATIE POGING BIJ LRJG-VLEUTERWEIDE}

\subsubsection{DE HUISARTS}

Op 9 december 2010 maken Straal en ik kennis. Straal is huisarts en De Wit heeft me naar haar verwezen als de PAZIO-projectleider bij LRJG-Vleuterweide. Ik ben benieuwd hoe zij tegen het project en haar nieuwe rol aan kijkt. Straal vertelt me dat De Wit haar gevraagd heeft mee te denken over PAZIO, maar ze had er geen idee van dat ze tot projectleider is benoemd. Ze heeft ook geen gelegenheid gehad de stukken te lezen. Bij het mailtje dat ze van De Wit kreeg, zat wel de issuelist. Straal is enthousiast over PAZIO. Ze heeft in de praktijk waar ze eerder werkte al met eConsults gewerkt. Ondanks dat ze zichzelf nog steeds een digibeet vindt, vond ze dat toentertijd al leuk en iets dat hoort bij deze tijd. Jaren geleden heeft ze al eens meegedacht over PAZIO, maar er daarna nooit meer iets van gehoord en nu is ze tot haar verrassing benoemd als projectleider. Ik vertel Straal dat ik als implementatiebegeleider haar graag vanuit PAZIO ondersteun en dat de uitdaging is om PAZIO en LRJG een werkende eenheid te laten vormen. De werkprocessen in de LRJG-prak- 
tijken en PAZIO moeten geïntegreerd worden. In het revitaliseringplan spreek ik daarom ook van PAZIO@LRJG. Met het projectteam borduren we daarop voort door het team in Vleuterweide PAZIO@LRJG.VW te noemen.

Straal reageert teleurgesteld als ik haar vertel dat de HIS-PAZIO-koppeling er voorlopig niet komt. Het HIS staat centraal in de praktijk, vertelt ze en ze laat het meteen zien. Ze opent haar agenda in het HIS, waar de assistenten alle consulten en afspraken in zetten. Ze klikt door naar de betreffende patiëntendossiers en de labuitslagen. De Saltro-labuitslagen en specialistenbrieven worden direct gekoppeld aan de betreffende patiënt. Vanuit Zorgdomein kun je direct verwijsbrieven koppelen en versturen naar specialisten. Voor een eConsult zou het ook fijn zijn als dat zo geïntegreerd was. Je krijgt als zorgverlener immers maar vijf minuten voor het beantwoorden van een eConsult, dan neemt even knippen en plakken als snel een aanzienlijk deel van de beschikbare tijd in beslag. Het is kortom belangrijk dat de zaken die we implementeren zo min mogelijk tijdsverlies en inspanning vragen. Het ontbrekende HIS-integratie is in dat kader een serieus praktisch probleem..$^{320}$

Straal is gecharmeerd van de mogelijkheid om een eAfspraak te maken. Daarmee ontlasten we de assistenten. Dat geeft rust aan de voorkant van de praktijk. Dat is ook plezierig voor de patiënten, we bieden hen een extra service. ${ }^{321}$

\subsubsection{TEAM PAZIO@LRJG.VW}

Een paar dagen later hebben ons eerste PAZIO@LRJG.VW implementatieteamoverleg. Ik vertel kort de voorgeschiedenis en plannen met PAZIO, vervolgens vraag ik wanneer de PAZIO-implementatie voor elk van de teamleden geslaagd is. Straal vertelt dat PAZIO drempelverlagend kan werken voor patiënten. Het vraagt in het begin wat meer werk, maar kan op termijn verlichtend werken én het is leuk. Verder heeft het een opvoedende werking: patiënten kunnen dingen zelf doen en werken aan gezond leven. Het doel is om patiënten service te bieden en als gezondheidscentrum mee te gaan met de tijd en $24 / 7$ bereikbaar te zijn. Daarmee kan LRJG haar concurrentiepositie verbeteren en efficiënter werken, bijvoorbeeld door de telefoondruk op de praktijk te verlagen. ${ }^{322}$ 
Schuurman en Roemer zijn pragmatischer en praktischer als het gaat om tevredenheid. Schuurman is tevreden als de zorgverleners tevreden zijn. Roemer heeft eerder op andere locaties gewerkt met PAZIO en is positief kritisch op PAZIO. Voor Roemer is het geslaagd als het loopt: het werken met PAZIO moet voor patiënten en zorgverleners duidelijk en overzichtelijk zijn. Dan is het werkbaar. Straal voegt toe dat het een goede service aan patiënten moet worden. Schuurman vindt het van belang dat we klein beginnen en dus ook klein kunnen falen en snel kunnen leren. Ik vul aan dat we alleen zaken in de zorgpraktijk moeten introduceren die werken. Halfproducten leveren frustraties op bij zorgverleners en patiënten en dat zorgt voor demotivatie en afvallers.

In een volgende bijeenkomst merk ik op dat het van belang is om collega's geïnformeerd te houden over wat we doen en hun daarbij te enthousiasmeren. PAZIO moet gaan leven bij LRJG. Daarnaast is het van belang om over de communicatie richting de patiënten na te denken. De overgang van papier naar scherm is groot voor veel mensen. We kunnen mensen daarom het beste via e-mail benaderen, dan zitten ze al achter het scherm. Roemer merkt op dat de e-mailadressen tegenwoordig wel aan nieuwe patiënten gevraagd worden op het inschrijfformulier, maar dat het bestand allerminst volledig is en dat het de vraag is of je vanuit het HIS daarop kunt selecteren en een bulkmail kunt versturen. ${ }^{323}$

\subsubsection{DE DAGELIJKSE PRAKTIJK VAN DE HOOFDASSISTENTE}

Dinsdag 18 januari 2011 kijk ik een ochtend mee met Roemer om gevoel te krijgen voor de LRJG-praktijk en de werkprocessen. Roemer doet die ochtend de backoffice. Het is rustig vertelt ze me, dus er is ruimte om mee te kijken en dingen toe te lichten. Het huisartsinformatiesysteem Medicom wordt veel gebruikt voor recepten en herhaalrecepten, maar ook voor uitslagen. Alle berichten en uitslagen van een patiënt komen in Medicom, vertelt Roemer. De digitale berichten kunnen er zo in, de papieren post scannen we. De brieven zijn eenvoudig te koppelen aan de patiënt. Dat doet de arts in principe zelf. Die moet ook weet hebben van de uitslag en correspondentie. Tijdens de vakantie van de arts doet de assistente het. Het is belangrijk dat alles goed in het dossier komt. De telefoon gaat. Roemer neemt op. Ze vraagt naar de geboortedatum, dat blijkt de makkelijkste zoekmethode naar de patiënt. Er is een herhaalrecept nodig, voor een periode van drie maanden. Roemer print het recept uit en doet het in het plastic bakje van de betreffende arts. 
De arts moet het eerst controleren, voordat het naar de apotheek gaat. Roemer kan ook een digitaal recept aanmaken. Dat gaat dan via een buffer naar de arts die kan het controleren. De arts kan in haar spreekkamer ook zelf digitale recepten uitschrijven en versturen, dan is er uiteraard geen controle meer nodig.

Roemer laat zien hoe er afspraken gemaakt worden in de Medicom agenda. Bij elke afspraak schrijft de assistente in één regel het resultaat van de triage op. Ik vraag hoe dat bij een eAfspraak zou moeten gaan. Roemer vertelt dat je als praktijk het liefst vooraf wil weten wat de klacht is en zo nodig contact op neemt met de patiënt. We zouden het daarover met elkaar moeten hebben. Ondertussen gaat de telefoon continu. Roemer spreekt een patiënt die een arts wil spreken en daarna iemand die twijfelt over een consult. Dan belt er iemand die een afspraak wil. Het is steeds even aanpassen, knippen en plakken in Medicom. Roemer legt uit: in de Medicom agenda staan diverse reserveplekjes voor spoedgevallen op de dag zelf. Er staan er hier drie achter elkaar, wijst ze me aan, dat werkt niet en is onhandig. Zo houd je geen spreiding over de dag. In de praktijk zijn de zorgverleners met elkaar afspraken aan het maken om dat anders te doen.

Roemer moet even iemand een prik gaan geven. Als Roemer weer terug is pakt ze de aantekening die ze op papier makkt naar aanleiding van een telefoongesprek weer op. Roemer merkt opnieuw op dat het nu rustig is. Normaal is er continu telefoon. Waarna de telefoon weer gaat. Ik merk op dat er toch ook nu al vaak wordt gebeld, er komt van alles tussen door en vraag wanneer Roemer werkt aan langere klussen die concentratie vragen? Roemer vertelt dat je daarvoor 'uit de groep kan': dat wil zeggen dat je je telefoon uit de groep zet, zodat deze naar het antwoordapparaat schakelt. Dat is klantvriendelijker dan dat er de hele tijd niet opgenomen wordt. Ze erkent echter dat het werk inderdaad erg wordt bepaald door de telefoon en de balie als je in de groep zit.. ${ }^{224}$

\subsection{DE ONTWIKKELING VAN JULIUS ONLINE}

In afstemming met De Wit en het PAZIO-team gaat het implementatie team aan het werk met de volgende zaken: de introductie van het portaal PAZIO, de introductie van eConsult en van eAfspraak. In deze paragraaf beschrijf ik hoe de technologie en werkprocessen op elkaar worden afgestemd. Ik kijk naar welke problemen er ontstaan en welke 
oplossingen er ontwikkeld worden en wat de impact daarvan is op de zorgpraktijk, de zorgverleners en de patiënten.

\subsubsection{DE KEUS TUSSEN TWEE SCENARIO'S: HIS - OF PORTAAL-INTEGRATIE}

In november 2010 werd duidelijk dat PharmaPartners de hoofdprijs vraagt voor de integratie van PAZIO met hun huisartsinformatiesysteem Medicom via hun eigen portaal Mijngezondheid.nl (MGn). Die koppeling zou $€ 300.000$ moeten kosten. ${ }^{325}$ Dat bedrag is voor PAZIO zoveel te hoog dat er geen zelfs geen aanleiding is om hierover verder na te denken of te onderhandelen. PAZIO en PharmaPartners blijven wel in gesprek, maar slechts om oplossingen voor de lange termijn te verkennen. Naast dat er gewerkt moet worden aan een structurele oplossing voor de lange termijn, moet er ook gewerkt worden aan meer tijdelijke oplossingen voor de korte termijn.

Nadat bij LRJG duidelijk is geworden dat de HIS-integratie van PAZIO er voorlopig niet komt, ontstaat er een nieuwe uitdaging. Hoe zorgen we dat we PAZIO toch zo goed mogelijk kunnen inrichten voor LRJG? Zijn er zogenaamde workarounds, oplossingen die om het probleem van de afwezige HIS-integratie heen werken? Namens LRJG en het PAZIO-team ga ik te rade bij Pharmeon. Pharmeon is de leverancier van het eConsult dat gebruikt wordt binnen het UMCU en onderdeel is van de standaarduitrusting van PAZIO. Daarnaast is Pharmeon de bouwer van websites voor apothekers en huisartsenpraktijken, onder andere van de site van het LRJG.

Als duidelijk wordt dat PAZIO naar oplossingen zoekt met andere partijen, neemt PharmaPartners een andere houding aan in de gesprekken tussen het PAZIO-management en de PharmaPartners-directie. A. Dekker meldt dat PharmaPartners en PAZIO bereid zijn om een stap te zetten en de huisartsen naar de zin te maken. ${ }^{326}$ De MijnGezondheid.net-modules voor een eConsult en afspraak van PharmaPartners komen op de voorkant van de LRJG-site naast de PAZIO-knop te staan. Patiënten kunnen dan via DigiD inloggen in het eConsult en eAfspraak en komen vervolgens in de MGn omgeving van PharmaPartners. Voor de niet-PharmaPartnersmodules (zoals Diabetes Zelfmanagement en KleurjeLeven) kunnen patiënten inloggen bij PAZIO. De reacties uit het PAZIO-team op dit voorstel zijn weinig enthousiast. Flikweert concludeert dat dit voor de 
huisarts een optimale integratie in het HIS geeft, maar dat dit voor de patiënt suboptimaal is, want die moet nu via drie kanalen inloggen in plaats van via één portaal. M. Dekker merkt op dat PAZIO hiermee feitelijk in de koelkast wordt gezet. Ikzelf ben ook niet enthousiast en kan de reacties van Flikweert en M. Dekker goed begrijpen. ${ }^{327}$

De volgende dag bespreek ik de voortgang bij LRJG met de leden het PAZIO-management, A. Dekker en De Lange. ${ }^{328}$ Ik bereid me goed voor op de bespreking van het nieuwe PharmaPartners-voorstel. Vanuit mijn rol als implementatiemanager vind ik het van belang het perspectief van de gebruikers in de zorgpraktijk deze naar voren te brengen. Dat is mijns inziens bij implementatie essentieel en staat boven de technische benaderingen of mogelijkheden. In het PharmaPartners voorstel is het grote probleem dat de patiënt een versnippering van portalen krijgt, terwijl die portalen juist voor integratie van onlinezorgdiensten moeten verzorgen.

De oplossingen die PharmaPartners hier biedt leiden tot HIS-integratie, maar ook tot een desintegratie van PAZIO. De single sign on ${ }^{329}$ infrastructuur die uniek is voor PAZIO en essentieel voor het gebruikersgemak van de patiënten wordt hiermee overboord gezet. Dat is weliswaar tijdelijk, maar met wisselingen van inlogmethoden wordt het beeld voor de patiënten en zorgverleners niet duidelijker. Zo ontstaat er geen vertrouwde gewoonte voor zorg via het internet en geen vertrouwde nieuwe digitale behandelrelatie tussen patiënt en zorgverlener. Dat wordt verder versterkt doordat de andere onderscheidende meerwaarde van PAZIO in deze constructie ook het onderspit delft. PAZIO is white label, dat wil zeggen dat ze de digitale huisstijl van de zorgpraktijk overneemt en zelf als merk of product niet zichtbaar is. Voor de patiënt zal de functionaliteit die wordt geleverd wordt door PAZIO een vanzelfsprekende eenheid vormen met de website van de zorgverlener. De patiënt logt in in het digitale zorgportaal via de website van de zorgverlener en zal daarbij niet merken dat ze in technische zin naar een andere omgeving wordt doorgeschakeld. PAZIO wil zich richting de patiënt daarom juist niet profileren en in de digitale behandelrelatie onzichtbaar zijn. De zorgverlener bepaalt derhalve zelf welke naam hij geeft aan zijn digitaal zorgportaal. In de context van LRJG krijgt het zorgportaal de naam Julius Online.

Om de betrokkenen bij PAZIO en LRJG snel een beeld te kunnen geven van de verschillen tussen de twee scenario's, maak ik twee schetsen. 
Een van de MGn/PAZIO-constructie en noem deze het HIS-integratiescenario (fig. 4.2) en daarnaast het Portaal-integratiescenario waarin alleen met PAZIO gewerkt wordt.

\section{HIS-integratiescenario}

In het HIS-integratiescenario worden MGn en PAZIO gecombineerd aangeboden op de website van LRJG. Voor beide moet apart worden ingelogd met DigiD.

\section{PharmaPartners/MGn schema}

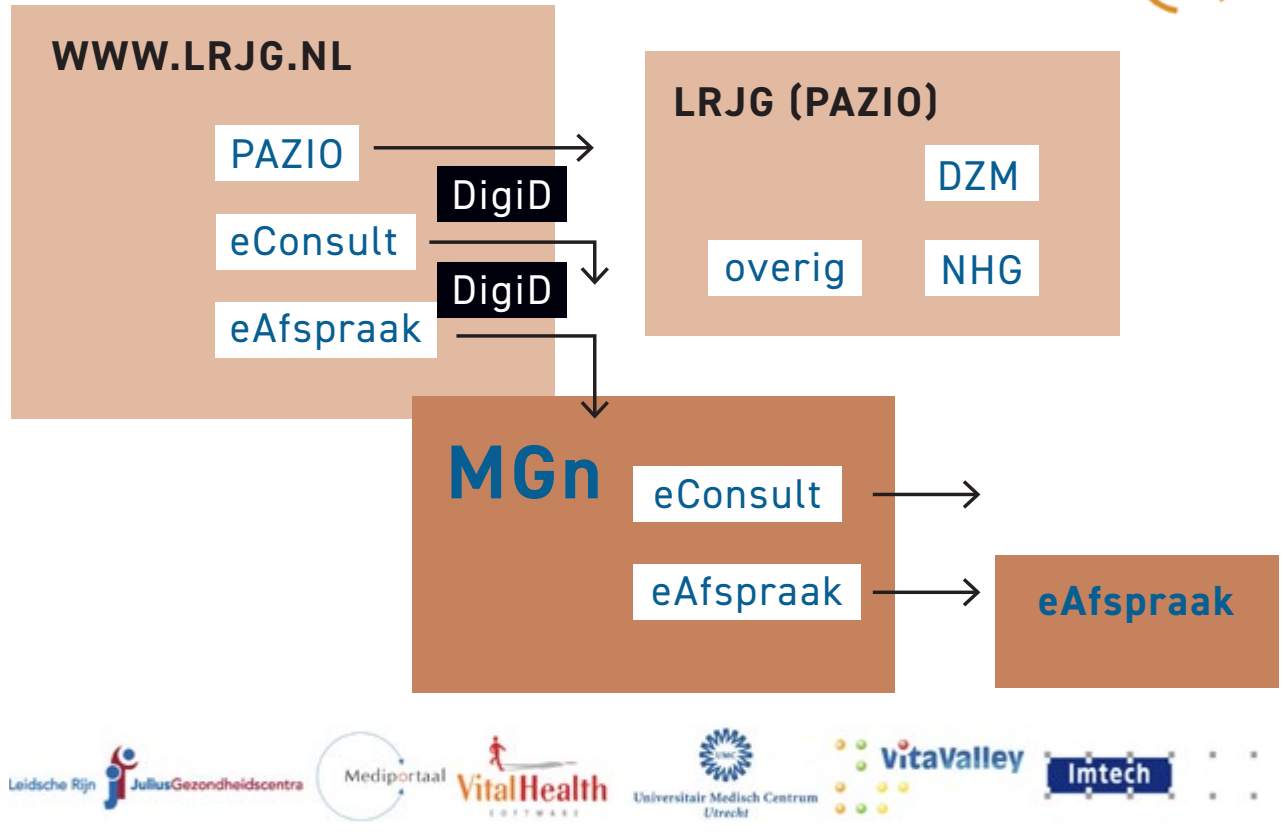

FIGUUR 4.2 HIS-integratiescenario.

MGn-portaal en Medicom-HIS zijn als producten van PharmaPartners optimaal geïntegreerd. Het HIS-integratiescenario met MijnGezondheid. net ( $M G n)$ maakt het werk voor de zorgverleners eenvoudig omdat het de zorgmodules (zoals eConsult en eAfspraak) daarin geïntegreerd zijn met het HIS. Voor de patiënt is deze HIS-integratie echter nauwelijks relevant, terwijl ze wel repercussies heeft voor de digitale behandelrelatie. 
MGn is een herkenbaar merk en product, dat zelf een relatie met de patiënt wil ontwikkelen. Ze neemt niet de huisstijl van het gezondheidscentrum over maar presenteert zich met haar eigen stijl. Het voorstel om PAZIO en MGn naast elkaar aan te bieden op de site van LRJG maakt de zaken voor de patiënten niet eenvoudiger: er worden twee digitale zorgportalen geopend. De patiënt vindt verschillende functionaliteiten in deze twee portalen, moet voor beide portalen apart inloggen en komt in een zichtbaar nieuwe digitale omgeving, zonder de vertrouwde huisstijl. De patiënt wordt geacht te schakelen tussen systemen, om te zorgen dat de zorgverlener in één geïntegreerd systeem kan werken. De eenheid die PAZIO nastreefde: één digitaal zorgportaal voor de patiënt, raakt hier versnipperd.

\section{Portaal-integratiescenario}

Tegenover het HIS-integratiescenario zet ik het Portaal-integratiescenario (fig. 4.3).

\section{Pharmeon/PAZIO schema}
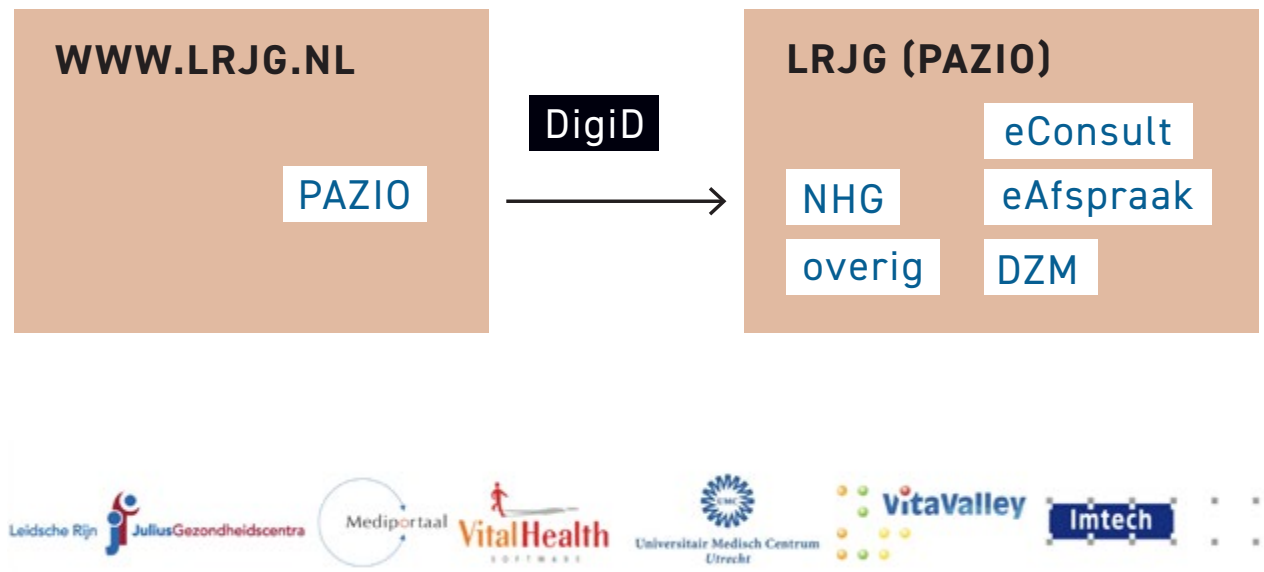

\section{vitaValley}


In het Portaal-integratiescenario is de situatie omgedraaid ten opzichte van het HIS-integratiescenario. Geen HIS-integratie betekent dat de zorgverleners werk moeten verrichten om hun digitale zorgactiviteiten in het HIS te krijgen. Voor de patiënt neemt het te verrichten werk echter af en ontstaat een overzichtelijke en eenduidige situatie. De patiënt vindt alle digitale zorg in één digitaal zorgportaal en dat zorgportaal is wat betreft look-and-feel geïntegreerd in de website van de zorgverlener. Het zorgportaal volgt de bestaande behandelrelatie tussen zorgverlener en patiënt, zorgt dat er een vanaf het begin één vaste plek ontstaat voor digitale zorg en dat die plek in de tijd stabiel is.

Ik stel het PAZIO-management voor om beide scenario's aan LRJG voor te leggen, zodat zij zelf voor hun praktijk de keuze kunnen maken waar ze de lusten en de lasten van hun zorgportaal leggen. Vooral

A. Dekker moet even slikken. Dat is begrijpelijk, er is enorm veel moeite gedaan om een volgende stap in samenwerkingsrelatie met PharmaPartners te zetten en daarmee te werken aan de HIS-integratie waar de zorgverleners zoveel belang aan hechtten. De gedachte dat dat nu niet verzilverd wordt valt hem zwaar, temeer daar de zorgvuldig opgebouwde en tegelijkertijd prille samenwerkingsrelatie met PharmaPartners nog kwetsbaar is. Desondanks is het PAZIO-management overtuigd van het belang om in ieder geval ook het portaal-integratie scenario aan LRJG voor te leggen. De besluitvorming wordt zo bij de klant gelaten. Belangrijke argumenten daarvoor is dat LRJG streeft naar efficiëntie en zorginnovatie. Ze hebben belang bij een stabiel zorgproces en goede service aan de patiënt; dat levert hun namelijk groei van de business op. Met name in Vleuterweide is dat van groot belang. Voor de gemiddelde patiënt geldt dat deze eenvoudig en intuïtief wil kunnen werken. Dingen moeten herkenbaar zijn. Patiënten willen niet uitproberen of experimenteren, maar eenvoudig werken. Routines moeten voor de patiënt vanzelfsprekend werken en niet merkbaar veranderd worden. Het HIS-integratiescenario van PharmaPartners gaat dat niet bieden en levert daarmee ook geen showcase voor PAZIO. ${ }^{330}$

Het alternatief dat ik voorleg aan het PAZIO-management is om een paralleltraject op te zetten rond het Portaal-integratiescenario. Dat scenario geeft de patiënt wel procesmatige helderheid en continuïteit, terwijl we werken aan optimalisatie van de HIS-integratie voor de zorgverleners. Het zou er zo uit kunnen zien: de eAfspraak-module waarvoor PAZIO nu nog afhankelijk is van PharmaPartners, wordt zo spoedig mogelijk met een derde partij, lees Pharmeon opgezet. Daarnaast optimaliseren we het eConsult in technische zin en minimaliseren we de werkdruk die 
de portaalintegratie voor de zorgverleners oplevert. Ook regelen we zo snel mogelijk de integratie van een eRecept module. Dat doen we samen met LRJG en VitalHealth Software. Ik bied aan om dat proces in gang te zetten.

Het alternatieve Portaal-integratiescenario betekent geen integratie met het HIS voor de huisartsen, maar wel procesmatige continuïteit, blijvende LRJG-look-and-feel en single sign on voor de patiënt. Vanuit herkenbaarheid kunnen we vertrouwen en betrokkenheid van patiënten opbouwen en vervolgens het portaal verder uitbouwen en optimaliseren, zeker ook voor de zorgverleners.

Op 1 februari spreek ik De Wit. Allereerst benoem ik het belang van een stabiel primair proces, voor LRJG en haar patiënten. Daarnaast leeft er bij LRJG de behoefte om een innovatieve academische eerstelijnspraktijk te zijn. Dat vraagt om een innovatieve houding waarbij er flexibiliteit is in het voorproces. Veranderingen zijn een intrinsiek gegeven bij innovatie, dus ook bij PAZIO. Maar we zorgen wel dat er bij implementatie steeds een stabiele situatie wordt neergezet. Verder kiezen we samen in het voortraject en delen we dan ook de consequenties. ${ }^{331}$

Daarna presenteer ik de scenario's voor HIS- en Portaal-integratie als mogelijkheden om invulling te geven aan de implementatie van PAZIO bij LRJG in de komende periode. Ik vertel daarbij dat ik met diverse zorgverleners en het PAZIO@LRJG.VW team heb gesproken over deze keuze tussen HIS- of Portaal-integratie. De meeste zorgverleners zagen de voordelen van HIS-integratie voor hun eigen werkprocessen. Tegelijkertijd hebben ze over hun schaduw heen kunnen springen en kiezen ze voor service aan de patiënt. Ik vraag hem of hij deze keuze kan ondersteunen. Dat doet De Wit onomwonden: 'Portaal-integratie is de weg om te gaan.'332

Die middag hebben we implementatie teamoverleg waarin ik aangeef dat ik de voor en nadelen van HIS- en Portaal-integratie met De Wit heb besproken en zijn voorkeur zonder meer naar Portaal-integratie uit gaat. Straal meldt dat de huisartsen het meest neigen naar HIS-integratie; dat is voor hun eigen werkprocessen optimaal. Tegelijkertijd waren het bieden van service en het ontwikkelen van een onderscheidende praktijk aanleidingen om in Vleuterweide met PAZIO te beginnen. Daarmee ligt Portaal-integratie voor de hand. Waarop ik aangeef dat we blijven werken aan de HIS-integratie en deze er later dit jaar ook nog komt. Tot die tijd kijken we of de eConsults als EDIFACT ${ }^{33}$ berichten naar het HIS kunnen 
sturen en we zo een workaround voor de HIS-integratie kunnen ontwikkelen. Die vraag is uitgezet bij Pharmeon. De keuze voor Portaal-integratie was een grote en belangrijke stap voor LRJG. Om tot een in de praktijk werkend portaal te komen is echter meer nodig dan besluiten over grote gedeelde problemen. De op het eerste gezicht meer praktische problemen vragen ook om zorgvuldigheid en aandacht. De grote ambities zijn in deze implementatie fase niet het grootste probleem. De Wit sprak in nog abstracte termen over een digitale schil om de praktijk. Straal maakt haar verwachtingen en ambities al concreter en praktischer door te spreken over de drempelverlagende werking van PAZIO: door PAZIO is de praktijk altijd bereikbaar voor de patiënt en hoef je de praktijk niet langer fysiek of telefonisch te bezoeken. ${ }^{334}$ Je kan vanuit elke locatie op elk tijdstip contact zoeken. Dat contact is dan weliswaar asynchroon: je kan altijd je vraag stellen of afspraak maken, maar je krijgt niet altijd ook direct een inhoudelijk antwoord. Het team PAZIO@LRJG.VW deelt die ambities. Zij willen de service richting de patiënt verbeteren, de praktijk toegankelijker maken en met hun tijd meegaan door een digitale ontsluiting te realiseren via PAZIO. ${ }^{335}$ Om dat te realiseren blijkt al snel meer nodig te zijn dan het neerzetten van de techniek van PAZIO in het gezondheidscentrum. Er moeten nieuwe relaties ontwikkeld worden tussen de praktijk en patiënt. Dat is niet eenvoudig en niet vanzelfsprekend, zeker niet als er gestreefd wordt naar onafhankelijkheid van tijd en plaats. Dat vraagt om nieuwe vormen van herkenning van de patiënt, nieuwe organisatie van de communicatie en de zorg voor heldere verwachtingen over en weer.

Gebruikers, in dit geval met name de patiënten van LRJG, zijn eraan gewend en verwachten dat digitale services en dus ook de digitale behandelrelatie op een vanzelfsprekende intuïtieve manier werken. PAZIO probeert daaraan tegemoet te komen door aan te sluiten bij het internetjargon van deze tijd. Waar in de ontwikkelfase gesproken werd van het eConsult wordt dat bij de pilot implementatie bij LRJG vervangen door Consult Online en zo worden eAfspraak en eRecept vertaalt naar Afspraak Online en Recept Online. ${ }^{336}$ In de LRJG-praktijk verdwijnt ook de productnaam PAZIO. PAZIO wil immers white label opereren en optimaal aansluiten bij de bestaande behandelrelaties van LRJG. PAZIO wordt daarom herdoopt tot Julius Online. In aansluiting daarop wordt met iconen een beeldtaal ontwikkeld die aansluit bij de digitale gewoonten 
en cultuur op het internet. De iconen verbeelden de digitale zorg en vervangen daarmee tekstuele routing of aankondigingen. De patiënt wordt via iconen door de diverse stadia naar digitale zorg begeleid. De iconen zijn een aanduiding van wat er gaat komen aan digitale zorg. Door op een icoon te klikken wordt de digitale zorg betreden. Op de website van LRJG wordt een icoon voor het vinden, aanmelden en inloggen bij Julius Online (fig. 4.4) geplaatst.

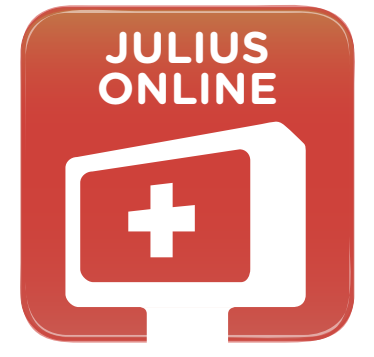

FIGUUR 4.4 Icoon Julius Online.

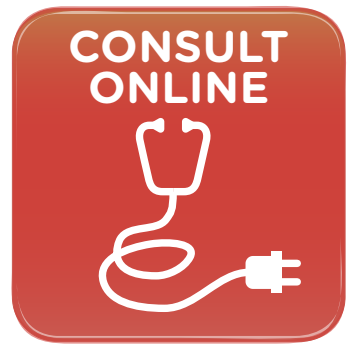

FIGUUR 4.5 Icoon Consult Online. ${ }^{337}$

Binnen Julius Online navigeren de iconen de patiënt door het aanbod van digitale zorg tools zoals Consult Online en Afspraak Online (fig. 4.5). Met de iconen worden de nieuwe relaties die nodig zijn voor digitale zorg, tussen zorgverlener en patiënt, en tussen tijd, plaats en tekst op een nieuwe manier ondersteund.

\subsubsection{AUTHENTICATIE}

Een behandelrelatie tussen patiënt en zorgverlener is een persoonlijke relatie, die vertrouwen en veiligheid moet bieden. Beroepsgeheim en privacygaranties zijn daarvoor belangrijke voorwaarden: de zorgverlener wil zekerheid hebben over de identiteit van zijn patiënt. Die zijn voor de zorgverlener niet alleen van belang in het primaire zorgproces, maar ook voor de dossiervoering, administratie en declaratie bij de verzekeraars. In de spreekkamer is de check meestal eenvoudig met één blik op de patiënt verkregen, digitaal is die vanzelfsprekende herkenning 
niet mogelijk en moeten er andere procedures ontwikkeld worden. Dat is zo belangrijk dat er een nieuw woord voor is geïntroduceerd in het jargon: authenticatie.

In de zorg en voor PAZIO heeft men toestemming gekregen om DigiD te gebruiken. DigiD staat voor Digitale Identiteit en is gekoppeld aan het Burgerservicenummer. Ze legt een unieke relatie tussen de persoon en zijn of haar digitale identiteit. DigiD is oorspronkelijk ontwikkeld voor de digitale relatie tussen burger en overheden, maar wordt ondertussen ook ingezet in de zorg om de digitale behandelrelatie tussen patiënt en zorgverlener om de patiënt te authentiseren. ${ }^{338}$ In de praktijk is DigiD echter zowel een oplossing als probleem. Tijdens een testsessie van PAZIO met patiënten in Vleuterweide ${ }^{339}$ bleek dat slechts twee van de vijf test-patiënten beschikten over DigiD met sms-authenticatie. Voor andere patiënten was DigiD onbekend terrein en daarmee een extra hobbel voor het ontwikkelen van een digitale zorgrelatie. Een DigiD moet worden aangevraagd en er moeten adresgegevens en Burgerservicenummer worden overlegd. Na enkele werkdagen ontvangt de aanvrager dan een activeringscode per post waarmee de aanvrager online zijn DigiD kan activeren en kan gaan gebruiken. Vanuit het streven naar authenticatie van een werkelijke persoon in een digitale omgeving is een dergelijke aanvraagprocedure begrijpelijk, nuttig en noodzakelijk. Tegelijkertijd sluit ze niet aan op de verwachtingen van mensen over gemak en toegankelijkheid van digitale diensten: we zijn gewend aan directe toegang, zonder werkdagen als wachttijd en zonder ervaren traagheid van de papieren post. Daarmee vormt DigiD een drempel bij het gebruik van PAZIO. De patiënt heeft sneller een afspraak, consult, recept geregeld door op de bestaande traditionele manier de praktijk te bellen of bezoeken, dan, in ieder geval de eerste keer, via DigiD en PAZIO. Dat wordt erkend door alle betrokken vanuit LRJG ${ }^{340}$ en PAZIO. Helaas kan men niet om DigiD heen: er is geen alternatief dat alleen al aan de juridische eisen voldoet.

\subsubsection{ECONSULT}

Een zorgverlener mag wettelijk gezien niet e-mailen met zijn patiënten. Medische informatie mag niet uitgewisseld worden over het alledaagse internet; dan voldoet men niet aan de juridische normen voor beveiliging van persoonsgebonden medische informatie. ${ }^{341} \mathrm{Om}$ een 
functionaliteit te bieden die vergelijkbaar is met e-mail, maar voldoet aan de wettelijke eisen, is het eConsult ontwikkeld. De consequentie daarvan is dat de patiënt moet inloggen met DigiD. Zo op het eerste gezicht biedt het eConsult een mooie functionaliteit, die een digitale ontsluiting en invulling voor de behandelrelatie aanreikt, een extra service biedt aan de patiënt en hem of haar mogelijk meer regie geeft in zijn zorgproces. In de praktijk blijkt het echter een flinke klus om een werkbare digitale behandelrelatie te ontwikkelen.

De eConsult module die onderdeel is van de standaarduitrusting van PAZIO, komt van Pharmeon. Kreitz, de directeur van Pharmeon, vertelt me op 15 november 2011 dat er binnen een gezondheidscentrum twee opties zijn voor het inregelen van het eConsult. De eConsult-vraag van de patiënt gaat óf direct naar de betreffende zorgverlener óf er wordt een eConsult-pool gemaakt, die beheerd wordt door een werkvoorbereider. Deze heeft centrale toegang: hij verdeelt de eConsults, beantwoordt of bereidt de antwoorden in concept voor en houdt zicht op de eConsults die nog onbeantwoord zijn. Als de werkvoorbereider er niet is, kan hij de eConsult-pool doorzetten naar een ander. ${ }^{342}$

Binnen het LRJG werkt het merendeel van de zorgverleners in deeltijd of combineert de professionele zorg met onderzoek en onderwijs. Zorgverleners zijn daardoor niet dagelijks beschikbaar. Het begrip 'eigen huisarts' is daarmee aan inflatie onderhevig. Zo zijn er huisartsen in Vleuterweide die maar één dag per week werkzaam zijn. Dat gaat moeilijk samen met de eventuele ambitie om een persoonlijke band met de patiënten op te bouwen, de kans dat hij of zij beschikbaar is voor 'eigen patiënten' is relatief klein. Het gezondheidscentrum zorgt dat er altijd een geschikte zorgverlener voor de patiënt is. Zorgverleners zijn voor het gezondheidscentrum, net zoals de spreekkamers en apparatuur, tot op zekere hoogte inwisselbaar. Het gezondheidscentrum is de eenheid van dienstverlening en voert de regie, niet de patiënt noch de zorgverlener. Dat geldt in de reguliere behandelrelatie in de spreekkamer, maar niet minder in de digitale behandelrelatie. Want hoewel een eConsult in de praktijk niet bedoeld is voor urgente zaken, vraagt een aantrekkelijke en zinnige eConsult-service wel om een reactietijd van maximaal 24 uur. De eerste optie, waarbij een eConsult van de patiënt direct naar een specifieke zorgverlener gaat, vervalt daarmee. Als ik in augustus 2010 in mijn inventarisatieronde huisarts Van der Brekel van de locatie Terwijde spreek, meldt zij direct dat er afspraken gemaakt moeten worden over de eConsult-logistiek. Wat haar betreft komen die binnen 
bij de hoofdassistente, die stuurt ze door naar de desbetreffende arts. Als de arts reageert, moet de hoofdassistente daarvan een bericht krijgen. Reageert de arts niet, dan moet de hoofdassistent een herinnering sturen. ${ }^{343}$

Door de inlog van patiënten via DigiD weet een zorgverlener altijd wie van zijn of haar patiënten hem of haar een eConsult stuurt. De zorgverlener weet wie hij of zij in de digitale behandelrelatie tegenover zich heeft. Het is voor de patiënt echter niet transparant welke zorgverlener op zijn of haar eConsult reageert, laat staan dat de patiënt daar de regie over heeft. De ambitie om de patiënt centraal te zetten betekent in de LRJG-context niet dat de patiënt overzicht en regie gegeven wordt. Organisatorisch en logistiek staat het gezondheidscentrum centraal. De patiënt staat centraal omdat deze een nieuwe digitale toegang tot de behandelrelatie krijgt van het gezondheidscentrum. De patiënt centraal stellen betekent in het geval van het eConsult een nieuwe service bieden en niet zozeer een bijdrage leveren aan transparantie voor en regie door de patiënt.

Hoofdassistente Roemer heeft al bij de eerste implementatiepoging aangegeven dat het onhandig is dat de eConsults van de patiënten van alle vier de LRJG-locaties in een verzamelbak terecht komen. ${ }^{344}$ Pharmeon heeft daarom in de eConsult-module de locatiekeuze opgenomen. Het PAZIO@LRJG.VW-team ziet die optie tijdens een demonstratie op 6 januari 2011. Door de keuze voor locatie krijgt de patiënt niet langer alle LRJG-zorgverleners meer te zien, maar alleen diegene die op de aangeklikte locatie werken. De patiënt kan voor een zorgverlener kiezen. Daarmee wordt op zijn minst de suggestie gewekt dat de betreffende zorgverlener het eConsult ook zal ontvangen, maar dat blijkt echter niet vanzelfsprekend het geval. De woordkeuze wordt serieus besproken: moet men kiezen voor een discipline, behandelaar of zorgverlener? In het zoeken naar de juiste inrichting en vormgeving van de digitale behandelrelatie, is het zoeken naar de juiste termen en begrippen een serieuze zaak. De terminologie is hier des te meer van belang, omdat het hier om een innovatieve situatie gaat, die mede vorm krijgt door de gekozen terminologie. Op basis van die terminologie moet worden gehandeld door de patiënt. De situatie is zo nieuw dat het team niet zeker is of de patiënt in staat is elke keuze verstandig kan maken. Daarom wordt zowel bij locatie als bij zorgverlener de optie om 'onbekend' te kiezen mee genomen. In de dagelijkse fysieke praktijk is het moeilijk voorstelbaar dat een patiënt de locatie of zorgverlener waar 
hij een afspraak mee heeft niet zou weten, in de digitale behandelrelatie durft het team daar nog niet op te rekenen. De optie 'onbekend' roept echter meteen een vervolgvraag op: bij wie komen de als 'onbekend' gemarkeerde eConsults terecht? Bij de hoofdassistent, die kan vervolgens immers uitzoeken bij welke locatie een patiënt is ingeschreven en wat zijn of haar 'eigen' huisarts is, zo is de gedachte bij de LRJG-ers.

De volgende vraag voor het implementatieteam is waar de wél aan een specifieke locatie en zorgverlener gerichte eConsults terecht komen. In eerste instantie is iedereen het erover eens dat die bij de desbetreffende zorgverlener terecht moet komen. Als men probeert zich dat voor te stellen, wordt al snel duidelijk dat minder vanzelfsprekend is dan gedacht. Wat nu als een $\mathrm{POH}^{345}$ maar drie dagen in de week werkt, een arts ziek is of onderzoek doet en twee dagen niet aanwezig is? Het is van belang dat er iemand overzicht houdt over de eConsults die binnen komen. Alle eConsults zouden om die reden moeten binnen komen bij de hoofdassistente.

Als alle berichten bij de hoofdassistente terecht komen is de vraag waarom de patiënt nog voor een zorgverlener zou moeten kiezen. Is dat nuttig en geeft dat de patiënt een juiste indruk over wat er met zijn eConsult gebeurt en door wie het gelezen wordt? Er ontstaat een spanning tussen het ideaalbeeld van de behandelrelatie dat de zorgverleners in stand willen houden en de weerbarstige praktijk. De ervaring leert dat patiënten helderheid over wie ze online voor zich hebben van belang vinden. Mevrouw Zijlstra zal later tijdens een testsessie van Julius Online vragen wie het eConsult als eerste leest en of ze ook een eConsult kan sturen als haar arts vrij heeft? ${ }^{346}$ Het is dus van belang om die vraag helder te beantwoorden en om het vertrouwen in de behandelrelatie niet te schaden. Juridisch is een dergelijke persoonlijke behandelrelatie tussen zorgverlener en patiënt niet van belang. Zoals alle bij een patiënt betrokken zorgverleners het dossier in het HIS mogen inzien, zo mogen zij ook een eConsult van een bij de praktijk ingeschreven patiënt beantwoorden. Tegelijkertijd zien de zorgverleners in het team de keuzes van zorgverleners door de patiënt bij een eConsult juist ook als onderdeel van het opbouwen van, dan wel de suggestie van, een persoonlijke band in het kader van de behandelrelatie. Klaarblijkelijk wil men zelf ook iets in stand houden en blijven geloven in iets dat er in de praktijk steeds minder is: een persoonlijke band of unieke behandelrelatie tussen zorgverlener en patiënt. ${ }^{347}$ Uiteindelijk wordt 
besloten om alle eConsult bij de hoofdassistente binnen te laten komen en van daaruit te verspreiden naar de diverse zorgverleners. Daarnaast blijven de keuzes van de patiënt voor locatie en zorgverlener bestaan, ondanks dat die keuzes er in de praktijk praktisch niet of nauwelijks toe doen. De vraag rest of en hoe de patiënt moet worden uitgelegd dat het eConsult ook door de assistente beantwoord of in ieder geval gelezen kan worden. Gesuggereerd wordt om de antwoorden van de eConsult te laten beginnen met 'in nauw overleg met uw arts kan ik u meedelen ... ؛ Uiteindelijk wordt besloten dat hierover een uitleg moet worden opgenomen in de gebruiksaanwijzing voor het eConsult. Daarin moet naar de patiënt gecommuniceerd worden dat er een andere zorgverlener kan antwoorden dan de patiënt zelf geselecteerd heeft. Een door de zorgverleners ervaren relationeel probleem wordt zo tekstueel opgelost. ${ }^{348}$

Een volgende kwestie voor de zorgverleners is de inhoud en omvang van een eConsult. Huisarts Straal vertelt dat ze in een praktijk waar zij werkte al ervaring heeft opgedaan met eConsult. Ze heeft daar geleerd dat je als zorgverlener zomaar de regie kwijt kunt raken met de inzet van een eConsult. Ze kreeg wel eens eConsulten met een omvang van meer dan twee A4 geschreven tekst. Patiënten schrijven hele epistels over hun geschiedenis en situatie, over hun pijn en problemen. Dat is niet werkbaar, vindt ze. Ze stelt daarom voor het tekstveld in de eConsult-module te beperken tot een omvang van een half $\mathrm{A} 4$. Vanuit zorgverlenersperspectief is dat een begrijpelijk voorstel.

Voor een doktersbezoek in de praktijk staat tien minuten waarin de patiënt één klacht aan de orde mag stellen. Dat is de formele consultafbakening op basis waarvan gepland en gewerkt wordt. Die tijd wordt door de verzekeraar vergoed. Het tarief voor een consult is in die tijd $€ 9,11 .{ }^{349}$ Overigens kan een patiënt wel een dubbel consult aanvragen of een (vervolg)afspraak maken waardoor meer ruimte ontstaat binnen de financiële kaders. Dergelijke financiële grenzen gelden ook voor de digitale behandelrelatie. Het tarief voor een e-mailconsult is de helft van een regulier consult, namelijk $€ 4,56 .{ }^{350}$ Omgerekend naar tijd heeft de zorgverlener dan in principe vijf minuten voor de beantwoording van het eConsult. Straal geeft aan dat dat niet in verhouding staat tot de tijd die er in de praktijk voor nodig is om een eConsult goed te beantwoorden en verwerken. ${ }^{351} \mathrm{Om}$ het eConsult werkbaar te houden moet ook de patiënt maathouden en geen eindeloze epistels schrijven. Patiënten stellen in één 
eConsult ook regelmatig meerdere vragen en ook dat past niet in de vergoeding meldt Straal. Je mag zo'n eConsult immers niet dubbel declareren. Ze stelt ook hiervoor een tekstuele oplossing voor: in de voorwaarden moet worden opgenomen dat zoiets niet kan. Schuurman, de ICT-beheerder bij LRJG merkt op dat je de patiënt toch niet kunt verbieden meerdere vragen te stellen. Vanuit patiëntenperspectief is dat juist effectief en efficiënt. Een patiënt maakt niet bij voorbaat onderscheid tussen klachten en weet niet altijd welke verbanden er zijn en welke zaken relevant zijn.

Resumerend kunnen we concluderen dat het eConsult wordt gepresenteerd als middel om de patiënt de regie te geven en centraal te stellen. In de praktijk is dat echter geen sinecure. Het eConsult blijkt geen deus ex machina, die problemen als sneeuw voor de zon doet verdwijnen. Om het eConsult te laten werken moet een nieuwe digitale behandelrelatie worden opgebouwd. Dat vraagt om aanpassingen aan zorgverlenerszijde en organisatorische inbedding in het gezondheidscentrum, maar tegelijkertijd wordt er ook veel van de patiënt verwacht. Patiënten moeten de gebruiksaanwijzing, welkomteksten en voorwaarden lezen en zich eraan houden. Ze moeten in staat zijn om een kort en krachtig niet meer dan één zorginhoudelijk vraag per eConsult te schrijven voor de zorgverlener. Ze moeten de digitale vaardigheden hebben om via websites, DigiD, iconen en keuzemenu's de juiste digitale behandelrelatie te initiëren. De zorgverlener wil vanuit efficiëntie-oogpunt de regie houden en daarbij wordt veel van de verantwoordelijkheid en de inzet van de zorgverlener naar de patiënt verplaatst. Waar eerder uitdrukkelijk gekozen werd voor portaal-integratie om de patiënt centraal te zetten, blijkt in de uitwerking de zorgverlener vrijwel onbewust toch weer de regierol op zich te nemen.

\subsubsection{EAFSPRAAK}

Nadat in de loop november 2010 het gebruik van MijnGezondheid.net bij LRJG van de baan is, verdwijnt ook de mogelijkheid voor LRJG om gebruik te maken van de afsprakenmodule die in MGn was opgenomen. PAZIO moet snel op zoek naar een alternatief, want bij LRJG zijn ze juist op mijn aandringen enthousiast geworden voor het online laten inplannen van afspraken door patiënten zelf. Ik neem daarover contact op met Pharmeon. Zij zijn ook de leverancier van het eConsult in PAZIO en hebben eerder aangegeven zo'n eAfspraak module in de aanbieding te hebben. ${ }^{352}$ Helaas blijkt in de aanbieding hebben iets minder concreet dan ik eerder begrepen had. Pharmeon heeft inderdaad een prima eAfspraak-module, die ook goed integreert met een HIS, als 
een HIS daarvoor open staat. Dat laatste is met Medicom, het HIS van PharmaPartners dat bij LRJG gebruikt wordt, nu juist niet het geval. Het alternatief is een stand alone eAfspraak-module. Die is Pharmeon aan het ontwikkelen, maar is pas eind 2011 gereed. ${ }^{353}$ Dat is te laat voor PAZIO en LRJG. Gelukkig is men bereid de ontwikkeling van de stand alone eAfspraak module naar voren te halen en wordt beloofd deze in maart 2011 gereed hebben. ${ }^{354}$ Dat maakt het werkbaar voor LRJG.

We praten verder over de functionaliteit en beperkingen van een stand alone eAfspraak-module. De belangrijkste beperking is dat de module en het HIS niet geïntegreerd zijn. Daardoor kunnen afspreken niet eenvoudig definitief gemaakt en naar de patiënt bevestigd worden. De HIS-agenda is immers leidend. Het afspraakvoorstel van de patiënt uit de eAgenda-module moet handmatig overgezet en gecontroleerd worden in de HIS-agenda. Pas daarna kan een definitieve bevestiging naar de patiënt gestuurd worden. Het is daarom goed om naar LRJG duidelijk te maken dat de stand alone voorziening een tussenoplossing is om LRJG uit de brand te helpen en de HIS-leveranciers onder druk te zetten om te integreren.

De Lange, die vanuit PAZIO verantwoordelijk is voor productontwikkeling, vertelt dat het van belang is dat er in de module een rolling forecast mechanisme zit. Hiermee wordt het bijvoorbeeld mogelijk om standaard in het systeem op te nemen dat je niet voor de volgende dag afspraken kunt maken. Ook moet er dan een afsprakenoverzicht gegenereerd kunnen worden. Dat maakt de overname van de afspraken in de HIS-agenda eenvoudiger. Kreitz herkent het belang daarvan. Zijn ervaring met huisartsen is dat ze vaak alleen voor bepaalde zaken afspraken online willen plannen, bijvoorbeeld voor wratten, griepvaccinatie en controles van chronisch zieken. We spreken af dat de module begin maart gereed is en we dan feedback vragen vanuit Vleuterweide.

Straal is direct enthousiast over het implementeren van een eAfspraak module. De eAfspraak module vindt ze belangrijker dan het eConsult. Voordeel van eAfspraak is volgens Straal ook dat

'mensen's nacht ook afspraken kunnen maken. Als je 's nachts bijvoorbeeld pijn hebt of rectaal bloedverlies, waar mensen altijd erg van schrikken, kan het een opluchting zijn als je voor de volgende dag een afspraak hebt staan. Daarnaast kan 
een eAfspraak module de enorme telefoondruk op de praktijk verminderen. De eAfspraak geeft rust aan de voorkant van de praktijk. Die is nu telefonisch de hele dag open. Dat is plezierig voor de patiënt, maar daardoor is het voor de assistenten lastig te plannen wanneer ze rustig kunnen werken aan meer tijdsintensieve zaken.' ${ }^{355}$

Roemer geeft aan dat er een grote druk op de agenda van de praktijk in Vleuterweide zit. Ze zitten nu bijvoorbeeld al vol tot overmorgen. Er zijn te veel patiënten en te weinig consultplekken. Dat lijkt mij een goede reden om met eAfspraak te beginnen, maar Roemer geeft aan dat het net zo goed kan betekenen dat mensen toch gaan bellen als de eAfspraak agenda volgeboekt is. Straal zoekt de oplossing in heel andere richting, ze is nog steeds voor een inloopspreekuur aan het begin van de dag. Daarmee neem je de onrust weg voor de patiënten, ze kunnen altijd binnen lopen. Roemer is daar minder gelukkig mee: dan staan buiten al patiënten te wachten, als zij's ochtends als eerste de praktijk ingaat. Dan begint de praktijk de dag onrustig en ongepland.

Op 8 februari 2011 kijken we tijdens het wekelijks werkoverleg van de projectgroep PAZIO@LRJG.VW naar de dan beschikbare eAfspraak-module van Pharmeon. ${ }^{356}$ Zichtbaar wordt dat in de eAfspraak-module terugkerend blokken kunnen worden gereserveerd die open worden gesteld voor het maken van eAfspraken door patiënten. Vakanties, nascholingen en andere terugkerende zaken kunnen worden ingepland. En zo kan ook worden geregeld dat er alleen voor overmorgen en daarna afspraken gemaakt kunnen worden. De LRJG-ers zijn tevreden over wat ze bij Pharmeon te horen en te zien krijgen over de eAfspraak-module. Ze ervaren het als een gebruikersvriendelijk en goed werkend systeem. Dat neemt niet weg dat er ook vragen en uitdagingen zijn. Roemer merkt op dat de kleuren en stijl anders zijn dan bij PAZIO. Tot haar teleurstelling moet ik haar vertellen dat dat zo zal blijven, want leveranciers van modules nemen hun eigen stijl mee. PAZIO neemt de look-and-feel over van LRJG, maar de modules zullen dat niet zonder meer ook doen.

In de agenda voor de eAfspraak staat standaard tien minuten per te maken afspraak gepland. Straal merkt echter op dat het in de praktijk sommige dingen om meer dan tien minuten vragen, bijvoorbeeld psychische klachten, arbeidsconflicten. Roemer geeft aan dat je dergelijke gevallen bij telefonische afspraken er al grotendeels uit filtert door middel 
van triage. Je kan de afspraak dan verlengen en de arts alvast informeren. Mocht er toch tijd tekort zijn dan vraagt de huisarts aan de patiënt tegenover haar wat hij of zij op dit moment nodig heeft en maakt een nieuwe afspraak voor de bredere kwestie. Omgekeerd worden alledaagse zaken als oren uitspuiten, bloeddruk meten, injecties in de praktijk door de assistente gedaan en niet door de huisarts.

Geconcludeerd wordt dat er duidelijke spelregels moeten worden opgezet voor het plannen van afspraken via de eAfspraak-module. Daarbij is het niet de gedachte dat patiënten er zich er dan altijd aan houden, maar dat er in voorkomende gevallen wel naar verwezen kan worden. De voorwaarden moeten dan ook helder naar de patiënten gecommuniceerd worden. Afgesproken wordt dat bij eAfspraak moet worden aangegeven dat er maar één klacht per keer behandeld kan worden. Voor meerdere klachten moet de patiënt ook meerdere consult afspraken plannen. Voor spoedeisende klachten kunnen geen afspraken gemaakt worden via eAfspraak. Daarom wordt het in eAfspraak ook niet mogelijk om voor de volgende (werk)dag een afspraak te plannen. Het is alleen mogelijk om voor overmorgen en daarna een afspraak te maken via eAfspraak. We moeten een lijstje met verrichtingen maken die door de assistent kunnen worden uitgevoerd en daarbij naar de assistentenagenda verwijzen. Getwijfeld wordt of er voor psychische zaken of meerdere klachten consults van twintig minuten aangeboden moeten worden. Gekozen wordt om het niet te complex maken en te starten met alleen enkelvoudig afspraken voor een consult van tien minuten. ${ }^{357}$

Omdat eAfspraak een stand alone applicatie is die niet geïntegreerd is met de HIS-agenda, worden afspraakverzoeken van de patiënt niet direct verwerkt in de in de praktijk leidende HIS-agenda. Roemer stelt daarom de terechte vraag of patiënten na het plannen van een afspraak via eAfspraak meteen een bevestiging krijgen dat deze akkoord is. De verwachting is dat de patiënt daar wel op rekent en als de bevestiging niet eenduidig gegeven wordt, gaan patiënten alsnog bellen of negeren het eAfspraak systeem. We concluderen dat een automatische afspraakbevestiging nodig is. Dat vraagt echter wel om een zorgvuldige afstemming tussen de eAfspraak agenda en de HIS-agenda. Omdat automatische synchronisatie niet mogelijk is, is een zorgvuldige handmatige synchronisatie essentieel.

Om dubbele afspraken als gevolg van de dubbele agenda's te voorkomen, wordt ervoor gekozen om tijdsblokken in de HIS-agenda te blokken en die open te stellen in de eAfspraak-agenda. Vervolgens is de vraag hoe die agenda's gesynchroniseerd worden. Ik vertel dat het mogelijk is dat de 
(hoofd)assistente via e-mail direct een notificatie krijgt als een patiënt via de eAfspraak module een nieuwe afspraak heeft gemaakt. Voor Roemer is dat geen optimale oplossing, dan moet ze haar e-mailaccount continu monitoren en berichten snel verwerken. De kans is te groot dat dat misgaat, als iemand even met andere werkzaamheden bezig is of afwezig is. Als ik aangeef dat het ook mogelijk is om de eAfspraken te exporteren naar een Excel lijst, zodat je vanaf die lijst de afspraken kan verwerken in de HIS-agenda, wordt duidelijk dat het aanleveren en verwerken van de eAfspraken in de praktijk niet het grootste probleem is voor de (hoofd) assistenten. Cruciaal is de timing van de verwerking van de afspraken.

Voor het afsprakenmanagement van de LRJG-praktijk is het van belang dat de agenda's up-to-date zijn. Roemer, die de huidige praktijk het beste kent, merkt op dat het belangrijk is dat de eAfspraak 's ochtends als eerste overgenomen worden in het HIS. Dan kun je de plekken die nog over zijn nog invullen met de telefonische afspraakverzoeken en vallen er geen onnodige gaten in de spreekuren. Daarnaast is dan een helder overzicht over wat er die dag en de dag erna gaat komen.

Idealiter worden de afspraken via de eAfspraak-module dan 's ochtends om half acht meteen door de assistente verwerkt in de HISagenda. In de praktijk is daar echter op dat moment geen tijd voor. Je bent als assistente dan druk bezig met andere zaken. Om overzicht te hebben over wat er nog open staat moeten de eAfspraken de dag ervoor al worden ingevoerd. Als je dat bij sluiten van de praktijk om 17 uur doet mis je de afspraken die patiënten maken tussen 17 uur en 24 uur. Dan heb je dan ook geen zekerheid over je nog telefonisch te vergeven consulttijden voor de volgende dag. Roemer concludeert dat er nog heel wat logistiek moet worden uitgedacht rond het gebruik van de eAfspraakmodule in de LRJG-praktijk. Daarbij gaat het haar niet eens zo zeer om het extra werk. Ze verwacht dat het overzetten van de afspraken niet bijzonder veel tijd zal vragen, het gaat haar veel meer om het vinden van een geschikt moment om dat werk te doen. Daarnaast moeten we de voorwaarden helder naar de patiënten gecommuniceerd worden. Een eAfspraak is ongeschikt voor spoedeisende zaken en kan alleen voor 'overmorgen' gemaakt worden. We moeten een lijstje met verrichtingen maken die naar de assistentenagenda verwijzen. ${ }^{358}$

De eAfspraak module biedt een nieuwe manier om met tijd om te gaan. Tegelijkertijd betekent dit dat zowel patiënten als zorgpraktijk en zorgverleners zich opnieuw moeten verhouden tot het maken van 
afspraken en het omgaan met tijd. Patiënten moeten leren wanneer en waarvoor ze hoeveel tijd mogen vragen van hun zorgverleners, nu dat niet meer via triage door de zorgverleners zelf kan worden gemonitord. Omgekeerd moeten de zorgverleners zich opnieuw verhouden tot hun agenda. Zoals Roemer opmerkt: het moet onderdeel van het werken worden, je moet het in je hoofd en in je vingers hebben en kunnen delen met collega's. Er moeten nieuwe gewoonten en processen ontstaan.

Het is waardevol dat Pharmeon, de ontwikkelaar van eAfspraak, meewerkt aan het ontwikkelen van de nieuwe gewoonten. De eAfspraak-module en de LRJG-praktijk vormen zich gezamenlijk. Op dinsdag 12 april 2011 heeft Pharmeon voor het projectteam PAZIO@LRJG.VW een statussessie georganiseerd rond de ontwikkeling van de eAfspraak module. Daarin worden use cases (gebruikssituaties) van eAfspraak gepresenteerd en besproken. Er wordt ingegaan op het wijzigen van instellingen in de agenda door de beheerder, het aanmaken van tijdsblokken, het maken van een afspraak door een patiënt en het wijzigen van een afspraak door de beheerder vanuit LRJG. In die sessie worden schoonheidsfoutjes uit het systeem gehaald, maar wordt er ook nagedacht over automatisch gegenereerde berichten. De userinterface wordt geoptimaliseerd en het aantal benodigde klikken om een bepaalde functionaliteit te gebruiken geminimaliseerd. Zo vertelt Roemer dat geboortedata van patiënten voor haar een essentieel gegeven zijn in de praktijk. Daarmee worden patiënten opgezocht in het HIS, aan de hand van de geboortedata koppelen de assistenten de patiënten aan de zorgprocessen en praktijken. Voor Pharmeon wordt zo helder dat de geboortedatum ook zichtbaar moet zijn bij eAfspraken. De zorgverleners vragen om een extra veld, maar Pharmeon stelt een praktischer optie voor: geen extra veld maar een toevoeging van de geboortedatum direct bij de naam, al dan niet in kleinere cijfers of via een mouse over. ${ }^{359}$ Belangrijk is dat er meer begrip komt voor de keuzes en mogelijkheden van programmeurs en zorgverleners rond eAfspraak. 


\subsubsection{DE SACRALE VORMEN VAN PAZIO EN LRJG}

PAZIO en LRJG hebben ieder een eigen sacrale vorm. Anders dan bij PAZIO staat bij LRJG niet de vrijheid van de patiënt centraal maar het verlenen van goede zorg. Er is een dan ook een spanning tussen sacrale vormen van PAZIO en LRJG. Die spanning zien we terug in het implementatieproces.

PAZIO is bedoeld om 'een beetje vrijheid' te geven, zoals mevrouw De Wolf het zegt in de PAZIO-promotiefilm. In diezelfde film vertelt LRJG-huisarts Hollander dat PAZIO voor de eerstelijnszorg zorgverleners een paraplu is die de communicatie tussen zorgverlener en patiënt kan verbeteren, ${ }^{360}$ ofwel: met deze innovatie willen we de behandelrelatie verbeteren. LRJG wil met PAZIO een digitale behandelrelatie ontwikkelen om de zorg te verbeteren.

PAZIO en LRJG hebben verschillende idealen die ze nastreven, maar doen dat met hetzelfde middel: technologie. Technologische innovatie is onderdeel van zowel de sacrale vorm van PAZIO als die van LRJG. LRJG streeft als academische eerstelijnspraktijk niet alleen naar het bieden van uitstekende gezondheidszorg, maar ook naar verbetering van die zorg door innovatie. ${ }^{361}$ De artseneed, wetgeving en geschiedenis van de eerstelijnszorg, laten zien dat in de eerstelijnszorg in het algemeen en in LRJG-praktijk in het bijzonder alles gericht is op het verlenen van goede zorg. Daarin ligt haar bestaansrecht, haar streven; dat is de kern van het primaire proces. Om die goede zorg te realiseren worden drie zaken net zo vanzelfsprekend als essentieel geacht:

1) De vertrouwelijkheid van de behandelrelatie;

2) Zorgvuldige inzet van medische kennis;

3) Verbetering door kennisontwikkeling en innovatie.

In de academische eerstelijnspraktijk van LRJG staan deze drie buiten kijf, ze zijn een gegeven en geven richting aan het denken en doen. Vanuit het TIM zijn dit identiteitsbepalende waarden. Het zijn waarden die vanzelfsprekend en niet onderhandelbaar zijn binnen de praktijk. In termen van Durkheim vormen ze de kern van het geloof van LRJG, ze verwoorden het sacrale in de eerstelijnspraktijk LRJG. 


\subsubsection{TWEE SACRALE VORMEN IN ÉÉN PRAKTIJK}

In de ontwikkeling van PAZIO kregen haar sacrale waarden en overtuigingen tot nu toe vooral vorm in geloofsverhalen, verwachtingen en uitgesproken idealen. Die werden zichtbaar en ontwikkelden zich in notities, presentaties en de promotiefilm. Het sacrale werd vooral verwoord en verbeeld. Binnen LRJG zijn er zeker ook documenten en beelden die de sacrale waarden verhalen, verbeelden en vast leggen. Denk bijvoorbeeld aan de artseneed, de WGBO en het idee van een academische praktijk. In de dagelijkse zorgpraktijk van LRJG spelen dergelijke documenten echter een weinig actieve rol. Het zijn vanzelfsprekende kaders op de achtergrond die weinig expliciet benoemd worden in het dagelijks werk. Het sacrale zit hier niet in de verhalen over idealen, maar in het vanzelfsprekend handelen in praktijk. Er zitten immers nog patiënten in de wachtkamer en die moeten geholpen worden. Zo krijgt het sacrale in de praktijk steeds opnieuw vorm. Goede zorg is een vanzelfsprekende waarde maar vooral een activiteit die al decennialang richting geeft aan de traditie van de zorg. Dat is wat richting geeft aan de ontwikkeling van de procedures en routines rond PAZIO.

Hieronder zal ik laten zien hoe de ontwikkeling van de routines en procedures rond PAZIO steeds gericht is op het vormgeven van goede zorg, waarbij de behandelrelatie en medische kennis richting geven aan de innovatie. Met een Durkheimiaanse blik wordt zichtbaar dat we de beschreven routines en procedures beter kunnen begrijpen als rituelen. De procedures en routines staan immers niet op zichzelf maar zijn onderdeel van een geheel waarin alles gericht wordt op de sacrale goede zorg die gestalte krijgt in de behandelrelatie, het gebruik van medische kennis en werken aan innovatie. Aandacht voor het sacrale en rituele helpt om het implementatieproces van PAZIO bij LRJG, de keuzes en combinaties die daarin gemaakt worden te begrijpen.

\subsubsection{KIEZEN VOOR DE ONGEMAKKELIJKE WEG}

\section{Portaalintegratie}

Een belangrijke voorwaarde van LRJG voor het gebruik van PAZIO is de integratie van het huisartseninformatiesysteem. Het HIS is het centrale systeem in de praktijk, daar moet alle informatie rondom de behandelrelatie ingaan en uitkomen. Als er geen integratie met het HIS is, moet de informatie handmatig in het systeem gezet worden en er ook handmatig uitgehaald worden. Dat levert de zorgverleners een flinke hoeveelheid extra knip-en-plak werk op. Dat is onpraktisch en onwenselijk. Gesteld voor de keus tussen HIS- of Portaal-integratie om Julius Online te ontsluiten kiezen alle zorgverleners voor Portaal-integratie. Dat 
is moeilijk te begrijpen als we denken in termen van het eigenbelang van de zorgverleners. Ze zadelen zichzelf immers met extra werk op, zonder dat ze daar extra tijd, geld of andere beloning voor krijgen. Als we echter, naast de profane aspecten, oog hebben voor de sacrale dimensie van de zorg worden de keuzes en overwegingen wél inzichtelijk. De keuze voor Portaal-integratie en het extra werk dat dat oplevert is een investering in de digitalisering van de behandelrelatie. De behandelrelatie is een sacraal element in de praktijk, ze is gericht op het realiseren van goede zorg. Daarvoor is men bereid extra werk te doen.

Het werk dat Portaal-integratie met zich meebrengt voor de zorgverleners is weliswaar aanzienlijk maar gebeurt buiten het zicht van de patiënt. Het is praktisch werk dat tijd van de zorgverleners vraagt, dat is te rechtvaardigen omdat het bijdraagt aan de kwaliteit van de zorg en behandelrelatie. Het alternatief is HIS-integratie met een uitgestelde Portaal-integratie. Dat zou betekenen dat de patiënt voor zijn digitale behandelrelatie gebruik moet maken van twee verschillende portalen, namelijk PAZIO en het MGn-portaal van PharmaPartners. Dat geeft voor de patiënt versnippering van de digitale behandelrelatie en een onoverzichtelijke en veranderende digitale ondersteuning daarvan. Het bespaart de zorgverleners weliswaar werk, maar doet afbreuk aan de kwaliteit van zorg en de behandelrelatie. Het levert praktisch een groot afbreukrisico op voor het gebruik van de digitale schil. Het is bovendien fundamenteel een doorkruising van de waarde die gehecht wordt aan een goede en stabiele behandelrelatie. Een dergelijke afbreuk van kwaliteit past dan ook allerminst in de traditie van de eerstelijnszorg. Het gemak waarmee de LRJG-zorgverleners kiezen voor Portaal-integratie is goed te begrijpen als we oog hebben voor het sacrale van de behandelrelatie in de zorgpraktijk. LRJG kiest voor Portaal-integratie omdat ze hecht aan service aan de patiënt en een optimale digitale behandelrelatie voor de patiënt, om zo goede zorg te realiseren. Dat is de sacrale basis waarop de rituelen gericht worden.

\section{Authenticatie}

Niet alleen zorgverleners moeten voor de rituelen extra werk verrichten, ook de patiënt zal moeten bijdragen. Bij het authenticatieproces zagen we al dat men DigiD als een noodzakelijk kwaad beschouwt, om het goede te bereiken. Het kwaad schuilt in het extra werk voor de patiënt, die daardoor zou kunnen afhaken in het tot stand komen van de digitale behandelrelatie. Het gebruik van DigiD wordt echter noodzakelijk geacht -en wettelijk verplicht gesteld- om in de digitale behandelrelatie zeker te weten met wie men van doen heeft. DigiD is een erkende veilige en betrouwbare authenticatie methode, maar ook één die niet eenvoudig is 
in het gebruik. Waar LRJG met de Portaal-integratie zonder meer voor gemak en duidelijkheid in de behandelrelatie voor de patiënt koos, kiest ze ook hier voor de kwaliteit van behandelrelatie door de prioriteit in dit geval te leggen bij vertrouwen en zorgvuldigheid, ondanks dat dit ten koste gaat van het gemak voor de patiënt. Zo wordt een digitaal authenticatie-ritueel opgebouwd waardoor de zorgverlener weet wie hij digitaal tegenover zich heeft en de patiënt toegang krijgt tot een eenduidig en overzichtelijke digitaal portaal.

\section{eAfspraak}

Het implementatieteam wil met eAfspraak de digitale behandelrelatie versterken met een nieuwe service voor de patiënt. De module eAfspraak is weinig medisch inhoudelijk, maar heeft wel degelijk consequenties voor de zorg-en behandelrelatie. Via eAfspraak kan de patiënt bij een klacht op elk moment en overal een afspraak maken. Dat moet de patiënten comfort geven als ze zich buiten openingstijden zorgen maken en biedt hun te allen tijde de mogelijkheid een afspraak te plannen bij het gezondheidscentrum. eAfspraak brengt zo comfort en service voor de patiënt, maar tegelijkertijd geeft het de zorgverleners in de praktijk een extra aandachtspunt in de hectiek van de opening van de praktijk in de ochtend.

In de stand alone versie van eAfspraak moeten vooral de assistenten zich nieuwe rituelen eigen maken voor de omgang met tijd en de agenda. Dat ze daartoe bereid zijn is niet te begrijpen vanuit hun eigen belangen of werkprocessen. eAfspraak levert de zorgverleners vooral extra gedoe op. Dat ze dat gedoe voor lief nemen is wel te begrijpen als we oog hebben voor het sacrale. Voor de zorgverleners is eAfspraak niet zozeer een poging om efficiënt of effectief te werken, het draait hier niet primair om tijd en geld. Met eAfspraak wordt een nieuwe service aan de patiënt geleverd en daarmee wordt gewerkt aan de digitale behandelrelatie. Die behandelrelatie is van een andere orde dan het profane denken in termen van tijd en geld. Dat betekent niet dat tijd, geld en andere profane zaken hier geen rol spelen maar ze zijn in deze situatie niet de norm noch allesbepalend of richtinggevend. De behandelrelatie is een doel op zich en heeft een sacrale intrinsieke waarde. Daar zetten de zorgverleners zonder problemen extra stappen voor. De zorgverleners werken met al het extra gedoe aan een ritueel waarmee de sacrale behandelrelatie en goede zorg benaderd kunnen worden.

\subsubsection{WORSTELEN MET HET SACRALE}

De zorgverleners van het LRJG blijken bereid om extra werk te verrichten om de benodigde rituelen voor de digitale behandelrelatie te realiseren. Niet alles is echter op te lossen met extra werk. Sacrale rituelen komen tot stand met profane middelen als tijd, geld, mensen en middelen 
en die kennen schaarste. Dat wordt goed duidelijk in de ontwikkeling van rituelen voor het eConsult. Daarbij loopt het sacrale tegen profane grenzen aan.

\section{Profane grenzen}

Het tarief dat een zorgverzekeraar vergoed voor een eConsult is $€ 4,56 .{ }^{362}$ Omgerekend betekent dit dat een zorgverlener 5 minuten tijd krijgt om een eConsult te beantwoorden. Dat is de context en een gegeven voor zorgverleners en gezondheidscentra als het LRJG. Ook in de zorg geldt: tijd is geld. Het sacrale streven naar goede zorg en de ideale behandelrelatie loopt in de praktijk tegen de profane financieringskaders aan, die niet meer opgelost kunnen worden met het zetten van een stapje extra. Voor een duurzame bedrijfsvoering moeten tijdskaders worden opgesteld die wellicht zorginhoudelijk en voor de behandelrelatie niet ideaal zijn. De zorgverleners worstelen met de uitdaging om binnen de profane grenzen van een duurzame bedrijfsvoering een ritueel voor eConsult in te richten. De oplossing wordt gevonden in het beperken van het tekstvak van het eConsult tot een maximum aantal tekens en in de handleiding te vermelden dat de patiënt één vraag per online consult kan stellen.

\section{Sacrale grenzen}

Het eConsult kent niet alleen profane grenzen, maar ook sacrale grenzen als het gaat om het realiseren van goede zorg en een betrouwbare behandelrelatie. Het eConsult is niet geschikt voor alle zorgvragen. Voor spoedeisende vragen is het eConsult niet geschikt, daarvoor moet de patiënt telefonisch contact opnemen. Psychische problematiek is in de regel ook niet geschikt voor eConsult, het heeft de voorkeur om daarvoor een afspraak te maken en een zorgverlener te spreken. Dergelijke zorginhoudelijk gerelateerde zaken zijn moeilijk te programmeren in het eConsult zelf. Ze worden daarom tekstueel toegevoegd aan het ritueel. Er wordt een waarschuwing geplaatst bij het openen van eConsult dat deze niet geschikt is voor spoedeisende zaken. Daarnaast wordt in de handleiding, die als pdf beschikbaar is, een opmerking geplaatst over psychiatrische klachten.

\section{Nieuwe rituelen, nieuwe zorg}

Nieuwe rituelen brengen nieuwe verwachtingen van patiënten met zich mee. Dat wordt goed zichtbaar in de rituelen voor het eConsult. Van patiënten wordt verwacht dat ze één klacht kort en krachtig beschrijven. 
Dat ze het eConsult-ritueel niet gebruiken voor spoedeisende of psychiatrische problematiek. Dat ritueel vraagt van de patiënt een flinke mate van digivaardigheid, taalvaardigheid, het vermogen om hoofd- en bijzaken te onderscheiden en snel tot de kern van de zaak door te dringen. Het eConsult is daarmee niet alleen een andere manier van communiceren het is ook een andere manier van zorgverlening en denken over wat goede zorg is. Het eConsult ritueel hervormt de rol van de participanten, de behandelrelatie, maar ook de invulling van goede zorg. Het sacrale zelf krijgt in de digitalisering van de praktijk een nieuwe invulling. De huisartsenzorg werd in het Woudschotenrapport (1963) afgebakend als continue, integrale en persoonlijke zorg. ${ }^{363}$ De integrale zorg aan patiënten krijgt in tijden van digitalisering een nieuwe invulling.

\section{Persoonlijke zorg}

Het vormgeven aan persoonlijke zorg vraagt in de ontwikkeling van het eConsult om aandacht. Voor de zorgverlener wordt door middel van het authenticatieritueel duidelijk met welke patiënt zij of hij van doen heeft. Het blijkt echter nog niet zo eenvoudig om omgekeerd ook de patiënt helderheid te geven over welke zorgverlener het eConsult beantwoordt.

In het implementatieteam hecht men eraan dat de patiënt zijn zorgverlener kan selecteren en dat deze idealiter dan ook reageert op het online consult. Die wens voor een persoonlijke behandelrelatie is invoelbaar. Zorgverlener en patiënt kunnen zo immers een medisch intieme relatie opbouwen en dat draagt bij aan een vertrouwde behandelrelatie en aan goede zorg. Met het streven naar die persoonlijke behandelrelatie wordt het ritueel gericht op het sacrale van de LRJGpraktijk. Tegelijkertijd is de gedachte achterhaald dat persoonlijke zorg betekent dat een een op een relatie wordt opgebouwd. Desondanks hechten de zorgverleners in het implementatieteam nog steeds waarde aan het beantwoorden van de eConsult door de eigen zorgverlener, het is nog steeds onderdeel van hun ideaal van persoonlijke zorg en de aard van een goede behandelrelatie. ${ }^{364}$ Dit blijft dan ook een richtinggevend ideaal voor het eConsult, ondanks het feit dat het ritueel van het consult in de spreekkamer er niet meer op ingericht is.

Voor het implementatieteam is het inrichten van het eConsult een worsteling met zorgidealen en met sacrale en profane grenzen. Het lukt in de praktijk niet om het ritueel zo vorm te geven dat de patiënten van 
de door hen geselecteerde zorgverlener een reactie op hun online consult krijgen. Toch blijft de mogelijkheid voor patiënten om zelf hun zorgverlener te selecteren bij een eConsult in stand, het sacrale wordt niet opgegeven maar op een andere wijze benaderd in het ritueel. De oplossing is dat de patiënten zelf hun zorgverlener kunnen selecteren aan wie het online consult gericht wordt. In de handleiding bij het eConsult wordt echter gemeld dat het desondanks mogelijk is dat een andere zorgverlener reageert. Zo wordt het sacrale van de persoonlijke behandelrelatie op symbolisch wijze hooggehouden, zonder dat het in de praktijk wordt gerealiseerd.

\subsubsection{SACRALE VERKLARINGEN}

In het technologieonderzoek worden implementatieprocessen beschreven als socio-technische ontwikkeling. De technologie en praktijk moeten op elkaar worden afgestemd en zich hand in hand ontwikkelen. Er wordt gesproken van een co-constructie of co-productie ${ }^{365}$ proces waarin technologie en praktijk met elkaar verweven raken en, in termen van SCOT, de betekenisflexibiliteit afneemt en stabilisering plaatsvindt. In de PAZIO-film wordt PAZIO als omnipotent gepresenteerd. We zagen in de bespreking van de film in hoofdstuk 3 al dat de idealen in de film onderlinge tegenstrijdigheden kennen, in de praktijk is die omnipotentie dan ook niet te realiseren. In de PAZIO-film is de betekenisflexibiliteit van PAZIO nog hoog, in het implementatieproces neemt die aanzienlijk af: PAZIO wordt een digitale schil om de praktijk en daarmee een service aan de patiënt. Hoe kunnen we de richting van dit stabiliseringsproces begrijpen, waardoor wordt ze gedreven?

Vanuit SCOT wordt hierop geen antwoord gegeven. Het technologieonderzoek heeft een scherp oog voor de actoren en factoren in veranderprocessen, maar beschouwt het proces als een ongericht en contingent proces. Daarmee wordt weliswaar Whig-history ${ }^{366}$ voorkomen, maar raken ook zaken idealen, tradities en overtuigingen uit zicht en ontstaat een blinde vlek voor het verklaren van richting. Met behulp van Durkheims benadering van het sacrale kunnen we weer oog krijgen hoe het veranderproces richting krijgt, zonder dat er een externe teleologische verklaring gegeven wordt. Het sacrale vestigt de aandacht op de rol van geloofsovertuigingen en grondmotieven en hun verwevenheid met rituelen in de veranderdynamiek in een praktijk. 
PAZIO en LRJG delen een geloof in innovatie, maar geven aan die innovatie in de praktijk en inhoudelijk een ander accent en richting. PAZIO wordt geïmplementeerd bij LRJG, moet zich in die praktijk bewijzen en zich dus verhouden tot sacrale waarden en overtuigingen van LRJG. LRJG heeft in het implementatieproces het heft in handen. Zij ontwikkelen met PAZIO binnen hun praktijk een digitale behandelrelatie. LRJG stelt dan ook een implementatieteam samen. Dat team wordt door PAZIO weliswaar ondersteund door de inzet van een implementatiebegeleider, maar dat neemt niet weg dat PAZIO in het implementatieproces van LRJG verder weinig formele zeggenschap heeft. De ontwikkelaars van PAZIO moeten hun geesteskind hier meer dan ooit loslaten.

In de praktijk verdwijnt de betekenisflexibiliteit van het omnipotente PAZIO met het ontstaan van een functioneel gebruik van PAZIO in de praktijk. Dat gebeurt hand in hand met de ontwikkeling van de rituelen voor de toepassingen die gericht zijn op het sacrale, ofwel de behandelrelatie en goede zorg. Dat sacrale moet gerealiseerd worden met profane middelen. Profane zaken als tijd, ruimte, mensen, verhalen en materialen moeten zo worden georganiseerd en gecombineerd dat rituelen ontstaan waarmee het sacrale in de praktijk benaderd kan worden. Die nieuwe rituelen voor de digitale behandelrelatie beginnen niet bij nul, ze bouwen voort op de bestaande traditie van zorgverlening en behandelrelaties in de eerste lijn. Met de implementatie van PAZIO wordt gewerkt aan de constructie van een digitale behandelrelatie binnen LRJG.

De rituelen maken het sacrale in de praktijk benaderbaar. Ze vormen activiteiten gericht op de sacrale behandelrelatie en goede zorg. De rol van het sacrale in het ritualiseren van de digitale behandelrelatie wordt goed zichtbaar in de ontwikkeling van Julius Online. Ze verklaart dat de zorgverleners bij LRJG kiezen voor het gedoe dat Portaal-integratie, authenticatie met DigiD en eAfspraak met zich meebrengen en het maakt de worsteling met de zorgverlenerskeuze rond het eConsult begrijpelijk.

\subsubsection{DE SACRALE VORM VAN PAZIO EN DE PRAKTIJK VAN LRJG}

Rituelen zijn onmisbaar om het sacrale te benaderen, ook in de zorgpraktijk. Opvallend is dat de sacraliteit die in het project PAZIO ontstond, binnen de LRJG-praktijk niet of nauwelijks wordt uitgewerkt in rituelen. Daar leven andere sacrale idealen. In de LRJGpraktijk gelooft men primair in het verlenen van goede zorg, door de inzet van wetenschappelijke inzichten en innovatieve technologische mogelijkheden en de opbouw van een goede behandelrelatie. Daartoe wordt PAZIO geïmplementeerd, ingericht en ingezet in de praktijk. PAZIO en LRJG delen het geloof in innovatie. Waar PAZIO het 
accent legt bij de vrijheid van en regie door de patiënt, streeft LRJG met innovatie naar het ontwikkelen van de behandelrelatie waarin de zorgverlener een minstens zo belangrijke stem heeft.

Een ander verschil tussen het sacrale bij LRJG en PAZIO zit niet in de inhoud maar in de vorm. Bij PAZIO komt het sacrale primair tot uitdrukking in de vorm van geloof. Er worden presentaties gegeven, notities geschreven en zelfs een missionaire film over PAZIO gemaakt. Bij LRJG is het geloof niet zo uitgesproken, het lijkt eerder een geïnternaliseerd vanzelfsprekend gegeven. Dat betekent niet dat dit geloof niet helder is. De geneeskundige eed valt te lezen als een medische dogmatiek. Die dogmatiek hoeft echter niet steeds opnieuw beleden te worden, de ambitie is om deze in de praktijk te realiseren: daartoe worden rituelen ontwikkeld. 


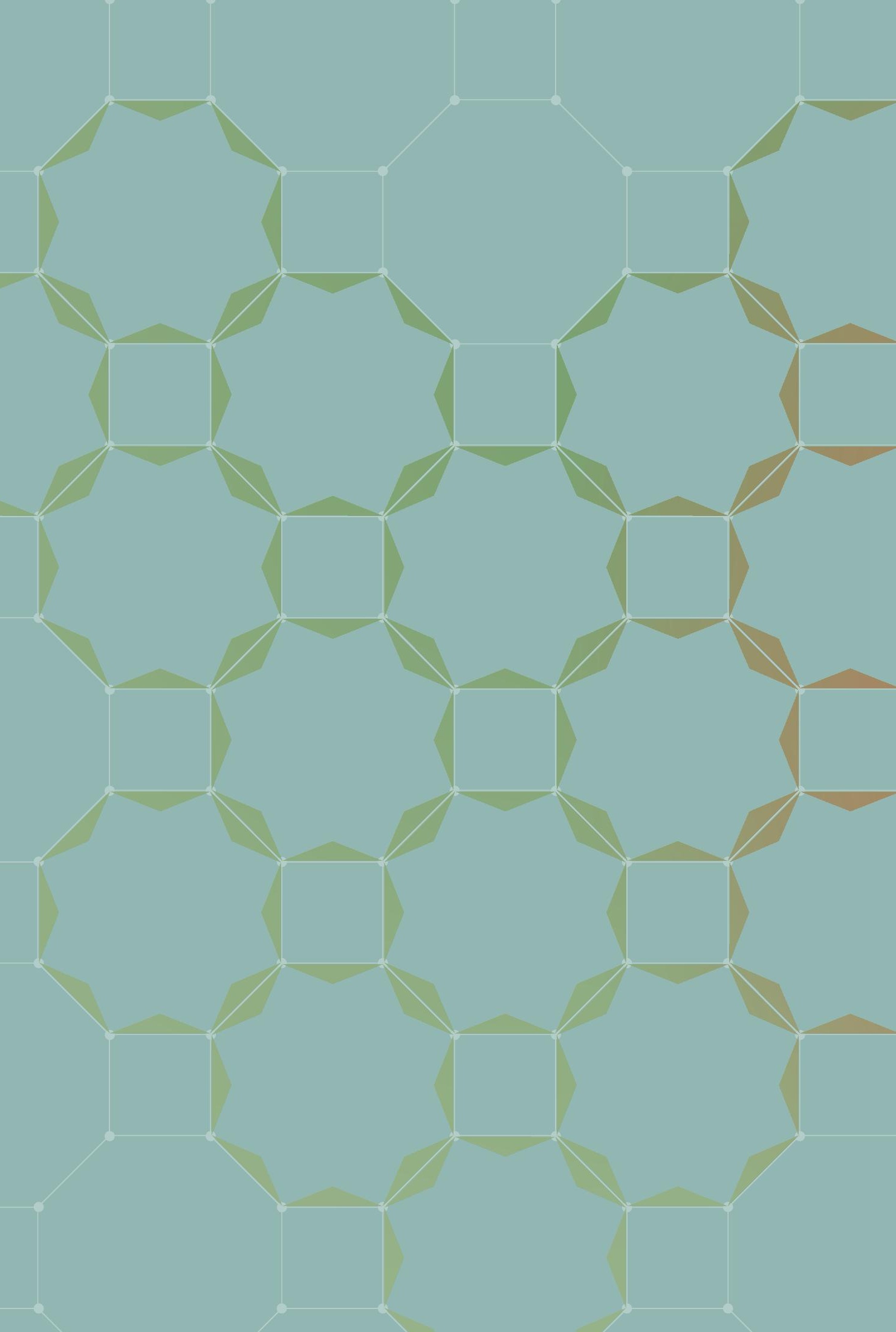





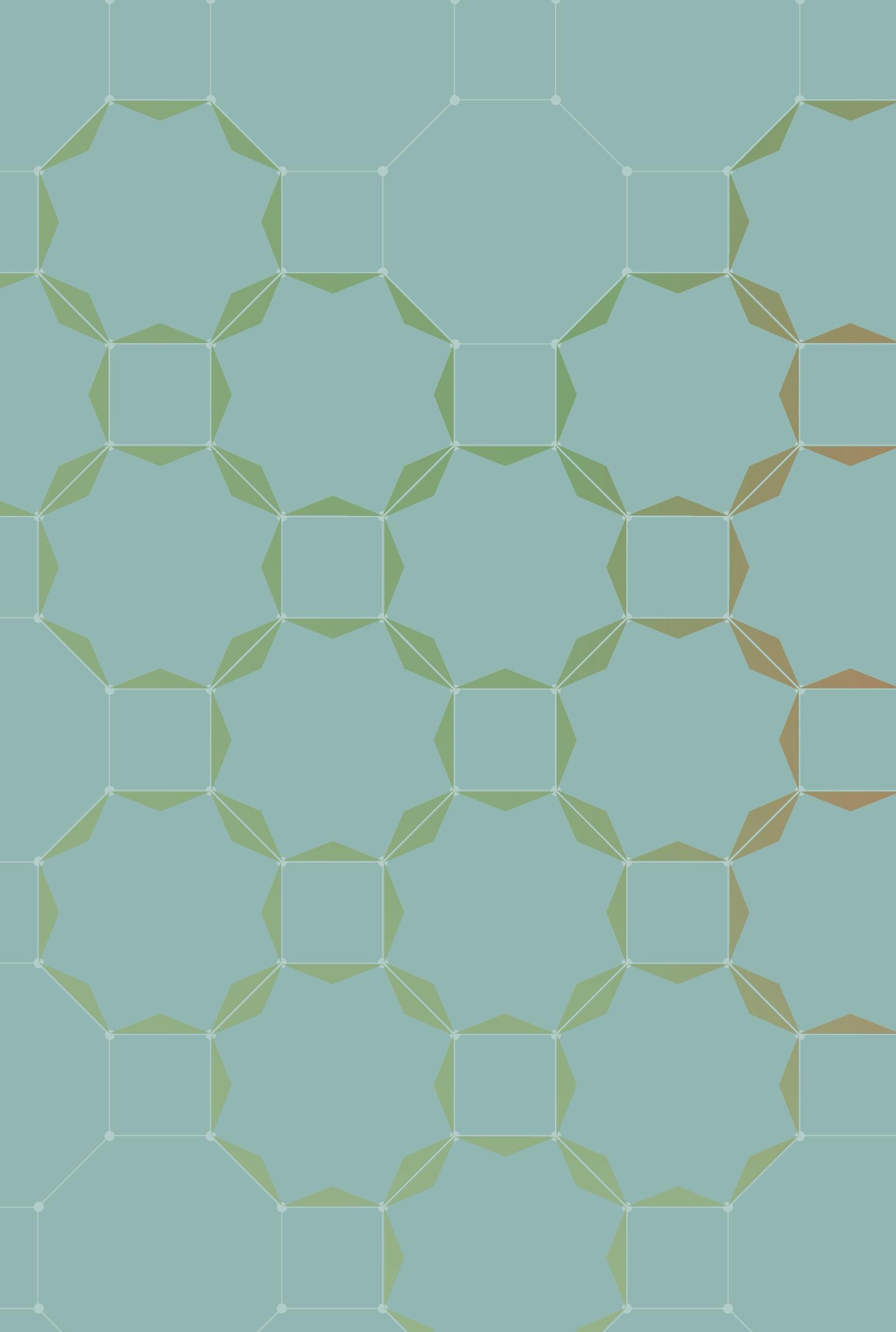




\section{DE DYNAMIEK VAN SOCIALE VERBANDEN EN SACRALE VORMEN}

\subsection{INLEIDING}

In hoofdstuk 3 en 4 werden twee manifestaties van de sacrale vorm rond PAZIO uitgelicht: allereerst het geloof en vervolgens de rituelen rond PAZIO. In dit hoofdstuk ligt de focus op de derde manifestatie van het sacrale, namelijk de morele gemeenschap. Er wordt geanalyseerd hoe de ontwikkeling van PAZIO verweven is met de ontwikkeling van de sociale verbanden en sacrale vormen rond PAZIO.

Om de ontwikkeling van de sociale verbanden rond PAZIO te bestuderen maak ik gebruik van het concept Relevante Sociale Groep (RSG) zoals dat in SCOT geïntroduceerd is en het begrip gemeenschap zoals dat bij Durkheim gebruikt wordt. De combinatie van die twee begrippen maakt het mogelijk om de dynamiek tussen eenheid en verscheidenheid in sociale verbanden te analyseren en om oog te krijgen voor verandering en stabiliteit. RSG is immers een concept dat ontwikkeld is om inzicht te krijgen in socio-technische veranderingen, terwijl Durkheim het begrip morele gemeenschap juist inzet om sociale stabiliteit te begrijpen vanuit een sacraal perspectief.

Sacrale vormen onderscheiden zich van het alledaagse of het profane. Het sacrale is van een andere orde, zoals beschreven in hoofdstuk 2. Tegelijkertijd wordt het sacrale gevormd met profane middelen. Het sacrale manifesteert zich in geloof, rituelen en gemeenschap en is een emergente grootheid. Het ontstaat in een samenspel van deze drie en geeft richting aan ontwikkelingen. In de analyse zal ik de dynamiek van het sacrale 
onderzoeken en daarbij aandacht geven aan zowel de constructie van de sacrale vorm als aan haar richtinggevende rol.

In hoofdstuk 3 en 4 werden specifieke perioden in de PAZIO-probe onderzocht, namelijk de co-constructie van geloof en technologie en het ritualiseren van de technologische praktijk. In dit hoofdstuk kijk ik terug naar de gehele probe. Dat maakt het mogelijk om de dynamiek in de ontwikkeling en de rol van het sacrale daarin te bestuderen. Ik onderscheid daarbij drie perioden (zie kader en de tijdlijn in de bijlage). In elk van die perioden is een fase van verandering en een fase van stabilisatie te onderscheiden. In de fase van verandering is sprake van vernieuwing in het denken en doen en betreden nieuwe relevante sociale groepen met eigen interpretaties het speelveld. In de fase van stabilisatie wordt vanuit de verscheidenheid van spelers en interpretaties gewerkt aan de vorming van een gemeenschap en een gezamenlijke basis voor het verder werken aan PAZIO.

\section{- PERIODISERING IN DE PAZIO-PROBE}

Periode 1: Een gemeenschappelijk plan voor het project PAZIO

1. Verandering 1: De ideale richting vinden vanuit particuliere perspectieven

2. Stabilisatie 1: Een ontluikende sacrale vorm rond de naam en het logo van PAZIO

Periode 2: Steun voor een omnipotent portaal en de iconische patiënt

1. Verandering 2: Een missionaire gemeenschap op zoek naar morele en materiele steun

2. Stabilisatie 2: Mevrouw De Wolf en PAZIO vormen de sacrale vorm

Periode 3: Het portaal in de praktijk

1. Verandering 3: Profane strijd rond sacrale zaken in de praktijk

2. Stabilisatie 3: Rituelen voor de digitale behandelrelatie 


\subsection{PERIODE 1: EEN \\ GEMEENSCHAPPELIJK PLAN \\ VOOR HET PROJECT PAZIO}

\subsubsection{VERANDERING 1: DE IDEALE RICHTING VINDEN VANUIT PARTICULIERE PERSPECTIEVEN}

De eerste relevante sociale groep in de ontwikkeling van PAZIO is een clubje bevlogen mannen met inspiratie voor innovatie. A. Dekker, Torenbeek, Rietveld en Knoop hebben een idee voor een Patiëntgebonden Virtuele Zorginfrastructuur en werken eraan om dat idee verder te ontwikkelen en te realiseren. Zij vormen met elkaar Mediportaal, een klein bedrijfe voor ICT in de zorg, onder de hoede van het grote Universitair Medisch Centrum Utrecht. Het UMCU biedt hen de context en faciliteiten om tot een idee te komen en uit te werken. Het biedt hen ook een cultuur met een eigen sacrale vorm: in het UMCU staan medische zorg, onderzoek en innovatie hoog in het vaandel. ${ }^{367}$ De medewerkers van Mediportaal achten de realisatie van de Patiëntgebonden Virtuele Zorginfrastructuur (PVZ) alleen mogelijk als grotere spelers in de zorgmarkt en belangenorganisaties met elkaar samenwerken in plaats van elkaar beconcurreren. Daarbij zou een grote relatief neutrale kennisorganisatie als UMC Utrecht geschikt zijn om de kar te trekken. ${ }^{368}$ In de ontwikkeling van PAZIO is geen sprake van mythische innovatieve individuen, zoals die in meer romantische verhalen graag geschetst worden ${ }^{369}$, het is een gemeenschappelijke ontwikkeling waarin vele partijen betrokken zijn. Dat neemt niet weg dat deze mannen daar en op dat moment het ankerpunt zijn voor de ontwikkeling van wat PAZIO zal worden. Zij ontwikkelen het idee en zetten het op papier zodat hun opdrachtgevers en beoogde partners zich een beeld kunnen vormen van een mogelijk innovatieproject.

Naast deze geïnspireerde enthousiastelingen is een klein netwerk van partijen en personen betrokken, die elkaar al goed kennen vanuit het UMCU-netwerk. Die relevante sociale groepen hebben allen een eigen PVZ-perspectief. Dat perspectief komt voort uit hun particuliere ambities en doelen bij het ontwikkelen van het PVZ. Met behulp van het

367 Klijn, Verlangen naar verbetering.

368 Rietveld en Mediportaal, Voorstel "Patiëntgeoriënteerde Virtuele Zorginfrastructuur". Tekstdocument, 9 november 2006,2

369 Denk bijvoorbeeld aan Isaacson, Steve Jobs; Vance, Elon musk; Burgan en Hammond, Who is Richard Branson? Voor een meer genuanceerd en empirisch onderbouwd verhaal over de rol van het individu in innovatie zie Bijker, of bicycles, bakelites, and bulbs, 101-98. 
Triple I Model van Verkerk kunnen we de in hoofdstuk 3 geïntroduceerde perspectieven op het PVZ duiden vanuit de identiteit van de relevante sociale groepen (zie tabel 5.1).

\begin{tabular}{|l|l|l|l|}
\hline $\begin{array}{l}\text { RELEVANTE } \\
\text { SOCIALE GROEP }\end{array}$ & IDENTITEIT & PRIMAIR PROCES & PVZ-PERSPECTIEF \\
\hline UMCU & Moreel-analytisch & Zorg en onderzoek & $\begin{array}{l}\text { Zorg en onderzoek in de } \\
\text { regio }\end{array}$ \\
\hline Mediportaal & Formatief & Zorginnovatie & PVZ realiseren \\
\hline BSL & Economisch & Commercie & Vermarkten praktijkinfo \\
\hline Julius Centrum & Analytisch & Onderzoek & Data verzamelen \\
\hline LRJG & Moreel & Zorg & Zorgkwaliteit \\
\hline VitaValley & Moreel-formatief & Zorginnovatie & $\begin{array}{l}\text { Zelfredzaamheid } \\
\text { patiënten }\end{array}$ \\
\hline
\end{tabular}

TABEL 5.1 Perspectieven op het PVZ van relevante sociale groepen en hun identiteit.

De participanten van het eerste uur ontwikkelen het PVZ voornamelijk met het oog op hun eigen primaire proces. In figuur 5.1 uit de PVZ-notitie zien we dat die participanten in de praktijk veelal zowel leverancier als gebruiker zijn.

De gedachtenvorming over het PVZ wordt in deze fase primair gedreven door de identiteiten van de beoogde participanten, er is nog geen gemeenschappelijk ideaal of verhaal. Wel worden met behulp van het TIM twee richtingbepalende bronnen zichtbaar. Allereerst is het de identiteit van de 'Mediportaalmannen' die met hun ambities en idealen richting geven en zich daadwerkelijk wijden aan de realisatie. Als penvoerders en architecten hebben zij een centrale positie in het project. De tweede richtinggevende bron is de UMCU-context waarbinnen gewerkt wordt. Deze UMCU-context heeft haar eigen grondmotieven, idealen en overtuigingen. Idealen als de patiënt centraal, gezondheidszorg, kennis en innovatie zijn vanzelfsprekende 


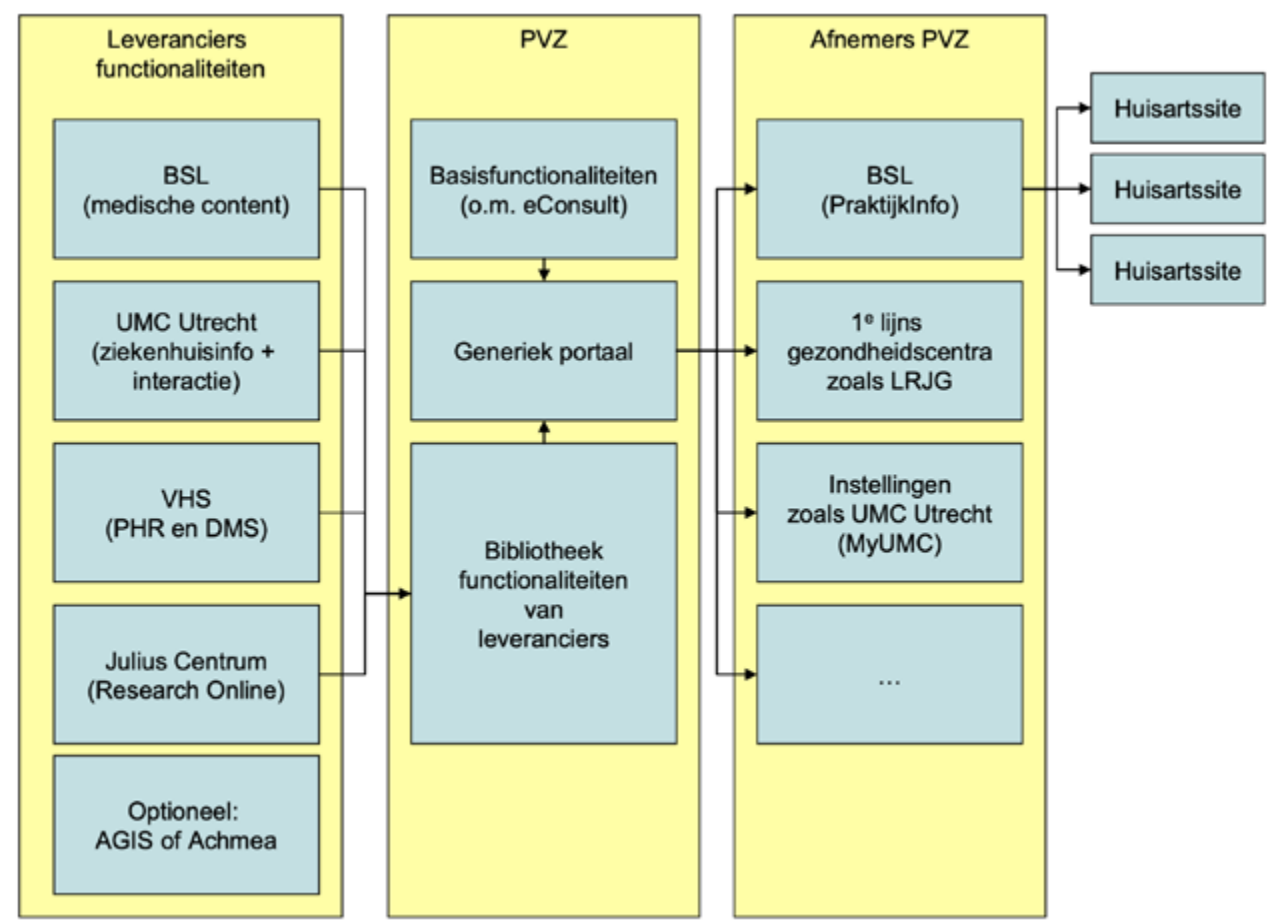

FIGUUR 5.1 Beoogde leveranciers en afnemers van het PVZ.

richtinggevende uitgangspunten.

We kunnen in deze fase nog niet spreken van een uitgekristalliseerde sacrale vorm, maar dat neemt niet weg dat de PVZ een icoon voor de groep wordt waaraan de idealen, de groep en de rituelen zich kunnen hechten en ontwikkelen.

\subsubsection{STABILISATIE 1: EEN ONTLUIKENDE SACRALE VORM ROND DE NAAM EN HET LOGO VAN PAZIO}

Als de perspectieven en ideeën over het PVZ en later PAZIO zich ontwikkelen, rijpt naast een geloof langzamerhand ook een meer congruente organisatie. Na een open innovatieve fase volgt een integratieve fase. De relevante sociale groepen vormen een morele gemeenschap en de particuliere perspectieven monden uit in een gedeeld geloof en een heldere projectopzet. 
Dat integratieproces zien we terug in de programmaopzet waarin een geschiedenis van het ontstaan van het project beschreven wordt. Er wordt allereerst gesproken over 'Partners van het eerste uur'370 dat zijn UMC Utrecht, Mediportaal, Julius Centrum en LRJG, ${ }^{371}$ allen aan het UMCU gelieerde partijen. 'Tijdens het uitwerken van het concept bleek dat een verbreding wenselijk was. Vital Health Software (VHS) werd als partner aangezocht ${ }^{372}$ Vanuit de ambities en richting van het project zijn er genoeg aanleidingen om gericht naar partners te zoeken en deze te vinden. VitalHealth Software is een softwareontwikkelaar gespecialiseerd in ketenzorg en zelfmanagement tools. Ze hebben een 'modern, flexibel en toekomst vast ontwikkelplatform.' ${ }^{373}$ Vanwege hun technische kennis en ervaring worden ze als een waardevolle partner in de PAZIO-samenwerking gezien. Daarnaast 'werd VitaValley bereid gevonden om als financier en investeerder deel te nemen aan het project.' VitaValley wordt ook als een aantrekkelijke partner beschouwd vanwege haar visie op gezondheidszorg: patiënt centraal. ${ }^{374}$ Dat sluit goed aan bij het concept van PAZIO. VitaValley zal ook aansluiten. VitaValley is een expliciet waarden gedreven stichting, die zichzelf toentertijd in de christelijke traditie plaatste. Ze heeft aan de wieg gestaan van de VitalHealth Software, en hoewel dat ondertussen een zelfstandige onderneming is, zijn de banden tussen de twee organisaties hecht. De mensen kennen elkaar, hebben veelal een gedeelde christelijke achtergrond en men ontmoet elkaar op Landgoed Groot Zonneoord in Ede waar beide gehuisvest zijn. VitaValley heeft een identiteitsstatuut opgesteld waarin ze haar visie, missie en waarden expliciteert. ${ }^{375}$

'VitaValley ontwikkelt en levert innovatieve concepten ... voor senioren en gehandicapte medemensen door nieuwe zorgprocessen ..., huisvesting en ICT te combineren tot een samenhangend continü̈m van zorg.... Het optimale behoud van zelfstandigheid en zelfredzaamheid van de doelgroepen in hun eigen woonomgeving staan daarbij centraal. Verder wil VitaValley de ketenzorgontwikkeling ondersteunen middels

370 Dekker en Torenbeek, Programmaopzet PAZ10. Tekstdocument, 27 november 2007, 7.

371 Oorspronkelijk was ook Uitgeverij Bohn Stafleu van Loghum een van de partners van het eerste uur. Dat bedrijf heeft echter 'vanwege interne redenen besloten afstand te nemen.' Zie: Dekker en Torenbeek, Programmaopzet PAZIO. Tekstdocument, 27 november 2007, 7.

372 Dekker en Torenbeek Programmaopzet PAZIO. Tekstdocument, 27 november 2007, 7.

373 Dekker en Torenbeek, Programmaopzet PAZIO. Tekstdocument, 27 november 2007, 7.

374 Dekker en Torenbeek, Programmaopzet PAZIO. Tekstdocument, 27 november 2007, 7.

375 VitaValley, Identiteitsstatuut VitaValley. Tekstdocument, 3 mei 2010. 
nieuwe ICT-applicaties ... en de toepassing van nieuwe technologische hulpmiddelen. Hierbij is niet de techniek het belangrijkst, maar dat wat goed is voor mensen.' ${ }^{376}$

VitaValley vraagt van haar partners respect voor haar visie, maar geeft hen daarbij ruimte om deze op eigen wijze en aanspreekbaar in te vullen. ${ }^{377}$ Met VitalHealth Software en VitaValley worden twee relevante sociale groepen met een uitgesproken identiteit (in de zin van het TIM) aan het project in de UMCU-context toegevoegd.

In de programmaopzet van PAZIO wordt gesproken over een gedeelde visie:

'Waarom willen de partners PAZIO samen vormgeven? De partners zijn ieder binnen hun eigen discipline actief met gezondheidszorg en zijn tevens initiatiefrijk om de innovatie ervan te bevorderen. Zij delen voor een groot deel dezelfde visie op gezondheid en ziekte en hebben allen dezelfde doelen en bijdragen aan de gezondheidszorg op het oog:

- Het gezond houden van burgers;

- Het beter maken van patiënten met behulp van evidence based medicine;

- Het op deze wijze (bijdragen aan) een hogere kwaliteit van zorg en leven;

- Het zich onderscheiden op de markt door maatschappelijk (verantwoord) te ondernemen.' ${ }^{378}$

Waar in de plannen voor het PVZ nog de particuliere perspectieven van de relevante sociale groepen werden opgetekend, wordt hier gesproken van een gedeelde visie. De particuliere perspectieven worden zowel inhoudelijk als sociaal veralgemeniseerd. Er vindt daarmee co-constructie van geloof en gemeenschap plaats. Daarnaast worden ook de meer particuliere belangen van de stakeholders erkend. De verschillende stakeholders en hun belangen worden in één matrix gepresenteerd (zie fig. 5.2). Door deze wijze van presenteren wordt duidelijk dat er weliswaar verschillende belangen zijn, maar dat deze niet concurrerend zijn. Het zijn gedeelde belangen zijn die prima in één kader passen. Hier heerst éénheid in verscheidenheid. 


\begin{tabular}{|c|c|c|c|c|c|c|c|}
\hline Partij & 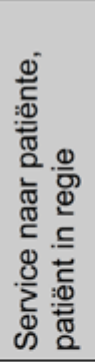 & 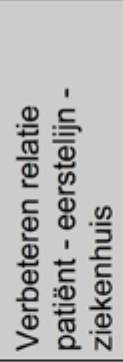 & 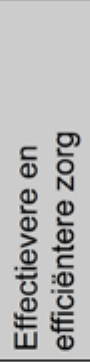 & 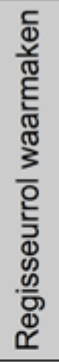 & 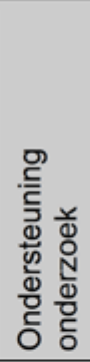 & 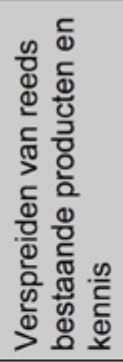 & 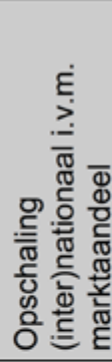 \\
\hline Patiënten/cliënten & $x$ & $x$ & $x$ & & & & \\
\hline UMC Utrecht & $x$ & $x$ & $x$ & $x$ & $x$ & $x$ & \\
\hline Mediportaal & $x$ & & $x$ & & & $x$ & $x$ \\
\hline LRJG & $x$ & $x$ & $x$ & & $x$ & & \\
\hline VHS & $x$ & & $x$ & & & $x$ & $x$ \\
\hline VitaValley & $x$ & & $x$ & & & $x$ & \\
\hline Verzekeraars & $x$ & & $x$ & & & & \\
\hline Locale overheden & $x$ & & $x$ & & & & \\
\hline
\end{tabular}

FIGUUR 5.2 Stakeholderbelangen. ${ }^{379}$

De informele samenwerking tussen de betrokken partijen vanuit het UMCU wordt geformaliseerd op het moment dat er externe partijen toetreden. Naast de programmaopzet wordt er een convenant ${ }^{380}$ opgesteld dat de participanten met elkaar ondertekenen. Daarmee committeren de partijen zich aan elkaar en aan het project en vormen ze een nieuw verband onder de vlag PAZIO.

VitaValley voert vervolgens namens PAZIO gesprekken met de technische dienstverlener Imtech over hun belangstelling om te participeren in PAZIO. Imtech treedt kort daarna toe als partner. Ook die samenwerking wordt geformaliseerd, dit keer door een addendum bij het convenant op te stellen. ${ }^{381}$ Imtech opteert voor een technische rol als bouwer van het portaal. Daarmee beschouwt het PAZIO-consortium zichzelf als compleet. 
$\mathrm{Na}$ de formalisatie op papier via het convenant wordt de betrokkenheid bij elkaar ook in de organisatorische praktijk bevestigd. In lijn met de programmaopzet wordt er een stuurgroep geformeerd waarin alle participerende organisaties een afgevaardigde hebben. ${ }^{382}$ Met de stuurgroep wordt de harde kern van de PAZIO-samenwerking georganiseerd en ontstaat de eerste formele en zichtbare PAZIO-gemeenschap. Als A. Dekker in de stuurgroepvergadering van 26 november 2007 terugkijkt naar het voorgaande jaar, stelt hij vast 'dat de echt betrokken partijen nu om tafel zitten.' 382

De stuurgroep is opdrachtgever voor het programma PAZIO en daarmee de bewaker van de ambities en verwachtingen. Ze is te beschouwen als de hoeder van de sacrale vorm. Het programmamanagement is opdrachtnemer van de stuurgroep voor de realisatie van het PAZIOprogramma. Bij het samenstellen van het programmamanagementteam krijgen de verschillende partners in het project ieder hun plek. Daarbij speelt persoonlijk vertrouwen een belangrijke rol. In de programmaopzet worden Torenbeek namens VHS en A. Dekker namens het UMCU opgevoerd als het programmamanagement. De stuurgroep neemt dat als een vanzelfsprekend gegeven over. Dekker en Torenbeek kennen elkaar al jaren. Ze begonnen hun loopbaan beiden als verpleegkundigen bij GGZ Meerkanten en stapten beiden over naar de divisie Hersenen van het UMCU, waar ze zich ontwikkelden als professionals in zorg ICT. In 2006 maakte Torenbeek de overstap naar VitalHealth Software. Hij is daarmee voor VitalHealth Software een vertrouwde programmaleider, zoals Dekker dat is voor het UMCU. Begin 2008 neemt Torenbeek een positie in die meer op de achtergrond is en wordt De Lange vanuit VitaValley naar voren geschoven als projectmanager naast Dekker. De Lange is zelfstandig consultant en voorheen collega geweest van Florijn bij het consultancybureau Ernst \& Young. De aangestelde programmamanagers zijn kortom allen vertrouwelingen van één of meer stuurgroep leden. Zo blijft het netwerk dat zich rond PAZIO vormt een netwerk van mannen die elkaar al jaren kennen, ze vormen een gemeenschap van vertrouwelingen.

Met het ondertekenen van het convenant en de oprichting van de stuurgroep vormt zich een morele gemeenschap. De uitwerking van de

382 De leden van de stuurgroep worden in de programmaopzet als volgt gepresenteerd: 'J. Kuilboer (secretaris Raad van Bestuur UMC Utrecht, directeur concernstaf, voorzitter stuurgroep); R. Florijn (VitaValley); R. van Damme (directeur LRJG); L. van der Tang (CEO VitalHealth Software); H. Nauta, (directeur DIT, UMC Utrecht). Deelnemer vanuit Julius Centrum; Mogelijk deelnemer vanuit Imtech.' Dekker en Hero Torenbeek, Programmaopzet PAZIO. Tekstdocument, 27 november 2007.

383 Witte, Verslag PAZIO-stuurgroepvergadering 26 november 2007. Tekstdocument, 26 november 2007, 1. 
plannen is een eerste product van de samenwerking waarin ambities, uitgangspunten en idealen beschreven worden. Er is daarmee een gedeeld geloof. De morele gemeenschap en het gedeelde geloof versterken elkaar. De sacrale vorm wint daarmee substantieel aan kracht maar is tegelijkertijd nog allerminst robuust. Centraal in deze sacrale vorm staat de nieuwe naam PAZIO, PAtientgeorienteerde ZorgInformatie Omgeving en het bijbehorende logo. Die naam weerspiegelt de idealen: met technologie de patiënt centraal zetten. De naam en het logo zijn de iconen van de sacrale vorm, ze representeren het geloof en de gemeenschap.

Met het gedeeld geloof, het onderling vertrouwen in de gemeenschap en de praktische betrokkenheid zijn daarvoor de eerste fundamenten voor PAZIO gelegd. Daarmee kan PAZIO de wereld in op zoek naar middelen om de plannen in de praktijk te realiseren.

\subsection{PERIODE 2: STEUN VOOR EEN OMNIPOTENT PORTAAL EN DE ICONISCHE PATIËNT}

\subsubsection{VERANDERING 2: EEN MISSIONAIRE GEMEENSCHAP OP ZOEK NAAR MORELE EN MATERIELE STEUN}

Met deze eerste sacrale vorm rond PAZIO ontstaat een basis om een missie op te zetten en deze richting te geven. PAZIO heeft plannen en ambities om te delen, een zichtbaar logo en een bezield verband waar anderen zich bij kunnen aansluiten. Sterker nog: het is noodzakelijk dat anderen zich bij de plannen aansluiten, want anders zijn ze niet te realiseren. Er is geld nodig om de plannen mogelijk te maken, partners om de plannen te realiseren en ambassadeurs om de plannen te promoten en zichtbaar te maken. De komst van VitaValley versnelt het openen van de deuren naar de buitenwereld. Vanuit haar missie zoekt VitaValley naar het algemeen belang en streeft naar samenwerking. Ze erkent de 'noodzaak tot samenwerken (uitgewerkt in de netwerkgedachte) en zij streeft naar een sociaal-maatschappelijk rendement met erkenning van de noodzaak om kostendekkend te opereren.' ${ }^{384}$ VitaValley brengt een inspiratie voor vernieuwing door coöperatie in het project. Vanuit die inspiratie ontstaat een nieuwe open en verkennende fase in de ontwikkeling. De PAZIO-gemeenschap vormt zich mede door de komst van VitaValley tot een missionaire 
gemeenschap, die de wereld in gaat op zoek naar morele en materiele steun. Het ontwikkelen van draagvlak en steun krijgt vorm via twee lijnen, die beide voor een belangrijk deel door VitaValley worden uitgewerkt.

Allereerst werkt VitaValley aan samenwerking tussen de initiatieven voor patiëntenportalen in Nederland om samen voorstellen te doen bij het ministerie van VWS. Parallel daaraan wordt binnen en buiten de zorg naar steunbetuigingen voor PAZIO gezocht om zo draagvlak en subsidie voor het project te verkrijgen.

\section{Patiënten Portaalring}

In haar pogingen om steun te vinden voor PAZIO spreekt VitaValley met vertegenwoordigers van het ministerie van VWS. VWS heeft te kennen gegeven dat PAZIO op zichzelf geen steun zal krijgen. VWS doet wel een informele handreiking. Het ministerie ziet dat het veld van patiëntenportalen erg versnipperd is, waardoor er veel tijd en energie verloren gaat. Een meer gezamenlijk initiatief uit het veld kan mogelijk wel op steun van VWS rekenen. ${ }^{385}$ Dat is voor VitaValley een strategische aanleiding om de banden tussen VitaValley en Nederlandse Patiënten en Consumenten Federatie (NPCF) aan te halen.

De NPCF is een koepelorganisatie voor patiëntenverenigingen in Nederland. Ze werkt op landelijk niveau aan de algemene belangen van patiënten. Ze wordt door vele partijen gezien als het aanspreekpunt en de vertegenwoordiger van het patiëntenperspectief in Nederland. De NPCF werkt aan de ontwikkeling van een eigen gezondheidsportaal Mijn Zorg Online. ${ }^{386}$ In het kader van Mijn Zorg Online werkt de NPCF samen met de regionale patiëntenportaal-initiatieven Zorgportaal Twente (van IZIT in de regio Twente) en Rijnmondnet.nl (regio Rotterdam). Die samenwerking draagt de naam 'Patiënten Portaalring'. VitaValley wil graag gezamenlijk met deze 'Portaalring' optrekken naar VWS. VitaValley en de NPCF schrijven samen een startnotitie met uitgangspunten en nodigen partijen in het veld uit om te komen tot een gezamenlijk initiatief.

Op 10 november 2009 vindt de eerste bijeenkomst van de nieuwe Patiënten Portaalring plaats. Schipaanboord, directeur Beleid en Innovatie bij de NPCF, en Verkerk, voorzitter VitaValley, verzorgen de gezamenlijke aftrap. Naast de hiervoor genoemde partijen is ook een vertegenwoordiger van het ministerie van VWS aanwezig. De Lange wordt op de deelnemerslijst opgevoerd als vertegenwoordiger vanuit VitaValley; formeel is er dus 
geen vertegenwoordiger van PAZIO aanwezig. ${ }^{387}$ Voorafgaand aan de bijeenkomst hebben de deelnemers de startnotitie van de organisatoren NPCF en VitaValley al ontvangen. Die notitie geeft het doel en de ambitie van het overleg weer. Ze opent als volgt:

'Op verschillende plaatsen in Nederland wordt gewerkt aan de ontwikkeling van een patiëntenportaal..... Vanuit de behoefte het wiel niet op verschillende plaatsen opnieuw uit te vinden, is de behoefte ontstaan aan meer samenwerking. De NPCF, IZIT en Rijnmondnet werken al enige tijd samen.... Inmiddels hebben ook een aantal andere partijen (VitaValley, Health Valley, Zorginnovatieforum) aangegeven meer te willen samenwerken. VitaValley en de NPCF hebben daarom het initiatief genomen voor een nadere verkenning van de mogelijkheden om samen met andere partijen een consortium te vormen. Het consortium kan gezamenlijk optreden naar stakeholders als VWS en Nictiz.' ${ }^{388}$

De deelnemers kunnen op die notitie kunnen reageren zodat deze aangescherpt kan worden. De notitie groeit in een tweede bijeenkomst op 18 mei 2010 uit tot een bericht van de Patiënten Portaalring aan het ministerie van VWS. De Patiënten Portaalring positioneert zich met de ambitie om de gebruiker meer regie te geven over zijn zorgprocessen, en interactie en informatie-uitwisseling in de zorg effectief en efficiënt te laten verlopen. Daarbij worden een aantal basisprincipes opgevoerd: Privacy en veiligheid, Patiëntgerichtheid en kwaliteit, Kennisdeling, Standaardisatie. In de notitie worden een aantal concrete vragen aan het ministerie gesteld over zaken als de ontwikkeling van richtlijnen, de perverse effecten van marktwerking om tot een portaal infrastructuur te komen en onderzoek naar de aannames over wat burgers/patiënten en zorgverleners op het gebied van e-Health gaan doen. De stijl van de vragen is die van de Kamervragen aan de minister. VWS wordt niet om hulp gevraagd, maar de vragen hebben de stijl van 'wat denkt de minister te doen aan ... ?' De minister wordt ter verantwoording geroepen. Het verschil met de parlementaire Kamervragen is dat de minister in dit geval niet gehouden is de vragen te beantwoorden. Er volgt een overleg bij het ministerie van VWS, maar een positieve reactie komt er niet uit Den Haag. ${ }^{389}$ Dat bete-

387 'Dat was een bewuste keuze. Zo wilde men voorkomen dat de bijeenkomst bepaald zou worden door het agressieve en machtige PAZIO vanuit het UMCU. Daarbij twijfelde de PAZIO-achterban er niet aan dat De Lange de belangen van PAZIO toch wel zou behartigen.' Persoonlijke communicatie met Verkerk, d.d. 28 april 2015. 
kent ook het einde van de Patiënten Portaalring. Na twee bijeenkomsten valt het doek. De Patiënten Portaalring ontwikkelt zich niet tot een morele gemeenschap.

Hoe kunnen we het uiteenvallen van de Portaalring begrijpen? De portaalinitiatieven die erin participeren hebben veel overeenkomsten. Ze streven een vergelijkbaar doel na: het ontwikkelen van een patiëntenportaal. Ze delen idealen als patiënten-emancipatie en het streven naar betere zorg. Toch lukt het niet om tot een duurzame samenwerking te komen. In de Portaalring-bijeenkomst ontstaan technische discussies over de ideale architectuur en de helderheid van concepten. De focus ligt op het benadrukken van verschillen en niet op het vormen van eenheid. Zo ontstaan er al scheurtjes voordat er een gemeenschap kan ontstaan. ${ }^{390}$ Daarnaast zitten alle projecten in de opstartfase, nog geen van hen heeft een bruikbaar product of prototype. Ze staan allen aan het begin van hun project, hebben net zelf een eigen prille gemeenschap opgebouwd en wat eerste middelen verzameld. Samenwerking kan met het oog op efficiëntie en effectiviteit aantrekkelijk zijn, maar voor de aanwezige initiatieven kan het ook zomaar betekenen dat hun initiatief op moet gaan in een nog onduidelijk grotere geheel. Wat dat betekent voor hun eigen, met veel inzet opgebouwde initiatief, is onduidelijk, net zoals het onduidelijk is wat het voor de status en werkzaamheden van de aanwezige personen zelf betekent. Het is op zo'n moment niet gemakkelijk om over de eigen schaduw heen te springen. In deze onzekere situatie houden de verschillende portaalinitiatieven vast aan wat ze hebben opgebouwd aan profane middelen en aan sacrale idealen.

Dat vasthouden aan wat men heeft opgebouwd wordt ook versterkt doordat er nog geen zicht is op een groter verhaal of een andere sacrale vorm vanuit de Portaalring. De Portaalring biedt concreet geen ander motief dan 'steun van VWS', aangevuld met abstracte algemene ideeën over standaarden en efficiëntie. Bij de Portaalring is weinig te halen, er is geen profaan geld te verdelen, noch is er sacrale inspiratie te vinden.

Ondanks de ambitie en inzet van VitaValley om tot portaalsamenwerking te komen, is PAZIO weinig aangedaan door de mislukking van de Portaalring. De Portaalring was belangrijker voor VitaValley dan voor het PAZIO-consortium. Het initiatief sloot goed aan bij de waarden en overtuigingen van VitaValley op het gebied van samenwerking. Het UMCU-conglomeraat ging veel meer uit van eigen kracht en regie. 


\section{Missie voor moreel en materieel draagvlak}

Naast de inzet voor samenwerking in het Leusderberaad doet PAZIO veel missiewerk in het kader van haar subsidieaanvragen. Er wordt in dat kader een heel lobbyprogramma opgezet, waarin relevant geachte partijen worden geïnventariseerd en gekoppeld aan verschillende PAZIO-lobbyisten. De lobby is niet geheel belangeloos, ze gaat verder dan het verspreiden van het goede nieuws van PAZIO zoals dat in de film gebeurt. Ze is hier expliciet gericht op het borgen van reguliere financiering en het binnenhalen van projectfinanciering. ${ }^{391}$ Er wordt contact gelegd om morele of materiele steun voor PAZIO te krijgen.

Er wordt nu ingezet op het verkrijgen van steun voor PAZIO buiten de eigen organisaties en in het veld. Het gaat daarbij niet langer om het uitbreiden van de stuurgroep of het projectmanagement, want die staan en zijn gevuld. Er wordt gezocht naar partijen die zich laten overtuigen door het geloof in PAZIO en daar deelgenoot van willen worden. Niet door actief in het project te participeren, maar door het project te steunen in woord en daad. Het gaat om bijdragen zonder de wens of mogelijkheid om formele verantwoordelijkheid te dragen of mee te willen besturen. Het PAZIO-consortium probeert strategische relaties te ontwikkelen met verschillende partijen in het zorgveld.

VitaValley krijgt hierin vanuit PAZIO een belangrijke rol toebedeeld. Ze gaat op bezoek bij de partijen in het Haagse politiek-bestuurlijke zorgnetwerk. Ze spreekt onder meer met vertegenwoordigers van het ministerie van $\mathrm{VWS}^{392}, \mathrm{CVZ}^{393}$ en met NICTIZ ${ }^{394}$. Ook spreekt ze met de vereniging van Zorgverzekeraars Nederland en verschillende zorgverzekeraars (Agis, Achmea, Menzis), met beroeps- en koepelverenigingen van zorgprofessionals $\left(\mathrm{NHG}^{395}, \mathrm{KNMG}^{396}\right.$ ) en - zoals eerder beschreven - met een patiëntenorganisatie (NPCF). Zij worden warm gemaakt voor het idee/project PAZIO. ${ }^{397}$

Anders dan bij de Portaalring wordt hier niet gestreefd naar samenwerking, het vormen van een gemeenschap of andere vormen van commitment. De verschillende partijen worden een op een benaderd en geïnformeerd over PAZIO en haar meerwaarde. Er wordt zo gewerkt

391 VitaValley, Lobby PAZIO - doel en opzet. Tekstdocument, oktober 2008.

392 Volksgezondheid, Welzijn en Sport

393 College voor Zorgverzekeringen

394 Nederlands Instituut voor ICT in de Zorg

395 Nederlands Huisartsen Genootschap

396 Koninklijk Nederlands Medisch Genootschap

397 VitaValley, Lobby PAZIO - doel en opzet. Tekstdocument, oktober 2008. 
aan draagvlak. Draagvlak vraagt om een lichte vorm van steun, zonder gemeenschap, gedeelde idealen, verplichtingen of verantwoordelijkheden. Alles blijft vrijblijvend.

Nadat verschillende subsidieaanvragen niet tot een goed einde leiden, wordt eind 2008 ingezet op het verwerven van een subsidie in de regeling Pieken in de Delta. Er is dan ondertussen enige naamsbekendheid en enig draagvlak voor PAZIO gecreëerd. In het kader van de PinDa-subsidieaanvraag wordt een succesvolle missie uitgevoerd om steunbetuigingen voor het project PAZIO te verkrijgen in het veld. Die steunbetuigingen zijn een noodzakelijke voorwaarde voor een succesvolle subsidieaanvraag. PAZIO krijgt elf steunbetuigingen van zorginstellingen (Gezondheidscentrum Maarssenbroek, Stadsmaatschap Huisartsen Utrecht, Diaconessenhuis Utrecht, Amsterdams Medisch Centrum, Zuwe Aveant) verzekeraars (AGIS), bedrijven (PharmaPartners, NIPED) koepels (1elijns Amsterdam, Skill City) en verenigingen (Nederlandse Vereniging voor E-health). De steunbetuigingen bestaan uit een standaardbrief, die op eigen briefpapier ondertekend wordt door de tekenbevoegde vanuit de organisatie. Hoewel men concreet steun betuigt aan PAZIO en daarmee aan haar idealen van het centraal zetten van de patiënt met behulp van technologie, biedt PAZIO de ondertekenaars alle ruimte voor de eigen idealen van betrokkenen. Er worden geen projectplannen, functionele eisen of andere beschrijvingen van PAZIO meegeleverd bij de steunbetuigingen. Daardoor blijft PAZIO een onbeschreven blad waarop ieder zijn eigen idealen kan projecteren. De ruimte voor betekenisflexibiliteit is groot. Het kost daarnaast in praktische zin weinig moeite om steun te betuigen en de steunbetuiging verplicht tot niets. Dat neemt niet weg dat de ondertekenaars met hun handtekening expliciet het PAZIO-initiatief toejuichen.

Het lobby-proces is geïnspireerd door de sacrale vorm van PAZIO met haar streven naar het centraal stellen van de patiënt en het verbeteren van de kwaliteit van zorg door middel van een portaal. Daarvoor gaat men de wereld in, die boodschap wordt verspreid als het goede nieuws. In die zin is dan ook sprake van een gerichte missionaire activiteit. Daarbij is PAZIO in deze fase nog slechts een idee waardoor er ruimte is voor betekenisflexibiliteit. De beoogde steunbetuigers kunnen hun eigen idealen projecteren op PAZIO. De aanwas aan betrokkenen zorgt voor extra steun, maar ook voor een breder palet aan verwachtingen van PAZIO. De combinatie van vrijblijvende betrokkenheid, een heldere sacrale vorm met daarnaast ruimte voor eigen interpretaties en idealen doet deze missie slagen. De steun aan het begrip voor PAZIO verbreedt. 


\subsubsection{STABILISATIE 2: MEVROUW DE WOLF EN PAZIO VORMEN DE SACRALE VORM}

\section{Omnipotent portaal}

Mede dankzij de steunbetuigingen is de Pieken in de Delta-subsidieaanvraag van PAZIO succesvol. Opvallend genoeg, voor een portaal met de ambitie om de patiënt centraal te zetten, is er tussen de steunbetuigingen geen steunbetuiging te vinden van een organisatie die de patiënt vertegenwoordigt. Dat is echter geen onoverkomelijk probleem voor het ministerie van Economische Zaken: ze verleent een subsidie van $€ 2$ miljoen. Het is een enorm succes voor het PAZIO-project en geeft een stevige financiële basis onder het project. Een succesvol project vraagt echter meer dan profane middelen alleen. Hoe behoudt de sacrale vorm van PAZIO haar stabiliteit nu deze vorm nog pril is, haar betekenisflexibiliteit toeneemt en er een verplichting is aangegaan richting de Pieken in de Delta subsidieverstrekker? In deze fase is er allerminst sprake van stabilisering van een technologisch frame. Het tegenovergestelde is het geval: PAZIO is een containerbegrip vol interpretaties en belangen. Daarmee zou het voor de hand liggen dat er een weinig stabiele organisatie zou ontstaan. Toch ontwikkelt de gemeenschap zich op stabiele wijze, doordat met de groei van het aantal groepen en interpretaties ook de sacrale vorm zich ontwikkelt. Dat wordt goed zichtbaar in de kick-off en in de daar vertoonde PAZIO-film, waarin PAZIO overtuigend gepresenteerd wordt als omnipotent portaal. PAZIO gaat ons verlossen van alle ingebrachte problemen en sluit zo aan bij alle interpretaties en relevante sociale groepen. Daarnaast krijgt één relevante sociale groep, die van de patiënten in de persoon van mevrouw De Wolf, een bijzondere status.

\section{Iconische patiënt}

Voor de kick-off was mevrouw De Wolf gewoon een vriendelijke bejaarde dame die in Leidsche Rijn woont. We kennen haar niet, herkennen haar niet op straat. We hebben geen beeld en verhaal bij mevrouw De Wolf. We wisten niet eens dat ze mevrouw De Wolf heette en dat ze klaarblijkelijk vijf jaar in Leidsche Rijn woonde, laat staan dat we iets van haar medische status zouden weten. Op het moment dat tijdens de kick-off de eerste vertoning van de PAZIO-film plaatsvindt, ondergaat mevrouw De Wolf een haast wonderbaarlijke metamorfose: deze onbekende dame wordt plots diegene waarvoor we het allemaal doen. Dat wordt symbolisch bevestigd als het mevrouw De Wolf is die op de rode knop drukt, de confetti de lucht in knalt en ze zo de PAZIOwebsite presenteert. 
We leren mevrouw De Wolf in de film kennen als een vriendelijke zachtaardige dame en in het script worden we meegenomen in haar worsteling met haar chronische aandoeningen. Mevrouw De Wolf klaagt niet, of klaagt in ieder geval heel bescheiden. Zij verlangt slechts naar een beetje vrijheid en verlossing. Dat verlangen is invoelbaar. Het gaat hier om vrijheidsbeperkingen waarvan we in algemene zin wel weten, maar hier een levensecht inkijkje van krijgen. Dat inkijkje maakt dat we mevrouw de Wolf niet snel zullen vergeten. Wellicht vergeet $u$ haar naam of woonplaats maar haar vriendelijke persoon en bescheiden gedragen lijden is iconisch en wekt medelijden op. In de film krijgt het woord 'patient' vlees en bloed in de persoon van mevrouw De Wolf. Dat wordt in de kick-off nog verder geaccentueerd doordat mevrouw De Wolf daar tussen de aanwezigen verschijnt. Ze loopt daar wat onwennig rond. Voordat de film is afgespeeld wordt ze niet herkend, ze zet zich niet in het middelpunt en dringt zich niet op. Ze wordt door de organisatie op het podium gezet, drukt op de rode knop en schrikt van de knallende confetti. Haar verschijning is echt en authentiek. Mevrouw De Wolf verandert van een grote onbekende in een begrip binnen het PAZIO-project. Als het over de patient gaat valt vaak haar naam in het projectteam en de stuurgroep. En haar naam wordt nooit negatief gebruikt, altijd is ze een voorbeeld en inspiratie, nooit is mevrouw De Wolf een probleem. Mevrouw De Wolf maakt van de categorie patiënt een authentiek mens van vlees en bloed. Mevrouw De Wolf wordt een sacraal en inspirerend icoon. Als we het voortaan hebben over de patiënt centraal, denken we allemaal aan mevrouw De Wolf.

Op het moment dat PAZIO een omnipotent portaal wordt, wordt mevrouw De Wolf een icoon voor het project. Ook zíj krijgt een sacrale status. Ze is tegelijkertijd zowel essentieel als onaanraakbaar in het project. Het icoon mevrouw De Wolf en het omnipotente portaal PAZIO trekken samen op, ze vormen een duo als doel en middel, ze maken elkaar mogelijk en vormen daarmee de basis voor de doorontwikkeling van de stabiele sacrale vorm. ${ }^{398}$

\section{De geschiedenis van PAZIO en de patiënt}

Mevrouw De Wolf is lid van het Klantenpanel dat PAZIO in samenwerking met LRJG oprichtte. Het klantenpanel bestaat uit zes patiënten van LRJG, die hier dus klanten genoemd worden. Het streven is om het klantenpanel evenwichtig samen te stellen met betrekking tot leeftijd en gezondheidstoestand. Daarnaast worden Baartmans namens de NPCF en Wanders van Cliëntenbelang Utrecht uitgenodigd voor het panel. 
Het plan van het PAZIO-team is om het panel in drie bijeenkomsten in een half jaar tijd mee te laten denken over de ideeën van PAZIO; een proefversie te tonen en daar reacties op te krijgen; en in de derde bijeenkomst de puntjes op de i te zetten. De bijeenkomsten vinden plaats in de periode van november 2008-februari 2009.

Op 19 november 2008 komt het panel voor het eerst bijeen. In die bijeenkomst wordt feedback gevraagd op de plannen en ideeën rond PAZIO. In de tweede bijeenkomsten wordt het panel gevraagd mee te denken over functionaliteiten, maar is er evenzoveel tijd ingeruimd om van gedachte te wisselen over naamgeving en logo's. ${ }^{399}$ In eerste instantie zijn de bijeenkomsten van het klantenpanel gericht op inhoudelijke uitwisseling. Langzamerhand worden voorlichting, demo's en informatievoorziening vanuit PAZIO belangrijker dan de gedachtewisseling met en feedback van de patiënten. ${ }^{400}$ In een vierde bijeenkomst in juli 2009 staan de stand van zaken en een demo van de tool Diabetes van VHS op het programma. ${ }^{401}$ Voor de daaropvolgende bijeenkomst wordt een bedrijfsbezoek aan VHS geopperd door de organisatie.

Bij de kick-off van het PAZIO-project is vrijwel het complete panel aanwezig. We zagen al dat Mevrouw De Wolf daar met één druk op de knop ongevraagd en onbewust in een heilig icoon verandert. De overige klantenpanelleden blijven anoniem. Ze zijn allen nieuw in deze omgeving en voelen zich wat ongemakkelijk. Gegeven de ambitie de patiënt centraal te stellen, zou het niet vreemd zijn geweest als het klantenpanel op belangstelling had kunnen rekenen van de aanwezigen. Dat is allerminst het geval. De aanwezigen zijn druk met elkaar en geven het klantenpanel weinig ruimte om onderdeel te worden van hun gevestigde netwerken. Met mevrouw De Wolf wordt de patiënt op het podium gezet, maar in de wandelgangen weet men geen raad met de klant. Die is een onbekende en klaarblijkelijk geen vanzelfsprekende partner. Patiënten zijn geen professionals waar je zaken mee kan doen, kaartjes uitwisselen en je netwerk kan ontwikkelen. Hun medische status in plaats van professionele status is leidend maar in een zakelijke omgeving is het niet gebruikelijk en ongemakkelijk om over dergelijke persoonlijke medische zaken te praten. Ook bij de patiënten zien we ongemakkelijkheid. Zij kennen het jargon van dit medisch-technologisch netwerk niet en voor de meeste leden van het panel zijn dit soort business-netwerken nieuw. Er vinden kleine beleefdheidsgesprekjes plaats tussen patiënten en professionals en daarna draaien ze zich snel terug naar hun vertrouwde 
eigen netwerk. Tijdens de kick-off borrel staan het patiënten panel op zichzelf en ontwikkelt zich nauwelijks enige dialoog met de aanwezige professionals.

$\mathrm{Na}$ de kick-off wordt de afstand tussen de professionals en de patienten niet minder. De uitnodiging voor de volgende klantenpanelbijeenkomst wordt diverse malen uitgezet, maar kan bij herhaling niet door gaan door ziekte en afzeggingen van diverse deelnemers. Een laatste poging wordt gedaan in augustus 2010.402 Daarna worden er geen pogingen meer ondernomen om het klantenpanel bijeen te krijgen. Geen van de panelleden heeft daar ook nog naar gevraagd. Ondanks het enthousiaste begin, dooft de vlam van het klantenpanel als een nachtkaars uit.

Dat het klantenpanel geen krachtige rol kan ontplooien in de PAZIOontwikkeling staat niet op zichzelf. De patiënt wordt weliswaar omarmd in de ambities en verhalen van PAZIO, maar in de praktijk wordt hij steeds opnieuw buiten spel gezet. $\mathrm{Al}$ in de eerste stuurgroep vergadering van 26 november 2007 wordt een eventuele rol van de patiëntenvereniging NPCF vriendelijk aan de rand van het project geplaatst, centraal in het project wordt geen ruimte gemaakt. In het verslag is opgenomen dat een goede relatie met de NPCF belangrijk is. 'Het zou goed zijn om hen in een klankbordgroep te betrekken. In een latere fase zou gezamenlijke communicatie naar buiten tot de mogelijkheden behoren. Belangrijk om aansluiting mee te houden. ${ }^{403}$ De samenwerking die VitaValley zoekt met de NPCF rond de Patiënten Portaalring komt niet van de grond en VitaValley blijkt niet in staat om de oorspronkelijke PAZIO-kern van UMCU-partners te overtuigen om de NPCF op te nemen in de kern van het project.

PAZIO heeft de ambitie om de patiënt centraal te stellen in de zorg en is zich ervan bewust dat ze te maken heeft met twee groepen gebruikers: de patiënten en de zorgverleners. Via LRJG zijn de zorgverleners vertegenwoordigd in de stuurgroep. Voor de patiënt is daar geen plek ingeruimd. Het klantenpanel was de meest krachtige formele positie die de patiënt in het project PAZIO kreeg toegewezen. Die formele positie was echter slechts adviserend van aard en niet besluitvormend zoals de stuurgroep of richtinggevend zoals het projectteam.

\section{Sacrale isolatie}

Mevrouw De Wolf is van een grote onbekende getransformeerd tot heilig icoon. Haar zichtbaarheid, aanzien en betekenis is enorm toegenomen, tegelijkertijd is ze - en met haar de patiënten vertegenwoordiging 
- in de praktijk irrelevant en machteloos. Sacraliteit gaat samen met een status aparte, ze wordt verschoond van profane zaken als projectpolitiek en bijbehorende conflicten. Hoe is het te begrijpen dat een sacraal icoon zoals mevrouw De Wolf tegelijkertijd essentieel en machteloos is? Hoe kan het dat iedereen roept dat de patiënt centraal staat, maar zich tegelijkertijd tijdens de kick-off geen raad weet met het klantenpanel? Durkheim gaf al aan dat het sacrale zich niet zozeer hiërarchisch verhoudt tot het profane. Het sacrale is niet vanzelfsprekend ook machtig, het heilige kan juist klein en kwetsbaar zijn. Het sacrale is vooral van een fundamenteel andere orde als het profane.

In lijn daarmee zou de antropologe Mary Douglas zeggen dat de patiënt een anomalie is. Ze past niet in de gevestigde orde. ${ }^{404}$ In de praktijk van een universitair medisch centrum is de patiënt een essentieel onderdeel. $\mathrm{Zij}$ is het object waar alles om draait, waar we het allemaal voor doen. Dat betekent echter niet dat de patiënt ook een rol speelt in de ontwikkeling van het ziekenhuis of de medische expertise. De patiënt ligt in bed, daar is zijn of haar plek in de orde van het ziekenhuis. Het begrip patiënt is nauw verwant aan het Engelse patience. ${ }^{405} \mathrm{Hij}$ of zij wordt geacht geduldig en passief zorg te ontvangen. Als de patiënt uit bed komt en mee gaat praten over vormgeving van zorg, dan treedt zij of hij buiten de orde. De patiënt is dan opeens een vreemde eend in de bijt, een anomalie. Patiënten en professionals weten dat, gedragen zich daarnaar en voelen zich daar meestentijds prettig bij. Tijdens de kick-off wordt de patiënt opeens in een professionele zorginnovatie borrel geplaatst. Dat voelt voor alle aanwezigen ongemakkelijk. Hoe moeten we omgaan met dit in deze context vreemde wezen? Douglas heeft laten zien dat juist mensen, dingen of momenten die buiten de orde vallen een bijzondere status kunnen krijgen. Ze roepen ongemak, verwarring en verwondering op. Men moet nog leren zich ertoe te verhouden en de anomalie een plek en status geven. Die status is vaak dubbelzinnig. Zo ook hier: de patiënt is enerzijds diegene waar alles om draait en wordt daarom heiligverklaard en mevrouw de Wolf wordt een icoon. Anderzijds is de patiënt in deze

404 Douglas, Purity and danger: an analysis of concepts of pollution and taboo., 47-49. 9

405 Patiënt is afgeleid van het Latijnse patientia, dat lijden, dulden, volharding of geduld betekent Muller, Renkema, en Leeman, Wolters' handwoordenboek Latijn-Nederlands. Het is daarmee verwant aan het Engelse patience en patient Simpson, Weiner, en Berg, The compact Oxford English dictionary. 'Ondanks alle streven naar autonomie en zelfregie is het begrip patiënt, meer dan zorgconsument of cliënt dan ook de meest adequate beschrijving van de situatie waarin een ziek of zorgbehoevend iemand zich bevindt'. Boer en Mul, Goede zorg christelijk geïnspireerde ethiek van geval tot geval, 113 
situatie een actor waartoe men zich maar moeilijk en ongemakkelijk kan verhouden. Daarom wordt hij geïsoleerd. Het is deze splendid isolation, die het sacrale onaanraakbaar maakt. De patiënt wordt in een sacraal isolement achtergelaten.

In deze fase van de ontwikkeling van PAZIO vindt de co-creatie plaats van PAZIO als verlosser en Mevrouw de Wolf als de te verlossen persoon. Zij bepalen elkaar en geven elkaar vorm en betekenis, daarbij krijgen ze beide een sacrale status. Mevrouw de Wolf wordt in de PAZIO-context de iconische patiënt. PAZIO wordt een verlossend omnipotent portaal. Dat geeft stabiliteit aan de sacrale vorm. De PAZIO-gemeenschap, met al haar verschillende relevante sociale groepen en hun interpretaties van PAZIO verzamelt zich rond het omnipotentie portaal PAZIO en sacrale patiënt die zichtbaar wordt in de iconische mevrouw De Wolf. De sacrale vorm geeft stabiliteit aan het geloof en de gemeenschap.

\subsection{PERIODE 3: HET PORTAAL IN DE PRAKTIJK}

\subsubsection{VERANDERING 3: PROFANE STRIJD OVER SACRALE ZAKEN IN DE PRAKTIJK}

Als er met het omnipotente portaal en de iconische patiënt een sacrale vorm ontstaat, is de uitdaging voor de PAZIO-gemeenschap om de gedane beloften te realiseren. De tijd is aangebroken om een PAZIOpilot implementatie te realiseren in de praktijk van eerstelijnsorganisatie en PAZIO-partner LRJG.

LRJG is partner in het PAZIO-consortium, levert een stuurgroeplid en ondertekent het bijbehorende convenant. LRJG is vanaf het prille begin van PAZIO een relevante sociale groep. In de praktijk brengt LRJG naast bestuurders ook zorgverleners in als relevante sociale groep. Waar het tot voor deze periode over de abstractie PAZIO ging, betreedt PAZIO nu de praktijk van het LRJG met de intentie een concrete rol te spelen in haar primaire zorgprocessen. Ze raakt daarmee aan de behandelrelatie tussen zorgverlener en patiënt. Daardoor veranderen de verhoudingen: in de LRJG-praktijk is LRJG uiteraard leidend en niet PAZIO en in de LRJG-praktijk spelen niet alleen de LRJG-bestuurders een rol, maar zeker ook het zorg verlenend personeel. Met de zorgverleners verschijnt er in deze periode een nieuwe relevante sociale groep op het toneel.

Met de bestuurders van het LRJG is in 2007 al afgesproken dat de huisartsen, assistenten en de praktijkondersteuners met PAZIO gaan werken en dat er tijdens de pilot minstens vijfhonderd LRJG-patiënten zullen worden geïncludeerd in PAZIO. Dat wil zeggen dat minstens 
vijfhonderd patiënten zich aanmelden voor PAZIO.406 De zorgverleners zijn echter niet meegenomen in die afspraken en de ontwikkeling van PAZIO. ${ }^{407}$ Als PAZIO bij LRJG geïmplementeerd wordt, is ze voor de zorgverleners dan ook vrijwel onbekend. Het bleek hiervoor al dat de patiënt als beoogde gebruiker van PAZIO nauwelijks een rol heeft gekregen in de ontwikkeling van PAZIO, en hetzelfde blijkt nu dus ook voor de zorgverleners. Het missiewerk van PAZIO heeft zich gericht op bestuurders en ambassadeurs, niet op de beoogde gebruikers. De positie van de zorgverleners is echter zeer verschillend van die van de patiënt. De patiënt is heilig, maar praktisch machteloos. De zorgverleners in het PAZIO-project worden allerminst als sacraal gezien. In de samenwerking wordt op hen afgegeven en wordt zakelijk het gevecht met ze aangegaan. Ze worden daarbij niet ontzien en daarmee zeker serieus genomen. De zorgverleners krijgen geen sacrale status, maar zijn in de praktijk wel degelijk machtig. Hun directeur zit in de stuurgroep. Daarnaast zijn het de zorgverleners die PAZIO moeten gaan gebruiken ${ }^{408}$ en introduceren richting de patiënt. Dat geeft ze een aantal sterke troeven in handen in de ontwikkeling van PAZIO. De PAZIO-ontwikkeling is in deze fase sterk afhankelijk van de zorgverleners, ze kan niet om hen heen.

Al snel na de start van de pilot begin 2010 blijkt dat de zorgverleners niet overtuigd zijn van de meerwaarde van PAZIO en dat ze niet van plan zijn om PAZIO in zijn huidige vorm te gebruiken. De pilot stevent direct bij haar start in een razend tempo op een crisis af. Voor de zorgverleners is de behandelrelatie een essentieel onderdeel van de sacrale vorm. Dat sluit echter niet zondermeer aan op sacrale vorm van het PAZIO-team. Daardoor is er geen gedeelde sacrale grond als vanzelfsprekend en gezamenlijk vertrekpunt. Het maakt de communicatie over en werken aan het sacrale moeizaam en de zorgverleners uiten zich daarom in profane termen: PAZIO levert volgens de zorgverleners extra werk op in plaats van dat ze meerwaarde heeft voor de zorgverlener. Het effect is dat PAZIO niet tot nauwelijks wordt gebruikt, want zo stellen de zorgverleners: met PAZIO valt niet te werken. De zorgverleners geloven niet in de meerwaarde van PAZIO in zijn huidige vorm voor hun praktijk. Tegelijkertijd ligt het succes van PAZIO wel in hun handen.

Het PAZIO-team is op haar beurt zeer verbolgen dat er bij LRJG, na alle eerdere vertragingen, nu opnieuw geen stappen gezet worden. Halverwege 2010 zijn het aantal geïncludeerde patiënten en het 
aantal eConsulten op één hand te tellen. Terwijl de afspraak was dat er vijfhonderd patiënten geïncludeerd zouden zijn. In de beleving van het PAZIO-team zit LRJG in de weerstand. Daarmee ontstaat in en om de stuurgroep onenigheid tussen LRJG en PAZIO over de implementatiepilot. Het is in deze fase niet het gedeelde geloof dat de partners bij elkaar houdt. Inhoudelijk zijn PAZIO en LRJG het geruime tijd oneens.

De draagkracht van het implementatietraject ligt in deze fase niet in het geloof maar op een andere manifestatie van de sacrale vorm: op de gemeenschap die men samen heeft opgebouwd en waar ze beide onderdeel van zijn. Hier draait het om het bij elkaar horen, het geloof, vertrouwen en commitment naar elkaar houdt de partijen bij elkaar. PAZIO en LRJG zijn beide initiatieven van het UMCU en het UMCU verbindt hen. Die verbondenheid wordt verpersoonlijkt door Kuilboer als voorzitter van de PAZIO-stuurgroep en tevens voorzitter van de Raad van Toezicht van het LRJG. PAZIO en LRJG hebben een gedeelde geschiedenis opgebouwd en delen een project. Dat zorgt voor trouw aan elkaar ook als het vertrouwen in het project even minder is.

Ondanks alle inhoudelijke spanningen willen de spelers het project nog steeds samen verder brengen. Dat betekent niet dat de relaties en het geloof stabiel zijn, juist in deze fase staat er veel op losse schroeven. De aard van de relaties tussen LRJG en PAZIO verandert formeel gezien niet, maar in de praktijk ontwikkelt het partnerschap tussen LRJG en PAZIO zich tot een klant-leveranciers relatie. LRJG is de klant die eisen stelt aan zijn leverancier PAZIO. Als het gedeelde geloof uit het zicht raakt, heeft dat gevolgen voor de relatie: LRJG ziet de problemen als een technische zaak van de 'leverancier' in plaats van een gezamenlijke uitdaging. ${ }^{409}$ De sacrale vorm die nog inspireerde voor de implementatie van PAZIO bij LRJG verliest nu aan eenheid en kracht.

Opnieuw gaat de PAZIO-gemeenschap op zoek naar partners, nu niet voor geld of draagvlak, maar om profane problemen rond de HISintegratie op te lossen. Daarvoor zijn niet zozeer partners nodig die geloven in PAZIO, er zijn partijen nodig die voor technische oplossingen kunnen zorgen. De hulp wordt ingeroepen van twee nieuwe relevante sociale groepen: PharmaPartners en Pharmeon die elk op eigen wijze de HIS-integratie zouden moeten kunnen realiseren.

PharmaPartners is een grote speler op de HIS-markt in Nederland. Ze bedient in 2010 meer dan de helft van de huisartsen met Medicom en heeft daarnaast met Pharmacom ook een aanzienlijk marktaandeel van de apothekersinformatiesystemen in Nederland. PharmaPartners 
heeft daarnaast vanaf 2008 flink geïnvesteerd in de ontwikkeling van haar eigen patiëntenportaal Mijngezondheid.net (MGn). ${ }^{410}$ Dat portaal is volledig geïntegreerd met het HIS Medicom en Apothekers Informatie Systeem (AIS) Pharmacom. Anders dan PAZIO is MGn alleen bruikbaar in combinatie met PharmaPartners-producten en ook alleen beschikbaar voor haar HIS- en AIS-cliënten. Het HIS is de digitale ruggengraat voor een gezondheidscentrum. Het is voor zorgverleners dan ook geen eenvoudige, om niet te zeggen ingrijpende, stap om van HIS te wisselen. In combinatie met MGn wordt die lock-in nog sterker. Het veranderen van HIS betekent dan dat ook de patiënten van het gezondheidscentrum een nieuw systeem als gezondheidsportaal voorgeschoteld krijgen. In 2010 is MGn echter nog geen groot succes. Het aantal gebruikers en het gebruik blijft zowel wat zorgverleners als patiënten betreft achter ten opzichte van de gedane investering en kosten. Integratie met PAZIO is in die situatie niet vanzelfsprekend. Daarmee versterkt PharmaPartners de concurrentiepositie van PAZIO, die in ieder geval op het terrein van portalen ook een concurrent is. Tegelijkertijd kan samenwerking met PAZIO voor PharmaPartners strategische voordelen hebben. PharmaPartners wil dan ook zeker praten over integratie, maar heeft die integratie niet vanzelfsprekend hoog op haar prioriteitenlijstje staan.

PAZIO is lange tijd in gesprek met PharmaPartners over integratie. Die gesprekken begonnen al eind 2009 rond de tijd dat PAZIO net de toezegging van de PinDa subsidie had gekregen. De gesprekken zijn in die fase nog zeer verkennend. De gesprekspartners zijn geen onbekenden voor elkaar. Knoop is de gesprekspartner vanuit PharmaPartners, maar was eerder adviseur e-health bij het UMCU en stond zo met de andere initiators aan de wieg van het PVZ en PAZIO. Hij kent het UMCU, Mediportaal en PAZIO van binnenuit en gaat in gesprek met A. Dekker met wie hij eerder samenwerkte. Begin 2010 presenteren zij een initiële versie van een 'Gezamenlijke visie PatiëntenPortaal PharmaPartners PAZIO'411 aan de bestuurders Kuilboer (PAZIO) en Nederhof (directeur PharmaPartners). Het document omvat 20 pagina's en bevat de visies van PharmaPartners en PAZIO met betrekking tot de rol en inzet van een patiëntenportaal binnen de gezondheidszorg in Nederland. Het gedeeld geloof van beide partijen is:

'door de patiënt een meer prominente plek te geven in de zorg zal ook hij/zij moeten beschikken over een eigen toepassing die in het groter geheel mee kan doen. De patiënt zal met een eigen 
PHIS ${ }^{412} /$ portaal toegang krijgen tot zijn/haar dossier en met deze toepassing kunnen communiceren met de andere zorgverleners.' ${ }^{413}$

Op basis van de gezamenlijke visie wordt besloten een samenwerkingsovereenkomst op te stellen, die op 29 maart 2010 getekend wordt door Kuilboer en Nederhof. Daarmee bekrachtigen zij 'de gezamenlijke intentie tot een niet-exclusieve strategische alliantie'.414 De samenwerkingsovereenkomst is algemeen en conceptueel van aard. Er worden geen concrete doelen, noch concrete middelen, bijdragen of taken beschreven. Wat de samenwerkingsovereenkomst waard is, zal in de praktijk moeten blijken. Komen PAZIO en PharmaPartners dan tot integratie van PAZIO met Medicom? Voor PAZIO wordt dat van groot belang als LRJG dit als voorwaarde stelt om PAZIO te implementeren. De kosten die PharmaPartners voor de integratie rekent zijn hoog, er zijn fundamentele beveiligingsissues en de realisatie vraagt veel tijd. De conclusie van het PAZIO-team is dat Medicom-PAZIO-integratie er voorlopig niet gaat komen.

Om de profane praktische problemen op te lossen wordt een nieuwe partner gezocht en een nieuw scenario ontwikkeld. LRJG besluit in januari 2011 een traject in te gaan waarin voorlopig geen HIS-integratie plaatsvindt. ${ }^{415}$ Er wordt met PAZIO afgesproken dat er een alternatief scenario ontwikkeld wordt, waarbij LRJG bereid is om met een workaround te werken tot 31 december $2011 .{ }^{416}$ Er moet op korte termijn een workaround gevonden worden waardoor de patiënten PAZIO kunnen gebruiken en de zorgverleners van LRJG desondanks niet in twee systemen moeten werken. Daarmee komt er nog een andere speler op het podium: Pharmeon, een grote leverancier van online tools en websites voor huisartsen. ${ }^{417}$ PAZIO biedt voor Pharmeon in principe een platform om haar tools en websites verder te vermarkten. Zo heeft Pharmeon tools voor eConsult, eRecept en eAfspraak in haar pakket. Het idee is dat Pharmeon een workaround voor de integratie gaat realiseren door een zogenaamd EDIFACT bericht van een eConsult of eRecept bericht naar het HIS te sturen. EDIFACT berichten zijn gestandaardiseerde berichten, die als zodanig automatisch als bijlage

412 PHIS staat voor Personal Health Information System

413 PAZIO en PharmaPartners, Gezamelijke visie patiëntenportalen. Tekstdocument, 1 februari 2010, 16.

414 PAZIO en PharmaPartners, Samenwerkingsovereenkomst PAZIO - PharmaPartners. Tekstdocument, 26 april $2010,3$.

415 Well, PAZIO-Logboek januari 2011. Tekstdocument, januari 2011.

416 Well, Aanvulling bij revitaliseringsplan PAZIO@LRJG. Tekstdocument, 3 maart 2011.

417 Pharmeon, 'Pharmeon'. 
in het HIS kunnen worden weg geschreven. Daarmee wordt voorkomen dat de zorgverlener in twee systemen moet werken en ieder eConsult of eRecept uit PAZIO moet knippen en in het HIS moet plakken. Pharmeon is op dat moment al leverancier van de LRJG-website en dus een bekende samenwerkingspartner. Voor Pharmeon is het van belang de relatie met haar klant LRJG goed te houden en om betrokken te zijn bij het potentieel succesvolle platform PAZIO. Tegelijkertijd moet Pharmeon wel aan haar financiële positie denken. Zij heeft niet vanzelfsprekend de financiële middelen en personele capaciteit om in PAZIO te investeren. De praktische samenwerking komt dan ook moeizaam van de grond. Er worden plannen gemaakt en ambities uitgesproken maar in de praktijk gebeurd er weinig. Dat veranderd als er een stevig maar goed gesprek plaats vindt tussen Kreyts (directeur Pharmeon) en het PAZIOprojectteam. Er worden financiële afspraken gemaakt en Pharmeon gaat in een versnelling aan de gang. Net als PharmaPartners heeft Pharmeon pragmatische, strategische redenen om aan te sluiten. Niet de gedeelde visie op zorg of zorginnovatie is leidend, maar veel meer is er sprake van een zakelijk en strategisch partnerschap.

PharmaPartners en Pharmeon brengen als nieuwe relevante sociale groepen ook nieuwe interpretaties van PAZIO met zich mee. Zowel Pharmeon en PharmaPartners zien PAZIO als een vehikel om hun eigen producten in de markt te kunnen zetten. Dat is goed te begrijpen vanuit hun identiteit. Pharmeon en PharmaPartners zijn commerciële partijen die economisch gedreven worden, vanuit die houding wordt PAZIO begrepen. Zij worden dan ook niet als partners in het PAZIO-project gevraagd, maar ze worden gevraagd als leverancier en ontwikkelaar van oplossingen voor het HIS-integratie probleem. Uiteraard geloven zij in zorginnovatie en de meerwaarde van ICT in de zorg, daar is hun bedrijfsmodel op gebaseerd. Het is de basis voor hun primair commerciële identiteit. Dat zij zich verbinden aan het streven naar zorginnovatie moeten we vanuit die identiteit begrijpen. Ze verbinden zich niet aan de sacrale vorm PAZIO, maar zijn leverancier voor het project PAZIO en gaan daarom niet zozeer een ideële als wel een commerciële en strategische relatie aan met PAZIO. Door hun afstand als leveranciers tot de kern van de PAZIO-gemeenschap, heeft hun interpretatie beperkte invloed op de sacrale vorm PAZIO. Tegelijkertijd spelen ze een belangrijke rol in de praktische ontwikkeling van PAZIO en geven ze daaraan mede vorm. PharmaPartners en Pharmeon zijn weliswaar geen participerende partners in het PAZIO-project, als leveranciers leveren ze wel verschillende producten en daarmee scenario's voor de PAZIO-pilot bij LRJG. Daarmee ontstaan nieuwe keuzes en een nieuwe betekenisflexibiliteit en ruimte voor innovatie. 
Naast de nieuwe ruimte voor innovatie heeft alle aandacht voor de HIS-integratie op een praktische manier een aanzienlijke invloed op de ontwikkeling van PAZIO. Het onderhandelen met zorgverleners, PharmaPartners en Pharmeon over de HIS-integratie vraagt onverwacht veel tijd en geld van het PAZIO-team. Die tijd en dat geld kunnen niet aan andere zaken kunnen besteed worden. De zorgverleners en leveranciers hebben zo indirect een groot effect op de ontwikkeling van PAZIO. Zij dwingen af dat er aan profane zaken gewerkt wordt om het sacrale mogelijk te maken maar leiden daar tegelijkertijd vanaf. In deze fase staat de patiënt allerminst centraal in de ontwikkeling.

\subsubsection{STABILISATIE 3: RITUELEN VOOR DE DIGITALE BEHANDELRELATIE}

Hoe ontstaat er met de nieuwe relevante sociale groepen en interpretaties van PAZIO bij LRJG een stabiele praktijk? Zoals we in hoofdstuk vier zagen, ontvouwen zich twee scenario's voor de implementatie van PAZIO bij LRJG: HIS-integratie met Mijngezondheid.net naast PAZIO op de LRJG-website, waardoor er aparte inlogknoppen voor PAZIO en Mijngezondheid.net voor patiënten op de site verschijnen. Het maakt het werk voor de LRJG-zorgverleners weliswaar eenvoudiger, maar creëert ook een onduidelijke en veranderlijke digitale behandelrelatie voor de patiënten. Het andere scenario is het Portaal-integratie scenario waarin de patiënt één inlogknop krijgt waarachter hij alle digitale zorgservices vindt. Dat faciliteert de digitale behandelrelatie tussen patiënt en zorgverlener optimaal maar gaat wel ten koste van de HIS-integratie en levert dus een aanzienlijke hoeveelheid extra werk op voor de zorgverleners. Dat is voor LRJG een serieus maar profaan probleem. Het benodigde extra werk raakt niet aan het primaire zorgproces en de sacrale behandelrelatie. Doordat de HIS-integratie een profane wens was, kon LRJG er eenvoudig overheen stappen toen die niet gerealiseerd werd. Als LRJG voor de keuze tussen HIS- of Portaal-integratie staat, wordt zonder meer gekozen voor Portaal-integratie. Ze kiest voor versterking van de sacrale digitale behandelrelatie en accepteert dat ten koste van profaan werk.

De overtuigende keus voor Portaal-integratie bevestigt de sacrale vorm van LRJG en ze geeft helder richting aan de realisatie van de implementatie van PAZIO bij LRJG. Tegelijkertijd moet die realisatie nog wel plaatsvinden en is ze van essentieel belang om tot een stabiele praktijk met een digitale behandelrelatie te komen. De beoogde sacrale vorm vraagt in de praktijk om rituelen voor authenticatie van patiënt en zorgverleners, triage, agendabeheer. Profane zaken als tijd, ruimte, mensen, protocollen en materialen moeten worden afgestemd op het sacrale om rituelen te ontwikkelen die recht doen aan de sacrale vorm voor de digitale behandelrelatie. Met de ontwikkeling van de rituelen voor de digitale 
behandelrelatie ontstaat een stabiele digitale zorgpraktijk en een in de praktijk werkende sacrale vorm waarin geloof, gemeenschap en rituelen het sacrale vormgeven en bekrachtigen.

\subsection{MEER VERANDERING EN STABILISATIE}

De verdere ontwikkeling van de PAZIO valt formeel buiten de kaders van dit proefschrift, maar een snelle blik laat zien dat daar steeds opnieuw periodes met fases van verandering en stabilisatie in te herkennen zijn. Nadat PAZIO in de LRJG-praktijk is geïmplementeerd en aan de LRJG-voorwaarde voor de digitale behandelrelatie is voldaan, is het zaak om ook patiënten te overtuigen van het belang en de meerwaarde daarvan. Om PAZIO succesvol te maken moeten de patiënten PAZIO gaan gebruiken, alleen dan kan een digitale behandelrelatie tot stand komen, $\mathrm{Na}$ de zorgverleners moeten ook de patiënten als gebruikers onderdeel worden van de PAZIO-gemeenschap. De ontwikkeling van het gebruik van PAZIO in de behandelrelatie is niet vanzelfsprekend. De uitdaging is om patiënten te informeren over PAZIO, hen te introduceren in het gebruik van PAZIO en hen te verleiden om PAZIO te gebruiken in de praktijk van hun dagelijks leven. Dat vraagt extra inzet en investeringen vanuit PAZIO en LRJG. Vanuit PAZIO worden PAZIO-promotieteams opgezet. Die promotieteams bestaan uit studenten die met een tablet de wachtkamers van LRJG in gaan om patiënten te informeren over de mogelijkheden van PAZIO en hen introduceren in het werken met PAZIO. ${ }^{418}$ PAZIO en LRJG hopen op die manier patiënten te overtuigen van de meerwaarde van PAZIO, ze vertrouwd te maken met de rituelen van het gebruik van PAZIO en hen aan te sluiten bij de PAZIO-gemeenschap.

Daarnaast ligt er nog een andere uitdaging voor PAZIO. Anders dan MGn belooft PAZIO de patiënt integratie van verschillende digitale zorgapplicaties en digitale toegang tot verschillende zorgverlenersprakijken. Hiervoor moeten ziekenhuizen, specialisten, paramedici PAZIO implementeren en aanbieden aan hun patiënten. Dat betekent dat er meer nieuwe relevante groepen zich moeten verhouden tot PAZIO, groepen die hun eigen sacrale vormen meebrengen. Ook deze sacrale vormen moeten worden afgestemd op PAZIO. PAZIO blijft daardoor in ontwikkeling. In 2020 zien we op de website van PAZIO een nieuwe beschrijving van wat PAZIO aanbiedt: 
'PAZIO is een overkoepelend platform waarin online diensten van zorg- en welzijnsorganisaties worden samengevoegd in een helder en toegankelijk platform voor inwoners van Nederland. Toegang tot alle zorg-\& welzijnsdiensten met één veilige inlog. Waarbij patiënt en cliënt door inzicht in zijn gegevens, in alle leeftijdsfasen, een centrale rol heeft in de regie en het zelfmanagement van zijn gezondheids- en welzijnssituatie.' ${ }^{419}$

Veel van wat we in de eerste PAZIO-film zagen, zien we hier terug. Er zijn accenten verschoven, maar de kern lijkt overeind gebleven: PAZIO biedt de patiënt en cliënt inzicht, regie en zelfmanagement rond zorg en nu ook welzijn. Op de site beschrijft PAZIO haar aanbod aan zorgverleners, aan patiënten, aan cliënten van die zorgverleners en nu ook aan gemeenten en welzijnsorganisaties. Het huidige aanbod wordt verbeeld en verwoord in een nieuwe PAZIO-film die afsluit met:

'Het resultaat:

Inwoners die meer regie hebben over hun eigen gezondheid; Betere kwaliteit van zorg en welzijn; Tijdwinst voor de zorg- of welzijnsverlener; Minder kosten door efficiënte werkwijze; En tenslotte voldoet de zorg of welzijnsverlener aan de actuele regelgeving

PAZIO de oplossing om e-healthdiensten te integreren.' ${ }^{420}$

PAZIO wordt ook in deze film gepresenteerd als een omnipotent portaal dat de oplossing biedt om te integreren. Dat integreren blijkt steeds opnieuw niet met een klik van de muis te realiseren. Het vraagt om inspiratie voor innovatie: het is veel werk om geloof, rituelen en gemeenschap te integreren en een waardevolle stabiele praktijk te ontwikkelen.

\subsection{CONCLUSIES}

In de drie onderzochte periodes in de PAZIO-ontwikkeling wordt steeds een vergelijkbare dynamiek zichtbaar: op een fase van verandering volgt een fase van verbinding. Daarin ontwikkelen relevante sociale groepen zich tot morele gemeenschapsvorming die op hun beurt op zoek gaan naar nieuwe relevante sociale groepen om problemen op te 
lossen en idealen te verwezenlijken. De sacrale vorm zorgt daarbij in elke fase voor richting. Ze is een inspiratie voor innovatie waarmee ze verandering in gang zet en een verbindende kracht die zorgt voor de eenheid en stabiliteit in een praktijk.

\subsubsection{DE DYNAMIEK VAN DE VERANDERFASE}

Vanuit een stabiele praktijk met een heldere sacrale vorm ontstaan perspectieven op verbetering voor de diezelfde praktijk. Dat kan bijvoorbeeld het leveren van zorg zijn zoals dat bij LRJG plaatsvindt of het ontwikkelen van technologie zoals dat bij PAZIO gebeurt. De sacrale vorm levert de betreffende gemeenschap inspiratie voor innovatie. Daardoor stellen de gemeenschap en de praktijk zich open voor vernieuwing en ontstaat ruimte voor nieuwe spelers. Die spelers werken en leven vanuit een eigen sacrale vorm en brengen daarmee eigen geloofselementen en rituelen met zich mee. Er ontwikkelt zich een sacrale diversiteit en daarmee een betekenisflexibiliteit van het artefact of project waar de spelers zich omheen verzamelen.

De sacrale vorm is fundamenteel voor een groep of gemeenschap, hij bepaalt hoe tegen een situatie aangekeken wordt, hoe die begrepen moet worden en wat men te doen staat. Zolang er geen gedeelde sacrale vorm is, is er geen gemeenschap, maar een verzameling relevante sociale groepen met ieder een eigen idee van een artefact of project. Er is geen gemeenschappelijke richting, noch gemeenschappelijke basis om aan het project of artefact te werken. In navolging van de wetenschapshistoricus Kuhn kunnen we spreken van een crisis. Anders dan bij Kuhn gaat het hierbij niet om een crisis in een wetenschappelijk paradigma, maar om een sacrale crisis in de ontwikkeling van een socio-technische praktijk. De verschillende relevante sociale groepen zorgen voor een sacrale diversiteit, waardoor de vanzelfsprekendheid van de richting waarin en manier waarop het project of artefact ontwikkeld moet worden verdwijnt. Het onderling vertrouwen komt onder druk te staan en is er onvoldoende gemeenschappelijk taal of traditie. In een dergelijke crisis wordt in de strijd of samenwerking vaak teruggevallen op profane zaken en overwegingen. Niet het gedeelde ideaal, de gezamenlijke ambities en het onderling vertrouwen, maar de particuliere belangen, machtsverhoudingen en financiële zaken dringen zich op de voorgrond in de interactie om de eigen ongedeelde sacrale ideeën en idealen te verwezenlijken. Het is daarbij zaak om op basis van de verschillende belangen en inspiraties voor innovatie een sacrale gemene deler te ontwikkelen.

Samenvattend: in de veranderfase speelt het sacrale een belangrijke rol. Het geeft inspiratie voor innovatie en daarmee creatieve ruimte voor 
nieuwe spelers: er ontstaat sacrale diversiteit. Om een project of artefact succesvol te ontwikkelen is het van belang om vanuit die sacrale diversiteit en betekenisflexibiliteit een nieuwe sacrale vorm te construeren.

\subsubsection{DE DYNAMIEK VAN DE STABILISATIEFASE}

Vanuit de sacrale diversiteit die ontstaat in de veranderfase wordt steeds weer een gedeelde sacrale vorm geconstrueerd, die op haar beurt inspireert tot innovatie en nieuwe ontwikkelingen.

In de eerste periode van de PAZIO-ontwikkeling wordt vertrokken vanuit de particuliere perspectieven en belangen van de betrokken partijen. Vervolgens ontwikkelde zich een gedeeld geloof: in de plannen worden de gedeelde ambities en idealen geformuleerd, in de projectorganisatie krijgt iedereen een rol. Daarmee ontstaat vertrouwen in elkaar en in het project. Dat wordt bekrachtigd in een convenant en formele projectstukken.

In de tweede periode worden nieuwe partners gezocht die PAZIO moreel en materieel willen steunen. Daartoe wordt een narratief rond PAZIO geconstrueerd waarin een problemen in de zorg gekoppeld worden aan een oplossing: PAZIO. Met het partnernetwerk ontwikkelt zich een breed gedragen geloof in de iconische patiënt mevrouw De Wolf die verlangt naar een beetje vrijheid en het omnipotente portaal PAZIO, dat de problemen van mevrouw De Wolf en vele andere problemen in de zorg kan oplossen.

In de derde periode wordt gezocht naar een nieuw narratief, waarin de sacrale overtuigingen van 'de patiënt centraal' voor PAZIO en de behandelrelatie voor LRJG kunnen samengaan. Door het ontwikkelen van een digitale behandelrelatie wordt gewerkt aan service aan de patiënt en ontstaat een gedeeld ideaal. De uitwerking daarvan in rituelen zorgt ervoor dat de gedeelde sacrale vorm daadwerkelijk vorm krijgt en het vertrouwen in elkaar en geloof in het project groeit.

In PAZIO ontstaan in de verschillende ontwikkelperioden steeds meer of minder stabiele sacrale vormen op basis van combinaties van een gedeeld geloof, gezamenlijke rituelen en een morele gemeenschap geconstrueerd. Zo'n stabiele sacrale vorm biedt op haar beurt zicht op problemen en geeft richting aan nieuwe inspiratie voor innovatie en luidt zo een volgende veranderfase in.

\subsubsection{DE MEERWAARDE VAN DE SACRALE VORM}

Hierboven is de dynamiek in de ontwikkeling van de PAZIO-probe geanalyseerd en beschreven vanuit het concept sacrale vorm. De meerwaarde daarvan is tweeledig: allereerst geeft het concept sacrale vorm ruimte om zaken als overtuigingen, idealen en 
verwachtingen een plek te geven in de analyse van socio-technische verandering. Als tweede kan met het concept sacrale vorm zowel sociotechnische verandering als stabiliteit begrepen worden.

Met het gebruik van het concept sacrale vorm wordt actief ruimte gemaakt voor de rol van vooronderstellingen, idealen en verwachtingen naast allerlei vormen van theoretische, praktische of ervaringskennis. Die inhoudelijke geloofsoverwegingen worden herleid tot het onderscheid tussen sacrale en profane. Dat geeft structuur. Technologische of wetenschappelijke ontwikkelingen worden daardoor niet slechts begrepen in termen van kennis en sociale verhoudingen. Zij zijn het resultaat van meer dan rationele vooruitgang of een contingent machtsspel, met het sacrale wordt een andere orde naast de profane orde aangebracht. Er staat naast alle kennis- en machtsverhoudingen ook een andere orde op het spel, die door de relevante sociale groepen als absoluut wordt beschouwd en niet gereduceerd kan worden tot diezelfde kennis of macht. Het sacrale kan paradoxaal genoeg machteloos zijn en desondanks van groot belang in de ontwikkeling, de iconische mevrouw de Wolf is daarvan een illustratie. Het sacrale geeft richting aan de ontwikkeling in de vorm van inspiratie voor innovatie en integratie van narratieven, activiteiten en sociale verbanden in een praktijk.

Het concept sacrale vorm is geschikt voor het beschrijven van zowel verandering als stabiliteit van een praktijk. Vanuit een eigen sacrale vorm neemt een relevante sociale groep of gemeenschap eigen rituelen en inspiratie voor innovatie mee in een veranderproces. Om de innovatie te laten slagen is het noodzakelijk dat vanuit de verschillende rituelen en inspiraties van de relevante sociale groepen een nieuwe sacrale vorm ontstaat en daarmee een nieuwe gemeenschap met eigen geloof en rituelen. 



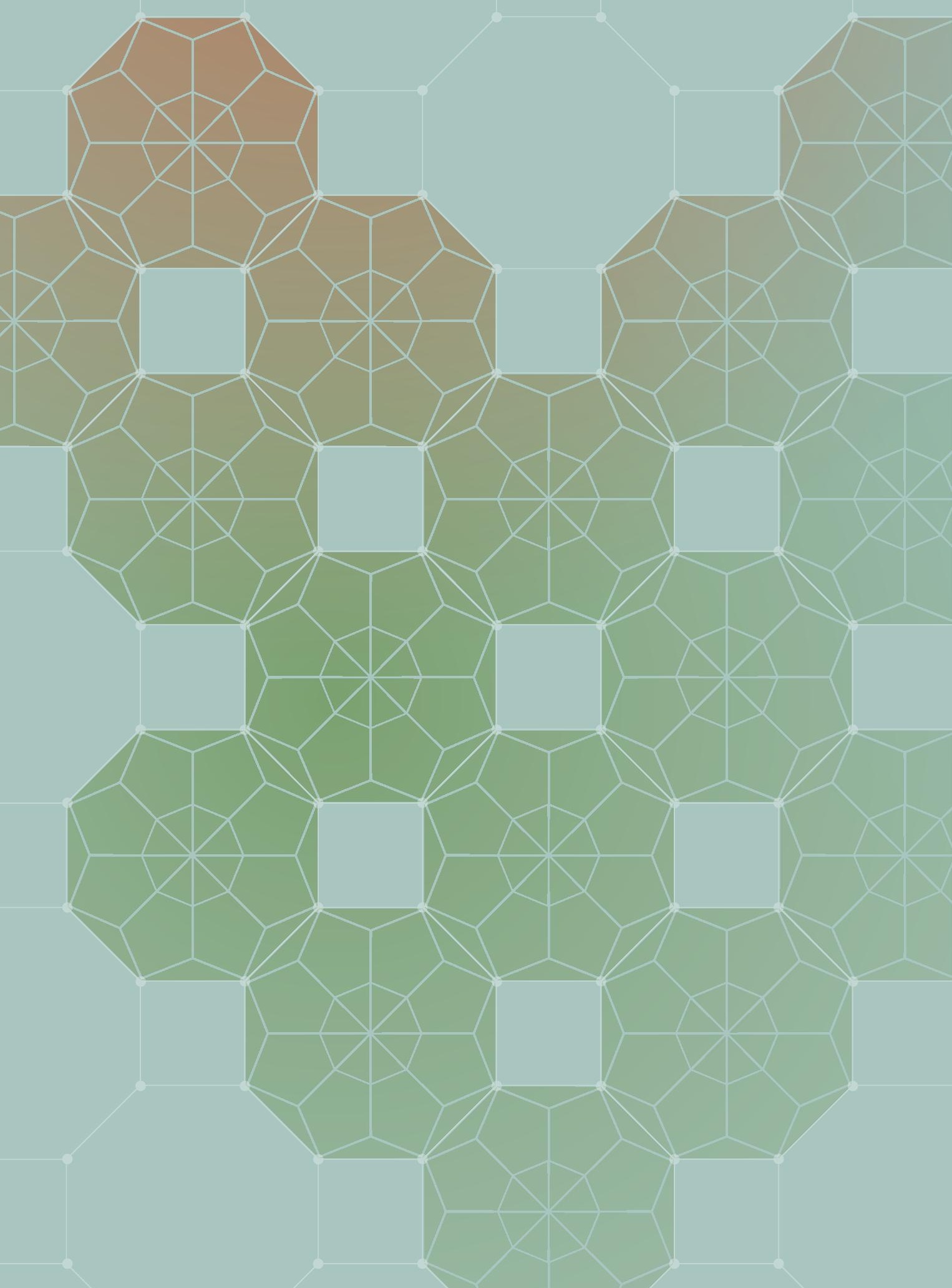





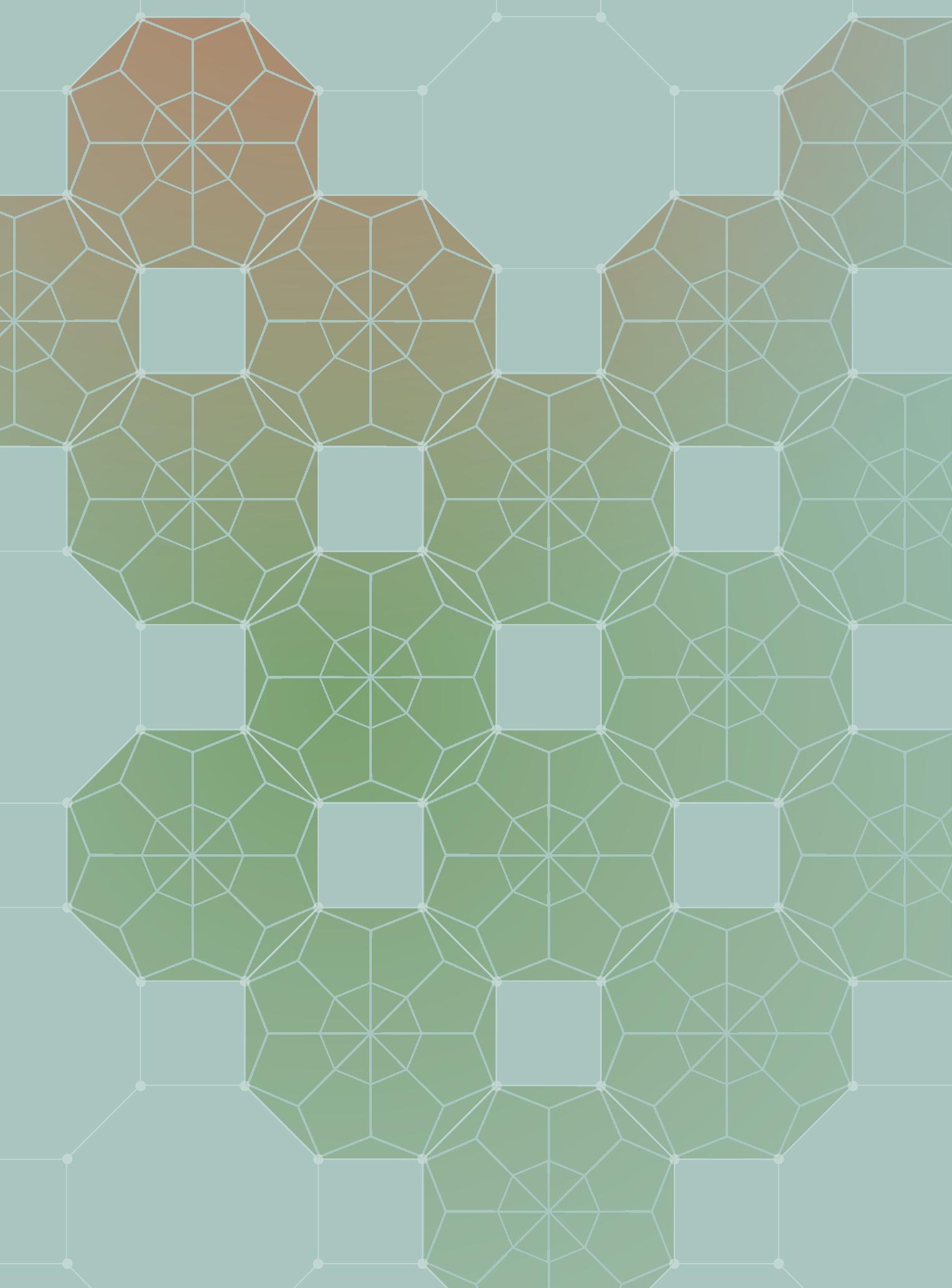




\section{CONCLUSIES}

\section{$6.1 \quad$ INLEIDING}

In dit proefschrift wordt onderzoek gedaan naar religie in een technologische cultuur. In Durkheims religiebegip is het fundamentele onderscheid tussen het sacrale en profane kenmerkend voor religie. De centrale vraag in dit proefschrift is in lijn daarmee: hoe krijgt het sacrale vorm in een technologische cultuur? Om die vraag te beantwoorden is de ontwikkeling van PAZIO als een probe van de technologische cultuur onderzocht. Lynch introduceert het begrip sacrale vorm, om recht te doen aan de verschillende uitwerkingen van het sacrale in maatschappelijke praktijken. Dat begrip is behulpzaam voor het onderzoeken van de PAZIO-probe. Daarnaast worden de Social Construction of Technologybenadering van socio-technische verandering en het Triple I-model voor praktijkonderzoek gebruikt om de ontwikkeling van PAZIO te onderzoeken. In de ontwikkeling van PAZIO heb ik de co-constructie van technologie en achtereenvolgens geloof, rituelen en gemeenschap in relatie tot het sacrale geanalyseerd.

In dit afsluitende hoofdstuk worden allereerst de inzichten uit de empirische hoofdstukken samengebracht en de relevantie van het sacrale voor een goed begrip van een technologische cultuur inzichtelijk gemaakt. Het onderzoek leidt tot twee belangrijke inzichten. Allereerst dat een technologische cultuur ook een religieuze cultuur is, met haar eigen impliciete sacraliteit. Ten tweede dat het sacrale richtinggevend is voor de socio-technische ontwikkelingen in deze cultuur. Op basis van het empirisch materiaal en deze twee inzichten wordt vervolgens een eerste aanzet voor een theorie van het Sacrale in een Technologische Cultuur (STC) ontwikkeld. Het geeft een lijn van denken die behulpzaam is bij het begrijpen en onderzoeken van de verwevenheid van technologie en religie in een technologische cultuur. 


\subsection{DE TECHNOLOGISCHE CULTUUR IS EEN RELIGIEUZE CULTUUP}

Szerszynski laat zien dat het sacrale door de eeuwen heen wel verandert, maar niet verdwijnt. ${ }^{421}$ Dat idee leidt tot de hypothese dat het sacrale ook in een technologische cultuur vindbaar en relevant is. In de technologische cultuur krijgt het individu een sacrale status en is er een groot vertrouwen in technologie als verlosser van het individu tegen de verschrikkingen van het leven. De waarde die gehecht wordt aan de autonomie van het individu en het vertrouwen in verlossend vermogen van technologie, zou Dooyeweerd de grondmotieven van de technologische cultuur noemen. Tegen die achtergrond ontwikkelt zich het gezondheidsportaal PAZIO.

De PAZIO-probe laat zien dat er een co-constructie plaatsvindt van technologie en religie. Met PAZIO ontwikkelt zich een sacrale vorm van geloof, rituelen en gemeenschap, waarin het centrale thema de verlossing is van de belemmeringen van ziekte door technologie. Dat wordt scherp duidelijk in de PAZIO-film waarin het beeld wordt geschapen van de iconische patiënt mevrouw De Wolf. Zij wordt verlost van haar vrijheidsbeperkingen door het omnipotente gezondheidsportaal PAZIO.

De ontwikkeling van PAZIO en zijn sacrale vorm kent verschillende fases van verandering en stabiliteit. Daarin kristalliseren het geloof en de rituelen zich steeds verder uit en worden ze gedragen door een steeds verder groeiende gemeenschap. De sacrale vorm die zich hand in hand met het gezondheidsportaal PAZIO ontwikkelt, illustreert het belang en de dynamiek van religie in een technologische cultuur. De PAZIO-probe laat ook zien dat religie in een technologische cultuur een eigen inhoud en karakter heeft. De sacrale vorm rond PAZIO is gebouwd op een gemeenschap van ontwikkelaars, pleitbezorgers, financiers en gebruikers die geloven in de meerwaarde van PAZIO. Die meerwaarde is gegrondvest in een geloof in de waarde van gezondheid en autonomie van het individu als hoogste goed. Technologie is het middel is om de individuele patiënt te verlossen van beperkingen en belemmeringen die (chronische) ziekte met zich meebrengen. Daartoe worden nieuwe rituelen ontwikkeld, waarmee het zorgportaal onderdeel wordt van de behandelrelatie tussen zorgverlener en patiënt.

De religie van de technologische cultuur is goed te beschrijven. Ze heeft alle karaktertrekken van een religie, maar heeft tegelijkertijd ook een bijzonder eigen karakter: in de technologische cultuur wordt religie 
niet als zodanig herkend of benoemd. Sterker nog: de technologische cultuur wordt in het algemeen als expliciet seculier gepresenteerd. De religie van de technologische cultuur is zoals Pärna het noemt implicit religion. ${ }^{422}$ De gedeelde overtuigingen en idealen zijn niet uitgewerkt in een formele geloofsleer of dogmatiek, de rituelen worden niet als zodanig beschreven of uitgevoerd. Anders dan veel expliciete religies, verwijst de religie van de technologische cultuur ook niet naar een hogere macht die deze wereld overstijgt, het sacrale wordt gevonden in deze wereld: in het individu en de verlossende technologie. Het transcendente is afwezig, de religie van de technologische cultuur erkent slechts een immanente orde. ${ }^{423} \mathrm{Het}$ impliciete en immanente karakter maakt dat deze religie niet zonder meer zichtbaar is in de technologische cultuur, waardoor die cultuur als seculier beschouwd wordt. Dat geeft de blinde vlek in het denken over de technologische cultuur en haar socio-technische dynamiek.

\subsection{DE RICHTINGGEVENDE ROL VAN HET SACRALE IN DE TECHNOLOGISCHE CULTUUR}

Het technologieonderzoek heeft laten zien dat technologieontwikkeling geen lineair, teleologisch of autonoom proces is. ${ }^{424}$ Technologische ontwikkeling is naadloos verweven met sociale en culturele ontwikkelingen. Het is een heterogeen en contingent proces, dat niet noodzakelijk gestuurd wordt door rationaliteit en techno-logica, maar veel meer een samenspel is van onder meer sociale, economische en culturele van machten, krachten en factoren. ${ }^{425}$ In het technologieonderzoek wordt dan ook gesproken van socio-technische verandering en niet zozeer van technologische ontwikkeling. De beschrijving van die socio-technische verandering schetst een beeld van een utilitair krachtenspel met een wat machiavellistisch karakter en een contingent resultaat. De vraag kan echter gesteld worden of de veranderingen daarmee overgeleverd zijn aan een wat opportunistisch machtsspel en of het resultaat niet meer dan een samenloop van de sociotechnische omstandigheden is. Is socio-technische verandering stuurloos of krijgt ze richting? 
Met Durkheim kunnen we de belangen, praktische voordelen en machtsverhoudingen die onmiskenbaar een rol spelen in de sociotechnologsche verandering, als profane factoren duiden en vervolgens de vraag naar het sacrale stellen. Welke rol spelen, idealen, waarden en overtuigingen? De sacrale benadering laat zien dat socio-technische ontwikkelingen weliswaar niet op een vooraf vastliggend technologisch resultaat aansturen, maar dat dergelijke processen wel degelijk waarden gedreven zijn en daardoor vorm en richting krijgen.

Het sacrale geeft richting aan socio-technische veranderingen. Het sacrale is er onderdeel van de socio-technische praktijk en ontwikkelt zich met die praktijk. Er is sprake van co-constructie van de sociotechnische praktijk en de sacrale vorm. In dat co-constructieproces is het sacrale een bron van inspiratie voor en integratie van socio-technische veranderingen. Zo is het sacrale richtinggevend voor socio-technische verandering en verdient het expliciete aandacht in analyse van dergelijke veranderingen. Het sacrale moet, in de analyse van het veranderproces, echter niet worden opgevat als een extrinsieke verklaring, een deus ex machina, of een gegeven factor. Het sacrale is immers onderdeel van de verandering en daarmee een te bestuderen factor om de co-constructie van socio-technische praktijken en sacrale vormen te begrijpen. Hoe kunnen we deze co-constructie onderzoeken en begrijpen? Dat vraagt om een theorie waarin ruimte is voor het sacrale als richtinggevende factor zonder in essentialisme te vervallen.

\subsection{THEORIE VAN HET SACRALE IN EEN TECHNOLOGISCHE CULTUUR}

\subsubsection{SCOT EN HET SACRALE}

Hoe kunnen de observaties uit dit onderzoek worden vertaald in een theorie over de werking van het sacrale in de technologische cultuur? Een dergelijke theorie van het Sacrale in een Technologische Cultuur (STC) moet niet alleen een begrippenapparaat bieden, maar ook een perspectief op de aard en dynamiek van de technologische cultuur. Het theoretisch perspectief moet recht doen aan de observaties en inzicht geven in de conditie van en ontwikkelingen in de technologische cultuur. Haar waarde ligt in het bieden van een analytisch kader en het vermogen om verbanden te leggen en behulpzaam te zijn bij het stellen van nieuwe vragen. Daarnaast kan zo'n theorie idealiter behulpzaam zijn bij het ontwikkelen van handelingsperspectieven. Om zo een theorie te ontwikkelen, hoeven we allerminst bij nul te beginnen. In deze studie is intensief gebruik gemaakt van TIM, SCOT en Durkheims benadering van 
het sacrale. Ze hebben hun waarde bewezen en bieden een stevige basis om op verder te bouwen.

De analyse van de PAZIO-ontwikkeling laat een afwisselend patroon zien met fases van stabiliteit en verandering. De stabiele fases zijn goed te beschrijven met het Durkheimiaans begrippenapparaat. Er is dan sprake van een sacrale vorm van een sociale gemeenschap met een gedeeld geloof en gedeelde rituelen. In die sacrale vorm vormen de onderdelen een geheel en ontstaat betekenis en stabiliteit. De gedeelde uitgangspunten, overtuigingen en idealen vormen vanzelfsprekende richtinggevers. Er ontstaat inspiratie voor innovatie.

Die inspiratie voor innovatie geeft zowel richting aan als ruimte voor vernieuwing. De richting mag duidelijk zijn, maar de ruimte die daarmee betreden wordt is open. Om de dynamiek van de veranderingsfase te beschrijven biedt SCOT een bruikbaar begrippenapparaat. Verschillende relevante sociale groepen hebben hun eigen interpretaties voor de invulling van de vernieuwing. De open ruimte biedt de relevante sociale groepen de gelegenheid om hun eigen expertises, overtuigingen en idealen in te brengen. Om tot een nieuwe stabiele praktijk te komen moet een nieuwe sacrale vorm geconstrueerd worden. Daarin spelen naast profane belangen, sacrale motieven een belangrijke rol. Het vraagt om integratie van geloof, hoop en idealen van de relevante sociale groepen in een sacrale vorm.

De SCOT-benadering van socio-technische ontwikkelingen en Durkheims sacrale benadering van religie delen een belangstelling voor sociale processen en zien daarbij beide het belang van mensen en hun sociale verbanden, narratieven en activiteiten. Zo heeft SCOT aandacht voor relevante sociale groepen en Durkheim voor morele gemeenschappen. SCOT kijkt naar technologische frames die bestaan uit theorieën, methoden, handelingen, gewoonten en manieren om zaken aan te pakken. Durkheim heeft aandacht voor geloof en rituelen die samen een religieus frame voor gemeenschappen vormen.

Het verschil tussen SCOT en Durkheim zit erin dat SCOT ontwikkeld is om technologieontwikkeling te bestuderen en Durkheims benadering religie als sociale praktijk onderzoekt. Waar SCOT een theorie is voor socio-technische verandering, geeft Durkheims sacrale benadering van religie een theorie voor sociale stabiliteit met als basis religie. SCOT en Durkheim vullen elkaar dan ook goed aan. SCOT focust op sociale verandering, Durkheim biedt een perspectief op sociale stabiliteit. Daarbij legt SCOT de nadruk op technologie en Durkheim op religie. Durkheim introduceert het fundamentele onderscheid tussen het sacrale en profane. Dat onderscheid is geen autonoom gegeven, maar mensenwerk. Het onderscheid tussen het sacrale en profane is in analytische zin dan ook 
dynamisch, maar wordt door mensen die onderdeel zijn van de cultuur beleefd als gegeven, vanzelfsprekend en onveranderlijk. ${ }^{426}$ Voor een cultuur is het onderscheid tussen sacraal en profaan fundamenteel en het bepaalt de orde van de dingen en de idealen, ambities en zorgen van een samenleving. Durkheims onderscheid tussen het sacrale en profane is op hanteerbare wijze uitgewerkt in het idee van sacrale vormen. Dit idee van sacrale vormen en het technologisch frame dat SCOT biedt, vullen elkaar goed aan (zie tabel 6.1). Een sacrale vorm legt de basis voor een intrinsiek en te onderzoeken waardensysteem dat richting geeft aan verandering en stabiliteit van praktijken.

\begin{tabular}{|c|c|c|}
\hline & SCOT & DURKHEIM \\
\hline Onderwerp & Verandering & Stabiliteit \\
\hline Verklaring & Technologisch frame & Sacrale vorm \\
\hline \multicolumn{3}{|l|}{ Elementen: } \\
\hline - Narratieven & Betekenisflexibiliteit & Geloof \\
\hline - Activiteiten & Handelingen rond artefacten & Rituelen \\
\hline - Sociale verbanden & Relevante Sociale Groepen & Gemeenschap \\
\hline
\end{tabular}

TABEL 6.1 Vergelijking SCOT en Durkheims theorie van het sacrale.

\subsubsection{SOCIALE VERBANDEN, NARRATIEVEN EN ACTIVITEITEN}

Om te komen tot een eerste uitgewerkte aanzet voor een theorie van het sacrale in een technologische cultuur, wordt gekeken naar de dynamiek van achtereenvolgens de sociale verbanden, narratieven en rituelen in de ontwikkeling van PAZIO. Op basis van het werk van Durkheim, het TIM en SCOT worden theoretische bouwstenen ontwikkeld voor het verklaren en beschrijven van deze dynamieken. 


\section{Sociale verbanden}

In Durkheims sacrale benadering en in SCOT spelen sociale verbanden een essentiële rol. Mensen zijn de dragers van narratieven en activiteiten en zij ontwikkelen deze in sociale verbanden. Technologische ontwikkelingen en religieuze praktijken zijn mensenwerk. Technologie en religie kunnen niet ontstaan zonder relaties, organisaties, gemeenschappen of coalities; ze kunnen niet bestaan zonder sociale verbanden. De ontwikkeling van PAZIO is onvoorstelbaar en onbeschrijfelijk als we de rol van mensen daarin niet opnemen.

In SCOT wordt het concept relevant social group geïntroduceerd. Dat zijn de groepen mensen die hetzij in de ogen van de deelnemers, hetzij in de ogen van de onderzoeker een relevante rol spelen in de socio-technische ontwikkeling. Relevante sociale groepen hebben vaak een eigen perspectief of interpretatie van een socio-technische ontwikkeling, de betekenisflexibiliteit. In de SCOT-benadering wordt gezocht naar de verschillende groepen mensen en de diversiteit van hun perspectieven op een ontwikkeling.

Waar SCOT vertrekt vanuit diversiteit en sociale verscheidenheid, is Durkheim op zoek naar de basis voor sociale eenheid en stabiliteit. Hij maakte zich zorgen over de sociale stabiliteit in een moderniserende samenleving ${ }^{427}$ en zocht antwoord op de vraag wat een gemeenschap bijeenhoudt en wat mensen verbindt. Hij vindt het antwoord in religie: de gemeenschap ontwikkelt zich hand in hand met het sacrale. Durkheim realiseert zich dat de sociale stabiliteit van een gemeenschap altijd tijdelijk is. Het sacrale is voor hem een bron voor sociale stabiliteit, maar ook een motivatie voor sociale verandering. SCOT heeft ook oog voor sociale stabiliteit en gemeenschapsvorming en beschrijft deze in termen van stabiliseringsprocessen.

Als socio-technische verandering plaatsvindt, zullen de diverse relevante sociale groepen een nieuwe stabiele sociale gemeenschap moeten vormen. Vanuit zo'n gemeenschap kan op haar beurt de behoefte of inspiratie voor verandering ontstaan, waardoor de gemeenschap haar stabiliteit verliest en er ruimte ontstaat om tot een nieuw sociaal verband te komen. Door Durkheims gemeenschap en SCOTs relevante sociale groepen te combineren ontstaat een nieuw dynamisch model: vanuit de relevante sociale groepen vormt zich een stabiele gemeenschap en bij verandering ontstaat er ruimte voor meerdere relevante sociale groepen om een rol te spelen. De sociaal-sacrale dynamiek kan als volgt worden geschetst (zie fig. 6.1): 


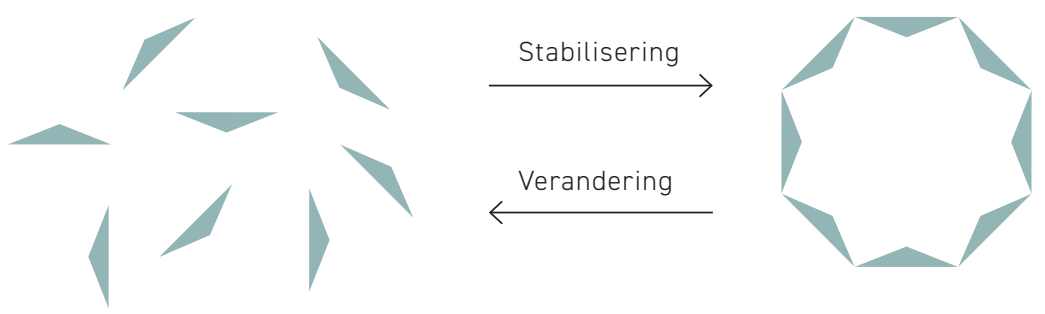

FIGUUR 6.1 Sociaal-sacrale dynamiek.

In de ontwikkeling van PAZIO is gemeenschapsvorming een belangrijk onderdeel. In de ontwikkeling zijn verschillende fases te onderscheiden waarin de sociale verbanden zich herorganiseren en zich ontwikkelen tot nieuwe gemeenschappen. De ontwikkeling begint met een kleine, informele groep rond het UMCU, die vervolgens uitgebreid wordt tot een formele projectorganisatie met stuurgroep en projectteam, en via missiewerk komt tot een gemeenschap die het PAZIO-project omarmt en steunt. Interessant is de rol van de patiënt in deze ontwikkeling. Die is nauwelijks fysiek of inhoudelijk betrokken, maar speelt wel een belangrijke rol. Als 'sociale groep' is de patiënt weinig relevant, maar op een symbolisch niveau levert ze een belangrijke narratieve bijdrage: ze is een icoon. De implementatie van PAZIO binnen het Leidsche Rijn Julius Gezondheidscentra in Vleuterweide zorgt voor nieuwe relevante groepen rond PAZIO, bestaande uit verschillende zorgverleners, waardoor gevestigde sociale verbanden rond PAZIO (en binnen LRJG) worden opgeschud en zich moeten reorganiseren.

\section{Narratieven}

De verhalen over PAZIO krijgen vorm in zaken als projectplannen, subsidieaanvragen, films, convenanten, maar ook in symbolen en iconen bijvoorbeeld in de vorm van logo's en 'de patiënt'. Zonder dergelijke narratieve elementen is communicatie niet mogelijk en kan er niet worden gewerkt of samengewerkt. Hoewel de op papier gestelde narratieven een technisch of zakelijk karakter hebben, geven ze desondanks ook een doorkijkje in de ambities, idealen en overtuigingen van de betrokkenen bij het project. De narratieve onderdelen van PAZIO tonen haar sacrale elementen en maken daarmee de drijvende kracht achter de ontwikkeling zichtbaar. 
In de SCOT-benadering spelen narratieve elementen een belangrijke rol. In het verlengde van de analyse van de relevante sociale groepen rond een socio-technische ontwikkeling, richt ze de aandacht op de verschillende interpretaties van die ontwikkeling door die groepen. Zo ontstaat er betekenisflexibiliteit tussen de groepen, bestaande uit verschillende verhalen over de ontwikkeling. Een relevante sociale groep interpreteert een ontwikkeling of artefact op basis van bijvoorbeeld eerdere ervaringen, belangen, ambities en overtuigingen. Met de ontwikkeling van de nieuwe socio-technische praktijk kristalliseert naast de gemeenschap ook het technologisch frame rond de socio-technische praktijk steeds verder uit. De betekenisflexibiliteit neemt af en de inhoudelijke kracht en het draagvlak onder de sociale groepen van het technologisch frame neemt toe.

Theoretisch is in het technologisch frame alle ruimte voor geloofselementen, zoals idealen, ontologie, verwachtingen en hoop. In de praktijk worden dergelijke aspecten door onderzoekers weinig opgenomen in de technologische frames. Veelal wordt gekeken naar profane aspecten als praktische problemen, regels, belangen en technische methoden. Maar de betekenisflexibiliteit en het technologische frame in een socio-technische ontwikkeling worden in de praktijk opgebouwd uit zowel profane als sacrale narratieve elementen. In de ontwikkeling van PAZIO spelen idealen, overtuigingen en ambities een belangrijke rol. Dat wordt goed zichtbaar in de PAZIO-film waarin PAZIO als een omnipotent portaal wordt gepresenteerd en mevrouw De Wolf tegelijkertijd tot een te verlossen iconische patiënt wordt gemaakt. Een dergelijke sacrale co-constructie van slachtoffer en verlosser is essentieel om de socio-technische dynamiek te begrijpen. Om de ontwikkeling van PAZIO goed te kunnen analyseren en doorgronden, is aandacht voor sacrale elementen in de ontwikkeling van het technologisch frame dan ook van groot belang. Oog voor het sacrale maakt dat niet alleen de letter, maar ook de geest van de narratieven en de ontwikkeling recht gedaan wordt.

Durkheims benadering zet juist de sacrale elementen in het verhaal centraal. Durkheim zoekt net als bij gemeenschappen ook in het narratief naar de eenheid en stabiliteit. Het basale verhaal voor iedere gemeenschap ligt bij Durkheim in het onderscheid dat in die verhalen geconstrueerd wordt tussen het profane en het sacrale. Particuliere belangen en doelen zijn in die benadering profaan en alledaags, gedeelde idealen en ambities zijn sacraal en buitengewoon. Het gedeelde geloof in het sacrale is een basis voor gemeenschapsvorming. Dooyeweerd zou zeggen: het sacrale ontsluit het sociale. Uit de betekenisflexibiliteit rond een artefact of praktijk moet een gedeeld geloof ontstaan om tot een stabiele praktijk te komen. Dat is meer dan recht doen aan al dan niet gerechtvaardigde belangen van stakeholders, het gaat om de ontwikkeling van een gedeeld narratief tussen de stakeholder over het artefact. Vanuit een dergelijk 
door een gemeenschap gedeeld geloof kunnen dan weer nieuwe verhalen met idealen ontstaan en narratieve aanzetten tot veranderingen ontstaan.

De relatie tussen de narratieve concepten van de verschillende benaderingen is als volgt te schetsen (zie figuur 6.2):
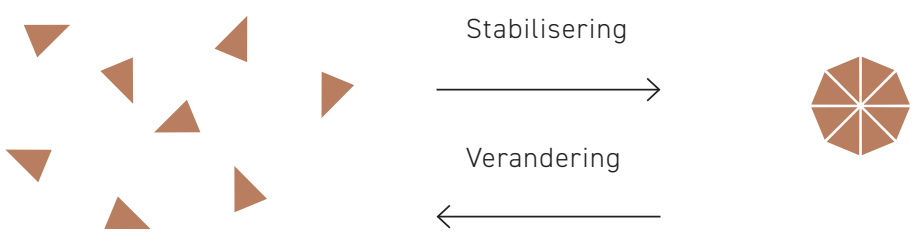

FIGUUR 6.2 Narratief-sacrale dynamiek.

In de ontwikkeling van PAZIO is zichtbaar hoe een sacraal geloof zich hand in hand met de gemeenschapsvorming ontwikkelt tot een socio-technisch geheel. Vanuit de particuliere belangen vormt zich met de ideeën over de technologie ook een sacraal geloof in de te verlossen iconische patiënt en de verlossende omnipotente technologie.

De implementatie van PAZIO bij LRJG is ook een illustratie van het belang van het sacrale in socio-technische ontwikkelingen. Bij de implementatie komen twee morele gemeenschappen, die van PAZIO en van LRJG, met ieder hun eigen sacrale geloof samen. Om tot een nieuwe gemeenschap en gedeeld sacraal verhaal te komen moeten bestaande narratieven als het ware smelten en stollen rond een nieuw sacraal ideaal. Het PAZIO-ideaal van het centraal stellen van de patiënt en de sacrale status van de behandelrelatie binnen LRJG hervormen zich in de praktijk tot een sacrale vorm, waarin de patiëntgerichte service centraal komt te staan in het nieuwe sacrale verhaal.

\section{Activiteiten}

Een praktijk bestaat niet alleen uit de verhalen die mensen vertellen of teksten die mensen gebruiken, ze bestaat ook uit activiteiten die mensen uitvoeren. Activiteiten zijn doelgerichte handelingen, die vorm krijgen in een samenspel tussen mensen, artefacten, plaats en tijd. 
Bij activiteiten gebruiken mensen vrijwel altijd artefacten, zoals instrumenten, objecten en apparaten. Dat is het meest zichtbaar in processen die om de ontwikkeling, productie of het gebruik van artefacten draaien. Te denken valt aan technologische ontwikkeling of productieprocessen waarin materialen, technologieën en instrumenten worden gebruikt om tot een bepaald artefact te komen. Zo'n artefact kan bijvoorbeeld een mechaniek zijn (een klok), een gekweekt gewas (aardappel) of een digitaal product als een programma of online afbeelding. Ook religieuze activiteiten kennen het gebruik van artefacten zoals keppeltjes, avondmaalsbekers, gebedsmolens of op grotere schaal moskeeën en tempels.

Zowel in productieprocessen als in religieuze activiteiten is het van belang dat handelingen in de juiste volgorde gebeuren en afgestemd worden op het sacrale. Zo kent de aardappelteelt haar seizoenen en is er een tijd om aardappels te poten en een tijd om ze te rooien. Het spreekwoord 'men moet het ijzer smeden als het heet is' heeft niet alleen een overdrachtelijke betekenis: ijzer smeden vraagt om timing. Religies kennen hun feestdagen en jaarcycli en concrete religieuze handelingen, zoals het avondmaal, zijn zorgvuldig in volgorde en timing georganiseerd. Zo ligt vast dat het brood voor de wijn gaat.

Activiteiten kennen hun plaats en verplaatsingen. Aardappels groeien niet overal, ze moeten in vruchtbare grond geplaatst worden. Het smeden van ijzer vraagt om de creatie van een specifieke robuuste omgeving waar voldaan wordt aan technische randvoorwaarden, veiligheidseisen en de beschikbaarheid van energie en beheersbare omstandigheden om hoge temperaturen te genereren en te controleren. En hoewel religieuze handelingen met meer of minder technische randvoorwaarden en decorum kunnen worden uitgevoerd, doet de locatie ertoe. Kerken, moskeeën en tempels zijn dragers van schoonheid, status of gezag en een huis voor de gemeenschap.

Naast de organisatie van artefacten, tijd en plaats, worden in activiteiten ook de verhoudingen en rolverdeling tussen de mensen onderling georganiseerd. Er zijn hele managementscholen opgezet om teamwerk te organiseren en optimaliseren, maar ook zonder die input verdelen mensen taken en ontstaan verhoudingen. Afstemming en samenwerking zijn vaak even belangrijke als vanzelfsprekende onderdelen in activiteiten. Dat geldt in sport, zorg, onderwijs, wetenschap, kerk, cultuur en samenleving. Activiteiten staan niet op zichzelf, maar vormen in samenhang een praktijk waarin mensen handelen en functioneren.

In SCOT-analyses zijn activiteiten onderdeel van het technologische frame. Daarin is bijvoorbeeld ruimte voor procedures, technieken en gewoonten maar ook regels, afspraken en belangen waarmee mensen hun activiteiten vormgeven. SCOT heeft daarbij een bijzondere belangstelling 
voor artefacten. SCOT analyseert immers de socio-technische ontwikkelingen rond een specifiek artefact. Het artefact staat daarbij centraal en is het analytisch kristallisatiepunt. Naast het artefact dat in de analyse centraal staat spelen ook andere artefacten en hun gebruik of toepassing een rol in het technologische frame. Artefacten zijn immers verbonden aan de activiteiten en manieren van werken van mensen, in het geval van SCOT: relevante sociale groepen.

Een technologisch frame bevat alles wat mensen gebruiken om de praktijk rond een artefact vorm te geven. Dat maakt het empirisch een goed te onderzoeken concept. Het geeft echter geen inzicht in de vraag waarom juist deze componenten van belang zijn voor de praktijk. Er is geen verbindende of onderscheidende component, buiten de verbondenheid aan het artefact.

Durkheim zoekt naar de gemene deler in de activiteiten van mensen, naar hoe activiteiten stabiel worden en waar deze stabiliserende werking op gebaseerd is. Hij concludeert dat het rituelen zijn die voor stabiliteit zorgen. Rituelen zijn activiteiten die orde scheppen doordat ze in het handelen tijd, ruimte, mensen en artefacten organiseren rond het sacrale. Durkheim maakt een onderscheid tussen alledaagse profane activiteiten en rituele activiteiten die het sacrale ontsluiten.

Profane activiteiten kunnen van groot belang zijn voor een mens of samenleving, maar niet noodzakelijk gebonden aan specifieke tijden, plaatsen, artefacten of mensen. Ze kunnen een utilitair nut hebben, maar zijn verder weinig gericht, georganiseerd en geformaliseerd. Sacrale activiteiten gaan het alledaagse voorbij en kennen een buitengewone oriëntatie op het sacrale. Ze worden gevoed en gericht door hoop, idealen en overtuigingen en ontsluiten het sacrale.

Aan de hand van verschillende maaltijden en manieren van eten kan het verschil tussen profane en sacrale activiteiten geilllustreerd worden. Het eten van een snack op het treinstation stilt de lekkere trek onderweg. Tegelijkertijd dient het geen hoger doel dan die acute individuele behoeftebevrediging. ${ }^{428}$ Het protestantse heilig avondmaal, de rooms-katholieke eucharistie of de seideravond ${ }^{429}$ in het Jodendom zijn van een heel andere orde. In die maaltijden doet de biologische trek er niet of nauwelijks toe, die maaltijden hebben een sacrale oriëntatie. Ze representeren verlossing en verwachting van verlossing. Ze kennen een strikte orde en organisatie en zijn niet op een willekeurige tijd en plaats 
uit te voeren. Dergelijke maaltijden worden weliswaar ook genuttigd, maar zijn bovenal een gemeenschappelijke viering en ontsluiting van het sacrale.

Rituelen gaan verder dan routines. Rituelen ontsluiten het sacrale en dienen een hoger doel dan bijvoorbeeld directe behoeftebevrediging of andere utilitaire doelen. Rituelen helpen de mens zich actief te verhouden tot het sacrale. Ze zijn onlosmakelijk verweven met geloof en gemeenschap. Rituelen staan niet op zichzelf, maar zijn onderdeel van de sacrale vorm. Zo valt op basis van SCOT en het werk van Durkheim ook voor activiteiten de dynamiek als volgt te schetsen (zie fig. 6.3):

Ulitaire activiteiten

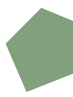

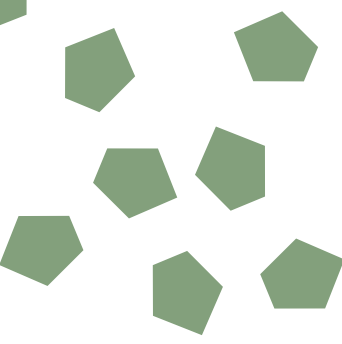

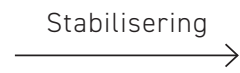

Verandering

FIGUUR 6.3 Activiteiten-sacrale dynamiek.

Bij de introductie van PAZIO binnen de LRJG-praktijk zien we dat de bestaande rituelen door de introductie van PAZIO veranderen. Dat gaat echter niet vanzelf. De claim dat mensen online los van plaats en tijd kunnen werken wordt niet vanzelfsprekend gerealiseerd. Het vraagt bijvoorbeeld om een keuze tegen HIS-integratie en voor Portaal-integratie. Het vraagt ook om nieuwe verbanden tussen personen in de vorm van authenticatie, om nieuwe rollen en relaties tussen patiënten en zorgverleners. En het vraagt om nieuwe vormen van planning en tijdsmanagement om zo online afspraken te synchroniseren met de praktijkagenda en openingstijden. Daarvoor is het nodig om naast het portaal PAZIO, nieuwe artefacten als DigiD, zelfmanagement tools, wachtwoorden, papieren handleidingen en digitale disclaimers te introduceren. Dat is meer dan een administratieve aanpassing of een vorm van business proces redesign 
om te komen tot efficiënte zorg. Hier is sprake van het ontwikkelen van nieuwe rituelen voor de sacrale behandelrelatie. De activiteiten hebben praktisch nut, maar worden vormgegeven en beoordeeld in het licht van die sacrale behandelrelatie. Die sacrale behandelrelatie moet worden gedigitaliseerd en dat vraagt om gedigitaliseerde rituelen. Met de digitale behandelrelatie wordt het ideaal van servicegerichtheid geco-construeerd rond de implementatie van PAZIO. Daarin vloeien de sacrale autonomie vanuit PAZIO en de sacrale behandelrelatie vanuit LRJG samen, zonder aan belang in te boeten.

PAZIO verstoort de stabiele rituelen rond de behandelrelatie doordat ze met de digitalisering een nieuwe ruimte biedt die nog niet is ingericht met rituelen. Pas als de digitale rituelen rond PAZIO uitkristalliseren ontstaat er een nieuwe stabiele praktijk, tot die tijd is er onrust en zoeken naar dat ritueel. Ondanks allerlei zakelijke prestatieafspraken en overeenkomsten tussen PAZIO en LRJG op managementniveau krijgt PAZIO geen toegang tot het sacrale primaire proces. Zelfs als de PAZIO-techniek begin 2010 klaar staat voor gebruik, weigeren zorgverleners PAZIO in te zetten, zolang de juiste rituelen ontbreken en PAZIO geen recht doet aan de sacrale behandelrelatie. Zolang de technische mogelijkheden van PAZIO niet ritueel (en in het geloof en de gemeenschap) geïntegreerd zijn, krijgen ze geen toegang tot de sacrale behandelrelatie. Daar veranderen profane zaken als praktische tijdswinst, financiële efficiëntie en prestatieafspraken niets aan. Pas als er een georganiseerde sacrale vorm ontwikkeld is, worden de techniek bruikbaar en de activiteiten stabiel.

\subsubsection{SACRALE VORMEN EN DYNAMIEK}

In de ontwikkeling van PAZIO zien we met betrekking tot de sociale groepen, verhalen en activiteiten een terugkerende dynamiek, waarbij vanuit verscheidenheid het sacrale op nieuwe wijze vorm krijgt en stabiliseert. In die transformatie vindt integratie plaats. De ontstane sacrale vorm biedt op haar beurt nieuwe inspiratie om verder te werken aan het ideaal waarmee verandering wordt ingezet. Het geloof, de gemeenschap en rituelen ontwikkelen zich zo hand in hand met de ontwikkeling van PAZIO.

Om de ontwikkeling van sacrale vormen te analyseren, bieden Durkheim en SCOT nuttige handvatten. Beide hebben inzichten en theorie ontwikkeld over verandering en stabiliteit. Durkheim legt daarbij de nadruk op het begrijpen van de stabiliteit van een samenleving en SCOT zoekt juist naar inzicht in de veranderdynamiek en legt daarbij de focus op technologie. In zekere zin bieden ze zicht op de twee kanten van de medaille. Ze gebruiken, zoals we hierboven zagen, dezelfde elementen (narratieven, activiteiten en sociale verbanden) om verandering en stabili- 
teit te verklaren. De combinatie van beide benaderingen biedt een nieuw perspectief waarin co-constructieprocessen gerelateerd worden aan de ontwikkeling van de sacrale vormen. Dat maakt het mogelijk de richting van socio-technische veranderingen te begrijpen.

Een sacrale vorm stabiliseert als er een geïntegreerde eenheid van geloof, ritueel en gemeenschap ontstaat. Voor het ontwikkelproces betekent dit dat er oog moet zijn voor de co-constructie van deze onderdelen in relatie tot het sacrale. Het sacrale wordt geconstrueerd met profane middelen. Mensen, dingen en rituelen mediëren het sacrale en krijgen daarmee zelf een meer of minder sacrale status. De dynamiek tussen mevrouw De Wolf en PAZIO is daarvan een mooie illustratie.

Vanuit de SCOT-benadering zou dit een klassiek voorbeeld van co-constructie van probleem (de vrijheidsbeperkingen van mevrouw de Wolf) en oplossing (het portaal PAZIO) zijn. De vraag die blijft liggen is waarom deze als reëel, legitiem en te prioriteren probleem en oplossing worden ervaren. SCOT verklaart het hoe maar niet het waarom van deze ontwikkelingsrichting, zoals beleefd door de relevante sociale groepen. Vanuit een constructivistisch perspectief is het methodologisch legitiem om geen a priori standpunten in te nemen over het ware, goede of schone en naar het constructieproces te kijken. Het is echter jammer dat er daarmee ook geen aandacht is voor het belang van deze drie in het constructieproces. Het co-constuctieproces lijkt dan zomaar een variant te worden op een filosofisch anything goes of een evolutionair schitterend ongeluk. Dat doet geen recht aan de het belang dat mensen hechten aan geloof, hoop en idealen en de impact daarvan op hun leven en samenleven. Tegelijkertijd heeft het weinig toegevoegde waarde als ze als een essentialistische grootheid of deus-ex-machina-achtige verklaring worden toegevoegd. De uitdaging is om de richting te verklaren, in plaats van deze slechts als verklaring op te voeren. Hoe kunnen we geloof, hoop en idealen meenemen in de analyse van het co-constructieproces zonder deze als losstaande richtinggevers op de ontwikkeling te plakken?

De sacrale vorm helpt om richting in socio-technische ontwikkelingen te zien en deze te verklaren binnen een constructivistisch kader. Het onderscheid tussen het sacrale en profane is te onderzoeken als een constructie in zichzelf. ${ }^{430}$ Een sacrale vorm geeft immers richting vanuit geloof, hoop en idealen maar trekt ook mee in de verandering en wordt geco-construeerd. De co-constructie van mevrouw de Wolf en PAZIO komt in een nieuw licht te staan als we zien dat ze voortkomen uit dezelfde bron: de sacrale vorm waarin vrijheid door technologie het adagium is. 
Een co-constructie vindt niet in een sacraal vacuüm plaats, maar in een sacrale omgeving. In dit geval zijn gezondheid en autonomie door technologie de sacrale waarden die richting geven aan de co-constructie. Binnen die sacrale vorm van autonomie en gezondheid wordt het mogelijk dat mevrouw de Wolf het icoon van de te verlossen patiënt wordt en PAZIO zich tegelijkertijd ontwikkelt tot het toonbeeld van de verlossende technologie. Simultaan geven Mevrouw de Wolf en PAZIO in dit sacrale co-constructie proces een nieuw gezicht, een actuele betekenis en een verrassende interpretatie aan de sacrale waarden gezondheid, autonomie en technologie. Door aandacht te hebben voor de sacrale vorm krijgen we zicht op de richting van co-constructieprocessen en doen we recht aan de rol van het sacrale in de technologische cultuur naast haar profane aspecten.

De combinatie van SCOT en Durkheims benadering leidt tot een nieuw inzicht in de dynamiek van verandering en stabilisering van een socio-technische praktijk. De sacrale vorm is daarbij een verhelderende factor om zowel stabiliteit als verandering van een praktijk te begrijpen.

In hoofdstuk 2 werd al beschreven dat een stabiele sacrale vorm ontstaat in een samenspel tussen geloof, rituelen en de morele gemeenschap. Het sacrale is een emergente zaak, die ontstaat in een samenspel tussen geloof, gemeenschap en rituelen. Het geheel van die drie is meer dan de som der delen (zie figuur 6.4).

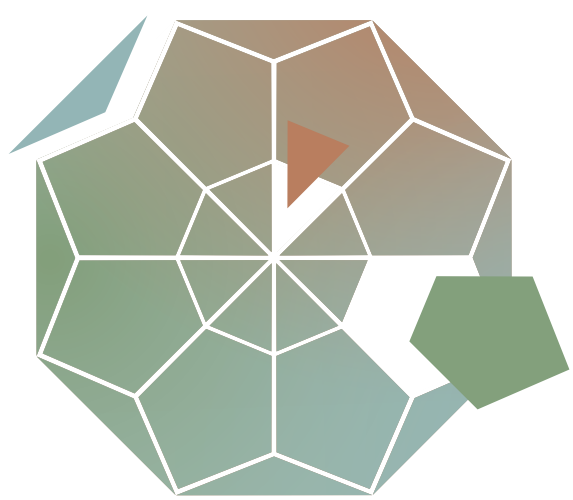

FIGUUR 6.4 Sacrale vorm.

Het onderscheid tussen het profane en sacrale brengt orde aan in de werkelijkheid. Ze vormt de basis voor ontwikkeling van kennis en ideeën over de werkelijkheid. Het sacrale is weinig vatbaar voor profane zaken. 
Of om een reclame van een creditcard te parafraseren: het sacrale is onbetaalbaar, voor het profane Eurocard Mastercard. ${ }^{431}$ Met het sacrale wordt orde aangebracht, ontstaan idealen en krijgt de banale werkelijkheid betekenis. Daarmee ontstaan de twee grote krachten van religie: het streven naar behoud van de sacrale orde en het werken aan het sacrale ideaal.

\section{Stabiliteit}

Vanuit SCOT wordt de ontwikkeling in de richting van een stabiele socio-technische construct beschreven in termen van stabilisatie waarmee een nieuw technologische frame uitkristalliseert. De betekenis van het artefact stabiliseert en de relevante sociale groepen vinden elkaar doordat de betekenisflexibiliteit rond de technologie afneemt. Er vormt zich een technologisch frame, met daarin elementen als technieken, methoden, probleemstellingen et cetera. Hoe de elementen zich tot elkaar verhouden en het technologische frame vormen wordt niet verder gespecificeerd. In de onderzoekspraktijk leidt dat tot een wat arbitraire en utilistische invulling van het technologisch frame. Daarmee krijgen we inzicht in het stabilisatieproces en het resultaat (de elementen van het technologische frame en een werkend artefact), maar geen verklaring voor de veranderingen die plaatsvonden en de ontstane stabiliteit.

De benadering van Durkheim kan een waardevolle aanvulling bieden op SCOT om het technologisch frame verder te doordenken en conceptualiseren. Het elementaire onderscheid dat Durkheim introduceert, is het onderscheid tussen het profane en het sacrale. Bij het profane gaat het om alledaagse, vaak utilitaire, zaken. Het sacrale is van een andere orde. Het gaat om het buitengewone, het sublieme, het ideale. De ideaalbeelden zijn nastrevenswaardig en geven richting aan hoe een gemeenschap de wereld ziet en begrijpt, waar ze op hoopt en hoe ze hoort te handelen. Er is ligt een groot taboe op het ter discussie stellen van het sacrale. In vrijwel alle tijden en culturen was er een goddelijke, sacrale vorm. In de technologische cultuur heeft de mens die plek ingenomen en lijkt er een taboe te zijn op het ter discussie stellen van de menselijke autonomie en zijn of haar technologisch vernuft.

Het sacrale geeft richting en betekenis aan het denken en doen van een gemeenschap. Het sacrale verklaart bijvoorbeeld hoe een stuk stof kan transformeren tot een vlag waarvoor men wil sterven. Het verklaart hoe een verzameling willekeurige individuen een morele gemeenschap kan vormen of hoe een alledaagse plant, dier of technologie wordt getransformeerd tot een heilig icoon of amulet waar alle hoop op gevestigd 
wordt. Het sacrale kan zo ook verklaren hoe een technologisch frame vanuit een diversiteit aan relevante sociale groepen, betekenisflexibiliteit en losstaande activiteiten eenheid en richting krijgt. Het sacrale is geen intrinsieke eigenschap van de hierboven genoemde vlag, dier, plant, technologie of gemeenschap zelf, het is een toegeschreven kwaliteit. ${ }^{432}$ Het sacrale wordt toegeschreven aan de alledaagse profane werkelijkheid en daaraan als een extra laag toegevoegd. Daarmee wordt ze een richtinggevend onderdeel van het begrip, de beschrijving en behandeling van de werkelijkheid. Dat maakt dat men bereid kan zijn om te sterven voor een vlag, een dier heiligverklaart of hoopt op verlossing door technologie.

Met behulp van het sacrale en de elementen geloof, rituelen en gemeenschap kan ook het technologisch frame beter worden begrepen en bestudeerd. In het STS-onderzoek vormt het technologisch frame op het eerste gezicht een willekeurige verzameling van narratieven en activiteiten rond een artefact. De sacrale vorm schept daarin orde en is de integrerende factor. Het frame van een gestabiliseerde praktijk is te begrijpen als een sacrale vorm waarin het geloof en de rituelen van een gemeenschap naadloos met elkaar verweven zijn en gericht zijn op het sacrale. Een dergelijke invulling van het frame maakt het meer een religieus dan technologisch frame. Het draait immers niet langer om de techniek, ze vindt haar oorsprong, doel en zin in het religieuze. De sacrale vorm zorg voor stabilisering van de socio-technische praktijk, zoals in figuur 6.5 geschetst.

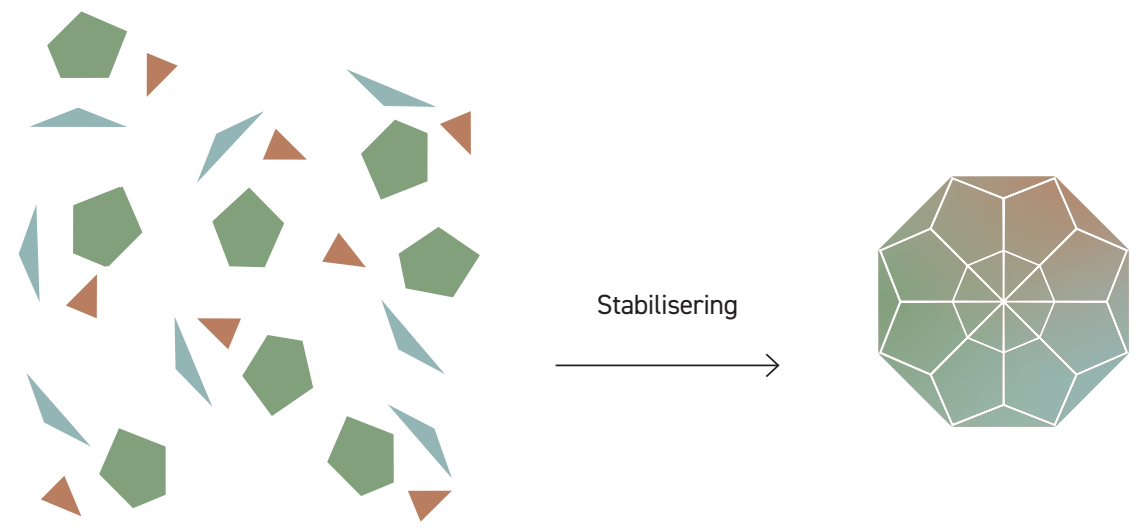

FIGUUR 6.5 Stabilisering. 


\section{Verandering}

SCOT besteedt veel aandacht aan verandering; Bijkers boek Of Bicycles, Bakelites and Bulbs heeft niet voor niets als ondertitel a theory of sociotechnical change. Opmerkelijk genoeg wordt aan de aanleiding voor verandering in het boek nauwelijks aandacht besteed. Verandering is voor Bijker een gegeven en onderzoeksobject dat geen verdere verklaring behoeft. De vraag 'waarom zouden mensen hun leven, samenleving of wereld willen veranderen?' komt niet aan de orde. Dat is een gemiste kans in de theorievorming.

Het antwoord op die vraag is even eenvoudig als complex: omdat het beter kan. Of preciezer: omdat de mens gelooft dat het beter kan en hij aan die verbetering denkt te kunnen en soms zelfs te moeten bijdragen. Dit eenvoudige antwoord wordt complex als we proberen te ontdekken wat onder beter verstaan wordt. Daarover verschillen de visies tussen mensen, gemeenschappen en culturen. De vraag wat een betere wereld is of hoe men een beter mens wordt kent vele antwoorden. Diepdoordachte en doorleefde antwoorden kan men bijvoorbeeld vinden in de wereldreligies en grote filosofieën. ${ }^{433}$ Ideeën over een betere wereld zijn geworteld in grondmotieven, idealen, verwachtingen en overtuigingen. In het geval van PAZIO ligt de inspiratie voor innovatie in het geloof in de waarde van autonomie van de mens en de mogelijkheden om die autonomie met technologie te versterken. Dat is een heel ander sacraal beeld dan bijvoorbeeld het boeddhistisch ideaal van het bereiken van het nirwana en het ontsnappen aan de maalstroom van het samsara door meditatie en onthechting. Of het christelijke ideaal: God lief hebben boven alles en je naaste als jezelf en daar vorm aan geven door te zingen, te bidden en goede werken te doen. De gemene deler tussen deze voorbeelden is, dat bij alle drie de bron voor verandering ligt in het sacrale, ook al wordt het sacrale in deze drie tradities inhoudelijk heel verschillend ingevuld. Daarbij is het niet alleen een verlangen, maar in de gegeven sacrale orde ook een opdracht om aan het goede of aan verbetering van leven, samenleven en de wereld te werken. Het is een missie die soms tot charitatieve activiteiten, soms tot technologische ontwikkeling en soms tot pogingen tot onthechting leidt. Dat alles in een heilig streven van de mens naar verlossing van de lasten van het leven.

Die sacrale vorm geeft voeding aan idealen en het streven van mensen. Ze geeft oorsprong, doel en zin aan het menselijk handelen en inspiratie voor innovatie. Een dergelijke inspiratie voor innovatie doorbreekt in meer of mindere mate de gevestigde orde en streeft naar 
het ideale. De sacrale vorm is naast innovatief ook disruptief en allerminst conservatief. De losmaking van de gevestigde orde zorgt ervoor dat er ruimte ontstaat voor nieuwe relevante sociale groepen met nieuwe ideeën, idealen en interpretaties en activiteiten om een plek te verwerven. In figuur 6.6 is dat schematische weergegeven.
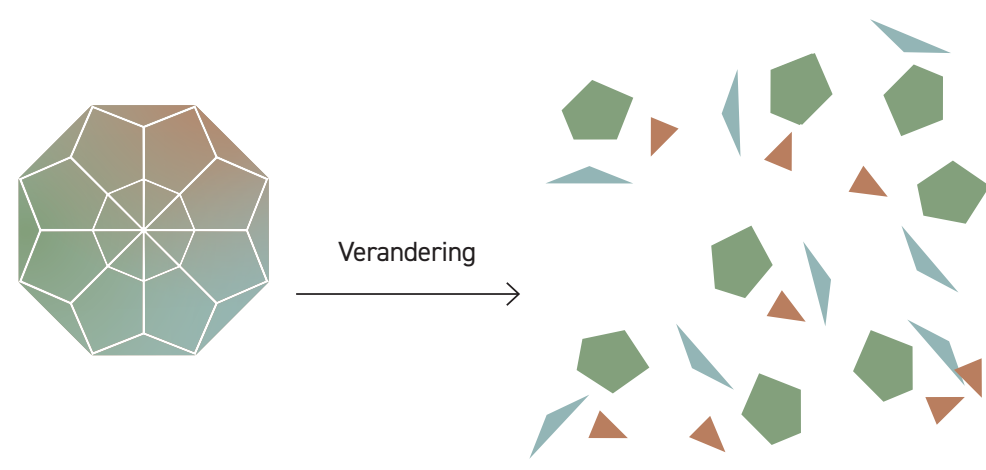

FIGUUR 6.6 Verandering.

De PAZIO-probe laat zien dat ook in een technologische cultuur religie een essentieel element is. Aandacht voor die religieuze kant van de technologische cultuur geeft analytische scherpte en doet recht aan het menszijn in een technologische cultuur. Een mens is een onvervreemdbaar religieus wezen, zoals ze overigens ook een onvervreemdbaar technologisch wezen is.

Religie is zowel een bron voor verandering als voor stabilisering, ze heeft zowel een innovatieve als conservatieve kant. Religie heeft de paradoxale neiging om zowel te begrenzen als ook om uit te dagen om door grenzen van het imperfecte heen te breken. Religie daagt een gemeenschap uit om zowel een betere wereld te (onder)zoeken als ook het goede te behouden. Het sacrale werkt als integrator en als inspirator, het is het cement voor de orde en de vlam voor verandering. Beide zijn nodig om tot ontwikkeling te komen. Socio-technische innovaties ontstaan vanuit de inspiratie die sacrale vormen bieden. Deze dragen ook bij aan het stabiliseren als er vernieuwing optreedt, waarin de morele gemeenschap, een coherent geloof en gedragen rituelen een geïntegreerde eenheid rond het sacrale vormen. 
Deze manier om techno-sacrale verandering en stabiliteit te begrijpen biedt een eerste aanzet voor een theorie van het Sacrale in een Technologische Cultuur. Ze maakt het mogelijk om de twee techno-sacrale dynamieken van verandering en stabilisering te herkennen, onderzoeken en begrijpen (zie fig. 6.7).
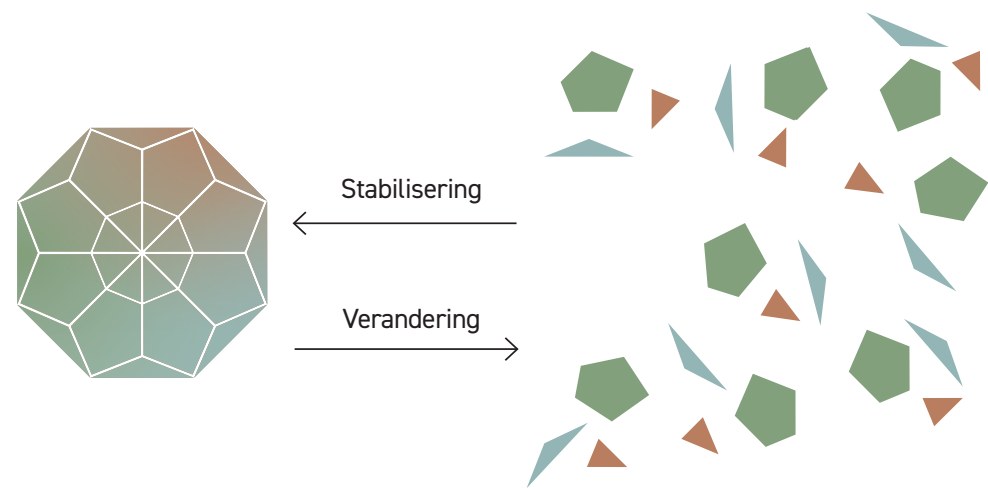

FIGUUR 6.7 Theorie voor het Sacrale in een Technologische Cultuur (STC).

\subsection{HANDVATTEN VOOR ONDERZOEK VAN HET SACRALE IN EEN TECHNOLOGISCHE CULTUUR}

Hoe kan een onderzoek naar de verwevenheden van technologie en religie worden aangepakt op basis van bovenstaande theorie van het Sacrale in een Technologische Cultuur? Ik schets verschillende praktische handvatten voor het doen van onderzoek naar narratieven, activiteiten, sociale verbanden, en naar het onderscheid tussen het sacrale en profane. Op basis van de co-constructie van deze elementen en het ontwikkelproces kunnen vervolgens de dynamiek van verandering en stabilisering gereconstrueerd worden.

\section{Onderzoek naar sacrale vormen}

Het onderscheid tussen het profane en sacrale is in de technologische cultuur grotendeels impliciet. De technologische cultuur wordt als religieus neutraal en seculier beschouwd, er zouden geen heilige huisjes zijn en sacraliteit zou iets van andere tijden en plaatsen zijn. Dat maakt 
het onderscheid tussen sacraal en profaan lastig te onderzoeken. Het seculiere karakter van de technologische cultuur betekent overigens niet dat godsdiensten en levensovertuigingen geen rol spelen. Godsdiensten en levensbeschouwingen worden echter als een privézaak beschouwd, die achter de voordeur en buiten het publiek domein behoren te blijven.

Tegelijkertijd zijn er zaken die een sacraal karakter hebben en juist een publieke en expliciete vorm hebben. Zo is de Universele Verklaring van Rechten van de Mens door haar niet-godsdienstige karakter juist in een seculiere cultuur een sacrale status. ${ }^{434}$ Andere pijlers voor de westerse seculiere technologische cultuur zijn bijvoorbeeld de Sustainable Development Goals ${ }^{435}$, de democratie, rechtstaat ${ }^{436}$ en grondwet ${ }^{437}$ met daarin bijvoorbeeld de vrijheid van meningsuiting en individuele autonomie. Het zijn de zaken waar men met goed fatsoen niet tegen kan zijn.

Er is daarnaast veel onderzoek gedaan naar de technologische cultuur en hoe daarin geleefd wordt. Het werk van Dooyeweerd en Szerszynski dat in hoofdstuk 1 al besproken werd, plaatst de technologische cultuur bijvoorbeeld in een breder cultureel perspectief waardoor haar eigenschappen scherper naar voren komen. Dergelijke cultuurstudies ${ }^{438}$ maken het veelal impliciete onderscheid tussen het sacrale en profane expliciet, zonder noodzakelijk ook de terminologie over te nemen. Op basis van de literatuur kan er veel geleerd worden over het sacrale in een technologische cultuur. Dat geeft een eerste handvat voor onderzoek naar het sacrale in de technologische cultuur.

Om dat inzicht in het onderscheid tussen het profane en sacrale inhoudelijk verder te preciseren in een specifieke casus is het sacrale van een technologische cultuur een te algemeen begrip. Ze vraagt om toespitsing en precisering voor het onderzoek naar concrete casus. Het begrip sacrale vorm is daarbij behulpzaam. De sacrale vorm helpt het onderzoek naar het sacrale in een concrete praktijk of in een probe van de technologische cultuur te operationaliseren, zonder daarmee de verbinding met een breder begrip van de cultuur en het sacrale te verliezen.

434 College voor de Rechten van de Mens, 'Universele verklaring van de rechten van de mens'.

435 United Nations, 'Sustainable development goals, 17 goals to transform our world'

436 Boutellier geeft aan dat de rechtsstaat een 'seculier sacrale status' heeft. Boutellier, Het seculiere experiment, 210. 437 Montesquieu Instituut, 'De Nederlandse grondwet'.

438 Zoals bijvoorbeeld Latour, Wij zijn nooit modern geweest; Taylor, A secular age; Achterhuis, De erfenis van de utopie; Borg, Zineconomie; Jasanoff en Kim, Dreamscapes of modernity: sociotechnical imaginaries and the fabrication of power; Boutellier, Het seculiere experiment. 
$\mathrm{Bij}$ het onderzoeken van sacrale vormen is aandacht voor narratieven, rituelen en sociale verbanden essentieel. Daarbij kunnen de volgende dichotomieën behulpzaam zijn:

\begin{tabular}{|c|c|c|}
\hline & PROFAAN & SACRAAL \\
\hline Sociale verbanden & Coalities o.b.v. particuliere belangen & $\begin{array}{l}\text { Morele gemeenschap o.b.v. gedeelde } \\
\text { waarden }\end{array}$ \\
\hline Narratieven & $\begin{array}{l}\text { Utilitaire en pragmatische } \\
\text { overwegingen }\end{array}$ & $\begin{array}{l}\text { Idealistische en ambitieuze } \\
\text { overtuigingen, grondmotieven }\end{array}$ \\
\hline Activiteiten & Alledaagse individuele handelingen & Gedeelde rituelen \\
\hline
\end{tabular}

TABEL 6.2 Dichotomieën voor onderzoek.

Deze dichotomieën moeten niet worden opgevat als a priori gegevens, maar als te onderzoeken en te verklaren onderscheidingen tussen het sacrale en profane in een specifieke casus en sacrale vorm. Het is van belang dat bovenstaande dichotomieën niet als absoluut genomen worden, maar slechts als heuristiek gebruikt worden. Relevante sociale groepen zijn bijvoorbeeld niet noodzakelijk en nooit alleen gericht op belangen, ze nemen vaak ook hun eigen eerder ontwikkelde inspiratie voor innovatie, sacrale waarden en overtuigingen mee. ${ }^{439} \mathrm{In}$ een fase van verandering zijn die nog niet geïntegreerd in een nieuwe gedeelde sacrale vorm. Er is dan nog geen gedeeld moreel kader tussen de relevante sociale groepen waardoor utilitaire en pragmatische factoren een meer prominente rol in het veranderproces krijgen. Een sacrale vorm bestendigt als er een geïntegreerde eenheid van geloof, ritueel en gemeenschap ontstaat. Voor het ontwikkelproces betekent dit dat er oog moet zijn voor de co-constructie van deze onderdelen in relatie tot het sacrale.

\section{Onderzoek naar sociale verbanden}

Bijker geeft twee vuistregels voor het identificeren en beschrijven van relevante sociale groepen: sneeuwballen en volg-de-actoren. ${ }^{440}$ 
Op basis van de sneeuwbaltechniek kan een lijst relevante sociale groepen worden samengesteld. De volg-de-actoren aanpak kan worden ingezet om de karakterisering van de relevante sociale groepen uit te werken. Hoe kan de groep omgeschreven en afgebakend worden? Zoals met veel kwalitatief onderzoek is het ontdekken en karakteriseren van de relevante sociale groepen geen lineair maar een iteratief proces. Dat geldt voor het identificeren en karakteriseren van relevante sociale groepen, maar ook voor de andere onderdelen van een casus. Het onderzoek heeft meer het karakter van een legpuzzel waaraan op meerdere plekken en manieren gewerkt wordt dan van een bouwpakket dat stapsgewijs aan de hand van een handleiding in elkaar wordt gezet. Belangrijk verschil met zowel het bouwpakket als een legpuzzel is dat bij STC-onderzoek de uitkomst en het inzicht ontstaat tijdens het onderzoek. Zo kan in de dataverzameling, analyse en beschrijving van een STC-casus de focus worden gelegd op een specifiek onderdeel (relevante sociale groepen, geloof, activiteiten etc.) of op een bepaalde fase (van inspiratie of stabilisatie), maar dat neemt niet weg dat tegelijkertijd ook data, informatie en inzichten worden opgedaan op andere onderdelen en fasen. Daarnaast krijgen de onderdelen en fasen pas waarde en betekenis als ze in het grotere geheel van de casus passen.

Als een socio-technisch construct verder uitkristalliseert, ontwikkelen de relevante sociale groepen zich tot een morele gemeenschap. Naast groepen zijn daarin ook rollen te onderscheiden. In de PAZIO-ontwikkeling was de patiënt in de persoon van mevrouw De Wolf een sacraal icoon. Daarnaast waren er missionaire voorgangers (zoals de stuurgroep en het projectteam), navolgers (zoals de steunbetuigers) en pragmatici (zoals PharmaPartners en Pharmeon). Het onderscheiden van dergelijke rollen is behulpzaam bij het ontwikkelen van inzicht in de dynamiek van de ontwikkeling. Ook het TIM geeft een praktisch bruikbare doorsnede van sociale groepen met ieder hun eigen bronnen van waarden. Professionals hebben hun professionele identiteit en beroepscodes, bij een praktijk betrokken partijen als financiers, inspecties en verzekeraars brengen eigen belangen en verantwoordelijkheden in, en vanuit een breder maatschappelijk perspectief worden grondmotieven en idealen over het goede leven en de samenleving ingebracht. De doorsnede die het TIM biedt kan worden gezien als een verfijning bij de benadering van relevante sociale groepen en hun betekenisflexibiliteit.

\section{Onderzoek naar narratieven}

Het sacrale heeft zowel een inspirerende als integrerende kant. Beide putten uit dezelfde narratieve bron. Hoe onderzoek te doen naar dergelijke narratieven? Dat vraagt om aandacht voor de achterliggende vooronderstellingen, idealen en ambities voor die inspiratie of integratie, zoals die terugkomen in de betekenisflexibiliteit van relevante sociale 
groepen of in de waarden van professionals, belanghebbenden en samenleving. Die geven inzicht in hoe een groep tegen de wereld aan kijkt, tegen de rol of opdracht van de mens daarin en ze geven inzicht in de hoop en verwachting die de mens daarbij mag hebben. Die aspecten kunnen we vertalen in drie vragen:441

- $\quad$ Een ontologische vraag: hoe wordt de werkelijkheid geordend?

- Een morele vraag: wat kan of behoort men te doen?

- $\quad$ Een existentiële vraag: wat mag men hopen of verwachten?

De antwoorden op die vragen geven inzicht in het sacrale geloof van groep. Deze kunnen worden ingezet als zoeklichten voor het ontdekken en analyseren van het sacrale geloof als inspiratiebron en integrator. In de dynamiek tussen verandering en stabilisatie spelen ook profane elementen een rol. Naast de sacrale vraag naar de zin, is daarom ook een vierde vraag naar het profane nut belangrijk om te onderzoeken.

De utilitaire vraag: wat zijn de belangen en het nut?

\section{Onderzoek naar activiteiten}

Hoe onderzoek te doen naar activiteiten? Een activiteit vormt zich door een samenspel van mensen en artefacten in de tijd en ruimte. Voor het beschrijven van activiteiten is het goed om een breedte aan categorieën te analyseren en te bestuderen hoe verschillende onderdelen een geheel vormen in een activiteit. Analytisch is het behulpzaam om de volgende vijf categorieën allereerst zelfstandig te zoeken en te benoemen:

1) Actoren: hoe ontwikkelen de rollen en relaties van de actoren zich?

2) Artefacten en technieken: welke artefacten spelen een rol in de activiteit?

3) Locaties en verplaatsing: hoe speelt de ruimte een rol in de activiteit?

4) Tijd en timing: hoe volgen handelingen elkaar op en zijn ze getimed?

5) Belangen, overtuigingen of idealen: welke belangen en idealen zijn verbonden aan de activiteit?

Op basis van de inventarisatie van de verschillende onderdelen uit de categorieën kan vervolgens gekeken worden hoe deze met elkaar samenhangen en eenheid vormen in een activiteit of ritueel. 


\subsection{DE DRAAI NAAR HET SACRALE: INZICHTEN VOOR ONDERZOEK, INNOVATIE, RELIGIE EN DEBAT}

\subsubsection{THE SACRED TURN}

Een technologische cultuur is ook een religieuze cultuur. Dat is enerzijds geen opmerkelijk conclusie, iedere cultuur is immers religieus. Waar culturen in verschillen is de manier waarop ze het sacrale vormgeven. Anderzijds geeft het inzicht dat een technologische cultuur ook een religieuze cultuur is, wel een nieuwe blik op de technologische cultuur. De technologische cultuur wordt immers in de regel als een seculiere cultuur beschouwd: ze zou geen religieuze grondmotieven of sacrale kern hebben. Die beschouwing blijkt gemankeerd. Ook in een technologische cultuur speelt het sacrale een centrale rol en is het sacrale onlosmakelijk verweven met geloof, rituelen en gemeenschappen.

Religies spelen een onmiskenbare rol in de technologische cultuur. In de Nederlandse technologische cultuur zijn vrijwel alle wereldgodsdiensten en vele in omvang kleinere religies aanwezig en actief. Dergelijke expliciete religies worden echter in de technologische cultuur niet als fundament voor de cultuur gezien. Ze worden gezien als iets dat gelovigen op de cultuur leggen in plaats van dat religies een gemeenschappelijk fundament vormen. Het complexe debat over religie in het publiek domein vertrekt vaak vanuit de positie dat religie een persoonlijke zaak is, die zich daarom in de privé-omgeving zou kunnen en moeten afspelen. ${ }^{442}$ Dat de technologische cultuur echter zelf een religieuze basis heeft, blijft daardoor impliciet. In deze studie van het sacrale is het religieuze karakter van de technologische cultuur geëxpliciteerd.

Lange tijd zijn de ontwikkeling van wetenschap en technologie vanuit de inhoud bestudeerd. Het zouden autonome ontwikkelingen zijn, die primair vorm kregen door rationele overwegingen, onderzoek en ontdekkingen. De wetenschap ontdekt de waarheid en op basis daarvan werden werkende technologieën ontworpen. De zogenaamde social turn in het wetenschaps- en technologieonderzoek verlegde de aandacht naar de verwevenheid van wetenschappelijke en technologische ontwikkelingen met maatschappelijke ontwikkelingen ${ }^{443}$ Daarin werd zichtbaar dat wetenschap en technologie geen autonome factoren zijn, maar dat 
hun dynamiek alleen te begrijpen is als ze in hun context bestudeerd worden. Bijker spreekt dan ook niet meer van ontwikkeling maar van socio-technische verandering. ${ }^{444}$ Met de social turn kwamen de sociale, politieke en economische aspecten in beeld van het techniekonderzoek. De religieuze en sacrale kant van socio-technische ontwikkelingen bleven echter nog onderbelicht in het denken over en onderzoeken van technologische ontwikkeling. Deze studie is een eerste aanzet voor een sacred turn in het technologieonderzoek. Ze toont het belang aan van religie in een technologische cultuur en de waarde van aandacht voor het sacrale in het onderzoek naar de dynamiek van socio-technische verandering. Hieronder verken ik de betekenis daarvan voor de samenleving en het onderzoek naar technologie en religie in de technologische cultuur vanuit verschillende vakgebieden.

\subsubsection{ONDERZOEK}

\section{Technologieonderzoek}

Met aandacht voor religie en de introductie van het sacrale opent zich een nieuwe blik en een nieuw onderzoeksveld binnen het technologieonderzoek. Niet alleen de inhoudelijke ontwikkeling of technologische vooruitgang, noch slechts de sociale machten en krachten, maar ook de inspiratie voor innovatie en stabilisatie worden object van onderzoek. De sacrale vorm is daarbij de eenheid van analyse. Aandacht voor de sacrale vorm sluit oog voor inhoudelijke en sociale aspecten van de socio-technische ontwikkeling allerminst uit. Veel meer biedt het sacrale een kader om dergelijke aspecten te integreren en van de delen een geheel te maken. Daarnaast geeft ze een dieper inzicht in de richting van de ontwikkeling. De rol van kennis en ervaring, machten en krachten in de vormgeving van technologie en richting van socio-technische ontwikkeling is onmiskenbaar maar wordt tegelijkertijd gezien als een contingent en ongericht proces. Met het sacrale wordt inzicht verkregen in de stabiliteit en richting van verandering. Tegelijkertijd is het sacrale geen externe, laat staan autonome verklaring van buiten de praktijk, het sacrale zelf is een resultaat van de praktijk en cultuur waarin ze opereert. Daarmee is het sacrale een waardevolle toevoeging aan het repertoire van het wetenschaps- en technologieonderzoek. Zonder het sacrale zijn de richting van socio-technische verandering en stabiliteit niet goed te begrijpen. 


\section{Religiewetenschappen en theologie}

Onderzoek naar het sacrale in de technologische cultuur is niet alleen relevant voor het technologieonderzoek, maar ook voor de religiewetenschappen. In het verleden is er al onderzoek gedaan naar de rol van religie in vele andere maatschappelijke domeinen, zoals bijvoorbeeld de economie. 445 De technologische cultuur biedt in aanvulling daarop mooie casuïstiek voor onderzoek naar seculiere praktijken en impliciete religie. ${ }^{446}$ Het kan daarbij interessant zijn om ook te kijken naar de rol van expliciete religies en hun interacties met de sacrale vormen van de technologische cultuur. Hoe geven expliciete religies en de technologische cultuur elkaar vorm, hoe botsen ze, hoe boetseren ze elkaar en trekken ze samen op?

In dit onderzoek staat een socio-technische ontwikkeling, namelijk die van PAZIO centraal. Daarmee komt de bijdrage van religie aan de technologische ontwikkeling voor het voetlicht. Interessant is dat met PAZIO zich zowel een werkende technologie als een impliciete religieuze praktijk ontwikkelen en dat beide nauw verweven zijn. De technologische ontwikkeling krijgt richting door een religieuze inspiratie voor innovatie, maar omgekeerd wordt in de studie ook zichtbaar dat er een religieuze ontwikkeling plaatsvindt met de technologische ontwikkeling. Die religieuze ontwikkeling in samenhang met de ontwikkeling van de technologie vraagt nader onderzoek. Op welke manieren geven socio-technische ontwikkelingen vorm aan de impliciete sacrale vormen van de technologische cultuur en hoe ontwikkelen expliciete religieuze tradities zich onder invloed van technologische ontwikkelingen? Het vertrekpunt zou voor dergelijke studies niet in een in technologie gefundeerde probe, zoals PAZIO, moeten zijn, maar een meer religieuze probe. Interessant in dat kader zijn bijvoorbeeld migrantenkerken. Migrantenkerken vormen de verbinding tussen het oude geloof van thuis en een nog te ontwikkelen versie van hun religie in Nederland. ${ }^{447}$ Daar is dus eveneens sprake van spanning tussen de noodzaak van innovatie en de behoefte aan behoud van orde en in die beweging speelt technologie onmiskenbaar een rol. Social media kunnen voor verbinding met de kerk in het land van herkomst zorgen en voor verbinding tussen mensen die buiten de wijk of stad wonen. Hoe zou de sacrale vorm van bijvoorbeeld migranten kerken in Rotterdam ${ }^{448}$ meebewegen en veranderen onder invloed van social media en technologieën als beamers, camera's en ontwikkelende 
muziekinstallaties en instrumenten? Wat betekent dat voor de rituelen, de gemeenschap en het geloof van een jonge kerk in een nieuw land? 449

Als we de technologische cultuur als religieus erkennen, ontstaat ook ruimte om onderzoek te doen naar de theologie van de technologische cultuur. Theologie doet onderzoek naar de bronnen van een geloof en ontwikkelt systematische analyse van het geloof (systematische theologie) en de geloofspraktijk (praktische theologie met daarin zaken als missiologie en liturgiek). Hoe ziet het impliciete geloof eruit? Hoe systematisch of heterogeen is dat samengesteld? Welke vooronderstellingen, redeneringen en verwachtingen zijn er? Hoe uiten die zich in het handelen en in de vorming van gemeenschappen en de organisatie daarvan? Een theologisch perspectief kan het inzicht in de sacrale vormen van de technologische cultuur verdiepen en versterken.

Binnen de systematische theologie is aandacht voor moraaltheologie of ethiek bijzonder interessant. Anders dan voor religie is in de technologische cultuur volop belangstelling voor ethiek. Technologieethiek is een gerespecteerde en gewaardeerde discipline zowel binnen als buiten de academie. ${ }^{450}$ Deze bezinning op goed en kwaad is in de technologische cultuur een vakgebied op zich, dat zich uiteraard laat informeren door andere vakgebieden en voortbouwt op eerdere inzichten en argumentaties. ${ }^{451}$ Vanuit theologisch perspectief is het interessant de ethiek te plaatsen in een context van systematische theologie van de technologische cultuur met daarbij aandacht voor bijvoorbeeld eschatologie, apologetiek en missiologie. Zo kan een ethiek van de technologische cultuur ontwikkeld worden, die verder gaat dan de ethische vragen rond een technologie of technologische ontwikkeling.

\subsubsection{TECHNOLOGIEONTWIKKELING EN INNOVATIE}

Technologie is gematerialiseerde religie. In technologie zitten idealen ingebakken of geprogrammeerd. Ze is het resultaat van een technische onderneming in een sociaal krachtenveld rond een sacrale vorm. Dat inzicht geeft nieuwe aanknopingspunten voor het ontwikkelen

\footnotetext{
448 Well, 'Zien en gezien worden. Diaconale presentie en diaconale actie door drie interculturele kerken in de Tarwewijk op Rotterdam-Zuid.'

$449 \mathrm{Er}$ is hier een interessante parallel te leggen met de reformatie waarin zich ook op basis van een gevestigde kerk een jonge kerk ontwikkelde hand in hand met de boekdrukkunst.

450 Het 4TU programma Ethics and technology is een illustratie van het belang dat binnen de academie en via haar partners ook daarbuiten aan technologie-ethiek gehecht wordt. Centre for Ethics and Technology, '4TU.Ethics Centre for Ethics and Technology'. 
en begeleiden van innovaties. Inspiratie voor innovatie wordt dan een belangrijk gegeven om de drijvende kracht achter de ontwikkeling te begrijpen. Die inspiratie maakt achteraf begrijpelijk waarom mensen samenwerken of niet, waarom technieken, businessmodellen, coalities de vorm krijgen die ze krijgen. Vooraf of in het innovatieproces zelf kan expliciteren van de veelal impliciete inspiratie de oorsprong, doel en zin van het proces bespreekbaar maken. De sacrale basis van de ontwikkeling wordt daarmee ook een actief onderdeel in de ontwikkeling.

Het sacrale vormt de basis die met de technologie ontstaat. Monitoring van de co-constructie van het sacrale en de technologie geeft handvatten om te begrijpen of en waarom relevante sociale groepen of individuele actoren betrokken en gemotiveerd zijn en hoe ze dat vertalen in de praktijk. Monitoring van en aandacht voor die basis draagt bij aan geïnspireerde ontwikkelingen en de vorming van stabiele techno-sacrale vormen.

Het sacrale biedt een nieuw aanknopingspunt om socio-technische ontwikkeling te monitoren, maar ook om nieuwe handelingsperspectieven te ontwikkelen. Het biedt de mogelijkheid om expliciet waardevolle motivatie en inhoud te ontwikkelen, om samenwerking te optimaliseren en om routines te ontplooien binnen de samenwerking en voor de socio-technische praktijk.

\subsubsection{RELIGIE}

Wat betekent het om expliciet religieus te zijn in de impliciet religieuze technologische cultuur? Impliciete en expliciete religies sluiten elkaar niet uit. De civil religion in de Verenigde Staten gaat al decennialang vanzelfsprekend samen met het christendom, de religies van native americans en andere religieuze tradities ter plekke. In de sacrale technologische cultuur zijn andere religieuze tradities ook vanzelfsprekend aanwezig. Dat betekent allerminst dat ze naadloos in elkaar overlopen of probleemloos samengaan. Het betekent wel dat ze in constante dynamiek met en naast elkaar bestaan. Het expliciet maken van het sacrale in de technologische cultuur maakt het mogelijk die vanzelfsprekendheden te onderzoeken. Hoe ben je hindoe, christen of moslim in een technologische cultuur, of atheïst of humanist? Dat is niet alleen een mogelijke wetenschappelijke onderzoeksvraag maar ook een praktische vraag voor geloofsgemeenschappen. Zij beantwoorden die vraag iedere dag in de praktijk. Het inzicht dat de technologische cultuur in zichzelf een religieuze cultuur is, geeft geloofsgemeenschappen een nieuw kader om deze vraag te doordenken en te beantwoorden in de praktijk. Hoe verhoudt onze religieuze traditie zich tot het sacrale in de technologische cultuur? 


\subsubsection{MAATSCHAPPELIJK DEBAT}

Technologische ontwikkelingen kunnen een maatschappelijk of moreel disruptief karakter hebben. Zo is bijvoorbeeld de seksuele revolutie onlosmakelijk verweven met de ontwikkeling van de anticonceptiepil ${ }^{452}$ en zijn de huidige duurzaamheidsvraagstukken niet los te zien van modernisering en industrialisatie. ${ }^{453}$ In kerken, moskeeën en andere religieuze gemeenschappen wordt regelmatig nagedacht en gedebatteerd over dergelijke ontwikkelingen en opkomende technologieën en duurzaamheidsvraagstukken. Omgekeerd spelen dergelijke gemeenschappen niet vanzelfsprekend ook een rol in maatschappelijke debatten over technologie en samenleving. ${ }^{454}$ Er is zowel vanuit de religieuze gemeenschappen als in de technologische cultuur een zeker ongemak om in het publiek debat vanuit een religieus perspectief te reflecteren op technologische ontwikkelingen. Het idee dat geloof een privéaangelegenheid is, die achter de voordeur hoort te blijven en niet in het publieke domein thuishoort, lijkt daarbij een rol te spelen. Inhoudelijk is dat een gemiste kans, zoals de serie het Theologisch elftal in het dagblad Trouw bijvoorbeeld laat zien. Daarin worden actuele maatschappelijke kwesties vanuit een religieus perspectief door theologen vanuit verschillende denominaties op originele en waardevolle wijze besproken en becommentarieerd. ${ }^{455}$

In debatten over socio-technische ontwikkelingen ${ }^{456}$ komt het religieus perspectief weinig tot niet aan bod. Het blijkt ook niet eenvoudig om tot een goede uitwisseling te komen. Naar aanleiding van het eerste gekloonde zoogdier, schaap Dolly, organiseerde het Rathenau Instituut rond de millenniumwissel enkele debatten over de technologie van het kloneren. Een van die debatbijeenkomsten ging over levensbeschouwing en kloneren. ${ }^{457}$ In die debatbijeenkomst gingen zes vertegenwoordigers van religieuze stromingen met elkaar in gesprek. De religieuze perspectieven werden als het ware op de technologische ontwikkeling gelegd. ${ }^{458}$ De religieuze kant achter de ontwikkeling zelf,

\footnotetext{
452 NTR, 'De seksuele moraal voor en na de pil'.

453 Schot, Techniek in Nederland in de twintigste eeuw.

454 Een uitzondering die de regel bevestigd is dat met name christelijke theologen in hun rol als ethicus nog wel aanschuiven bij medische-ethische kwesties. Zo is bijvoorbeeld prof.dr. Theo Boer, hoogleraar Ethiek van de Gezondheidszorg aan de Protestantse Theologische Universiteit, lid van de Gezondheidsraad.

455 Bijvoorbeeld over ruimtevaart: Mulder, 'Moeten we wel naar mars?'

456 Zoals bijvoorbeeld georganiseerd door het Rathenau instituut, De Balie of Pakhuis De Zwijger.

457 Biesboer, Klonen ter discussie.
}

458 Zie de analyse van het debat in Swierstra, Kloneren in de polder het maatschappelijk debat over kloneren in Nederland, februari 1997 - oktober 1999. 
de waarden en grondmotieven werden echter niet besproken. Dat was toentertijd niet verwonderlijk, de verwevenheden tussen technologie en religie zoals hier besproken, waren toen een nog onbekend terrein. De sacred turn in het technologieonderzoek geeft wel een perspectief om deze verwevenheid te onderzoek en de impliciete religie en sacrale vorm van een technologische ontwikkeling als kloneren in het maatschappelijk debat te agenderen. Dat zou het debat verrijken met idealen en overtuigingen, ambities en gewoonten, rituelen en tradities die eerder impliciet bleven.

\subsection{HET SACRALE EXPERIMENT}

De seculiere technologische cultuur is een religieuze cultuur, zo is de conclusie van dit onderzoek. De technologische cultuur heeft een eigen ongekende sacraliteit. Wat nu te doen met dat inzicht en potentieel? In 2015 publiceerde Hans Boutellier zijn boek met de titel Het seculiere experiment - hoe we van God los gingen leven. ${ }^{459}$ Naast een schijnbaar besluit tot secularisering in de jaren zestig, geeft hij een tweede reden om van een experiment te spreken. Hij citeert de politicoloog Mark Lilla die over de secularisering schrijft:

'Time and again we must remind ourselves that we are living an experiment, that we are exceptions. We have little reason to expect other civilisations to follow our unusual path.' ${ }^{460}$

Voor Boutellier is het seculiere experiment een min of meer bewuste poging van moderne westerse samenlevingen om los van God samen te leven. Dat experiment is mislukt noch geslaagd. De samenleving is allerminst uit elkaar gevallen en heeft een hoge mate van welvaart bereikt. Kortom: ja, we kunnen van God los samenleven. Tegelijkertijd is duidelijk geworden dat het niet te verwachten is dat dit experiment structureel zal worden en dat we allemaal en wereldwijd los van God zullen gaan leven, zoals op basis van de seculariseringthese werd verwacht. Wat Boutellier betreft verdient het seculiere experiment een vervolg: 'het komt er vooral op aan elkaar te bevragen wat voor de ander van waarde is.' 
Dat vragen naar wat van waarde is, is een vraag naar de gedeelde hoop en het gedeelde geloof. Maar ook een vraag naar de handelingen die we waardevol vinden en de sociale verbanden waarin we waarde ontsluiten of creëren. Het is een vraag naar het sacrale van de technologische cultuur. Op die vraag is in onze veranderlijke wereld geen eenduidig definitief antwoord te geven. Tegelijkertijd zijn er waardevolle tradities met een robuuste sacrale kern die stevigheid en richting kunnen geven bij het zoeken naar antwoorden, waar we ons aan vast kunnen houden en van los kunnen rukken, die inspireren en integreren. Meer nog dan de wetenschappelijke en technologische experimenten, is het sacrale experiment een van de spannendste experimenten in de technologische cultuur. 



\section{SAMENVATTING}

\section{SUMMARY}

\section{TIJDLIJN VAN DE ONTWIKKELING VAN PAZIO}





\section{SAMENVATTING}

In de wereld van vandaag spelen zowel technologie als religie een belangrijke rol. Toch worden ze niet vaak in één adem genoemd. Hebben ze desondanks iets met elkaar te maken? Zijn er interacties tussen technologie en religie? Wat is de rol van religie in onze hedendaagse technologische cultuur? Dat zijn de vragen waarop ik in dit proefschrift een antwoord zoek.

Het wetenschaps- en technologieonderzoek heeft laten zien dat technologische ontwikkelingen onlosmakelijk verweven zijn met sociale en culturele ontwikkelingen. Er wordt daarom gesproken van socio-technische ontwikkelingen. Het religieonderzoek heeft op haar beurt laten zien dat mensen vormgeven aan religie door geloof, rituelen en het vormen van morele gemeenschappen. Vanuit het idee dat elke praktijk gebaseerd is op religieuze grondmotieven, onderzoek ik de rol van geloof, rituelen en morele gemeenschappen in socio-technische ontwikkelingen.

In het denken over technologische ontwikkelingen is nauwelijks aandacht voor de rol van religie geweest. De eerste oorzaak daarvoor is gelegen in de manier waarop tegen technologie en religie aangekeken wordt. Ze worden vaak tegenover elkaar geplaatst als elkaar uitsluitende fenomenen: technologie zou rationeel en vernieuwend zijn en religie zou juist spiritueel en behoudend zijn. Een tweede oorzaak is gelegen in het denken in termen van secularisatie en vooruitgang. Op basis van de seculariseringstheorie wordt vaak verondersteld dat religie een verdwijnend fenomeen is, terwijl wetenschap en technologie juist onze toekomst gaan bepalen. Vanuit die denkwijze ligt het niet voor de hand om aandacht te besteden aan de rol van religie in technologische ontwikkelingen. De secularisatietheorie is echter academisch allerminst onomstreden. In het religieonderzoek wordt betoogd dat er niet zozeer sprake is van secularisatie, maar veel meer van een transformatie van religie: religie verdwijnt niet met modernisering, maar verandert mee met maatschappelijke ontwikkelingen.

Technologie en religie mogen op het eerste gezicht een vreemde combinatie vormen, tegelijkertijd blijken ze in allerlei ontwikkelingen en culturen nauw verbonden, zoals we zien in de industriële revolutie die plaats vond in een religieus Europa of in de Japanse cultuur die zowel hoogtechnologisch als diepreligieus is. In de huidige westerse samenlevingen heeft technologie zich ontwikkeld tot meer dan een instrument, 
ze is uitgegroeid tot een bepalende factor in onze manier van leven en denken. We leven in een technologische cultuur. In vrijwel alle culturen wordt de omgang met vragen over het leven en samenleven bepaald door de religieuze achtergrond van de betreffende cultuur. Dat roept de vraag op of er ook een rol voor religie is in de technologische cultuur en zo ja, wat die rol dan inhoudt.

Om die vraag te beantwoorden neem ik de ontwikkeling van het gezondheidsportaal PAZIO als een monster, probe, van de technologische cultuur. PAZIO werd ontwikkeld door een consortium van onder meer het Universitair Medisch Centrum Utrecht, de Leidsche Rijn Julius Gezondheidscentra en VitaValley. In de periode 2006-2012 werd allereerst een idee voor PAZIO, projectplannen en het consortium ontwikkeld; vervolgens ging het consortium de wereld in om financiële en morele steun te verkrijgen, waarna PAZIO bij Leidsche Rijn Julius Gezondheidscentra geïmplementeerd werd.

Ik onderzoek de PAZIO-probe op antropologische wijze. Van 2010 tot halverwege 2012 werkte ik als projectmedewerker mee aan de ontwikkeling van PAZIO, deed participerend observaties en archiefonderzoek.

\section{THEORIE OVER RELIGIE EN TECHNOLOGIE}

De historicus Noble laat zien dat technologie en religie in de westerse cultuur nauw verweven zijn. Technologie werd de afgelopen eeuwen steeds opnieuw ingezet om door religie ingegeven doelen te realiseren. Noble is ongelukkig met die door religie gerichte inzet van technologie en voert een pleidooi om te streven naar een van religie gezuiverde, seculiere technologische cultuur. De filosofen Dooyeweerd en Szerszynski hebben weinig fiducie in dat ideaal van Noble. Meer nog dat ze er bezwaar tegen zouden hebben, zien ze het als een onmogelijkheid. Zij laten zien dat religie door de eeuwen heen weliswaar verandert, maar niet verdwijnt. Szerszynski beschouwt het idee van de verlichte seculiere cultuur dan ook eerder als een mythisch scheppingsverhaal van de moderne samenleving dan als een wetenschappelijke theorie. Dooyeweerd en Szerszynski laten zien dat elke cultuur respectievelijk religieuze grondmotieven dan wel een sacrale orde kent. Daarmee bieden ze een mooi vertrekpunt voor het onderzoek naar de rol van religie in een technologische cultuur.

Om het onderzoek naar de rol van religie in een technologische cultuur vorm te geven worden drie theoretische benaderingen geïntroduceerd: het Triple I Model (TIM); Social Construction of Technology (SCOT) en Durkheims benadering van het sacrale.

Het TIM komt voort uit de traditie van de christelijke wijsbegeerte en is een middel om (professionele) praktijken te analyseren, dan wel te 
ontwikkelen. Om een praktijk te doorgronden wordt in het TIM aandacht gevraagd voor drie I's: de Identiteit van een praktijk, de Interests van de actoren en de Idealen van de cultuur waarin de praktijk zich bevindt. TIM helpt om de aard, de ambities en de identiteit van een praktijk te doorgronden. Zo is de praktijk van de gezondheidszorg gericht en ingericht op het morele aspect van zorgen voor elkaar.

SCOT komt voort uit het wetenschaps- en technologieonderzoek en geeft een constructivistisch perspectief op de ontwikkeling van technologie. Dat betekent dat ze de werking van technologische artefacten niet als intrinsieke eigenschap van het artefact ziet, maar als resultaat van het socio-technische verandering. Dat een technologie werkt is daarmee niet langer de verklaring voor het succes van een technologie, het werken van een technologie moet juist verklaard worden. In het onderzoeken van socio-technische veranderingen vraagt SCOT aandacht voor de relevante sociale groepen, de betekenisflexibiliteit rond het artefact en hoe deze stabiliseert in een technologisch frame. Met SCOT wordt zichtbaar hoe technologieontwikkeling onlosmakelijk verweven is met sociaal-culturele verandering.

Het constructivistisch technologieonderzoek biedt in principe alle ruimte om naar de wisselwerkingen tussen technologie en religie te kijken. Die ruimte is echter nog nauwelijks benut. Durkheim, één van de grondleggers van de sociologie, biedt een benadering van religie die goed aansluit bij het constructivistisch technologieonderzoek. Durkheim betoogt dat religie bepaald wordt door het fundamentele onderscheid dat mensen maken tussen het sacrale en het profane. Het sacrale krijgt vorm in het geloof en de rituelen van een morele gemeenschap.

Durkheim spreekt over het sacrale in enkelvoud. Dat doet geen recht aan de variëteit en nuance die in een cultuur onder het sacrale verborgen gaan. Lynch stelt daarom voor om naast het sacrale te spreken van sacrale vormen, die naast elkaar kunnen bestaan en interacteren. Het idee van de sacrale vorm is goed bruikbaar voor onderzoek naar religieuze diversiteit in een technologische cultuur.

TIM, SCOT en Durkheims benadering bieden drie elkaar aanvullende handvatten om de rol van religie in de technologische cultuur te onderzoeken. In navolging van Durkheim worden in dit onderzoek achtereenvolgens de rol van geloof, rituelen en gemeenschapsvorming in de ontwikkeling van PAZIO onderzocht. 


\section{GELOOF, RITUELEN EN \\ GEMEENSCHAPSVORMING IN \\ ONTWIKKELING VAN PAZIO}

In 2006 wordt vanuit Mediportaal, een kleine onderneming van het UMCU, begonnen met het ontwikkelen van een gezondheidsportaal. In eerste instantie ligt de focus op de ontwikkeling van een overtuigend en aantrekkelijk plan voor het project. Aanvankelijk zijn er slechts enkele partijen geïnteresseerd in de ontwikkeling van een gezondheidsportaal en die interesse komt voort uit hun particuliere belangen. Via projectvoorstellen en subsidieaanvragen ontwikkelen de betrokken partijen gaandeweg een gedeeld geloofsverhaal vol idealen, verwachtingen en ambities voor een PAtiëntgeoriënteerde ZorgInformatieOmgeving: PAZIO. Dat culmineert in de voorlichtingsfilm tijdens de kick-off waarin PAZIO gepresenteerd wordt als een omnipotent portaal dat vele problemen in de zorg kan verhelpen: met PAZIO worden informatie- en communicatieproblemen opgelost, komt de patiënt centraal te staan en wordt de zorg beter en efficiënter.

De drijvende kracht achter PAZIO is een groot geloof in autonomie, gezondheid en efficiëntie, in combinatie met een groot geloof in het verlossend vermogen van technologie. PAZIO is promising technology. Onduidelijk blijft echter hoe PAZIO haar beloften wil gaan vervullen. Het geloof in PAZIO kent enkele intrinsieke spanningen. Zo gaat het streven naar autonomie voor de patiënt moeilijk samen met de beheersingsdrang die het streven naar evidence based werken in de gezondheidszorg met zich meebrengt. Dat alles neemt niet weg dat het geloof in autonomie, gezondheid en technologische innovatie buiten kijf staat. De kracht van dit geloof zit in haar vermogen om te inspireren en te verbinden en niet zozeer in haar consistente redenaties of de heldere praktische uitwerking.

De uitdaging voor het PAZIO-team is vervolgens om de beloften in de praktijk waar te maken. Daaraan wordt gewerkt door de implementatie van PAZIO bij de Leidsche Rijn Julius Gezondheidscentra. LRJG is partner in het PAZIO-consortium en deelt met PAZIO het geloof in technologie als het middel om hun idealen te realiseren. PAZIO en LRJG brengen in het implementatieproces desondanks ieder hun eigen sacrale vorm mee. In de sacrale vorm van PAZIO staat de autonomie van de patiënt centraal. LRJG daarentegen is gericht op het verlenen van goede zorg en zet daarom de behandelrelatie centraal en niet de autonomie van de patiënt. Bij de implementatie van PAZIO bij LRJG worden de verschillen in de sacrale vormen voelbaar en ontstaat spanning.

In het implementatieproces ligt de focus op de ontwikkeling van rituelen om PAZIO onderdeel te maken van de zorgpraktijk. Het technologieonderzoek heeft laten zien dat het in implementatieprocessen belangrijk 
is om routines te ontwikkelen. Dit onderzoek laat in aanvulling daarop zien dat de routines en hun ontwikkeling een oriëntatie op de sacrale vorm kennen en daarom beter te begrijpen zijn als rituelen.

De oriëntatie van rituelen op de sacrale vorm helpt om het verloop van het implementatieproces te begrijpen. Zo staan de zorgverleners van LRJG voor de keuze tussen de integratie van PAZIO met hun huisartsinformatiesysteem (HIS-integratie) of Portaal-integratie. Ze kiezen niet voor de HIS-integratie die hen veel werk zou besparen, maar voor de Portaal-integratie. Dat is optimaal voor de patiënten, maar belast de zorgverleners wel met extra werk. Deze keuze is goed te verklaren vanuit de sacrale vorm waarin de ontwikkeling van een goede (digitale) behandelrelatie centraal staat.

Rituelen krijgen in de praktijk vorm met profane middelen als tijd, geld, ruimte en mensen. Dergelijke middelen zijn schaars. De zorgverleners worstelen met de spanning tussen sacrale idealen en de profane praktijk. Hoeveel ruimte moeten en kunnen patiënten krijgen in de online rituelen, hoeveel vragen mag een patiënt stellen per eConsult, welke medische aandoeningen kunnen in een eConsult besproken worden, hoeveel tekstruimte geven we de patiënt zodat het eConsult voor de zorgverleners werkbaar blijft? In het beantwoorden van die vragen botsen sacrale idealen van de zorgverleners over de behandelrelatie op praktische bezwaren. De worstelingen van de zorgverleners zijn te begrijpen als we oog hebben voor de sacrale vorm waarin het verlenen van goede zorg centraal staat.

Opvallend is dat de sacrale vorm die in het project PAZIO ontstond, het centraal stellen van de patiënt, binnen de LRJG-praktijk niet of nauwelijks wordt uitgewerkt in rituelen. In de LRJG-praktijk zijn andere sacrale idealen leidend: men gelooft primair in het verlenen van goede zorg door het inzetten van wetenschappelijke inzichten en technologische mogelijkheden voor de opbouw van een goede behandelrelatie.

Naast geloof en rituelen wordt in de PAZIO-probe ook het derde element van religie uit Durkheims benadering zichtbaar: de morele gemeenschap. De ontwikkeling van de morele gemeenschap en de sacrale vorm trekken samen op. In het onderzoek naar de ontwikkeling van de morele gemeenschap en sacrale vorm in de PAZIO-probe worden drie perioden zichtbaar.

In de eerste periode van de PAZIO-ontwikkeling wordt vertrokken vanuit de particuliere perspectieven en belangen van de betrokken partijen. Vervolgens ontwikkelt zich een rudimentair gedeeld geloof: in de plannen worden de gedeelde ambities en idealen geformuleerd. Er vormt zich een projectorganisatie waarin alle partners een rol krijgen toebedeeld. Daarmee ontstaat vertrouwen in elkaar en een eerste morele gemeenschap rond het project. Dat wordt bekrachtigd in een convenant en in formele projectplannen. Het beoogde gezondheidsportaal krijgt met 
PAZIO een naam en een logo. Het zijn op dat moment de iconen van de sacrale vorm, ze representeren het geloof en de gemeenschap.

In de tweede periode wordt vanuit PAZIO gezocht naar externe partners die PAZIO moreel en materieel willen steunen. Dat vraagt een uitwerking van het geloof in PAZIO, zodat dat ook aantrekkelijk is voor subsidieverleners en partners buiten het consortium. Er wordt een geloofsverhaal rond PAZIO geconstrueerd waarin verschillende problemen in de zorg gekoppeld worden aan de omnipotente oplossing PAZIO. In het narratief en in de morele gemeenschap rond PAZIO krijgt de patiënt een sacrale status toebedeeld: de patiënt staat centraal. Die sacrale status wordt verbeeld in de iconische patiënt mevrouw De Wolf, die naar een beetje vrijheid verlangt. De sacrale status maakt dat patiënt centraal staat in het geloof, maar ook dat ze verder geen rol toebedeeld krijgt in het ontwikkelproces van PAZIO. Het uitkristalliseren van het geloof gaat samen met een groeiende morele gemeenschap die PAZIO steunt. Het leidt ertoe dat PAZIO een Pieken in de Deltasubsidie van twee miljoen euro ontvangt.

In de derde periode is het uitdaging om PAZIO te laten werken in de praktijk. Er wordt een implementatiepilot gestart bij LRJG. PAZIO moet daar aansluiten op de zorgpraktijk van de zorgverleners, die een digitale behandelrelatie willen realiseren. In eerste instantie groeien LRJG en PAZIO uit elkaar, doordat de sacrale vormen van PAZIO en LRJG niet op elkaar aansluiten en er profane praktische problemen zijn rond het gebruik van PAZIO. Het LRJG-management en de zorgverleners hebben weinig vertrouwen in de meerwaarde van PAZIO. Met het gezamenlijk ontwikkelen van passende rituelen voor de digitale behandelrelatie ontstaat nieuw vertrouwen, een nieuwe morele gemeenschap rond PAZIO in de LRJG-praktijk en een gedragen sacrale vorm waarin een op goede zorg gericht digitale behandelrelatie richtinggevend is.

In de drie periodes in de PAZIO-ontwikkeling is een terugkerende dynamiek zichtbaar: op een fase van verandering en verscheidenheid volgt een fase van verbinding. Relevante sociale groepen ontwikkelen zich tot een morele gemeenschap. Die morele gemeenschap probeert op zijn beurt problemen op te lossen en haar idealen te verwezenlijken en schept daarbij ruimte voor nieuwe relevante sociale groepen om te participeren. De sacrale vorm zorgt met haar gedragen overtuigingen, idealen en rituelen voor richting in de ontwikkeling en verandert mee met de ontwikkeling. De sacrale vorm is de inspiratie voor innovatie die verandering in gang zet en de verbindende kracht die zorgt de stabilisering van een praktijk. 


\section{HET SACRALE IN EEN TECHNOLOGISCHE CULTUUR}

Het onderzoek leidt tot twee belangrijke inzichten en een theorie van het Sacrale in een Technologische Cultuur. Allereerst is er het inzicht dat ook een technologische cultuur een religieuze cultuur is. Die religieuze basis is echter niet eenvoudig te herkennen, omdat de religie van de technologische cultuur een impliciet en immanent karakter heeft.

Het tweede inzicht is dat de sacrale vorm richtinggevend is voor de socio-technische ontwikkelingen in de technologische cultuur. Met het sacrale wordt orde aangebracht, ontstaan idealen en krijgt de banale werkelijkheid betekenis. Daarmee ontstaan de twee grote krachten van religie: het streven naar behoud van de sacrale orde en het werken aan het sacrale ideaal. Het technologieonderzoek heeft laten zien dat socio-technische ontwikkelingen niet doelgericht zijn in de zin dat ze op een vooraf vastliggend technologisch resultaat aansturen. De sacrale benadering van Durkheim laat als aanvulling daarop zien hoe socio-technische veranderingen wél richting krijgen. Met hun overtuigingen, rituelen en idealen geven sacrale vormen richting aan socio-technische veranderingen. Een sacrale vorm is zowel een inspiratie voor innovatie als ook een bron voor integratie en stabilisatie van socio-technische praktijken. De sacrale vorm is daarbij een intrinsiek onderdeel van de veranderings- en stabiliseringsprocessen, ze ontwikkelt zich in de ontwikkeling.

Om de dynamiek rond het sacrale in socio-technische praktijken te begrijpen en bestuderen wordt op basis van de inzichten van dit onderzoek een theorie van het Sacrale in een Technologische Cultuur (STC) ontwikkeld. De STC beschrijft hoe de ontwikkeling van een sacrale vorm verweven is met verandering in en stabilisering van socio-technische praktijken.

De sacrale vorm is zowel een bron van inspiratie voor innovatie als het kristallisatiepunt voor integratie van socio-technische praktijken. Dat wordt zichtbaar in de ontwikkeling van sociale verbanden, narratieven en activiteiten.

In een stabiliseringsfase zien we dat sociale verbanden zich ontwikkelen van een diversiteit aan relevante sociale groepen tot een morele gemeenschap (zie fig. S.1a); dat narratieven met een onderlinge betekenisflexibiliteit uitkristalliseren tot een gedeeld geloof (zie fig. S.1b) en dat vanuit utilitaire activiteiten rituelen ontstaan (zie fig. S.1c). Gezamenlijk formeren geloof, rituelen en morele gemeenschap zich tot een sacrale vorm (zie fig. S1.d). 


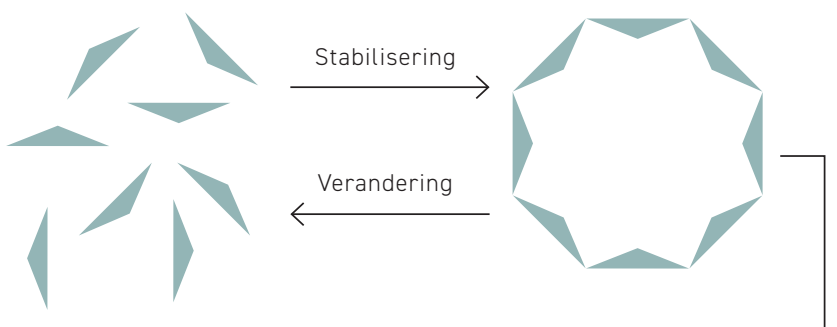

FIGUUR S.1a Narratief-sacrale dynamiek.

Betekenisflexibiliteit

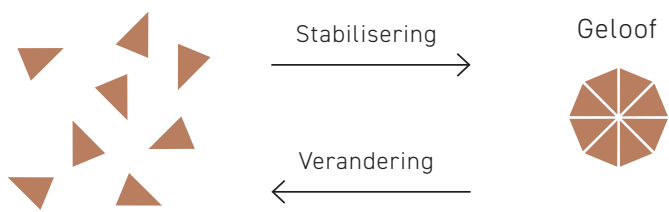

FIGUUR S.1b Narratief-sacrale dynamiek.

FIGUUR S.1d

Sacrale vorm

Ulitaire activiteiten

Rituelen
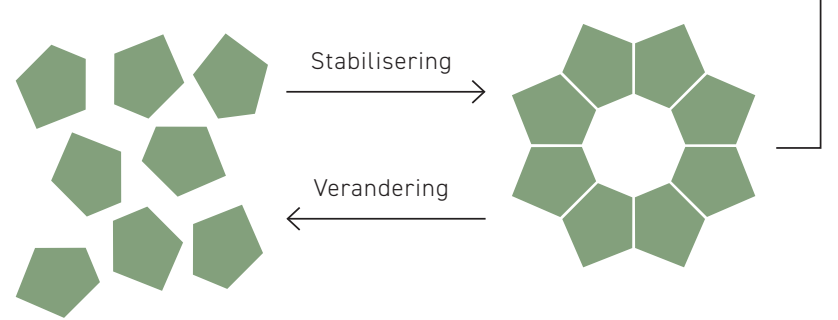

FIGUUR S.1c Activiteiten-sacrale dynamiek.

FIGUUR S. 1 Dynamiek en sacrale vorm. 
In de veranderfase biedt de stabiele sacrale vorm een gedeelde inspiratie voor innovatie en ontstaat daarmee juist weer ruimte voor nieuwe relevante sociale groepen, betekenisflexibiliteit en utilitaire activiteiten die moeten uitkristalliseren tot een nieuwe stabiele sacrale vorm en socio-technische praktijk.

De STC maakt het mogelijk om socio-technische dynamiek te analyseren aan de hand van de ontwikkelingen in narratieven, sociale verbanden en activiteiten in relatie tot zowel de stabilisering als de verandering van sacrale vormen (zie fig. S.2).

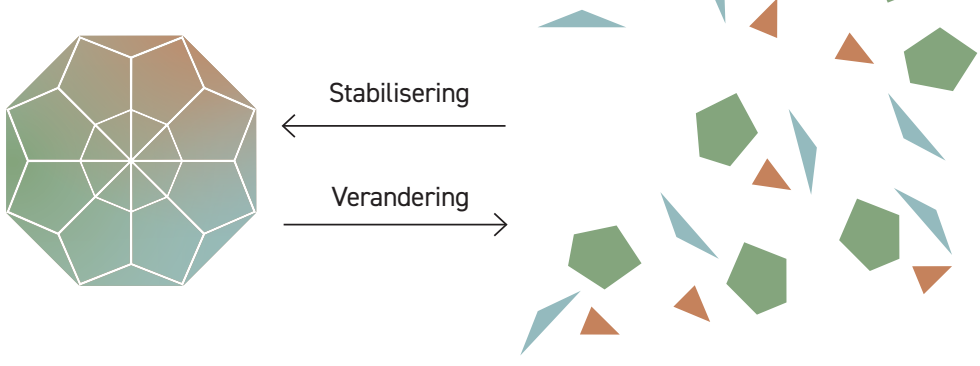

FIGUUR S.2 Theorie voor het Sacrale in een Technologische Cultuur (STC).

Deze studie geeft een aanzet voor een sacred turn in het technologieonderzoek. Met aandacht voor religie en de introductie van het sacrale opent zich een nieuwe blik en een nieuw onderzoeksveld. De sacrale vorm wordt een onderdeel van het onderzoek naar socio-technische veranderingen. Als we oog krijgen voor de religie van de technologische cultuur ontstaat ruimte om onderzoek te doen naar de theologie van de technologische cultuur. Daarnaast is de interactie tussen de sacrale vormen van expliciete en impliciete religies in de technologische cultuur relevant voor een samenleving waarin diversiteit een belangrijk maatschappelijk thema is. De sacred turn biedt ook nieuwe thema's voor praktijkgericht onderzoek. Zo wordt onderzoek naar handelingsperspectieven rond inspiratie van innovatie relevant: hoe kan het expliciteren en bespreekbaar maken van zin, idealen en rituelen innovatieprocessen richting geven en versterken? Hoe kunnen we in het maatschappelijk debat over technologische ontwikkelingen de impliciete en expliciete religieuze grondmotieven een plek geven en zo het debat verdiepen en verrijken? De sacrale vormen in de technologische cultuur daagt het onderzoek uit tot nieuwe wegen en nieuwe experimenten. 



\section{SUMMARY}

Technology and religion both play an important role in society. Hardly are they discussed together, though. Do technology and religion have anything in common? Are there any interactions between them? What is the role of religion in our current technological culture? These are the question to be answered in this thesis.

Science and Technology Studies (STS) have shown that technological developments are inseparable from social and cultural developments. That is why technological developments are often called socio-technical. Religious studies have demonstrated how people shape religion with the formation of beliefs, rituals and communities. Combining these two starting points, I shall study the role of beliefs, rituals and moral communities in shaping socio-technical change.

In the study of socio-technical developments hardly any attention is given to the role of religion. Technology and religion are considered opposites that are mutually exclusive: technology is seen as rational and innovative, while religion is deemed spiritual and conservative. A second reason for the limited attention to religion in technological developments results from considerations of secularisation and progress. The secularisation thesis posits that religion is vanishing while science and technology are determining the future. The secularisation thesis is not undisputed in academia, though. Religious studies have shown that rather than a process of secularisation, we witness a transformation of religion. Religion does not vanish with modernisation, but transforms along with societal change.

So, at first sight, technology and religion may be at odds, but a closer look reveals that they are intertwined in all kinds of developments and cultures. The industrial revolutions that took place in $19^{\text {th }}$-century Europe and in $20^{\text {th }}$-century Japan are telling examples. In today's Western societies, technology has become more than an instrument: technology has become a dominant factor in our way of living and thinking. We live in a technological culture. Since most cultures can be characterised by some religious background, this raises the question whether there is also a role for religion in a technological culture and if so, what that role could be. 
To address that question, I use the development of the health portal PAZIO as a probe to study the technological culture of The Netherlands. PAZIO was developed by a Dutch consortium of, amongst others, the University Medical Centre Utrecht (UMCU), the Leidsche Rijn Julius Health Centre (LRJG) and VitaValley (a network for health innovation). In 2006-2012, the initial idea of PAZIO, the project plans and a consortium were developed. Then the consortium gathered financial and policy support, developed PAZIO and implemented it at the Leidsche Rijn Julius Health Centre.

My research method is anthropological. From 2010 until mid 2012 I was employed to work on the development of PAZIO, and at the same time doing participant observations and document research.

\section{THEORIES ON RELIGION AND TECHNOLOGY}

The historian Noble has shown that technology and religion are closely intertwined in Western history. In the last centuries, technology was used repeatedly to realise religiously inspired aims. Noble is not in favour of such religiously-inspired technology development and argues in favour of a technological culture that steers clear of religion. Philosophers Dooyeweerd and Szerszynski question Noble's point of view-not because they don't agree with his analysis, but because they consider non-religious cultures impossible. They both demonstrate, in very different ways, that religion may radically transform through time but never disappears. Szerszynski considers the idea of an enlightened secular culture more as a myth that tells a story of the creation of a modern society than as an empirical finding. Dooyeweerd and Szerszynski show that every culture has, respectively, a basic belief or a sacral order. This provides my starting point for an analysis of the role of religion in a technological culture.

To study the role of religion in a technological culture, three theoretical approaches are used in this thesis: the Triple I Model (TIM); the Social Construction of Technology (SCOT) and Durkheim's theory of the sacred.

TIM stems from the tradition of Christian philosophy and provides a tool to analyse and develop professional practices. To analyse a practice, TIM focusses on three I's: the identity of the practice, the interests of the actors and the ideals of the culture that the practice is part of. TIM provides helpful insights into the nature, ambitions and identity of a practice. In this way, healthcare practices can be shown to be aimed at and guided by the moral imperative of caring for each other. 
SCOT is a research heuristic in STS and provides a constructivist perspective on technological development. So, the working of a

technological artefact is not seen as an intrinsic property of that artefact, but as the result of social interactions. The working of a technology does not offer an explanation of its success, but asks for explanation by tracing the social interactions around its use. SCOT approaches socio-technical change by studying relevant social groups, the interpretative flexibility of an artefact and the construction of artefacts within a technological frame. SCOT thus provides insight into the interwovenness of technological, social and cultural change.

In theory, constructivist technology studies could provide ample space for analysing the dynamics between technology and religion. This space however has hardly been explored. Durkheim, one of the founders of sociology, provides an analysis of religion which matches well with constructivist technology studies. Durkheim argues that religion is characterised by the fundamental distinction that humans make between the sacred and the profane. The sacred is shaped by beliefs, rituals and moral communities. Durkheim presents the sacred in singular form and ignores the cultural variety and nuances behind the sacred. Instead, Gordon Lynch promotes the idea of sacred forms in plural, which can co-exist and interact. The concept of sacred form proofs to be useful in the analysis of religious diversity in a technological culture.

\section{BELIEFS, RITUALS AND COMMUNITIES IN THE DEVELOPMENT OF THE HEALTH PORTAL PAZIO}

In 2006, the small company Mediportaal, which was associated with the UMCU, started with the development of a health portal. At first the focus is on the development of a sound and convincing plan for the project. Initially only a few parties are involved and their involvement is the result of varying individual interests. Via project proposals and requests for funding the parties gradually develop a common belief in PAZIO, filled with ideals, expectations and ambitions-a Patiëntgeorientëerde Zorg Informatie Omgeving (patient-oriented health information portal). This culminates in a short promotional film presented during the kick-off meeting where PAZIO is presented as an omnipotent portal with the ability to solve a variety of problems in healthcare: with PAZIO, information and communication problems will disappear, the patient will gain a central position in the care process and healthcare will increase in quality and efficiency. 
The main drive for PAZIO is a huge belief in autonomy, health and efficiency, combined with another huge belief in technology's ability to solve any kind of problems. PAZIO is promising technology. However, it is unclear how PAZIO will live up to these promises. The belief in PAZIO has several internal contradictions. Seeking autonomy for the patient is not easily combined with the aim of evidence-based medicine, which implicates rules and control. Which is not to suggest that the belief in autonomy, health and technology is not firm. The capacity of this belief can be traced back to the power to inspire and connect and not so much to some consistent logic or clear way of operating.

The next challenge for the PAZIO-team is to actually deliver on the promises. The implementation of the health portal PAZIO at the LRJG is a step towards that goal. LRJG is partner in the PAZIO-consortium and shares the believe in technology as a tool to realise ideals. In addition, PAZIO and LRJG also introduce their own sacred form into the implementation process. In the sacred form of PAZIO the autonomy of the patient is the focal point. LRJG's main aim is on delivering good care by focussing on the therapeutic relationship and to a lesser extent on the autonomy of the patient. With the implementation of PAZIO at LRJG, the differences between sacred forms become visible and tensions rise.

In the implementation process the development of rituals is the focal point-rituals that should help to integrate PAZIO into the care practice. Technology studies have shown that the development of routines is an important part of implementation processes. This study adds to this body of knowledge by showing that routines and their development are oriented by the sacred form and are therefore better understood as rituals.

The development of the implementation process can be understood by the orientation of the rituals towards the sacred form. The healthcare providers of LRJG have to choose between the integration of PAZIO in their primary care information system (HIS-integration) or the integration of the portal for patients (Portal-integration). They do not opt for HIS-integration, which would save them a substantial amount of work, but instead prefer the Portal-integration. This implies an extra effort on behalf of the healthcare providers, but promises an optimal online experience for their patients. This preference can be explained with the sacred form that guides the development and which is centered around the optimization of the (digital) therapeutic relationship. 
Rituals are shaped by profane means such as time, space, money and people, all of which are limited. Healthcare providers struggle with the tension between sacred ideals and the flaws of a profane practice. How much online space do patients need or deserve, how many questions can be asked by a patient in one eConsult, which medical conditions can be brought up in an eConsult, how do we balance the amount of text space for the patient in an eConsult with doability of the job for the healthcare provider? In answering such questions, the sacred ideals of the healthcare provider are challenged by practical concerns. The struggle of the healthcare providers with practical issues is to be understood in the context of the scared form in which providing good care has priority. Notably, the sacred form that was developing in the PAZIO-project-the autonomy of the patient-is hardly mirrored in rituals of the LRJGpractice. In the LRJG-practice, another sacred ideal is leading: the belief in providing good care by using scientific insights and technological solutions to build a good therapeutic relationship.

In addition to beliefs and rituals, the third element of Durkheim's approach of religion becomes visible: the moral community. The development of a moral community and the development of a sacred form happen together. In the PAZIO development of moral communities and sacred forms, three periods can be distinguished.

In the first period of the development of PAZIO, the actors start off with their own particular perspectives and interests. In the developed plans for PAZIO shared ambitions and ideals are formulated. On that basis, a shared but rudimentary belief is settled. A project organisation is set up in which all partners play a part. Trust is developed in both the project and the partners and a first moral community established. This is reaffirmed in the formal project plans and in the signing of a covenant. The envisaged health portal is given a logo and a name: PAZIO. At that very moment these are the icons for the sacred form; they represent the beliefs and the community.

In the second period of the development of PAZIO, a search begins for external partners for both moral and material support. In order to get there, the PAZIO-belief needs to become clear and attractive for funders and other partners outside the consortium. A narrative of belief is developed for PAZIO in which several problems in healthcare are connected to the omnipotent solution that PAZIO represents. In the 
narrative and moral community of PAZIO, the patient is given a sacred status: the central focus of care is the patient. That sacred status is represented in the image of the iconic patient Mrs. de Wolf, who longs for a little freedom. The sacred status has two effects on the patient: in the narrative of believe, the patient is placed at the centre of care, but in the practical development of PAZIO the patient does not play any significant role in the development of PAZIO. The crystallisation of the believe in PAZIO coincides with a growing moral community supporting PAZIO. This results in a two million euros grant for PAZIO.

In the third period of the development of PAZIO, the challenge is to get PAZIO operational in the healthcare practice. A pilot implementation is started by LRJG. PAZIO is to be connected to the healthcare practice so that healthcare professionals can realise digital therapeutic relationships with their patients. Initially PAZIO and LRJG grow apart, as the sacred forms of PAZIO and LRJG are too different and profane practical problems arise in the use of PAZIO. The LRJG-management and the healthcare providers have little faith in the added value of PAZIO. With a joint development of rituals for the digital therapeutic relationship, the faith in PAZIO and trust in each other are established again. A shared sacred form is built in which the digital therapeutic relationship for good care is the focal point.

In the three consecutive periods in the development of PAZIO a recurring dynamic can be seen: a phase of change and diversity is followed by a phase of connection and unity. Relevant social groups become a moral community with shared beliefs and rituals. This moral community then tries to realise ideals and solve problems. In doing so, the community creates space for new relevant groups to participate. The sacred form with shared convictions, ideals and rituals directs the development and changes with the development. The sacred form is at the same time an inspiration for innovation as a starter for change and a binding glue for stabilizing the practice. 


\section{THE SACRED IN A TECHNOLOGICAL CULTURE}

This study leads to two new insights and a theory of the Sacred in a Technological Culture. The first insight is that a technological culture is a religious culture. The religious aspect, however, is not easily recognised since religion of a technological culture has an implicit and immanent nature.

The second insight is that a sacred form is guiding the sociotechnical developments in a technological culture. With the sacred the mundane reality acquires meaning and order, and ideals are developed. Two strong forces of religion become visible: strive for perseverance of the sacred order and the aim to work on realisation of sacred ideals. Technology studies have shown that socio-technical developments are not goal-oriented in the sense that they are directed at a predetermined technological result. However, Durkheim's sacral approach shows that socio-technical changes do develop a direction. By means of beliefs, rituals and communities, sacred forms give direction to socio-technical change. A sacred form is both an inspiration for innovation and a source for integration and stability of socio-technical practices. The sacred form is an intrinsic part of these processes of change and stability. Sacred forms develop within the socio-technical developments.

Based on the insights in this study, a theory of the Sacred in a Technological Culture (STC) is proposed to understand and analyse the dynamics of the sacred in socio-technical practices. STC describes how the development of a sacred form is interwoven with change and stabilisation of socio-technical practices.

Central in STC are the dynamics of change and stabilization in sociotechnical practices. The processes are inseparable from developments of the related sacred form.

The sacred form is both source for inspiration for innovation and crystallization point for integration of socio-technical practices. This becomes visible in the development of the social relations, narratives and activities. In the stabilization phase, social relations are developed from a diversity of relevant social groups towards a moral community (see fig. S.1a); narratives with interpretative flexibility crystalize towards a shared belief (see fig. S.1b) and useful activities become rituals (see fig. S.1c). Together beliefs, rituals and moral community constitute a sacred form (see fig. S.1d). 

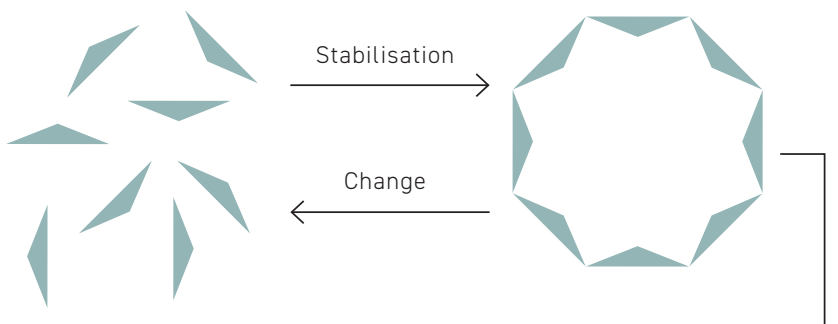

FIGURE S.1a Social-sacred dynamics.

Interpretative flexibility

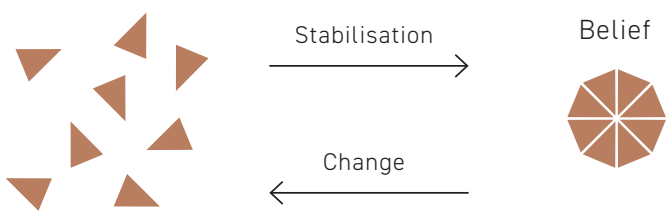

FIGURE S.1b Narratives-sacred dynamics.

FIGURE S.1d

Sacred form

Activities

Rituals
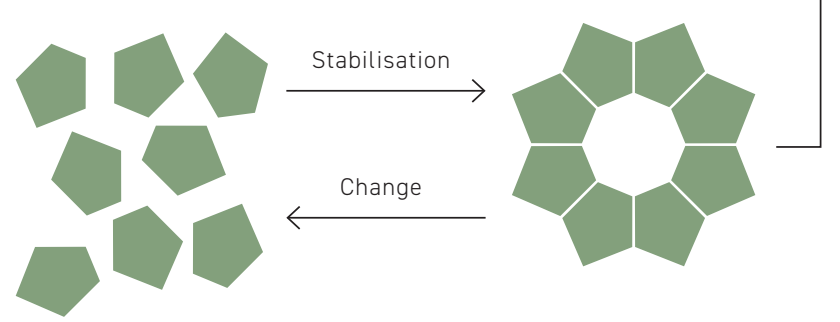

FIGURE S.1c Community-sacred dynamics.

FIGUUR S.1 Dynamics and sacred form. 
In the phase of change the stable sacred form provides a shared inspiration for innovation and as such space for new relevant social groups, interpretative flexibility and utilitarian activities which should crystalize again in a new stable sacred form and socio-technical practice (see fig. S.2). The STC enables an analysis of socio-technical dynamics in terms of narratives, social relations and activities related to both change and stabilization.

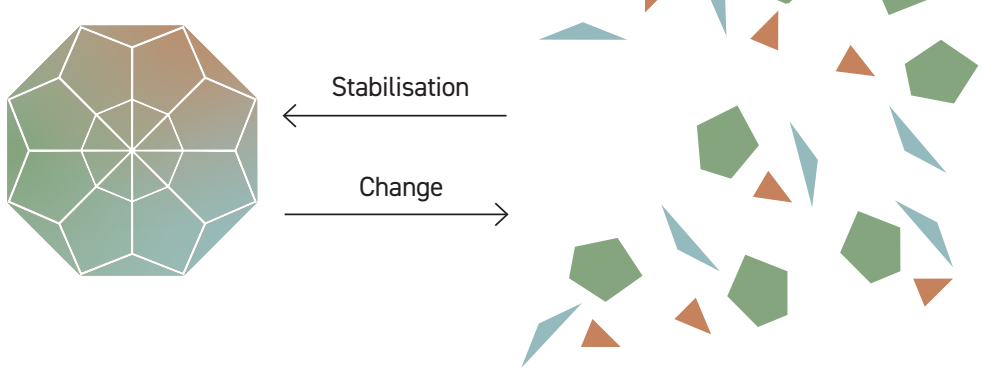

FIGURE S.2 Theory of the Sacred in a Technological Culture.

This study provides a starting point for a sacred turn in technology studies. By taking religion into account and by introducing the sacred, novel approaches and a new field of study open up. The sacred form becomes part of the study of socio-technical change. By paying attention to the religion of technological cultures, research into the theology of the technological culture becomes possible. Studying the interactions between the sacred forms of explicit and implicit religions in technological cultures has become especially urgent for societies in which diversity is an important theme. The sacred turn also introduces new opportunities for practice-oriented research. What are the dynamics of inspiration for innovation and which interventions are effective? How can the explication of beliefs, ideals and rituals guide and deepen innovation processes? How can the societal debates about technological developments be enriched with implicit and explicit religious beliefs? Sacred forms in a technological culture challenge current ways of research and require new experiments. 



\section{TIJDLIJN VAN DE ONTWIKKELING VAN PAZIO}

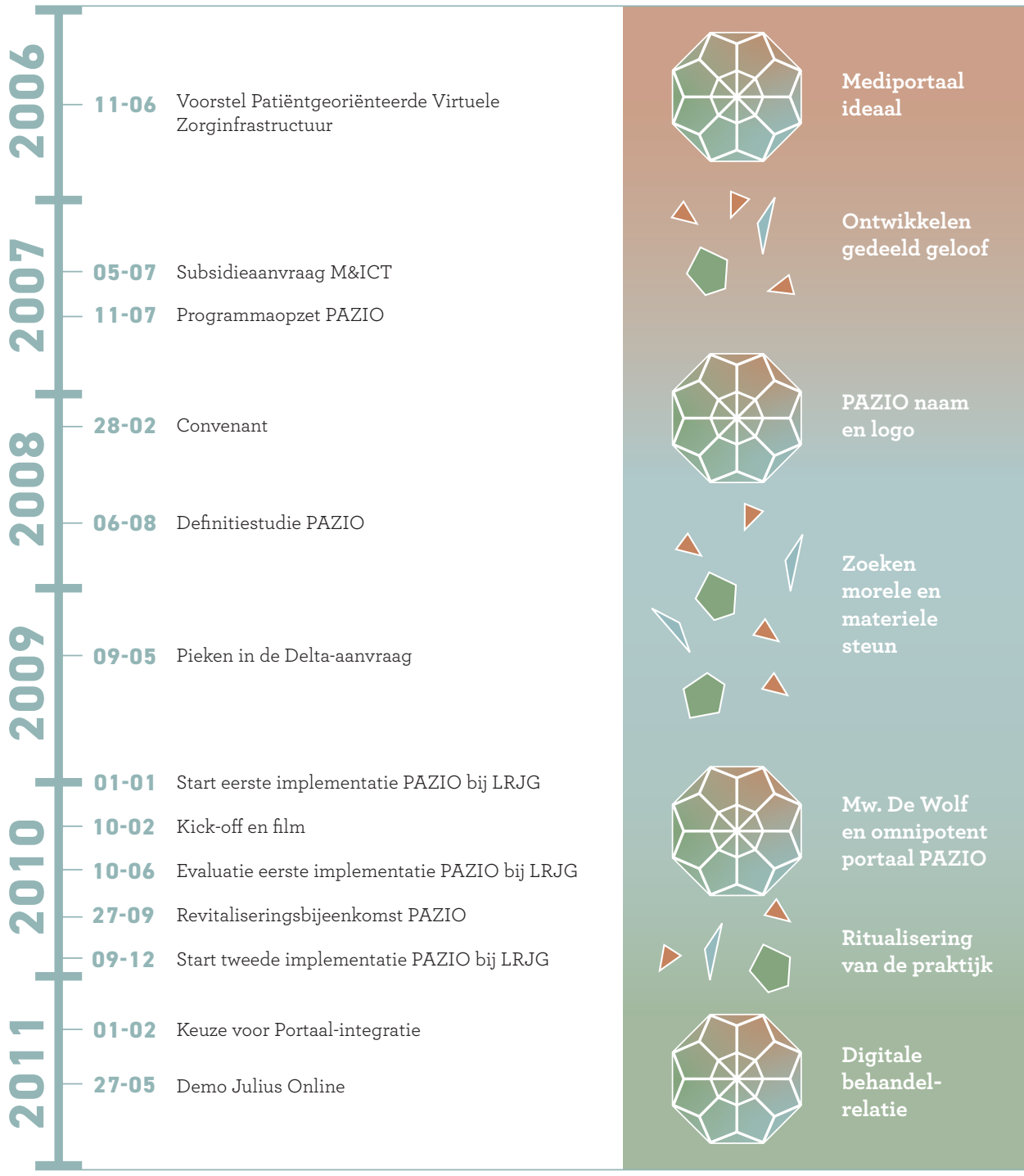





$$
\begin{array}{r}
\text { BIBLIOGRAFIE } \\
\text { EMPIRISCH } \\
\text { MATERIAAL PAZIO } \\
\text { AFKORTINGEN } \\
\text { FIGUREN EN } \\
\text { TABELLEN }
\end{array}
$$





\section{BIBLIOGRAFIE}

Achterhuis, Hans. De erfenis van de utopie. Amsterdam: Ambo, 1998.

Alexander, Jeffrey C. 'The computer as sacred and profane'.

In The New American Cultural Sociology, onder redactie van Philip Smith, 29-46. Cambridge Cultural Social Studies. Cambridge: Cambridge University Press, 1998.

-- . The meanings of social life: a cultural sociology.

Oxford University Press, 2003.

Alexander, Jeffrey C., Bernhard Giesen, en Jason L. Mast.

'Performing the sacred: a Durkheimian perspective on the performative turn in the social sciences'. In Social performance: symbolic action, cultural pragmatics, and ritual, 325-67. Cambridge cultural social studies. New York [N.Y.] ; Cambridge University Press, 2006.

Stichting Alpe d'HuZes. 'Alpe d'HuZes'. Geraadpleegd 11 september 2020. https://www.opgevenisgeenoptie.nl/about-alpe-dhuzes/ wat-is-alpe-dhuzes.

Asad, Talal. Formations of the secular: Christianity, Islam, modernity. Cultural memory in the present. Stanford, Calif: Stanford University Press, 2003.

Bellah, Robert N. 'Civil religion in America'. Daedalus 96, nr. 1 (1967): $1-21$.

-- ' 'Religion and legitimation in the American Republic'. Society 15, nr. 4 (1978): 16-23.

Bellah, Robert N., en Phillip E. Hammond. Varieties of civil religion. S.l.: Wipf and Stock, 2013.

Beteor. 'Henk van der Tas'. Geraadpleegd 8 januari 2021. https://beteor.nl/medewerker/henk-van-der-tas/. 
Biesboer, Frank. Klonen ter discussie: verslag van vijf debatbijeenkomsten. Den Haag: Rathenau instituut, 2000.

Bijker, Wiebe E. Democratisering van de technologische cultuur (Inaugurele rede). Maastricht: Rijksuniversiteit Limburg, 1995.

-- - 'How is technology made? That is the question!' Cambridge Journal of Economics 34, nr. 1 (2010): 63-76.

-- Of bicycles, bakelites, and bulbs: toward a theory of sociotechnical change. Inside technology. Cambridge, Mass: MIT Press, 1995.

Bijker, Wiebe E., en John Law, (red.) Shaping technology/building society: studies in sociotechnical change. Inside technology. Cambridge, Mass.: MIT Press, 2010.

Boer, Theo A., Maarten J. Verkerk, en Dirk Jan Bakker. Over(-) behandelen: ethiek van de zorg voor kwetsbare ouderen. Amsterdam: Reed Business Education, 2013.

Boer, Theo A., en Dick Mul. Goede zorg, christelijk geïnspireerde ethiek van geval tot geval. Amsterdam: Buijten \& Schipperheijn Motief, 2013.

Borg, Meerten B. ter. Zineconomie: de samenleving van de overtreffende trap. Schiedam: Scriptum, 2003.

Borup, Mads, Nik Brown, Kornelia Konrad, en Harro Van Lente. 'The sociology of expectations in science and technology'. Technology Analysis \& Strategic Management 18, nr. 3-4 (2006): 285-98.

Boutellier, Hans. Het seculiere experiment: hoe we van God los gingen samenleven. Amsterdam: Boom, 2015.

Bouw, Matthijs. 'Architectuur en dominee, twee handen op een buik'. In Deus et machina: de verwevenheid van technologie en religie, Michiel van Well (red.), 404-13. Den Haag: STT, 2008.

Brom, Frans W. A. Thuis in de technologie (Inaugurele rede). Utrecht: Faculteit Geesteswetenschappen, Universiteit Utrecht, 2011.

Burgan, Michael, en Ted Hammond. Who is Richard Branson? New York: Grosset \& Dunlap, 2015. 
Burgelijk wetboek. Wet op de geneeskundige behandelingsovereenkomst, Pub. L. No. art. 7:445 BW (1994). https://wetten.overheid.nl/ BWBRoo05290/2020-09-01\#Boek7_Titeldeel7_Afdeling5.

Butterfield, Herbert. The whig interpretation of history. The Norton library 318. New York, NY: Norton, 1965.

Casanova, José. Public religions in the modern world. Chicago: University of Chicago Press, 1994.

-- - 'Rethinking secularization: a global comparative perspective'. In Religion, Globalization, and Culture, onder redactie van Peter Beyer en Lori Beaman, 101-20. Brill, 2007.

Centre for Ethics and Technology. '4TU.Ethics Centre for Ethics and Technology'. Geraadpleegd 28 september 2020.

https://ethicsandtechnology.eu/.

Cladis, Mark Sydney. 'Introduction'. In The elementary forms of religious life, door Émile Durkheim. Oxford world's classics. Oxford New York: Oxford University Press, 2001.

College voor de Rechten van de Mens. 'Universele verklaring van de rechten van de mens'. Geraadpleegd 28 september 2020. https:// mensenrechten.nl/nl/universele-verklaring-van-de-rechten-van-de-mens.

Collins, Harry M. Forms of life: the method and meaning of sociology. Cambridge, MA: The MIT Press, 2019.

Collins, Harry M., en Robert Evans. 'Probes, surveys, and the ontology of the social'. Journal of Mixed Methods Research 11, nr. 3 (juli 2017): 328-41.

Collins, Randall. Interaction ritual chains. Princeton University Press, 2014 .

Commissie Herziening Artseneed. Nederlandse artseneed. Utrecht: Vereniging van Universiteiten (VSNU), 2003.

Commissie Wetenschappelijk Onderzoek van het NHG. 'Woudschotenrapport: rapport over de taak van de huisarts, de zogenaamde Woudschotenmaterie.' Nederlands Huisartsen Genootschap, 1959. 
D'Adderio, Luciana. 'Artifacts at the centre of routines: performing the material turn in routines theory'. Journal of institutional economics 7, nr. 2 (2011): 197-230.

Dale, ... van, Ton den Boon, Dirk Geeraerts, en Nicoline van der Sijs. Groot woordenboek van de Nederlandse taal. 14'e, herz. uitg. / dr. Utrecht: Van Dale Lexicografie, 2005.

Dawkins, Richard. The God delusion. Boston, Mass.: Houghton Mifflin, 2006.

Dennett, Daniel C. Darwin's dangerous idea: evolution and the meanings of life. New York: Simon \& Schuster, 1995.

Digitale Bibliotheek voor de Nederlandse Letteren. 'Willem Kloos, Verzen'. DBNL. Geraadpleegd 11 september 2020. https://www.dbnl.org/ tekst/kloo003verz01_01/kloo003verz01_01_0005.php.

Donk, Wim van de, (red.) Geloven in het publieke domein: verkenningen van een dubbele transformatie. WRR verkenningen 13. Amsterdam: Amsterdam Univ. Press, 2006.

Dooyeweerd, Herman. Vernieuwing en bezinning; om het reformatorisch grondmotief. Zutphen: J.B. van den Brink, 1959.

Dosi, Giovanni., Christopher. Freeman, en Richard. Nelson. Technical change and economic theory. London: Pinter, 1988.

Douglas, Mary. Natural symbols: explorations in cosmology. Routledge Classics. London ; New York: Routledge, 2003.

-- . Purity and danger: an analysis of concepts of pollution and taboo. Routledge Classics. Milton: Routledge, 2003.

Durkheim, Émile. The division of labor in society. New York, N.Y.: The Free Press, 1997.

-- . The elementary forms of religious life. Oxford world's classics. Oxford New York: Oxford University Press, 2001.

DVN. 'Diabetes Vereniging Nederland'. Diabetesvereniging Nederland - Voluit leven met diabetes. Geraadpleegd 11 september 2020. https://www.dvn.nl/over-dvn. 
Edwards, Tony. 'Durkheim, Kant and the social construction of the categories'. In Reappraising Durkheim for the study and teaching of religion today, Thomas A. Idinopulos en Brian C. Wilson (red.), 73-83. Numen book series. Studies in the history of religions, v. 92. Leiden; Boston: Brill, 2002.

Ejizu, Christopher I. Readings on religion \& culture in Africa. Port Harcourt, Nigeria: M \& J Grand Orbit Communications, 2016.

Feldman, Martha S., Brian T. Pentland, Luciana D'Adderio, en Nathalie Lazaric. 'Beyond routines as things: introduction to the special issue on routine dynamics.' Organization Science 27, nr. 3 (2016): 505-13.

Ferry, Luc. Beginnen met filosofie: met andere ogen kijken naar je leven. Amsterdam: De Arbeiderspers, 2018.

Gerads, Rachel. De informatiepositie van de patiënt. Den Haag: Sdu Uitgevers, 2010.

Harmsen, Jan, en Maarten J. Verkerk. Process intensification: breakthrough in design, industrial innovation practices, and education. De Gruyter, 2020.

Harris, Sam. 'The case against faith.' Newsweek 148, nr. 20 (2006).

Hendel, Ronald. 'Mary Douglas and anthropological modernism'. Journal of Hebrew Scriptures 8 (2008): 2-10.

Hitchens, Christopher. 'Please, let's not do God.' New Statesman 138, nr. 4943 (2009).

Hoogland, Jan, en Henk Jochemsen. 'Professional autonomy and the normative structure of medical practice'. Theoretical medicine and bioethics 21, nr. 5 (2000): 457-75.

Houtman, Dick., en Birgit. Meyer. Things: religion and the question of materiality. The future of the religious past. New York: Fordham University Press, 2012.

Isaacson, Walter. Steve Jobs: de biografie, 2015. 
Jabaaij, Lea, Henk Schers, Ted van Essen, Lex Goudswaard, en François Schellevis. 'Altijd dezelfde huisarts? Een onderzoek naar wens en waardering van patiënten'. Huisarts en Wetenschap 49, nr. 13 (1 december 2006): 934-39.

Jasanoff, Sheila. Science at the bar: law, science, and technology in America. Cambridge, Mass.: Harvard University Press, 1995.

Jasanoff, Sheila. States of knowledge: the co-production of science and social order. London; New York: Routledge, 2004.

Jasanoff, Sheila., en Sang-Hyun Kim. Dreamscapes of modernity: sociotechnical imaginaries and the fabrication of power. Chicago ; The University of Chicago Press, 2015.

Joas, Hans. De macht van het heilige: een alternatief voor de geschiedenis van de onttovering. Rotterdam: Lemniscaat, 2018.

Johan Cruijff - MasterCard advertentie. Geraadpleegd 24 december 2020. https://www.youtube.com/watch?v=XAf37y4Wjh4.

Julius Centrum. 'Julius Centrum'. Achtergrond Julius Centrum. Geraadpleegd 21 september 2020. https://juliuscentrum.umcutrecht.nl/ nl-NL/over-julius-centrum/achtergrond.

Kenyatta, Jomo. Facing Mount Kenya: the traditional life of the Gikuyu. African writers series ; 219. London: Heinemann, 1979.

Klijn, Annemieke. Verlangen naar verbetering: 375 jaar academische geneeskunde in Utrecht. Amsterdam: Boom, 2010.

Knorr-Cetina, Karin, en Rom Harré. Die Fabrikation von Erkenntnis : zur Anthropologie der Naturwissenschaft. Theorie. Frankfurt am Main: Suhrkamp, 1984.

Kockelkoren, Petran. Techniek: kunst, kermis en theater. Fascinaties. Rotterdam: NAi Uitgevers, 2003.

KWF. 'Tegen kanker. Voor het leven. KWF Kankerbestrijding'. Geraadpleegd 11 september 2020. https://www.kwf.nl/. 
Lambek, Michael (red.), A reader in the anthropology of religion. Blackwell anthologies in social and cultural anthropology 2. Malden, Mass: Blackwell Publishers, 2002.

Latour, Bruno. Wij zijn nooit modern geweest: pleidooi voor een symmetrische antropologie. Amsterdam: Van Gennep, 1994.

Latour, Bruno, en Steve Woolgar. Laboratory life: the construction of scientific facts. Princeton, N.J.: Princeton University Press, 1986.

Law, John. 'Technology and heterogeneous engineering: the case of Portuguese expansion'. In The social construction of technological systems: new directions in the sociology and history of technology, Wiebe E. Bijker, Thomas P. Hughes, en Trevor. Pinch (red.), 111-34. Cambridge, Mass.: MIT Press, 2012.

Lemmers, Lex, en Jeroen de Greeff. Gezondheidsbevordering en leefstijl: een praktische inleiding. Amsterdam: Boom, 2018.

Lente, Dick van. 'Techniek \& ideologie: opvattingen over de maatschappelijke betekenis van technische vernieuwingen in Nederland, 1850-1920' (Proefschrift). Wolters-Noordhoff: Forsten, 1988.

Lente, Harro van. 'Promising technology: the dynamics of expectations in technological developments' (Proefschrift). Eburon, 1993.

Lente, Harro van, en Sjoerd Bakker. 'Competing expectations: the case of hydrogen storage technologies'. Technology Analysis \& Strategic Management 22, nr. 6 (2010): 693-709.

Lilla, Mark. The stillborn God: religion, politics, and the modern west. New York: Vintage Books, 2008.

Lim, Francis Khek Gee. Mediating piety: technology and religion in contemporary Asia. Social sciences in Asia, 1567-2794 ; v. 26. Leiden; Brill, 2009.

Lynch, Gordon. The sacred in the modern world: a cultural sociological approach. Oxford: Oxford University Press, 2014.

Marx, Karl. Zur Kritik der Hegelschen Rechtsphilosophie. BoD - Books on Demand, 2017. 
McGuire, Meredith B. Religion, the social context. 5th ed. Belmont, CA: Wadsworth Thomson Learning, 2002.

Merton, Robert King. Science, technology and society in seventeenth century England. Harvard classics. New York: H. Fertig, 1970.

Meyer, Birgit. 'Religious sensations: why media, aesthetics and power matter in the study of contemporary religion'. In Religion: beyond a concept, Hent de Vries (red.), 704-23. The future of the religious past. New York [NY]: Fordham University Press, 2008.

Montesquieu Instituut. 'De Nederlandse grondwet'. Geraadpleegd 28 september 2020. https://www.denederlandsegrondwet.nl/.

Mulder, Sjoerd. 'Moeten we wel naar mars?' Trouw, 19 juli 2019. https://www.trouw.nl/gs-b5e085c1.

Muller, F, E.H Renkema, en A.D Leeman. Wolters' handwoordenboek Latijn-Nederlands. Groningen: Wolters' Woordenboeken, 1995.

Munnik, René. 'Schriftreligies, technologisch gemedieerde religies?' In Deus et machina: de verwevenheid van technologie en religie, Michiel van Well (red.), 98-105. Den Haag: STT, 2008.

Nederlandse Zorgautoriteit. 'Tariefbeschikking TB/CU-7009-01'. NZa, 16 december 2010.

---. 'Zienswijze (openbare versie) Concentratie zorgverzekeraars Agis, Menzis en Delta Lloyd'. NZa, 1 oktober 2006.

Nelson, John K. Experimental Buddhism: innovation and activism in contemporary Japan. Topics in contemporary Buddhism. Honolulu: University of Hawai'i Press, 2014.

NICTIZ. 'EDIFACT’. Geraadpleegd 21 december 2020. https://www.nictiz.nl/standaarden/edifact/.

Nijenhuis, Johan. De beentjes van Sint-Hildegard. Comedy, Drama. Johan Nijenhuis \& Co, Nijenhuis \& Co, 2020.

Noble, David F. The religion of technology: the divinity of man and the spirit of invention. New York: Penguin Books, 1999. 
Ntarangwi, Mwenda. Reversed gaze: an African ethnography of American anthropology. Urbana: University of Illinois Press, 2010.

NTR. 'De seksuele moraal voor en na de pil'. Andere Tijden. Geraadpleegd 28 september 2020. https://www.anderetijden.nl/aflevering/ 558/De-seksuele-moraal-voor-en-na-de-pil\%2obekeken\%2od.d.

Nye, David E. American technological sublime. Cambridge, Mass. etc.: MIT Press, 1994.

Otto, Rudolf. Het heilige: over het irrationeele in de idee van het goddelijke en de verhouding ervan tot het rationeele. Amsterdam: Seyffardt's Boek- en Muziekhandel, 1928.

Oudshoorn, N. Telecare technologies and the transformation of healthcare. Health, technology and society. Basingstoke: Palgrave Macmillan, 2011.

'Over M\&ICT'. Geraadpleegd 15 september 2020. https://m-ict.nl/over-mict/.

Pärna, Karen. 'Believing in the net: implicit religion and the internet hype, 1994-2001' (Proefschrift). Leiden University Press, 2010.

'Patiëntenfederatie Nederland'. Geraadpleegd 16 september 2020. https://www.patientenfederatie.nl/.

PAZIO. 'PAZIO'. Geraadpleegd 25 september 2020. https://www.pazio.nl/.

Pentland, Brian T., en Martha S. Feldman. 'Designing routines: on the folly of designing artifacts, while hoping for patterns of action'. Information and Organization 18, nr. 4 (2008): 235-50.

Pharmeon. 'Pharmeon'. Geraadpleegd 23 december 2020. https://pharmeon.nl/.

Philips let's make things better ad 1994. Geraadpleegd 10 september 2020. https://www.youtube.com/watch?v=FWLoORHp2wk.

Price, Joseph L. Review of Review of the spiritual situation in our technical society, door Paul Tillich en J. Mark Thomas. The Journal of Religion 70, nr. 2 (1990): 264-264. 
Ritzer, George, en Douglas J. Goodman. Sociological theory. 6. ed. Boston: McGraw-Hill, 2004.

RVO. 'Pieken in de Delta subsidieregelingen'. Geraadpleegd 4 februari 2015. http://www.rvo.nl/subsidies-regelingen/pieken-de-delta.

Schot, J. W., red. Techniek in Nederland in de twintigste eeuw. Zutphen: Stichting Historie der Techniek : Walburg Pers, 1998.

Schouten, Matthijs G.C. Spiegel van de natuur: het natuurbeeld in cultuurhistorisch perspectief. Utrecht: KNNV Uitgeverij, 2005.

Schuurman, Egbert. Bevrijding van het technische wereldbeeld: uitdaging tot een andere ethiek. Delft: Technische Universiteit Delft, Faculteit Techniek, Bestuur en Management, 2002.

-- Geloven in wetenschap en techniek: hoop voor de toekomst. Verantwoording ; nr. 15. Amsterdam: Buijten \& Schipperheijn, 1998.

Schwarz, Michiel., en Rein. Jansma. De technologische cultuur. Amsterdam: De Balie, 1989.

Simpson, J. A., E. S. C. Weiner, en Donna Lee Berg, red. The compact Oxford English dictionary. 2nd ed. Oxford : New York: Clarendon Press ; Oxford University Press, 1991.

Smits, Martijntje. 'Monsterbezwering: de culturele domesticatie van nieuwe technologie' (Proefschrift). Boom, 2002.

Stichting Je leefstijl als medicijn. 'Stichting Je leefstijl als medicijn'. Geraadpleegd 21 september 2020. https://www.jeleefstijlalsmedicijn.nl/.

Stoep, Jan van der. 'Oecumene van het hart, Christelijke orthodoxie in een informatiesamenleving'. In Deus et machina: de verwevenheid van technologie en religie, Michiel van Well (red.), 106-11. Den Haag: STT, 2008 .

Swierstra, Tsjalling. Heracliteïsche ethiek: omgaan met de soft impacts van technologie (Inaugurele rede). Maastricht: Maastricht University, Faculty of Arts and Social Sciences, 2011. 
---. Kloneren in de polder het maatschappelijk debat over kloneren in Nederland, februari 1997 - oktober 1999. Den Haag: Rathenau instituut, 2000

Szerszynski, Bronislaw. Nature, technology, and the sacred. Religion and spirituality in the modern world. Malden, MA: Blackwell Pub, 2005.

Tangram Media. Promotiefilm PAZIO, 2010.

https://www.youtube.com/watch?v=4WOns9eqBK4.

'Tangram media, tegenwoordig Deltafilm'. Geraadpleegd 25 september 2020. http://www.tangrammedia.nl/.

Taylor, Charles. A secular age. Cambridge, MA: The Belknap Press of Harvard University Press, 2007.

Tweed, Thomas A. Crossing and dwelling: a theory of religion. Cambridge, MA: Harvard University Press, 2006.

United Nations. 'Sustainable development goals, 17 goals to transform our world'. Geraadpleegd 28 september 2020. https://www.un.org/sustainabledevelopment/.

Vance, Ashlee. Elon Musk: Tesla, SpaceX, and the quest for a fantastic future. ecco biography. New York, N.Y: Ecco, 2016.

Veer, Peter van der. 'Religie, technologie en communicatie'. In Deus et machina: de verwevenheid van technologie en religie, Michiel van Well (red.), 84-87. Den Haag: STT, 2008.

Verkerk, Maarten J. 'A philosophy-based "toolbox" for designing technology: The conceptual power of Dooyeweerdian philosophy'. Koers 79, nr. 3 (2014): 1-7.

-_- 'Trust and power on the shop floor: an ethnographical, ethical, and philosophical study on responsible behaviour in industrial organizations (Proefschrift).' Eburon Academic Publishers, 2005.

Verkerk, Maarten J., Fred C. Holtkamp, Eveline J.M. Wouters, en Joost van Hoof. 'Professional practices and user practices: an explorative study in health care'. Philosophia Reformata 82, nr. 2 (2017): 167-91. 
Verkerk, Maarten J., Jan van der Stoep, Jan Hoogland, en Marc J. de Vries. Denken, ontwerpen, maken: basisboek techniekfilosofie. Amsterdam: Boom, 2007.

Vries, Gerard de, Klasien Horstman, en Olga Haveman. Politiek van preventie: normatieve aspecten van voorspellende geneeskunde. Den Haag: Rathenau instituut, 1997.

Vries, Hent de, en Samuel Weber (red.), Religion and media. Cultural memory in the present. Stanford, Calif: Stanford University Press, 2001.

Vries, Marc J. de, en Henk Jochemsen, red. The normative nature of social practices and ethics in professional environments. Hershey, PA: IGI Global, Information Science Reference, 2019.

Walsh, David. 'Doing ethnography'. In Researching society and culture, onder redactie van Clive Seale, 2nd ed., 225-38. London; Thousand Oaks, Calif: Sage Publications, 2004.

‘Wat is DigiD?’ Geraadpleegd 25 september 2020. https://www.digid.nl/wat-is-digid.

Weber, Max. Wissenschaft als Beruf: 1917 - 1919; Politik als Beruf: 1919. Mohr Siebeck, 1992.

Well, Herman H. van. (in voorbereiding) Kerk blijf in de buurt! De samenhang van kerk en wijk. Amsterdam: Buijten \& Schipperheijn.

- - - (in voorbereiding) 'Zien en gezien worden. Diaconale presentie en diaconale actie door drie interculturele kerken in de Tarwewijk op Rotterdam-Zuid' (Proefschrift). Amsterdam: Buijten \& Schipperheijn.

Well, Michiel D.J. van. 'Another inconvenient truth, interview met Wim van der Donk'. In Deus et machina: de verwevenheid van technologie en religie, 72-76. Den Haag: STT, 2008.

Werf, Ger van der, en Joost Zaat. 'De geboorte van een ideologie: Woudschoten en de huisartsgeneeskunde'. Huisarts en Wetenschap 44, nr. 10 (2001): 281-89.

Wetenschappelijke Raad voor het Regeringsbeleid. Weten is nog geen doen: een realistisch perspectief op redzaamheid. WRR-Rapport ; nr. 97. Den Haag: WRR, 2017. 
Wikipedia. 'Catechismus'. Geraadpleegd 21 december 2020. https://nl.wikipedia.org/wiki/Catechismus.

Winner, Langdon. 'Do artifacts have politics?' Daedalus 109, nr. 1 (1980): 121-36.

-_- 'Upon opening the black box and finding it empty: social constructivism and the philosophy of technology'. Science, Technology, \& Human Values 18, nr. 3 (1993): 362-78.

Wit, Niek de. Huisartsgeneeskunde: van alledaagse romantiek naar academische praktijk (Inaugurele rede). Utrecht: UMC Utrecht, 2010.

Wolfe, Alan. 'An introduction to American religious practice'. In Geloven in het publieke domein: verkenningen van een dubbele transformatie, Wim van de Donk (red.), 209-24. WRR verkenningen 13. Amsterdam: Amsterdam Univ. Press, 2006.

Zandbergen, Dorien. 'New edge: technology and spirituality in the San Francisco bay area' (Proefschrift). Universiteit Leiden, 2011. 



\section{EMPIRISCH MATERIAAL PAZIO}

FORMAT: AUTEUR. TITEL. SOORT BESTAND, DATUM.

Brekel, Karolien van den. PAZIO e-consult stand van zaken. E-mail, 3 juni 2010.

Business Team PAZIO. Definitiestudie PAZIO. Tekstdocument, 16 juni 2008.

Dekker, André. Programma en presentatie voor derde klantenpanelbijeenkomst. Diapresentatie, 4 februari 2009.

-- Programma en presentatie voor tweede klantenpanelbijeenkomst. Diapresentatie, 17 december 2008.

-- . Programma en presentatie voor vierde klantenpanelbijeenkomst. Diapresentatie, 8 juli 2009.

--D. Programma en presentatie voor vijfde klantenpanelbijeenkomst. Diapresentatie, 29 september 2010.

-- . Verslag bespreking PAZIO 9 oktober 2007. Tekstdocument, 9 oktober 2007.

Dekker, André, en Hero Torenbeek. Programmaopzet PAZIO. Tekstdocument, 27 november 2007.

Dekker, Marianne, en Marc Rietveld. Plan van aanpak Implementatie pilot PAZIO bij LRJG. Tekstdocument, 17 november 2009.

Economic Board Utrecht. PAZIO introductie. Film, 2013. https://www.youtube.com/watch?v=CAgBvoCzWdw\&t=83s.

Flikweert, Leone. Patiëntencommunciatie Julius Online. Tekstdocument, 10 mei 2011. 
Julius Centrum. Achtergrond Julius Centrum. Website, Geraadpleegd 21 september 2020. https://juliuscentrum.umcutrecht.nl/nl-NL/ over-julius-centrum/achtergrond.

Kuilboer, Jos. Persoonlijke uitnodiging PAZIO Kick off. Tekstdocument, 4 januari 2010.

--_. Programma PAZIO Kick off. Tekstdocument, 11 februari 2010.

Lange, Mark de. Presentatie voor de PAZIO-stuurgroep.

Diapresentatie, 2 oktober 2008.

LRGP. Leidsche Rijn Gezondheidsproject. Website, Geraadpleegd 11 september 2020. http://www.lrgp.nl/.

LRJG. LRJG magazine. Tekstdocument, 2018.

--C. Missie en visie LRJG. Website, Geraadpleegd 1 december 2020. https://parkwijk.lrjg.nl/leidsche-rijn-julius-gezondheidscentra/.

NPCF. Positionering Mijn Zorg Online. Tekstdocument, 15 mei 2009.

Oomes, Jan, en Niek de Wit. Jaarverslag 2012 Leidsche Rijn Julius Gezondheidscentra. Tekstdocument, 2012.

Osch, Marieke van. Genodigdenlijst kick off. Tekstdocument, 2 januari 2010.

--- Notulen werkbespreking PAZIO d.d.13 januari 2011.

Tekstdocument, 13 januari 2011.

M\&ICT. Over M\&ICT. Website, Geraadpleegd 15 september 2020. https://m-ict.nl/over-mict/.

PAZIO. Addendum behorende bij PAZIO Programmaopzet en Convenant. Tekstdocument, 2 oktober 2008.

-- . Concept projectvoorstel PAZIO voor M\&ICT. Tekstdocument, mei 2007.

-- Convenant voor samenwerking ontwikkeling landelijk gezondheidsportaal PAZIO. Tekstdocument, 23 februari 2008. 
-- Icoon Consult Online. Afbeelding, 2011

---. Icoon Julius Online. Afbeelding, 2011.

-_-. PAZIO. Website, Geraadpleegd 25 september 2020.

https://www.pazio.nl/.

---. PAZIO Animatie 2019. Film, 25 juni 2019.

https://www.youtube.com/watch?v=rzRLzZ_XVUc\&feature=emb_logo.

---. PAZIO leaflets voor doelgroepen. Tekstdocument, 11 februari 2009 .

-_-. PAZIO presentatie algemeen. Diapresentatie, 11 februari 2009.

PAZIO, en PharmaPartners. Gezamelijke visie patiëntenportalen. Tekstdocument, 1 februari 2010.

--C. Samenwerkingsovereenkomst PAZIO - PharmaPartners.

Tekstdocument, 26 april 2010.

Pharmeon. Pharmeon. Website, Geraadpleegd 23 december 2020. https://pharmeon.nl/.

Redekker, Leni. Verslag PAZIO stuurgroepvergadering 23 juni 2008. Tekstdocument, 23 juni 2008.

Rietveld, Marc. Concept ontwikkeling PVZ. Tekstdocument, 26 juni 2007.

Rietveld, Marc, en Mediportaal. Voorstel "Patiëntgeoriënteerde Virtuele Zorginfrastructuur”. Tekstdocument, 9 november 2006.

Roemer, Nynke. Notulen werkoverleg PAZIO@LRJG.VW d.d. o1 maart 2011. Tekstdocument, 1 maart 2011.

---. Notulen werkoverleg PAZIO@LRJG.VW. d.d. o8 februari 2011. Tekstdocument, 8 februari 2011.

RVO. Pieken in de Delta subsidieregelingen. Website, Geraadpleegd 4 februari 2015. http://www.rvo.nl/subsidies-regelingen/pieken-de-delta. 
Tangram Media. Promotiefilm PAZIO. Film, 2010. https://www.youtube.com/watch?v=4WOns9eqBK4.

--C. Script film PAZIO. Tekstdocument, 13 januari 2010.

UMCU, Mediportaal, VitalHealth Software, VitaValley, LRJG, Imtech, en UT. Projectplan PAZIO (bijlage A bij Pieken in de Delta aanvraag). Tekstdocument, 9 mei 2009.

VitaValley. Identiteitsstatuut VitaValley. Tekstdocument, 3 mei 2010.

---. Lobby PAZIO - doel en opzet. Tekstdocument, oktober 2008.

-- . Verslag van de tweede bijeenkomst Portaalring. Tekstdocument, 18 mei 2010.

VitaValley, en NPCF. Startnotitie Portaalring. Tekstdocument, oktober 2009.

Well, Michiel van. Aanvulling bij revitaliseringsplan PAZIO@LRJG. Tekstdocument, 3 maart 2011.

---. Evaluatie van de implementatie PAZIO binnen het LRJG. Tekstdocument, 16 juni 2010.

-_-. PAZIO-logboek april 2010. Tekstdocument, april 2010.

-_-. PAZIO-logboek april 2011. Tekstdocument, april 2011.

-_-. PAZIO-logboek augustus 2010. Tekstdocument, augustus 2010.

-_-. PAZIO-logboek december 2010. Tekstdocument, december 2010.

---. PAZIO-logboek februari 2011. Tekstdocument, februari 2011.

-_- PAZIO-logboek februari-maart 2010. Tekstdocument, februari 2010.

-_-. PAZIO-Logboek januari 2011. Tekstdocument, januari 2011.

-_-. PAZIO-logboek juli 2010. Tekstdocument, juli 2010.

-_-. PAZIO-logboek juni 2010. Tekstdocument, juni 2010. 
---. PAZIO-logboek maart 2011. Tekstdocument, maart 2011.

--_. PAZIO-logboek mei 2010. Tekstdocument, mei 2010.

-_-. PAZIO-logboek mei 2011. Tekstdocument, mei 2011.

-_-. PAZIO-logboek november 2010. Tekstdocument, november 2010

--_. PAZIO-logboek oktober 2010. Tekstdocument, oktober 2010

--D. PAZIO-logboek september 2010. Tekstdocument, september 2010 .

Wind, Lidewij. PAZIO. E-mail, 12 januari 2010.

Witte, Jan. Verslag PAZIO-stuurgroepvergadering 02 oktober 2008. Tekstdocument, 2 oktober 2008.

--C. Verslag PAZIO-stuurgroepvergadering 05 januari 2009. Tekstdocument, 5 januari 2009.

---. Verslag PAZIO-stuurgroepvergadering 26 februari 2009. Tekstdocument, 26 februari 2009.

---. Verslag PAZIO-stuurgroepvergadering 26 november 2007. Tekstdocument, 26 november 2007. 



\section{AFKORTINGEN}

AIS

EZ

CVZ

DNS

DZM

EDIFACT

GGZ

HIS

ICPC

ICT

KNMG

LRJG

LRGP

MGn

NHG

NICTIZ

NIPED

NPCF

PHIS

$\mathrm{POH}$

PVZ

PAZIO

RSG

SCOT

STC

TIM

UMCU

VHS

VWS

WGBO
Apothekersinformatiesysteem

(ministerie van) Economische Zaken

College voor Zorgverzekeringen

Domain Name System

Diabetes Zelfmanagement

Electronic Data Interchange For Administration,

Commerce and Transport

Geestelijke Gezondheidszorg

Huisartsinformatiesysteem

International Classification of Primary Care

Informatie- en Communicatietechnologie

Koninklijk Nederlands Medisch Genootschap

Leidsche Rijn Julius Gezondheidscentra

Leidsche Rijn Gezondheidsproject

MijnGezondheid.net

Nederlands Huisartsen Genootschap

Nederlands Instituut voor ICT in de Zorg

Netherlands Institute for Prevention and e-Health

Development

Nederlandse Patiënten- en Consumenten Federatie

Personal Health Information System

Praktijkondersteuner Huisarts

Patiëntgebonden Virtuele Zorginfrastructuur

Patiëntgeoriënteerde Zorginformatie Omgeving

Relevante Sociale Groep

Social Construction of Technology

(Theorie van het) Sacrale in een Technologische

Cultuur

Triple I Model

Universitair Medisch Centrum Utrecht

VitalHealth Software

(ministerie van) Volksgezondheid, Welzijn en Sport

Wet op de geneeskundige behandelingsovereenkomst 



\section{FIGUREN EN TABELLEN}

Figuur 2.1 Grondmotieven als het wortelgestel van een boom.

Tabel 2.1 Schematisch overzicht van de perioden van the Long Arc. 51

Tabel 2.2 Modaliteiten van Dooyeweerd. 59

Figuur 2.2 Schematische weergave van het Triple I model. $\quad 62$

Figuur 3.1 PAZIO logo en pay off. $\quad 97$

Figuur 3.2 Schema voor het PVZ. 103

$\begin{array}{lll}\text { Figuur 3.3 De veranderende positie van de gebruiker. } & 104\end{array}$

Figuur 3.4 Geïntegreerde informatie- en applicatieinfrastructuur. 108

Figuur 3.5 Structuur en planning van het project PAZIO.

Figuur 3.6 PAZIO-logo.

Figuur 3.7 Architectuurschets PAZIO. 122

Tabel 3.1 Besproken subsidieprogramma's en regelingen voor PAZIO. 129

Figuur 3.8 Het PAZIO-concept. $\quad 135$

Figuur 4.1 Stoplichtmatrix uit de evaluatie van de PAZIO-implementatie bij LRJG.

Figuur 4.2 HIS-integratiescenario. 176

$\begin{array}{lll}\text { Figuur 4.3 Portaal-integratiescenario. } & \mathbf{1 7 7}\end{array}$

Figuur 4.4 Icoon Julius Online. 181

Figuur 4.5 Icoon Consult Online. 181

Tabel 5.1 Perspectieven op het PVZ van relevante sociale groepen en hun identiteit. $\quad \mathbf{2 0 8}$

Figuur 5.1 Beoogde leveranciers en afnemers van het PVZ. 209

Figuur $\mathbf{5 . 2}$ Stakeholderbelangen. $\mathbf{2 1 2}$

Tabel 6.1 Vergelijking SCOT en Durkheims theorie van het sacrale. 246

Figuur $\mathbf{6 . 1}$ Sociaal-sacrale dynamiek. $\quad \mathbf{2 4 8}$

Figuur 6.2 Narratief-sacrale dynamiek. 250

Figuur 6.3 Activiteiten-sacrale dynamiek. 253

Figuur 6.4 Sacrale vorm. $\quad 256$

Figuur 6.5 Stabilisering. $\quad 258$

Figuur 6.6 Verandering. $\quad 260$

Figuur 6.7 Theorie voor het Sacrale in een

Technologische Cultuur (STC).

Tabel 6.2 Dichotomieën voor onderzoek. 263 




\section{DANKWOORD}

\section{'Anthropology begins at home' is as true of Africa as of Europe.}

\section{Bronislaw Malinowski ${ }^{1}$}

'Het is allemaal gegeven'. Met die doorleefde uitspraak plaatste mijn oma Van Well resultaten graag in het juiste perspectief. Ze had helemaal gelijk. Ook dit proefschrift had ik zonder de gegeven hulp van vele anderen niet tot een goed eind had kunnen brengen.

Mijn bijzondere dank gaat uit naar mijn promotoren Maarten Verkerk en Wiebe Bijker. Ik prijs me gelukkig met de manier waarop ik met jullie mocht samenwerken. Ik kan me niet herinneren dat we ooit over regels, formaliteiten of organisatorische kwesties hebben gesproken. We zijn met elkaar begonnen vanuit een gedeelde inhoudelijke belangstelling en met vertrouwen in elkaar. Dat we zo vanzelfsprekend konden samenwerken, heb ik als bijzonder waardevol ervaren.

Wiebe, op een terras in Maastricht gaf je me ooit het duwtje in de rug dat ik nodig had om het onontgonnen terrein van technologie en religie te verkennen. Je was voor mij een leermeester, zoals ik er zelf één zou willen zijn. Je inhoudelijke zorgvuldigheid, de academische ruimte die je me gaf en je persoonlijke betrokkenheid heb ik zeer gewaardeerd.

Maarten, na onze kennismaking bij STT creëerde jij bij VitaValley een plek voor mij om empirisch onderzoek te doen naar technologie en religie en bood me tegelijkertijd de mogelijkheid te werken aan waardevolle zorginnovatie. Je gaf me daarmee veel vertrouwen. Bij VitaValley nam je steeds uitgebreid de tijd om met me te filosoferen over zorginnovatie, PAZIO en Dooyeweerd. Ik heb daarvan veel geleerd en genoten. 
Hartelijk dank aan de leden van de beoordelingscommissie, de hoogleraren Rein de Wilde, Birgit Meyer, Jan Hoogland, Sally Wyatt en Tsjalling Swierstra, voor hun bereidheid om mijn proefschrift van hun oordeel te voorzien.

Veel mensen hebben bijgedragen aan mijn opleiding en vorming, meer dan ik kan noemen. Ik ben dankbaar dat ik na mijn studie Chemie aan de Universiteit Utrecht de gelegenheid kreeg om bij de vakgroep Wetenschaps- en technologiedynamica aan de Universiteit van Amsterdam verder te studeren. De gevarieerde en open academisch cultuur gaf mij de ruimte om nieuwe richtingen in te slaan. Ik ben bijzondere dank verschuldigd aan Stuart Blume, die mij als net afgestudeerde bèta, introduceerde in het wetenschaps- en technologieonderzoek. Veel dank ook aan Willem Halffman en Ingrid Geesink met wie ik mijn ontdekkingstocht door de wondere wereld van Wetenschapsdynamica vanaf het begin heb afgelegd. Het bleek het begin van een prachtige vriendschap.

Graag bedank ik ook de mensen die mij bij verschillende organisaties de ruimte gaven om mee te werken aan de ontwikkeling van PAZIO en onderzoek te doen naar diezelfde ontwikkeling. Mark de Lange ben ik zeer erkentelijk dat hij me de mogelijkheid bood om mijn werk bij Vital Innovators te combineren met dit onderzoek.

Jos Kuilboer, André Dekker en Leone Flikweert dank ik voor de onvoorwaardelijke toegang die ze me gaven tot de keuken van PAZIO en de steun voor mijn onderzoek naar de ontwikkeling van PAZIO. Ik ben LRJG zeer erkentelijk voor hun gastvrijheid en de fijne samenwerking met Niek de Wit, Nynke Roemer, Tjerk Schuurman en Virginia Straal in het implementatieteam. Henk van der Tas van Beteor wil ik graag bedanken voor het mij bijbrengen van de fijne kneepjes van het verandervak en voor zijn warme betrokkenheid.

Graag spreek ik mijn dank uit aan Paul Baan en Wim Post. Vanuit de Noaber Foundation gaven ze niet alleen materiële steun voor dit onderzoek maar toonden er ook hun blijvende belangstelling voor.

Tineke Verhoeff - Van der Jagt, Hannah Dijkema - Den Besten en Marvin Imhof dank ik hartelijk voor het prachtig vormgeven van de sacrale vorm en het boek.

Ik wil ook mijn familie en vrienden bedanken. Ik heb jullie belangstelling voor het proefschrift en de broodnodige afleiding daarvan heel fijn gevonden. 
Hartelijk dank aan mijn paranimfen Eelco Weijland en Wolter Buijs dat ze mij op het moment suprême willen bijstaan. Het is mooi om hier samen met jullie te staan, nadat we van childhood's end af met elkaar optrokken langs tafeltennistafels, kerkbanken, surfwater en langs alles wat daarna kwam.

Ik ben dankbaar dat mijn ouders, Herman en Aline van Well, me stimuleerden om mijn talenten te ontdekken en benutten. Bovenal ben ik dankbaar voor de liefde die jullie me gaven. Daarmee kon ik de wereld in, bijvoorbeeld om dit proefschrift te schrijven.

Dank ook aan mijn schoonouders, Kees en Dirma van Grootheest, voor jullie belangstelling, meelezen en subtiele stimulans om dit proefschrift ook af te ronden. Het is bij jullie goed thuiskomen.

Lieve Liesbeth, dit proefschrift was niet alleen voor mij een uitdaging. Je hebt me altijd steun en ruimte gegeven, terwijl ik veel te lang heb gedacht en gezegd dat het bijna af was. Dit proefschrift was er zonder jou niet gekomen en is dankzij jou ook nog eens een stuk leesbaarder geworden. Ik ben blij dat je er bent.

Lieve Enan en lieve Amaris, jullie hebben mijn wereld groter gemaakt en laten me iedere dag ervaren wat waardevol, om niet te zeggen sacraal, is in het leven. Het is fijn, dat wij vieren samen zijn!

Het is allemaal gegeven.

Godzijdank. 



\section{CURRICULUM VITAE}

Michiel van Well werd op 12 december 1969 geboren in Rozenburg. $\mathrm{Na}$ het afronden van de middelbare school studeerde hij Chemie aan de Universiteit Utrecht (1989-1995). Vervolgens studeerde hij Wetenschapsen Technologiedynamica aan de Universiteit van Amsterdam (1994-1996). Hier vervulde hij ook zijn vervangende dienstplicht.

Michiel was van 1996 tot 2001 in dienst bij het Rathenau instituut als programmamedewerker Biomedische Technologie. Hij werkte daar onder meer aan het maatschappelijk debat over kloneren en aan projecten over voorspellende geneeskunde en voortplantingstechnologie. $\mathrm{Na}$ een uitstapje als redacteur bij de Ikon/Human Factor voor het televisieprogramma Jacobine, werkte hij van 2002 tot 2009 bij de Stichting Toekomstbeeld der Techniek. Hij was daar projectleider voor de verkenningen: Beter bouwen en bewonen en Deus et Machina - de verwevenheid van technologie en religie.

In de periode van 2009-2012 woonde Michiel met zijn echtgenote Liesbeth twee keer negen maanden in Nairobi om daar met Enan (2006) en Amaris (2009) een gezin te vormen.

Van 2010 tot 2018 werkte Michiel als health innovator bij Vital Innovators/VitaValley. Hij werkte onder meer aan de ontwikkeling en implementatie van het gezondheidsportaal PAZIO. In die tijd startte hij ook zijn promotieonderzoek als buitenpromovendus aan de Universiteit Maastricht. Vanuit Vital Innovators werd hij gedetacheerd bij het Rathenau instituut (2016) en de Wetenschappelijke Raad voor het Regeringsbeleid (2017). In 2018 maakte hij de overstap naar de Adviesraad voor Wetenschap, Technologie en Innovatie. Daar werkte hij als seniorraadsadviseur aan adviezen over de rol van wetenschap, technologie en innovatie in transities en over de ontwikkeling van sleuteltechnologieën.

Sinds 2020 werkt Michiel als senior-beleidsmedewerker bij het beleidsteam Privacy van het Ministerie van Justitie en Veiligheid en als onderzoeker aan de Christelijke Hogeschool Ede aan de ontwikkeling van een onderzoeksprogramma bij de ICT-opleiding. 


\section{Colofon}

Michiel van Well

Religie in een technologische cultuur

Over de rol van het sacrale in de ontwikkeling van het gezondheidsportaal PAZIO

ISBN 978-90-9035095-0

Omslag ontwerp en vormgeving: TinekeWerkt

Druk: Print.com

(๖ 2021, Michiel van Well

Uitgegeven in eigen beheer

Alle rechten voorbehouden.

Niets uit deze uitgave mag worden

verveelvoudigd, opgeslagen in een

geautomatiseerd gegevensbestand en/of

openbaar gemaakt in enige vorm of op enige

wijze, hetzij elektronisch, mechanisch, door

fotokopieën, opnamen of op enige andere

manier zonder voorafgaande schriftelijke

toestemming van de uitgever. 